\title{
Expression and function of serotonin receptor isoforms in the respiratory system
}

\author{
PhD Thesis \\ In partial fulfilment of the requirements for the degree of \\ Doctor of Philosophy (PhD)/Dr.rer.nat. \\ in the Graduate Programme Neurosciences at the \\ Georg-August University of Göttingen, \\ Faculty of Biology
}

submitted by

Till Manzke

born in

Goslar, Germany

Göttingen 2004 
Advisor, first member of FAC: Second member of FAC: Third member of FAC:
Prof. Dr. Diethelm W. Richter Prof. Dr. Erwin Neher Prof. Dr. Willhart Knepel

Date of submission of the PhD thesis: $13^{\text {th }}$ December 2004

Day of thesis defense (disputation): $24^{\text {th }}$ January 2005

Grade: 'summa cum laude` 
Herewith I declare that I prepared the PhD thesis

'Expression and function of serotonin receptor isoforms in the respiratory system' on my own and with no other sources and aids than quoted.

Göttingen, $13^{\text {th }}$ December 2004

Till Manzke 


\section{Contents}

\section{Summary}

\section{Abbreviations}

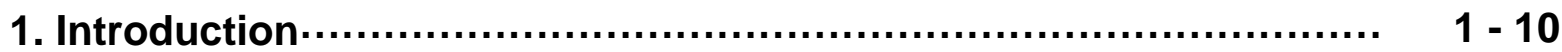

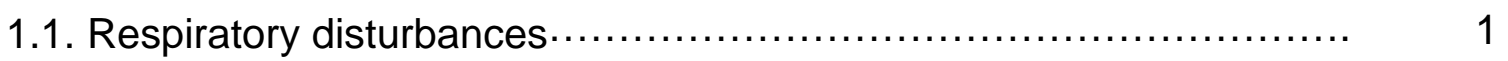

1.2. Localisation and function of the preBötzinger complex (PBC) $\ldots \ldots \ldots \ldots$.

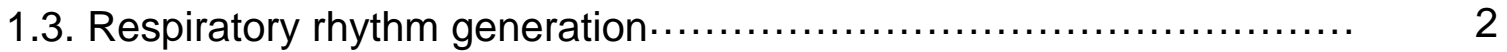

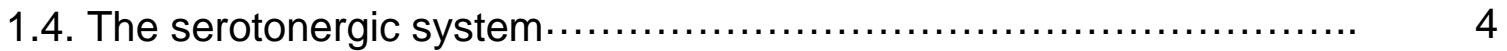

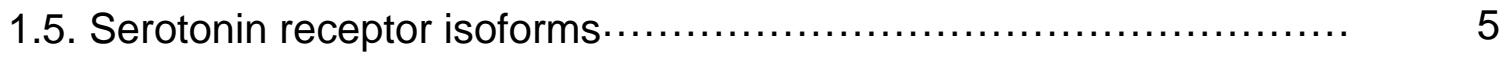

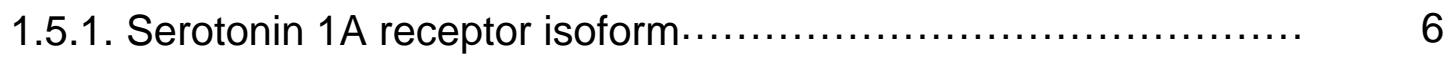

1.5.2. Serotonin $2 A$ and $2 B$ receptor isoforms $\ldots \ldots \ldots \ldots \ldots \ldots \ldots \ldots \ldots \ldots \ldots$

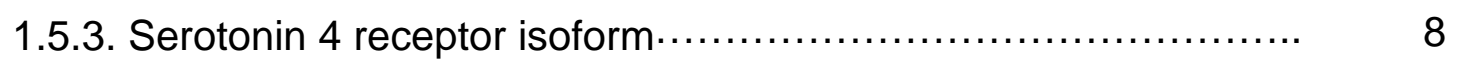

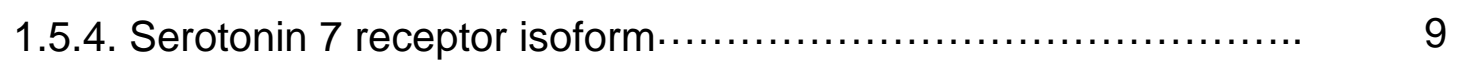

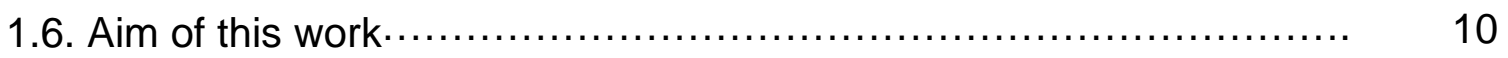

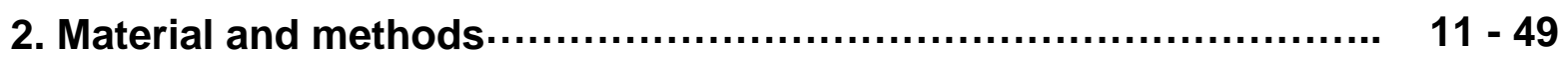

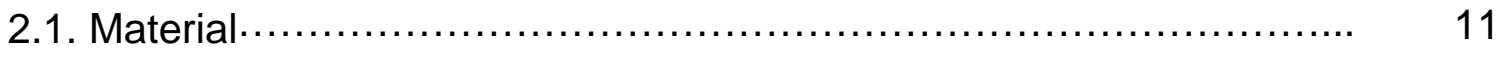

2.1.1. Reagents and chemicals $\ldots \ldots \ldots \ldots \ldots \ldots \ldots \ldots \ldots \ldots \ldots \ldots \ldots \ldots, 11$

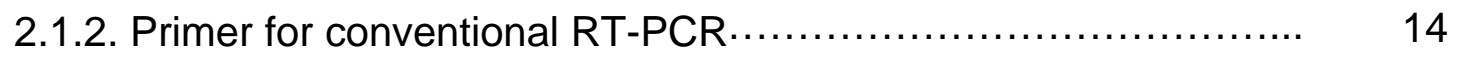

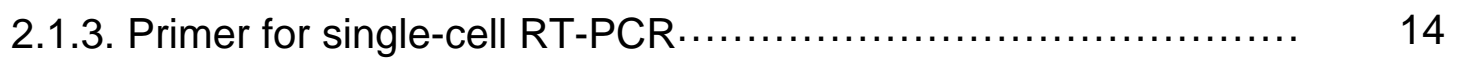

2.1.4. Peptides for immunisation $\ldots \ldots \ldots \ldots \ldots \ldots \ldots \ldots \ldots \ldots \ldots \ldots \ldots \ldots \ldots, 15$

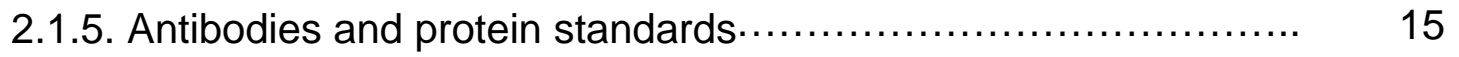

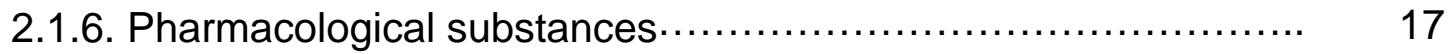

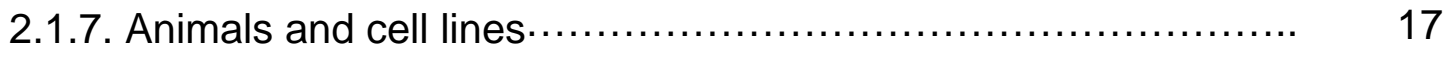

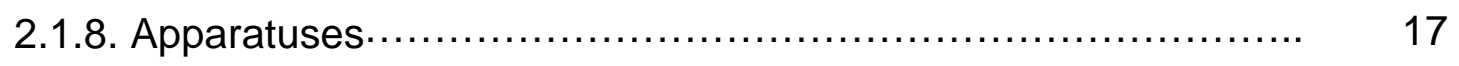




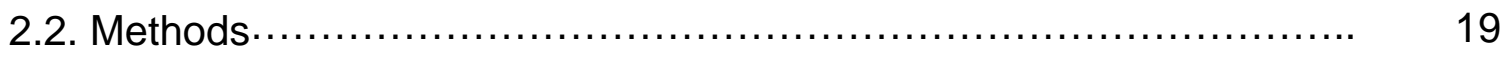

2.2.1. Production of poly- and monoclonal antibodies.................. 19

2.2.1.1. Theory of poly- and monoclonal antibodies................. 19

2.2.1.1.1. Polyclonal antibodies ............................... 19

2.2.1.1.2. Monoclonal antibodies ................................ 19

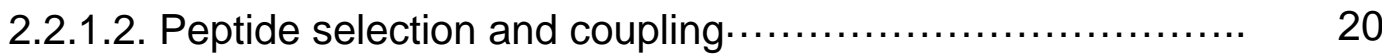

2.2.1.3. Immunisation and serum preparation ...................... 21

2.2.1.4. Determination of the antibody titre using an ELISA with solid phase-coated antigen .................... 22

2.2.1.5. Purification of polyclonal lgG by affinity chromatography on protein A-sepharose ('low-salt' method) .......... 23

2.2.1.6. Production of monospecific polyclonal IgG antibodies by affinity chromatography on CNBr-activated Sepharose ${ }^{\circledR} 4 B \quad 24$

2.2.1.7. Hybridisation, cloning, and screening of hybridomas......... 26

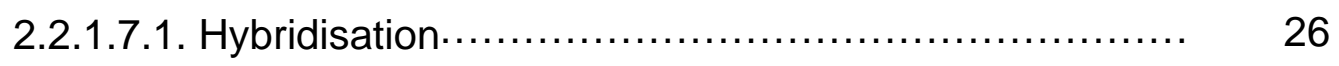

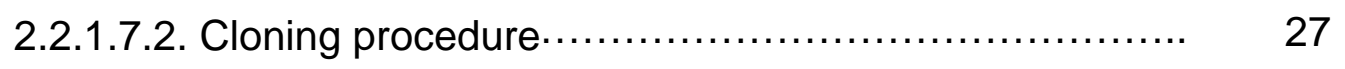

2.2.1.8. Isotype-characterisation of $\mathrm{mAb}$ using sandwich

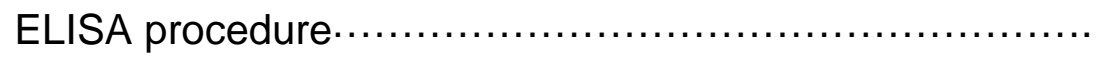

2.2.1.9. Purification of monoclonal IgG by affinity chromatography on protein A-sepharose ('high-salt' method) ................ 28

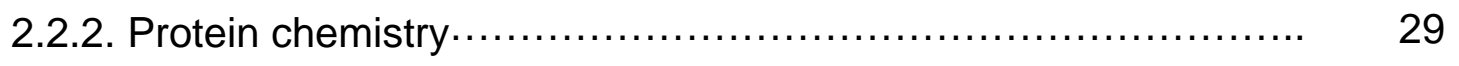

2.2.2.1. Solubilisation of proteins with Triton $X-100 \ldots \ldots \ldots \ldots \ldots \ldots \ldots . \quad 29$

2.2.2.2. Estimating total protein concentration according to Lowry... 29

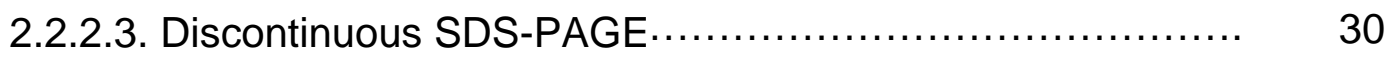

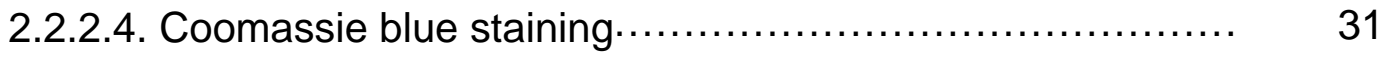

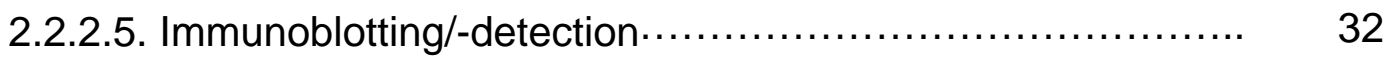

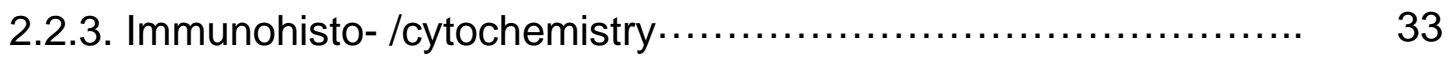

2.2.3.1. Preparation of brain tissue for immunohistochemistry $\ldots \ldots \ldots . \quad 33$

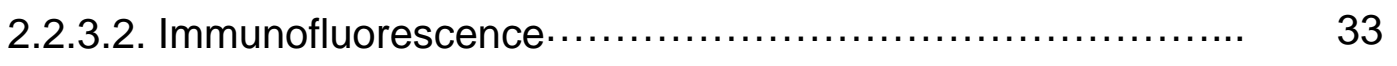

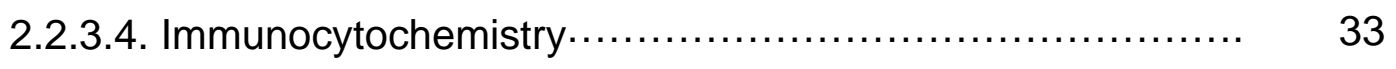


2.2.3.5. Confocal laser-scanning microscopy (CLSM) ............... 34

2.2.3.6. Peroxidase anti-peroxidase (PAP) and

(strept) avidin-biotin-complex (ABC) staining $\ldots \ldots \ldots \ldots \ldots \ldots . \quad 35$

2.2.4. Fluorescence-activated cell sorter (FACS), 'flow cytometry ‘..... 37

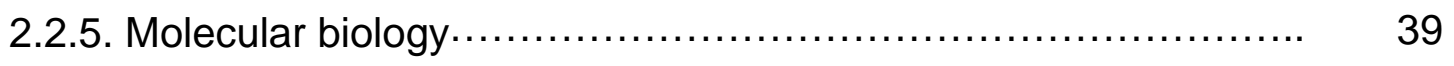

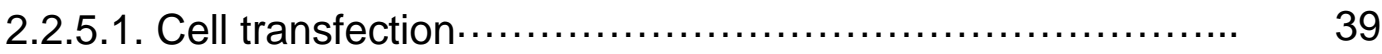

2.2.5.2. Reverse transcriptase-polymerase chain reaction

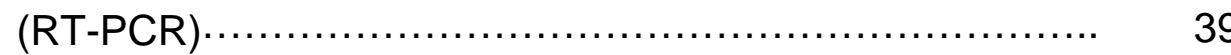

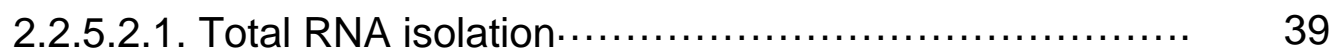

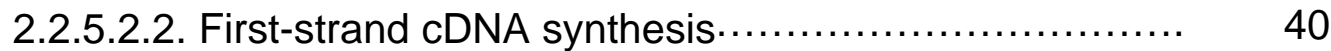

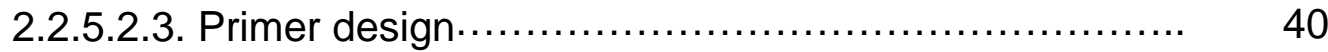

2.2.5.2.4. Polymerase chain reaction (PCR) $\ldots \ldots \ldots \ldots \ldots \ldots \ldots \ldots \ldots \ldots \ldots$

2.2.5.2.5. Single-cell RT-PCR on identified respiratory neurones 41

2.2.5.6. Separation of DNA fragments on standard

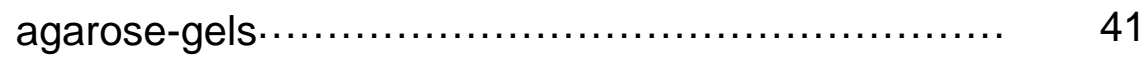

2.2.5.2.7. DNA isolation and quantification $\ldots \ldots \ldots \ldots \ldots \ldots \ldots \ldots \ldots, 42$

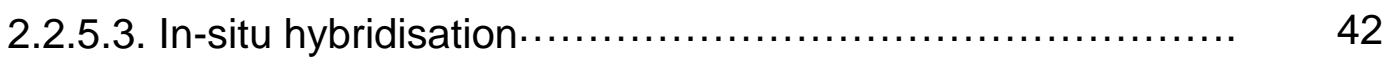

2.2.5.3.1. Subcloning of DNA fragments $\ldots \ldots \ldots \ldots \ldots \ldots \ldots \ldots \ldots, 43$

2.2.5.3.1.1. Dephosphorylation of the plasmid $\ldots \ldots \ldots \ldots \ldots \ldots \ldots . . . .43$

2.2.5.3.1.2. Preparation of the DNA fragment $\ldots \ldots \ldots \ldots \ldots \ldots \ldots . . . \ldots 4$

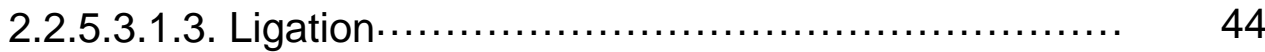

2.2.5.3.1.4. Preparation of competent cells $\ldots \ldots \ldots \ldots \ldots \ldots \ldots \ldots \ldots \ldots$

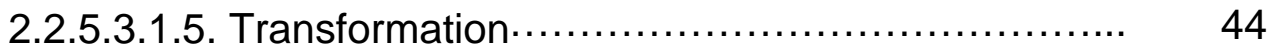

2.2.5.3.2. Isolation of the plasmid-DNA with TELT-buffer.......... 44

2.2.5.3.3. Non-radioactive labelling of RNA probes

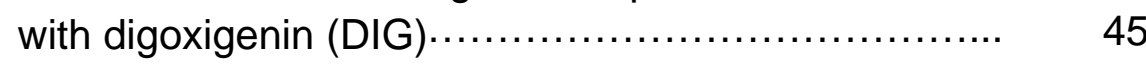

2.2.5.3.4. Non-radioactive detection with AP-conjugated anti-DIG antibodies $\ldots \ldots \ldots \ldots \ldots \ldots \ldots \ldots \ldots \ldots \ldots \ldots \ldots, \quad 45$

2.2.5.3.5. In-situ hybridisation on paraffin sections $\ldots \ldots \ldots \ldots \ldots \ldots . \quad 46$ 


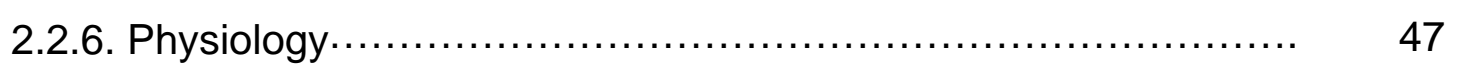

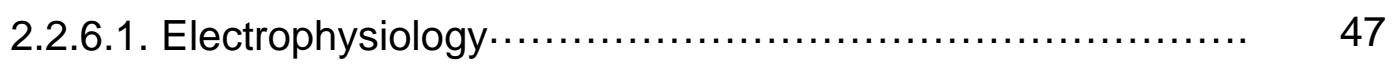

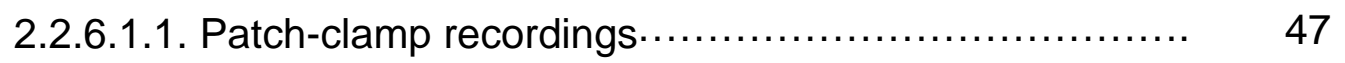

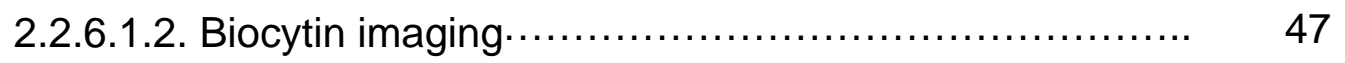

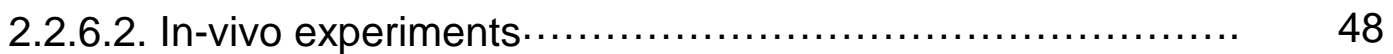

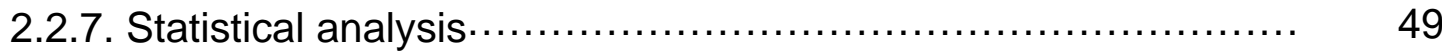

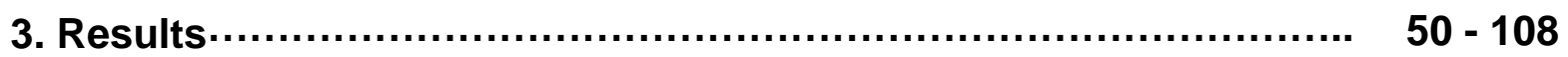

3.1. Production and characterisation of poly- and monoclonal antibodies.. $\quad 50$

3.1.1. Production and characterisation of polyclonal anti-serotonin 4(a), 7, and 2B receptor antibodies................ 50

3.1.1.1. Sequence alignment and peptide-selection and -coupling.. $\quad 50$

3.1.1.2. Antibody titre of the antisera from rabbits.................. 54

3.1.1.3. Purification of the polyclonal antibodies from serum of rabbits ........................................... 55

3.1.1.4. Characterisation of the polyclonal antibodies recognising the serotonin 4(a), 7, and 2B receptor isoforms ............. 55

3.1.1.4.1. Anti-serotonin 4(a) receptor antibody ................. 55

3.1.1.4.2. Anti-serotonin 7 receptor antibody .................... 57

3.1.1.4.3. Anti-serotonin 2B receptor antibody $\ldots \ldots \ldots \ldots \ldots \ldots \ldots \ldots \ldots \ldots$

3.1.2. Production and characterisation of monoclonal anti-

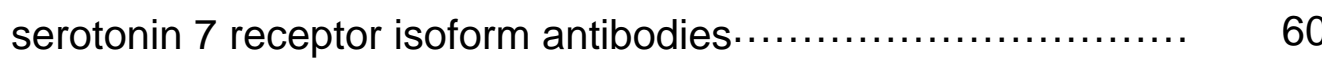

3.1.2.1. Determination of the antibody titre of immunised BALB/c-mice and Syrian hamsters

3.1.2.2. Isotype-characterisation of the Syrian hamster monoclonal antibodies 5HT7R/18 and 5HT7R/220 ..........

3.1.2.3. Purification of the monoclonal $5 \mathrm{HTTR} / 18$ and 5HT7R/220 antibodies from Syrian hamster hetero-hybridoma supernatants.

3.1.2.4. Characterisation of the monoclonal antibodies (clone 5HT7R/220)

3.1.3. Test of the antibodies for cross-reactivities using an ELISA with solid phase-coated antigen 
3.2. Expression and function of the serotonin 4(a) receptor

isoform in the respiratory system....

3.2.1. Expression of $5-\mathrm{HT}_{4(\mathrm{a})}$ receptors in neurones of the preBötzinger complex

3.2.2. Expression of $5-\mathrm{HT}_{4(\mathrm{a})}$ receptors in identified respiratory neurones

3.2.3. Compensation of the fentanyl-induced depression of the respiratory activity by selective activation of the $5-\mathrm{HT}_{4(\mathrm{a})}$ receptor using BIMU-8.

3.2.4. Expression of $5-\mathrm{HT}_{4(\mathrm{a})}$ receptors in neurones of the spinal cord.

3.3. Expression of the $5-\mathrm{HT}_{4(\mathrm{a})}$ and $\mu$-opioid receptors in the preBötzinger complex during the development

3.3.1. Analysis of the mRNA expression specific for the $5-\mathrm{HT}_{4(\mathrm{a})}, \mu$-opioid, and NK-1 receptors, and the nestin protein in the PBC or its precursor structure

3.3.2. $5-\mathrm{HT}_{4(\mathrm{a})}$ receptor expression in the $\mathrm{PBC}$ of the rat during the development...

3.3.3. Co-expression of the $5-\mathrm{HT}_{4(\mathrm{a})}$ and $\mathrm{NK}-1$ receptors in neurones within the PBC during the development.

3.3.4. Co-expression of the $5-\mathrm{HT}_{4(\mathrm{a})}$ and $\mu$-opioid receptors in the PBC during the development....

3.3.5. Analysis of the $5-\mathrm{HT}_{4(\mathrm{a})}$ and $\mu$-opioid receptor expression in neurones of the spinal cord.

3.3.6. 5- $\mathrm{HT}_{4(\mathrm{a})}$ receptor expression in identified embryonic respiratory neurones.

3.3.7. Analysis of the degree of differentiation of the embryonic and neonatal PBC....

3.3.7.1. Analysis of the nestin protein expression pattern during embryonic and neonatal development stages.

3.3.7.2. Analysis of the co-expression of the $5-\mathrm{HT}_{4(\mathrm{a})}$ receptor and the nestin protein in cells within the embryonic and neonatal PBC....

3.3.7.3. Characterisation of the nestin-immunoreactive cells using the glial fibrillary acidic protein (GFAP).

3.3.8. Analysis of the of the $5-\mathrm{HT}_{4(\mathrm{a})}$ receptor expression in identified glial cells 
3.4. Expression and function of the serotonin $1 \mathrm{~A}$ and 7 receptor isoforms in the respiratory system

3.4.1. Expression of the $5-\mathrm{HT}_{1 \mathrm{~A}}, 5-\mathrm{HT}_{7}$, and $\mu$-opioid receptors in neurones within the PBC and the spinal cord....

3.4.2. Expression of the $5-\mathrm{HT}_{1 \mathrm{~A}}$ and $5-\mathrm{HT}_{7}$ receptor-specific mRNA in identified respiratory neurones

3.4.3. Activation of the respiratory activity by systemic application of 8-OH-DPAT

3.4.4. Compensation of the fentanyl-induced depression of the respiratory activity by $8-\mathrm{OH}-\mathrm{DPAT}$.

3.5. Expression and function of the serotonin $2 \mathrm{~A}$ and $2 \mathrm{~B}$ receptor isoforms in the respiratory system

3.5.1. Expression of the $5-\mathrm{HT}_{2 \mathrm{~A}}$ and $5-\mathrm{HT}_{2 \mathrm{~B}}$ receptors in neurones within the $\mathrm{PBC}$.

3.5.2. In-vivo analysis of systemic effects of the $5-\mathrm{HT}_{2 \mathrm{~A}}$ and $5-\mathrm{HT}_{2 \mathrm{~B}}$ receptors on the breathing pattern

3.6. Analysis of the distribution patterns of the serotonin $1 \mathrm{~A}, 2 \mathrm{~A}, 2 \mathrm{~B}, 4(\mathrm{a})$, and 7 receptor isoforms in the ponto-medullary respiratory system.....

4. Discussion

4.1. The opioid-induced depression of the respiratory activity compensated by selective activation of the serotonin 4(a) receptor isoform without loss of the analgetic effects of the opioid.....

4.2. Development of the serotonin 4(a) and $\mu$-opioid receptor expression in the preBötzinger complex (PBC)

4.3. The opioid-induced depression of the respiratory activity compensated by 8-OH-DPAT without loss of the analgetic effects of the opioid

4.4. Expression and function of the serotonin $2 A$ and $2 B$ receptor isoforms in the respiratory system.

5. Literature

\section{Curriculum Vitae}

\section{Acknowledgements}




\section{Summary}

A variety of different serotonin receptors (5-HTR) are known to modify neuronal network activity by their specific modulatory action on synaptic transmission and postsynaptic excitability through G-protein activated second messenger pathways. To obtain more information about the distribution of the $5-\mathrm{HT}_{1 \mathrm{~A}}, 5-\mathrm{HT}_{2 \mathrm{~A}}, 5-\mathrm{HT}_{2 \mathrm{~B}}, 5-\mathrm{HT}_{4(\mathrm{a})}$, and $5-\mathrm{HT}_{7}$ receptors within the respiratory network, specific poly- and monoclonal antibodies against the $5-\mathrm{HT}_{2 \mathrm{~B}}, 5-\mathrm{HT}_{4(\mathrm{a})}$, and $5-\mathrm{HT}_{7}$ receptors were produced. These specific antibodies together with commercially available antibodies revealed that all receptors were expressed in the preBötzinger complex that represents an important part of the respiratory network essential for respiratory rhythm generation.

The $5-\mathrm{HT}_{4(\mathrm{a})} \mathrm{R}$ was strongly co-expressed with the $\mu$-opioid receptor $(\mu-\mathrm{OR})$ in respiratory neurones of the PBC shown by immunohistochemistry and single-cell RTPCR analysis. These data provided evidence for a convergent signal transduction pathway of both receptors which stimulate $\left(5-\mathrm{HT}_{4(\mathrm{a})} \mathrm{R}\right)$ or inhibit $(\mu-\mathrm{OR})$ the activity of the adenylyl cyclase. The physiological relevance was tested in a fully intact animal model. Systemic application of the $5-\mathrm{HT}_{4(\mathrm{a})} \mathrm{R}$-agonist BIMU-8 produced a significantly increased respiratory activity and even recovered opioid-induced respiratory depression, while the opioid-induced analgesia remained unaffected. The continuity of analgesia based on the remarkable fact that neurones of the dorsal horn, responsible for spinal inhibition of nociception on spinal cord level, did not express the $5-\mathrm{HT}_{4(\mathrm{a}) \mathrm{R}} \mathrm{R}$, while the $\mu-O R$ was abundantly expressed. These findings demonstrate clinical relevance of selective $5-\mathrm{HT}_{4(\mathrm{a})} \mathrm{R}$ activation in the treatment or protection against respiratory failure without loss of the anti-nociceptive effect of opioids.

Recent studies indicated that the $5-\mathrm{HT}_{4(\mathrm{a})} \mathrm{R}$ also exert a neurotrophic function and might play a role in the structural development of the respiratory network itself. In the development study, the 5- $\mathrm{HT}_{4(\mathrm{a})} \mathrm{R}$ and $\mu$-OR expression in $\mathrm{PBC}$-neurones during embryonic and postnatal periods (E 16 - P 10) was examined. Immunohistochemistry revealed that $5-\mathrm{HT}_{4(\mathrm{a})} \mathrm{R}$-immunoreactivity was predominantly found in the neuropil, while somatic staining was sporadic at late embryonic (E 16 - E 18) stages. At birth, a dramatic turn to a predominant somatic staining was observed, while neuropil staining was greatly reduced to disappear at an age of $P$ 4. At all development stages, 5-

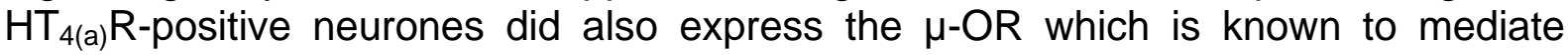
neurotrophic functions. The results of the development study provide evidence that the $5-\mathrm{HT}_{4(\mathrm{a})} \mathrm{R}$ is not only important for neuromodulation of cellular excitability, but also activates neurotrophic factors that exert a significant function in network formation during embryonic stages. The relocation of $5-\mathrm{HT}_{4(\mathrm{a})} \mathrm{R}$-immunoreactivity from the neuropil to the soma of neurones indicates that the network formation within the PBC might be completed at birth.

The 5- $\mathrm{HT}_{1 \mathrm{~A}} \mathrm{R}$ was strongly co-expressed with the $5-\mathrm{HT}_{7}$ and $\mu$-opioid receptors in the PBC. The effects on breathing pattern of the $5-\mathrm{HT}_{1 \mathrm{~A}}$ and $5-\mathrm{HT}_{7}$ receptor agonist 8-OH-DPAT was analysed in-vivo. Both receptor isoforms as well converge on the signalling cascade of $\mu-\mathrm{OR}$, and systemic application of 8-OH-DPAT increased respiratory activity. The pharmacologically evoked excitatory effect was due to $5-\mathrm{HT}_{1 \mathrm{~A}} \mathrm{R}$ activation, because WAY 100635 , a specific antagonist for the $5-\mathrm{HT}_{1 \mathrm{~A}} \mathrm{R}$, blocked this effect, while SB 269970, a specific antagonist for the $5-\mathrm{HT}_{7} \mathrm{R}$, had no effects. Interestingly, opioid-induced depression of respiratory activity was successfully recovered by subsequent application of 8-OH-DPAT without affecting analgesia. 
A secondary effect of 8-OH-DPAT on $\mathrm{G}_{\mathrm{s}}$-coupled $5-\mathrm{HT}_{7}$ receptors can be largely excluded. However, 5- $\mathrm{HT}_{1 \mathrm{~A}}$ receptors utilise the identical signalling cascade inhibiting the adenylyl cyclase like $\mu$-OR and thus, the rescue phenomenon is hardly to explain with a simple molecular mechanism. Therefore, a more detailed network analysis is required to understand if specific subpopulations of respiratory neurones are affected by 8-OH DPAT potentially leading to a disinhibition or reconfiguration of neuronal circuits controlling breathing. Nevertheless, the physiological significance of complex network interaction during the $5-\mathrm{HT}_{1 \mathrm{~A}} \mathrm{R}$-mediated recovery from opioid-induced respiratory arrest is yet not fully understood.

The 5- $\mathrm{HT}_{2 \mathrm{~A}}$ and $5-\mathrm{HT}_{2 \mathrm{~B}}$ receptor isoforms were strongly co-expressed in neurones of the PBC shown by immunohistochemistry and RT-PCR analysis. Both receptor isoforms utilise a $G_{q}$-mediated signalling cascade leading to activation of phospholipase $\mathrm{C}$ and $\mathrm{IP}_{3} / \mathrm{DAG}$ pathways. This signal transduction pathway predicts an excitatory action of agonists for both receptors on respiration as has previously been verified on cellular level in earlier studies.

Systemic application of the $5-\mathrm{HT}_{2 \mathrm{~A}} \mathrm{R}$-agonist $\alpha$-methyl-5-HT caused only a transient respiratory depression. This depression was accompanied by a pronounced increase in mean arterial pressure (MAP). The respiratory activity recovered, while MAP remained depressed and a hypotonia persisted. Injection of the $5-\mathrm{HT}_{2 \mathrm{~A}} \mathrm{R}$-antagonist Ketanserin caused only an insignificant transient respiratory depression and a mild decrease in MAP. Injection of both the $5-\mathrm{HT}_{2 \mathrm{~B}} \mathrm{R}$-agonist $\mathrm{BW} 723 \mathrm{C} 86$ and the antagonist LY 272015 caused neither transient nor longer lasting changes of breathing and MAP. All attempts to recover opioid-induced respiratory depression failed.

These findings suggest that systemic activation of $5-\mathrm{HT}_{2 \mathrm{~A}}$ or $5-\mathrm{HT}_{2 \mathrm{~B}}$ receptors does not exert an excitatory effect on breathing.

Taken together, although all serotonin receptors analysed are expressed in the respiratory system, only systemic activation of the serotonin $1 \mathrm{~A}$ and 4 receptor isoforms restored potentially opioid-induced respiratory depression without loss of analgesia. This might open novel strategies for an effective treatment of critical clinical situations caused by opioid treatment. 


\section{Abbreviations}

\section{Terms:}

\begin{tabular}{|c|c|}
\hline $\mathrm{Ab}$ & antibody \\
\hline$A B C$ & avidin-biotin-enzyme complex \\
\hline $\mathrm{AC}$ & adenylyl cyclase \\
\hline $\mathrm{Ag}$ & antigen \\
\hline AP & alkaline phosphatase \\
\hline BötC & Bötzinger complex \\
\hline BSA & bovine serum albumin \\
\hline CAMP & cyclic adenosine $5^{\prime}, 3^{\prime}$-monophosphate \\
\hline cFA & complete Freund's adjuvant \\
\hline CFR & C-fibre reflex \\
\hline ChAT & choline acetyl transferase \\
\hline $\mathrm{ddH}_{2} \mathrm{O}$ & double distilled water \\
\hline DAG & diacylglycerol \\
\hline DIG & digoxigenin \\
\hline DNA & deoxyribonucleic acid \\
\hline DRG & dorsal respiratory group \\
\hline dsDNA & double-stranded DNA \\
\hline DSHB & developmental studies hybridoma bank \\
\hline ECL & enhanced chemiluminescence \\
\hline ELISA & enzyme-linked immunosorbent assay \\
\hline Fab & antigen-binding fragment \\
\hline FACS & fluorescence-activated cell sorter \\
\hline FCS & fetal calf serum \\
\hline Fc & crystalisable (constant) fragment \\
\hline fig. & figure \\
\hline FMM & fluorescence mounting medium \\
\hline GFAP & glial fibrillary acidic protein \\
\hline 5-HT & 5-hydroxytryptamine (serotonin) \\
\hline 5-HTR & serotonin receptor \\
\hline HT & hypoxanthine, thymidine (growth medium) \\
\hline HAT & hypoxanthine, aminopterin and thymidine (growth medium) \\
\hline HGPRT & hypoxanthine guanosine phosphoribosyl transferase \\
\hline HRP & horseradish peroxidase \\
\hline iFA & incomplete Freund's adjuvant \\
\hline $\lg$ & immunoglobulin \\
\hline IL & Interleukin \\
\hline 10 & inferior olive \\
\hline $1 \mathrm{O}_{\mathrm{Pr}}$ & inferior olive, principal nucleus \\
\hline i. p. & intraperitoneal \\
\hline i. v. & intravenous \\
\hline KF & Kölliker-Fuse nucleus \\
\hline $\mathrm{KLH}$ & Keyhole-limpet hemocyanin \\
\hline LMW & low molecular weight marker \\
\hline LRt & lateral reticular nucleus \\
\hline MAP & mean arterial pressure \\
\hline MBP & myelin basic protein \\
\hline $\mathrm{mAb}$ & monoclonal antibody \\
\hline
\end{tabular}




$\begin{array}{ll}\text { MWM } & \text { molecular weight marker } \\ n & \text { number of experiments } \\ \text { NA } & \text { ambigual nucleus } \\ \text { NCBI } & \text { national center for biotechnology information } \\ \text { NTS } & \text { nucleus solitary tract } \\ \text { OD } & \text { optical density (absorbance) } \\ \text { p. a. } & \text { pro analysi } \\ \text { pAb } & \text { polyclonal antibody } \\ \text { PAGE } & \text { polyacrylamide gel electrophoresis } \\ \text { PAP } & \text { peroxidase anti-peroxidase } \\ \text { PBC } & \text { preBötzinger complex } \\ \text { PBS } & \text { phosphate buffered saline } \\ \text { PGi } & \text { paragigantocellular nucleus } \\ \text { PKA } & \text { protein kinase A } \\ \text { PKC } & \text { protein kinase C } \\ \text { PLC } & \text { phospholipase C } \\ \text { PVDF } & \text { polyvinylidine dichloride } \\ \text { pyx } & \text { pyramidal tract } \\ \text { RNA } & \text { ribonucleic acid } \\ \text { r-RNA } & \text { ribosomal RNA } \\ \text { t-RNA } & \text { transfer RNA } \\ \text { RTN } & \text { retrofacial nucleus } \\ \text { RVM } & \text { respiratory minute volume } \\ \text { S. C. } & \text { subcutaneous } \\ \text { SSC } & \text { standard saline citrate buffer } \\ \text { SSDNA } & \text { single-stranded DNA } \\ \text { TBS } & \text { Tris buffered saline } \\ \text { TFR } & \text { tail-flick response } \\ \text { VRG } & \text { ventral respiratory group } \\ \text { WNZ } & \text { white new Zealand } \\ \text { X } & \text { vagal nucleus } \\ \text { XII } & \text { hypoglossal nucleus } \\ & \end{array}$

\section{Chemicals:}

$\begin{array}{ll}\text { ABTS } & 2,2^{\prime} \text {-azino-bis [3-ethylbenzthiazoline-6-sulfonic acid] } \\ \text { AMS } & \text { ammonium sulfate } \\ \text { APS } & \text { ammonium persulfate } \\ \text { Bis } & \mathrm{N}, \mathrm{N}^{\prime} \text {-methylene bisacrylamide } \\ \text { Bromophenol blue } & 3^{\prime}, 3^{\prime \prime}, 5^{\prime}, 5^{\prime \prime} \text {-tetrabromophenolsulfonephthalein } \\ \text { DAB } & 3,3^{\prime} \text {-diaminobenzidine }\left[3,3^{\prime}, 4,4^{\prime} \text { tetraaminobiphenyl] }\right. \\ \text { DEPC } & \text { diethylpyrocarbonate } \\ \text { DMF } & \mathrm{N}, \mathrm{N} \text {-dimethylformamide } \\ \text { DMSO } & \text { dimethyl sulfoxide } \\ \text { DTE } & \text { dithioerythritol } \\ \text { DTT } & \text { dithiothreitol } \\ \text { EDTA } & \text { ethylenediamine-tetra acetic acid } \\ \mathrm{H}_{2} \mathrm{O}_{2} & \text { hydrogen peroxide } \\ \mathrm{HCl} & \text { hydrochlorid acid } \\ 2 \mathrm{ME} & \text { 2-mercaptoethanol } \\ \text { PEG } & \text { polyethylene glycol }\end{array}$




\begin{tabular}{|c|c|}
\hline PMSF & phenylmethanesulfonyl fluoride \\
\hline Ponceau S & $\begin{array}{l}\text { 3-hydroxy-4-[2-sulfo-4-(sulfo-4-(sulpho-phenylazo)phenylazo]-2, } \\
\text { 7-naphthalene disulfonic acid }\end{array}$ \\
\hline SDS & sodium dodecyl sulphate \\
\hline SMCC & $\begin{array}{l}\text { 4-[N-maleimidomethyl]-cyclohexane-1-carboxylic acid N- } \\
\text { succinimidyl ester }\end{array}$ \\
\hline $\begin{array}{l}\text { SQ 22,536 } \\
\text { TCA }\end{array}$ & $\begin{array}{l}\text { 9-(tetrahydro-2-furanyl)-9H-purin-6-amine } \\
\text { trichloro acetic acid }\end{array}$ \\
\hline TEMED & $\mathrm{N}, \mathrm{N}, \mathrm{N}^{`}, \mathrm{~N}^{`}$-tetramethylene-ethylenediamine \\
\hline TRIS & Tris (hydroxymethyl) aminoethane \\
\hline Triton $^{\circledR} \mathrm{X}-100$ & t-octyl-phenoxy-polyethoxy-ethanol \\
\hline TWEEN $^{\circledR} 20$ & poly-oxy-ethylene-sorbitan monolaurate \\
\hline
\end{tabular}

\section{Serotonergics:}

\begin{tabular}{|c|c|}
\hline $\begin{array}{l}\text { 8-OH-DPAT } \\
\text { WAY } 100635\end{array}$ & $\begin{array}{l}\text { 8-hydroxy-2-dipropylaminotetralin hydrobromide } \\
\mathrm{N} \text {-[2-[4-(2-methoxyphenyl)-1-piperazinyl]ethyl]- } \mathrm{N} \text {-2-pyridinyl- } \\
\text { cyclohexanecarboxamide maleate salt }\end{array}$ \\
\hline$\alpha$-methyl-5-HT & $\alpha$-methyl-5-hydroxytryptamine \\
\hline Ketanserin & $\begin{array}{l}3-[2-[4-(4-\text { fluorobenzoyl)-1-piperidinyl] }] \text { ethyl]-2,4 [1H, 3H]- } \\
\text { quinazolinedione }\end{array}$ \\
\hline BW 723C86 & 1-[5-(2-thienylmethoxy)-1H-3-indolyl]propan-2-amine \\
\hline LY 272015 & $\begin{array}{l}\text { 6-methyl-1,2,3,4-tetrahydro-1-[3,4-dimethoxyphenyl)methyl]-9H- } \\
\text { pyrido[3,4-b]indole }\end{array}$ \\
\hline BIMU-8 & $\begin{array}{l}\text { endo-N-(8-methyl-8-azabicyclo[3.2.1]oct-3-yl)-3-isopropyl-2- } \\
\text { oxo-2,3-dihydrobenzimidazole-1-carboxamide }\end{array}$ \\
\hline $\begin{array}{l}\text { GR } 113808 \\
\text { SB } 269970\end{array}$ & $\begin{array}{l}\text { [1-[2-[(methylsulfonyl)amino]ethyl]-4-piperidinyl]methyl ester } \\
\text { (2R)-1-[(3-hydroxyphenyl) sulphonyl]-2-[2-(4-methyl-1- } \\
\text { piperidinyl) ethyl pyrrolidine }\end{array}$ \\
\hline
\end{tabular}

\section{Units:}

$\begin{array}{ll}\mathrm{A} & \text { ampere } \\ { }^{\circ} \mathrm{C} & \text { degree centigrade (Celsius) } \\ \mathrm{g} & \text { gram } \\ \mathrm{xg} & \text { multiplied by acceleration of gravity } \\ \mathrm{h} & \text { hour } \\ \mathrm{k} & \text { kilo }\left(10^{3}\right) \\ \mathrm{kb} & \text { kilobase } \\ \mathrm{kDa} & \text { kilodalton } \\ \mathrm{kg} & \text { kilogram } \\ \lambda & \text { lambda (wavelenght) } \\ \mathrm{I} & \text { litre } \\ \mathrm{M} & \text { moles per litre } \\ \mathrm{m} & \text { milli }\left(10^{-3}\right) \\ \mathrm{mM} & \text { millimoles per litre } \\ \mathrm{mA} & \text { milliampere } \\ \mu & \text { micro }\left(10^{-6}\right) \\ \mu \mathrm{g} & \text { microgram } \\ \mathrm{min} & \text { minute }\end{array}$




$\begin{array}{ll}\mathrm{ml} & \text { millilitre } \\ \mu \mathrm{l} & \text { microlitre } \\ \mathrm{Mr} & \text { relative molecular mass; molecular weight } \\ \mathrm{n} & \text { nano }\left(10^{-9}\right) \\ \mathrm{N} & \text { normal } \\ \mathrm{nm} & \text { nanometre } \\ \mathrm{p} & \text { pico }\left(10^{-12}\right) \\ \mathrm{RT} & \text { room temperature } \\ \mathrm{s} & \text { second } \\ \mathrm{rpm} & \text { rounds per minute } \\ \mathrm{V} & \text { volt } \\ \mathrm{v} & \text { volume } \\ \mathrm{v} / \mathrm{v} & \text { volume per volume } \\ \mathrm{W} & \text { weight } \\ \mathrm{w} / \mathrm{v} & \text { weight per volume } \\ \mathrm{w} / \mathrm{w} & \text { weight per weight }\end{array}$

5. Amino acid abbreviations (single-letter code):
A alanine
Q glutamine
L leucine
$\mathbf{R}$ arginine
E glutamic acid
K lysine
S serine
N asparagine
M methionine
D aspartic acid
G glycine
F phenylalanine
C cysteine
$\mathbf{H}$ histidine
$\mathbf{P}$ proline
$\mathbf{T}$ threonine
W tryptophan
$\mathbf{Y}$ tyrosine
V valine 


\section{Introduction}

\subsection{Respiratory disturbances}

Breathing is a fundamental physiological process to provide oxygen for the body and is controlled by the nervous system. Respiratory disturbances mainly originating from failure of neuronal interactions within the respiratory network. According to clinical experiences, the two most frequently occurring disorders are central apnoea and apneusis. These disorders are often life-threatening because they arrest lung ventilation and produce successive hypoxia (lack of oxygen) [Saito et al. (2002), Wilken et al. (1997)]. Apneusis (an abnormal respiratory pattern consisting of a pause at inspiration and prolonged breath holding) and central apnoea (cessation of breathing owning to lack of inspiratory movements) may occur in association with e.g. brainstem tumours and degenerative brain disorders such as olivo-ponto-cerebellar hypoplasia [Wilken et al. (1997)], but they can also occur in consequence of opioid or barbiturate application [Lalley et al. (1994b), Sahibzada et al. (2000)]. Opioids produce desired analgesia in numerous qualities of pain, but their use is limited by the risk of apnoea. This impairs their applicability in a lot of clinical situations. Recent studies have been shown that application of the serotonin $1 \mathrm{~A}$ receptor isoformagonist 8-OH-DPAT can counteract both apneustic breathing disturbances [Haji et al. (2000), Lalley et al. (1994b)] and opioid-induced apnoea [Sahibzada et al. (2000)].

\subsection{Localisation and function of the preBötzinger complex (PBC)}

The respiratory rhythm of mammals originates from the preBötzinger complex (PBC) and neighbouring structures in the lower brainstem [Onimaru and Homma (2003), Smith et al. (1991)]. The PBC contains all classes of respiratory neurones located within the ventrolateral medulla that are essential for mammalian respiratory rhythm generation [Connelly et al. (1992), Feldman et al. (2003), Rekling and Feldman (1998), Schwarzacher et al. (1995), Smith et al. (1991)]. The nucleus ambiguus (NA) and the appearance of the principal nucleus of the inferior olive $\left(\mathrm{IO}_{\mathrm{Pr}}\right)$ [Alheid et al. (2002), Schwarzacher et al. (1995)] are necessary for the anatomical identification of the PBC which is known in adult rats to lie ventro-lateral to the nucleus ambiguus, caudal to the retrofacial nucleus, and rostral to the anterior tip of the lateral reticular nucleus (Bregma-level $-12.0 \mathrm{~mm}$ to $-12.5 \mathrm{~mm}$ ) (fig. 1) [Gray et al. (1999), Guyenet and Wang (2001), Paxinos and Watson (1986), Wang et al. (2001)]. Electrophysiological recordings, pharmacological manipulations, and lesions, both in-vitro and invivo, confirmed that the PBC is critically involved in the generation of the respiratory rhythm [Gray et al. (2001), Pierrefiche et al. (1998), Smith et al. (1991), Solomon et al. (1999)]. According to Gray et al. (1999), PBC-neurones were identified by substance P-reactive neurokinin-1 receptor (NK-1R)-immunoreactivity, although NK-1Rpositive neurones are also present outside the PBC. However, the NK-1R-expressing cells of the ventral respiratory group (VRG) are a heterogeneous group of predominantly glutamatergic neurones that include subpopulations of respiratory pre-motor neurones [Wang et al. (2001), Guyenet et al. (2002)]. Bilateral destructions of NK-1Rexpressing neurones within the PBC using saporin-conjugated substance $P$ results in an ataxic breathing [Gray et al. (2001)]. Therefore, the substance P-reactive neurokinin-1 receptor has been proposed to be a marker for the anatomical identification of the PBC. Recent studies demonstrated that this marker is also useful to identify the embryonic PBC [Pagliardini et al. (2003)]. 


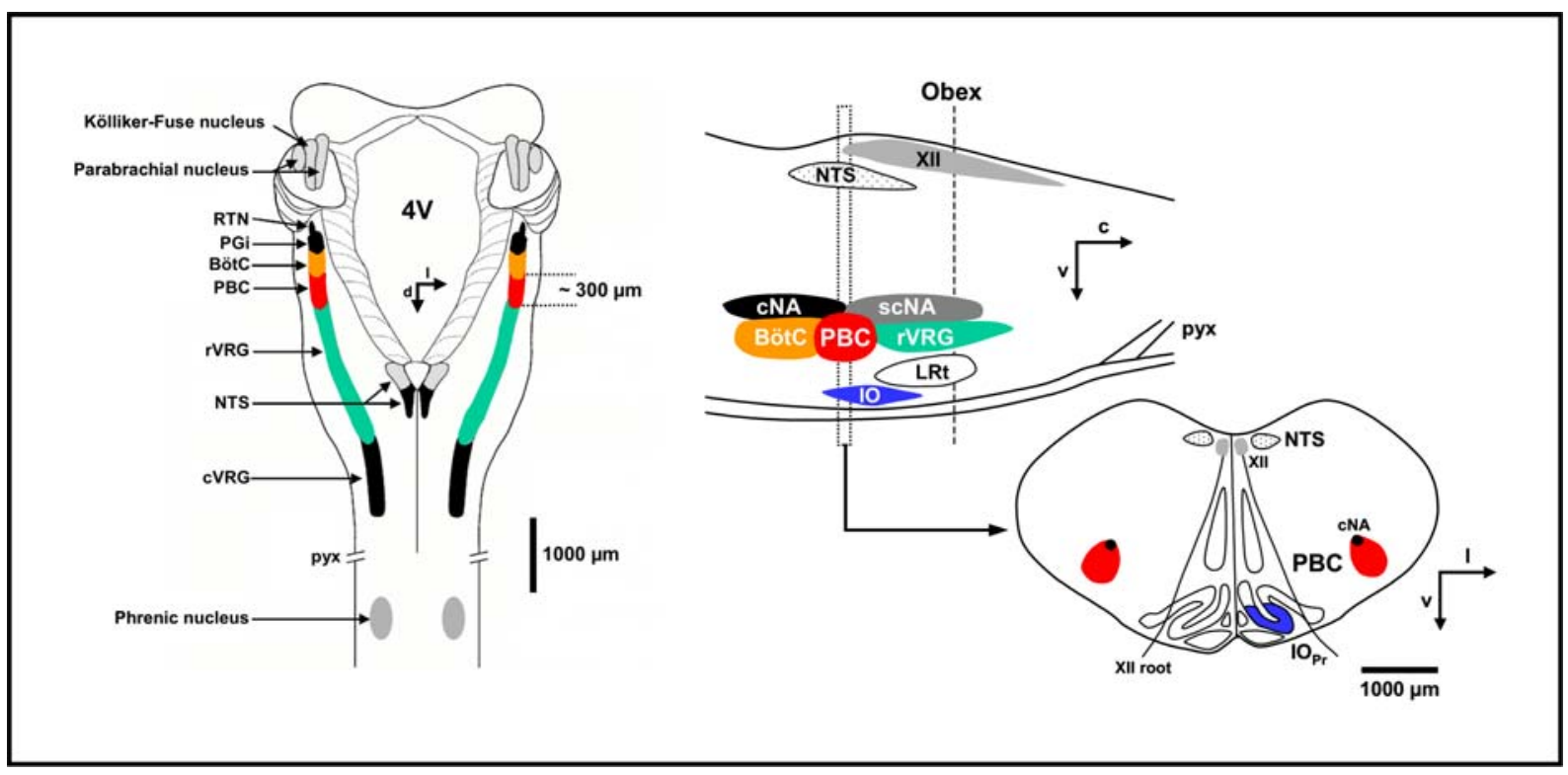

Figure 1. Schematic representation of the localisation of the preBötzinger complex within the rat brainstem: on the left side a dorsal topview of the rat brainstem after removal of the cerebellum is shown. On the right side a sagittal section (top) and a transversal slice (bottom panel) which contains the PBC are shown. Abbreviations: Bötzinger complex (BötC), preBötzinger complex (PBC), nucleus ambiguus, compact part (cNA) or semicompact part (scNA), lateral reticular nucleus (LRt), ventral respiratory group (VRG), hypoglossal nucleus (XII), principal nucleus of the inferior olive $\left(I O_{P r}\right)$, nucleus solitary tract (NTS), pyramidal decussation (pyx), caudal (c), ventral (v), lateral (I), rostral (r).

\subsection{Respiratory rhythm generation}

Six different classes of neurones have been defined according to their firing patterns, their membrane potential changes, and their synaptic inputs [Bianchi et al. (1995), Richter (1996), Richter and Spyer (2001)]. Four classes of neurones fire during inspiration: the pre-inspiratory neurones (pre-I) which fire at the transition between expiration and inspiration, the early-inspiratory neurones (early-l) which fire from the beginning to the middle of inspiration, the ramp-inspiratory neurones (ramp-I) which fire throughout inspiration, and the late-inspiratory neurones (late-I) which are active at the end of inspiration. During phase transition between inspiration and expiration (post-inspiration), post-inspiratory neurones (post-I) are activated. The expiratory neurones $\left(E_{2}\right)$ discharge during expiration. The activity of these neurones can be recorded at various brainstem loci. The respiratory outflow in spinal motoneurones, supplying respiratory muscles, originates from the bilaterally organised dorsal (DRG) and ventral group of respiratory neurones (VRG) within the lower brainstem [Bianchi et al. (1995)] in which only the VRG is essential for rhythm generation [Richter and Spyer (2001)]. To explain respiratory rhythmogenesis, these six different classes of respiratory neurones are proposed to form a network of mostly antagonistically connected neurones generating the rhythm (fig. 2), while other groups of neurones shape the activity pattern [Richter (1996)]. In this network model synaptic interaction and cooperative adjustment of excitability levels through voltage-regulated ion conductances play a critical role for rhythm generation [Richter et al. (1992)]. Excitatory synaptic interaction operates through glutamatergic synaptic activation through AMPA- and NMDA-receptors, while periodic inhibition of synaptic inputs is mediated by GABA and glycine receptors [Richter et al. (1996)]. 


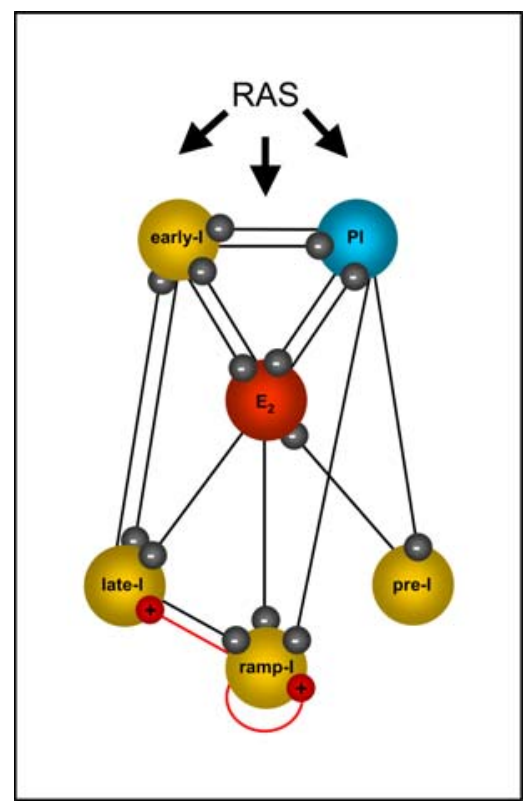

Figure 2. Schematic representation of the model for the brainstem respiratory network: this network model mainly functions on the basis of inhibitory synapses between 6 different types of respiratory neurones [pre-inspiratory (pre-I), early-inspiratory (early-I), ramp-inspiratory (ramp-I), lateinspiratory (late-I), post-inspiratory (post-I), and expiratory $\left(E_{2}\right)$ neurones] which generate the 3 phases of breathing pattern [inspiration (I), post-inspiration $(p-I)$, and expiration $(E)]$. In this network model reciprocal inhibitions mediated by glycine and GABA receptors play the key role to generate the rhythm, and few excitatory synapses are involved in the feedback loops maintaining the inspiratory or expiratory phases. The respiratory network is driven by the reticular activating system (RAS), the socalled 'arousal' system.

However, there is also evidence that in neonatal mammals as well as under certain pathological situations in adult mammals the respiratory rhythm may derive from socalled 'pacemaker'-neurones [Büsselberg et al. (2003), Feldman et al. (2003), Richter and Spyer (2001)]. The pacemaker theory postulates that the respiratory rhythm originates primarily from these respiratory 'burster'-neurones which transmit synaptically rhythmic bursts to inspiratory-follower neurones driving an inspiratory rhythm [Feldman et al. (1991), Koshiya and Smith (1999)]. A combination of the network and pacemaker theory is the so-called 'hybrid-pacemaker-network model', however, postulates that the various respiratory activity patterns can be simulated when synaptic activity sets the voltage of pacemaker-neurones [Butera et al. (1999), Smith et al. (2000)]. 


\subsection{The serotonergic system}

The fundamental importance of the central serotonergic system is reflected in the extensive innervation of brain areas by serotonin (5-hydroxytryptamine, 5-HT) nerve projections (fig. 3). The bioamine serotonin, synthesised from the amino acid tryptophan, was initially isolated from the blood as a serum factor that increased smooth muscle tone [Page (1952)] and was firstly described in the mammalian brain in the 1950s [Twarog and Page (1953)]. Cell bodies containing 5-HT are located in nine discrete cell clusters (nuclei raphé) which are located near the midline of the brainstem [Dahlström and Fuxe (1964)]. The most caudal raphé nuclei (B1 - B4) project mainly to the brainstem and the gray matter of the spinal cord, while the 5-HTneurones innervating the forebrain mainly originate from the dorsal raphé nucleus and median raphé nucleus (fig. 3). According to Jacobs and Azmitia (1992), the serotonergic system appears to be similar in primates and non-primates in the distribution of 5-HT cell bodies and their projection network.

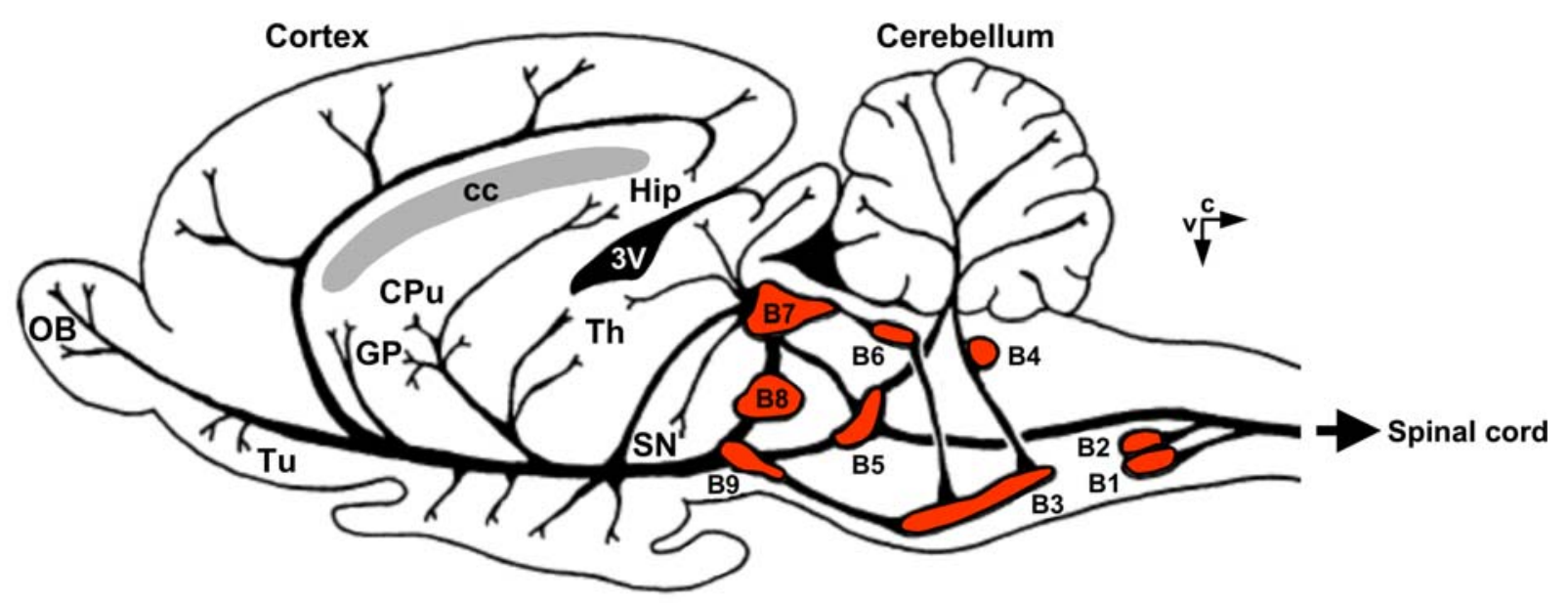

Figure 3. Schematic representation of the localisation of the serotonergic nuclei (B1 - B9) within the rat brain and their major projections: abbreviations: nucleus raphé pallidus (B1), nucleus raphé obscurus (B2), nucleus raphé paragigantocellularis (B3), nucleus raphé magnus (B4), nucleus raphe pontis resp. medianus (B5), nucleus raphé dorsalis (B6 and B7), nucleus centralis superior (B8), nucleus reticularis pontis (B9), third ventricle (3V), corpus callosum (cc), hippocampus (Hip), olfactory bulb (OB), olfactory tubercle (Tu), globus pallidus (GP), caudate putamen (CPu), substantia nigra $(\mathrm{SN})$, thalamus (Th), caudal (c), ventral (v).

The raphé system is tonically active and this activity is modulated by different factors to increase or inhibit the release of serotonin [Richter et al. (1999)]. Due to the wide axonal projections of the serotonergic system, it is not surprising that the 5-HT metabolism has been associated with the aetiology of various diseases including anxiety, depression, migraine, obsessive compulsive disorders, panic disorders, schizophrenia, and also with respiratory disturbances [Hilaire et al. (1993), Narita et al. (2001), Naughton et al. (2000), Olson (1987), Saito et al. (1999), Wilken et al. (1997)]. Therefore, the serotonergic system is an important target for the treatment not only of psychiatric disorders, but also of respiratory disturbances [Richter et al. (2003)]. 


\subsection{Serotonin receptor isoforms}

The serotonergic system belongs to the 'arousal system which drives the respiratory network and therefore produce modifications of corresponding intracellular signalling within respiratory regions resulting in changes of network excitability. The adjustment of network excitability is also modified by catecholamines, adenosine, acetylcholine, opioids, and other neuropeptides [Bonham (1995), Richter et al. (1999)].

The exceptional relevance of the neuromodulator serotonin is not only reflected by the wide axonal 5-HT-projections, but also by the existing large family of serotonin receptors (5-HTR) [Barnes and Sharp (1999)]. At presence, seven 5-HT receptor subfamilies $\left(5-\mathrm{HT}_{1}-5-\mathrm{HT}_{7}\right)$ with 14 different receptor isoforms are identified. Detailed research on each of the different subtypes is required to understand the complexity of the serotonergic system and the functional role of the different receptor subtypes in the respiratory system. Except for the $5-\mathrm{HT}_{3} \mathrm{R}$, which is a transmittergated $\mathrm{Na}^{+} / \mathrm{K}^{+}$-ion-channel and not functionally expressed in the respiratory system [Richter et al. (2003)], all other 5-HTR belong to the family of G-protein-coupled seven-transmembrane-domain receptors (GPCRs) [Barnes and Sharp (1999)].

At least five isoforms of the $5-\mathrm{HT}_{1} \mathrm{R}$ have been identified $\left(5-\mathrm{HT}_{1 \mathrm{~A}}, 5-\mathrm{HT}_{1 \mathrm{~B}}, 5-\mathrm{HT}_{1 \mathrm{D}}, 5-\right.$ $\mathrm{HT}_{1 \mathrm{E}}$, and $5-\mathrm{HT}_{1 \mathrm{~F}}$ ) that are coupled to inhibitory $\mathrm{G}_{\mathrm{i}}$-proteins leading to inhibition of adenylyl cyclases (AC). The three isoforms of $5-\mathrm{HT}_{2} \mathrm{Rs}\left(5-\mathrm{HT}_{2 \mathrm{~A}}, 5-\mathrm{HT}_{2 \mathrm{~B}}\right.$, and $\left.5-\mathrm{HT}_{2 \mathrm{C}}\right)$ are coupled to hetero-trimeric $\mathrm{G}_{\mathrm{q}}$-proteins that are linked to the phospholipase- $\mathrm{C}$ (PLC). The effector system for the two isoforms of $5-\mathrm{HT}_{5} \mathrm{Rs}$, the $5-\mathrm{HT}_{5 \mathrm{~A}} \mathrm{R}$ and the 5$\mathrm{HT}_{5 \mathrm{~B}} \mathrm{R}$, remains to be clarified, but there is evidence that the $5-\mathrm{HT}_{5 \mathrm{~A}} \mathrm{R}$ is negatively coupled to the AC [Hurley et al. (1998)]. Other 5-HTR subfamilies, including the 5$\mathrm{HT}_{4} \mathrm{R}, 5-\mathrm{HT}_{6} \mathrm{R}$, and $5-\mathrm{HT}_{7} \mathrm{R}$, are linked to stimulating $\mathrm{G}_{\mathrm{s}}$-proteins mediating an increase of ACs and consequently an increase of the intracellular cAMP concentration ([cAMP $]_{i}$ ) [Barnes and Sharp (1999), Hoyer et al. (2002), Kroeze et al. (2002)] (fig. 4). 


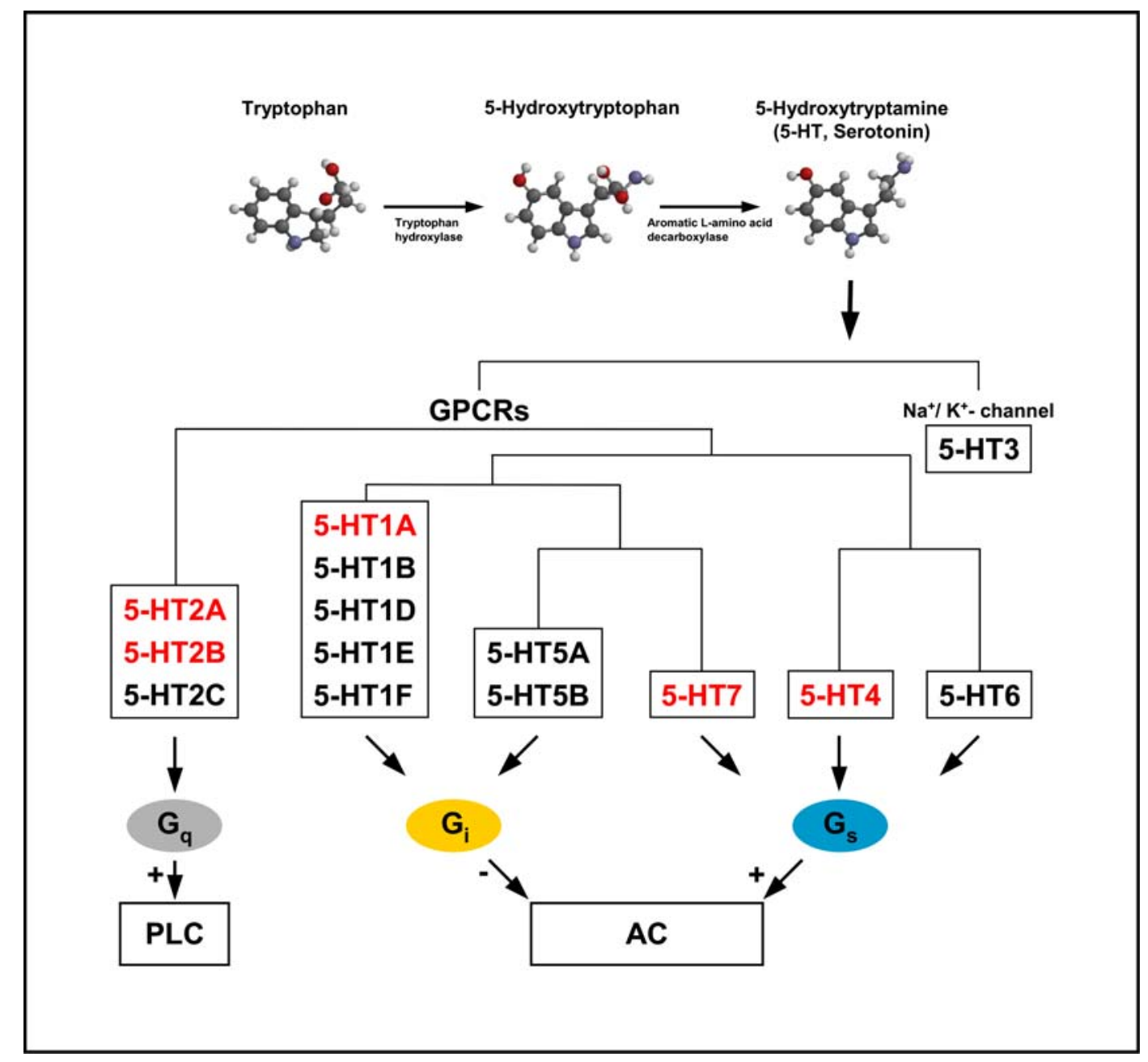

Figure 4. Phylogenetic tree of the serotonin receptor (5-HTR) family: serotonin (5-hydroxytryptamine, 5-HT), which is synthesised from the amino acid tryptophan, operates through at least 14 different receptor isoforms [Barnes and Sharp (1999)]. The receptor superfamily is subdivided into seven families. Except for the 5- $\mathrm{HT}_{3}$ receptor, which is a ligand-gated $\mathrm{Na}^{+} / \mathrm{K}^{+}$-ion-channel, all other 5$\mathrm{HT}$ receptors belong to the class of G-protein-coupled receptors. The receptors which were analysed in this thesis are marked with red colour. Abbreviations: hetero-trimeric guanine-nucleotide-binding Gprotein $\left(G_{q}, G_{i}\right.$, or $\left.G_{s}\right)$, adenylyl cyclase $(A C)$, phospholipase $C(P L C)$, G-protein-coupled receptors (GPCRs), activation (+), inhibition (-).

\subsubsection{Serotonin $1 \mathrm{~A}$ receptor isoform}

The isoforms of $5-\mathrm{HT}_{1} \mathrm{Rs}$ are distinguished by their different pharmacology and distribution pattern within the brain [Hoyer et al. (1994)]. The 5-HT $1 \mathrm{~A} R$, the first fully sequenced 5-HTR [Kobilka et al. (1987)], couples to a variety of effectors through pertussis-toxin sensitive hetero-trimeric $\mathrm{G}$-proteins of the $\mathrm{G}_{\mathrm{i} / \mathrm{o}}$-family [Barnes and Sharp (1999), Raymond et al. (1999)]. Receptor-dependent activation of $\mathrm{G}_{\alpha i}$-Subunits results in inhibition of $A C s$ and a subsequent decrease of the $[C A M P]_{i}$. Stimulation of $5-\mathrm{HT}_{1 \mathrm{~A}} \mathrm{R}$ also leads to $\mathrm{G}_{\beta \gamma}$-mediated activation of $\mathrm{K}^{+}$-channels and closure of $\mathrm{Ca}^{2+}$ channels [Andrade and Nicoll (1987), Zgombick et al. (1989)]. Within the brain, 5$\mathrm{HT}_{1 \mathrm{~A}} \mathrm{Rs}$ are predominantly expressed in the hippocampus, lateral septum, and cortical regions [Barnes and Sharp (1999)] as well as in brainstem regions like nuclei raphé and hypoglossal nuclei. The $5-\mathrm{HT}_{1 \mathrm{~A}} \mathrm{R}$ represents the classical 'autoreceptor' on presynaptic terminals [Hamon (1997)] inhibiting presynaptic transmitter release and depressing synaptic transmission [Koyama et al. (2002)]. At the postsynaptic site, it induces membrane hyperpolarisation mostly through activation of inwardly 
rectifying $\mathrm{K}^{+}$-channels [Richter et al. (1997)] or inhibition of $\mathrm{Ca}^{2+}$-channels [McAllister -Williams and Kelly (1995)]. In addition to 5-HT autoreceptors, recent reports indicate that 5-HT neurones are also regulated by postsynaptic 5-HT receptors. For example, experiments showing that cortical lesions attenuate the inhibitory effect of $5-\mathrm{HT}_{1 \mathrm{~A}} \mathrm{R}$ agonists on 5-HT cell firing suggest that postsynaptic 5- $\mathrm{HT}_{1 \mathrm{~A}} \mathrm{Rs}$ in cortical regions regulate the firing of dorsal raphé nucleus (DRN) 5-HT neurones [Ceci et al. (1994), Hajós et al. (1999)]. A projection from the medial prefrontal cortex to the DRN has been proposed as the underlying anatomical substrate [Hajós et al. (1998), Varga et al. (2001)].

The clinical relevance of the $5-\mathrm{HT}_{1 \mathrm{~A}} \mathrm{Rs}$ became evident in pharmacological studies demonstrating high efficacy on anxiety- and depression-related mood states. Partial agonists of $5-\mathrm{HT}_{1 \mathrm{~A}} \mathrm{Rs}$, such as buspirone, are effective as anti-anxiety agents, while antagonists of $5-\mathrm{HT}_{1 \mathrm{~A}} \mathrm{R}$ accelerated the antidepressant action of selective serotonin reuptake inhibitors (SSRIs) [Artigas et al. (1996)]. Furthermore, mice lacking the gene encoding for the $5-\mathrm{HT}_{1} \mathrm{R}$ display increased anxiety behaviour and stress response, confirming the important role of the $5-\mathrm{HT}_{1} \mathrm{R}$ for the regulation of mood, emotions, and sexual motivation [Parks et al. (1998)].

In the central respiratory network, the $5-\mathrm{HT}_{1 \mathrm{~A}} \mathrm{R}$ represents the most extensively expressed and analysed 5-HTR subtype. Direct applications of serotonin or its analogues to respiratory neurones effectively depress their excitability [Bonham (1995), Lalley et al. (1994a), Lalley et al. (1995), Lindsey and Feldman (1993)]. Therefore, it was not surprising that attempts in pharmacological treatment of respiratory disturbances, such as apneusis, which is defined as an abnormal respiratory pattern consisting of an arrest at inspiration and prolonged breath holding, with 5- $\mathrm{HT}_{1 \mathrm{~A}} \mathrm{R}$ agonists were successful. Application of $5-\mathrm{HT}_{1 \mathrm{~A}} \mathrm{R}$ agonists was also effective to recover apneustic discharges as they occur during early stages of hypoxia or ischemia after systemic administration of NMDA-type glutamate receptor blockers [Feldman et al. (1992)] or after application of barbiturates [Lalley et al. (1994b)]. Under these conditions, the 5- $\mathrm{HT}_{1 \mathrm{~A}} \mathrm{R}$-agonist 8-OH-DPAT shortened prolonged apneustic inspiratory discharges to re-establish a normal respiratory rhythm. Identical anti-apneustic effects were achieved with buspirone which was found to be remarkably effective in the treatment of apneustic disturbances occurring after surgical resection of an astrocytoma localised within ponto-medullary regions [Wilken et al. (1997)]. Furthermore, Sahibzada et al. (2000) demonstrated that application of 8-OH-DPAT overcomes successfully opioid-induced respiratory depression.

\subsubsection{Serotonin $2 A$ and $2 B$ receptor isoforms}

The 5- $\mathrm{HT}_{2}$ receptor subfamily includes the $5-\mathrm{HT}_{2 \mathrm{~A}}, 5-\mathrm{HT}_{2 \mathrm{~B}}$, and $5-\mathrm{HT}_{2 \mathrm{C}}$ receptor isoforms, which couple preferentially to the $\mathrm{G}_{\mathrm{q} / 11}$-protein. The resulting activation of phospholipase C (PLC) leads to an increase of hydrolysis of inositol phosphates and elevation of cytosolic [ $\mathrm{Ca}^{2+}$ ] [Hoyer et al. (1994), Hoyer et al. (2002)]. 5- $\mathrm{HT}_{2} \mathrm{Rs}$ are located postsynaptically [Cornea-Hebert et al. (1999), Palacios et al. (1990), Verge and Calas (2000)], and there is evidence that these receptors may also regulate $5-\mathrm{HT}$ neurotransmission [Garratt et al. (1991), Wright et al. (1990)]. 5- $\mathrm{HT}_{2 \mathrm{~A}} \mathrm{R}$ expression was found in the neocortex, entorhinal and pyriform cortex, claustrum, caudate nucleus, nucleus accumbens, olfactory tubercle, hippocampus, and the cerebellum [Barnes and Sharp (1999), Geurts et al. (2002)], whereas 5- $\mathrm{HT}_{2 \mathrm{~B}} \mathrm{R}$ expression was described for the neocortex, cerebellum, dorsal hypothalamus, and medial amygdala 
[Duxon et al. (1997)]. The $5-\mathrm{HT}_{2 \mathrm{~B}} \mathrm{R}$ is an important regulator of embryonic development. Inactivation of the $5-\mathrm{HT}_{2 \mathrm{~B}} \mathrm{R}$ gene leads to partial embryonic and early neonatal death in mice [Negibil et al. (2000)]. However, evidence for a functional role of 5$\mathrm{HT}_{2 \mathrm{~B}} \mathrm{Rs}$ within the central nervous system is sparse. So far, the $5-\mathrm{HT}_{2 \mathrm{~B}} \mathrm{R}$ has been implicated in neurobiological mechanisms of anxiety, schizophrenia, autism, migraine, and spreading depression [Baxter et al. (1994), Kennett et al. (1996)]. Outside the brain, the $5-\mathrm{HT}_{2 \mathrm{~B}} \mathrm{R}$ is probably involved in the aetiology of cardiomyopathy [Nebigil et al. (2001)] and pulmonary hypertension [Launay et al. (2002)].

The expression and function of the $5-\mathrm{HT}_{2 \mathrm{~B}} \mathrm{R}$ in the respiratory system has not been investigated so far. In contrast, for the $5-\mathrm{HT}_{2 \mathrm{~A}} \mathrm{R}$ it has been shown that ionophoretical application of $5-\mathrm{HT}_{2 \mathrm{~A}} \mathrm{R}$-agonists, like $\alpha$-methyl-5-HT, directly to respiratory neurones accelerates their activity [Lalley et al. (1995)].

\subsubsection{Serotonin 4 receptor isoform}

The $5-\mathrm{HT}_{4} \mathrm{R}$, firstly described as a serotonin receptor stimulating the AC in cultured collicular neurones [Dumuis et al. (1988)] and guinea pig brain [Bockaert et al. (1990)], is also localised in basal ganglia, hippocampus, olfactory tubercle and limbic structures [Compan et al. (1996), Reynolds et al. (1995)]. The 5-HT $\mathrm{R}$ contributes to the control of transmitter secretion, facilitation of cognitive performances and also anxiety [Barnes and Sharp (1999)]. Outside the brain, 5- $\mathrm{HT}_{4} \mathrm{Rs}$ were found along the gastrointestinal tract, from the oesophagus to the ileum and colon [Borman and Burleigh (1993), Borman and Burleigh (1996), Budhoo et al. (1996)]. They are also present in the urinary bladder, in the adrenal glands, and in the myocardium [Bach et al. (2001), Eglen et al. (1995)]. Such wide distribution of $5-\mathrm{HT}_{4} \mathrm{Rs}$ is paralleled by the existence of different C-terminal splice-variants [5- $\mathrm{HT}_{4(\mathrm{a})}-4(\mathrm{~h}) \mathrm{R}$ ] [Bender et al. (2000), Blondel et al. (1998)]. The 5- $\mathrm{HT}_{4}$ receptor isoforms are positively coupled to the $\mathrm{AC}$ through a $\mathrm{G}_{\mathrm{s}}$-protein. Recently, it has been shown that the $5-\mathrm{HT}_{4(\mathrm{~b})} \mathrm{R}$ isoform is also coupled to $\mathrm{G}_{\alpha i / 0}$-subunits [Pindon et al. (2002)]. Receptor-mediated increase in cAMP levels leads to phosphorylation of a number of target proteins, including voltagegated channels [Bickmeyer et al. (2002), Cardenas et al. (1997)]. The hetero-trimeric $\mathrm{G}_{\alpha 13}$-protein represents an additional interaction partner of the $5-\mathrm{HT}_{4(\mathrm{a})} \mathrm{R}$, and activation of $5-\mathrm{HT}_{4} \mathrm{R} / \mathrm{G}_{\alpha 13}$-signalling results in activation of gene transcription, neuriteretraction, and cell-rounding through the small GTPases of the RhoA-protein family [Ponimaskin et al. (2002)]. Moreover, the activity of the protein kinase A can also be increased independently from the cAMP by an A-kinase-anchoring protein 110 (AKAP 110) ('CAMP-independent' pathway) [Niu et al. (2001)]. The hitherto discovered interaction partners for the $5-\mathrm{HT}_{4} \mathrm{R}$ represent the molecular basis for the complexity of the $5-\mathrm{HT}_{4} \mathrm{R}$ signal transduction.

Several 5- $\mathrm{HT}_{4} \mathrm{R}$-specific antagonists [Langlois and Fischmeister (2003)] have been shown to be highly potent in the treatment of atrial fibrillation, and the involvement of $5-\mathrm{HT}_{4} \mathrm{R}$ in the processing of the amyloid precursor protein has led to the suggestion that $5-\mathrm{HT}_{4} \mathrm{R}$ agonists may be beneficial for the treatment of memory disorders such as Alzheimer's disease [Lezoualc'h and Robert (2003)]. Clinical application of 5$\mathrm{HT}_{4} \mathrm{R}$ agonists has been performed only to treat disturbances of the gastrointestinal tract so far, such as gastroparesis, dyspepsia, gastro-oesophageal reflux, and the irritable bowel syndrome [Quigley (2000)]. 
However, there is a lack of information about the expression and function of the 5$\mathrm{HT}_{4} \mathrm{R}$ in the respiratory system.

\subsubsection{Serotonin 7 receptor isoform}

The $5-\mathrm{HT}_{7} \mathrm{R}$, one of the most recently described members of the $5-\mathrm{HT}$ receptor family, has been cloned in several species, including humans [Barnes and Sharp (1999)]. The cDNA encoding the receptor contains two introns, one located in the second intracellular loop [Bard et al. (1993), Shen et al. (1993)], and the second in the predicted C-terminus [Ruat et al. (1993)]. So far, alternate splicing of the second intron has been reported to generate four $5-\mathrm{HT}_{7}$ receptor isoforms $\left(5-\mathrm{HT}_{7 \mathrm{~A}}-{ }_{7 \mathrm{D}} \mathrm{R}\right)$, which differ in their C-termini [Heidmann et al. (1997), Vanhoenacker et al. (2000)]. However, these isoforms have not been shown to differ in their pharmacology, signal transduction or tissue distribution [Heidmann et al. (1998), Jasper et al. (1997)]. The $5-\mathrm{HT}_{7} \mathrm{R}$ is positively coupled to the AC through a $\mathrm{G}_{\mathrm{s}}$-protein. Furthermore, it has been shown that the $5-\mathrm{HT}_{7(\mathrm{a})} \mathrm{R}$ possibly activate not only typical $\mathrm{G}_{\mathrm{s}}$-protein sensitive adenylyl cyclase $A C-V$, but also two $\mathrm{Ca}^{2+} /$ calmodulin-regulated $A C$ isoforms, $A C-I$ and AC-VIII [Baker et al. (1998)]. Additionally, it may lead to $\mathrm{G}_{\mathrm{s}}$-mediated, Rasdependent activation of the extracellular signal-regulated kinases (ERK) 1 and 2 [Norum et al. (2003)]. The 5- $\mathrm{HT}_{7} \mathrm{R}$ exhibits a high affinity for 5-carboxamido-tryptamine (5-CT), a considerable affinity for the 5- $\mathrm{HT}_{1 \mathrm{~A}} \mathrm{R}$-agonist 8-OH-DPAT, and a low affinity for buspirone. Recently developed antagonists specific for the $5-\mathrm{HT}_{7} \mathrm{R}$, such as SB 269970 [Thomas et al. (1999)], allowing for more precise characterisation of the $5-\mathrm{HT}_{7} \mathrm{R}$ functions. The $5-\mathrm{HT}_{7} \mathrm{R}$ has been detected in the thalamus, hypothalamus, hippocampus and cortex, with highest expression levels occurring in the intralaminar and midline nuclei of the thalamus [Heidmann et al. (1998), Vizuete et al. (1997)]. Outside the brain, receptor expression was found in smooth muscle cells of blood vessels and in the gastrointestinal tract [Vanhoenacker et al. (2000)].

The possible clinical relevance of the $5-\mathrm{HT}_{7} \mathrm{R}$ is reflected by its association with a number of physiological and pathophysiological phenomena. The receptor seems to be important for serotonin-induced phase shifting of the mammalian circadian rhythm that is controlled by the suprachiasmatic nucleus of the hypothalamus [Lovenberg et al. (1993)], while a decrease of $5-\mathrm{HT}_{7} \mathrm{R}$ expression in the dorsal raphé nuclei was presumed to be involved in age-dependent changes of the circadian timing [Duncan et al. (1999)]. Furthermore, on the basis of mice lacking the $5-\mathrm{HT}_{7} \mathrm{R}$, Hedlund et al. (2003) could demonstrate that serotonin-induced hypothermia is mediated by the 5$\mathrm{HT}_{7} \mathrm{R}$.

However, the expression and physiological role of the $5-\mathrm{HT}_{7} \mathrm{R}$ in the respiratory system has not been investigated so far. 


\subsection{Aim of this work}

The present work aims at investigating the expression and functional role of the 5$\mathrm{HT}_{1 \mathrm{~A}}, 5-\mathrm{HT}_{2 \mathrm{~A}}, 5-\mathrm{HT}_{2 \mathrm{~B}}, 5-\mathrm{HT}_{4(\mathrm{a})}$, and $5-\mathrm{HT}_{7}$ receptor isoforms in the respiratory system. This project is subdivided into several working steps including:

(i) the production of specific poly- or monoclonal antibodies directed against the serotonin $2 \mathrm{~B}, 4(\mathrm{a})$, and 7 receptor isoforms since there were no specific antibodies commercially available,

(ii) the analysis of $5-\mathrm{HT}_{1 \mathrm{~A}}, 5-\mathrm{HT}_{2 \mathrm{~A}}, 5-\mathrm{HT}_{2 \mathrm{~B}}, 5-\mathrm{HT}_{4(\mathrm{a})}$, and $5-\mathrm{HT}_{7}$ receptor isoform expression within the respiratory system particularly in the preBötzinger complex which is essential for respiratory rhythm generation,

(iii) the analysis of co-expression of 5-HT receptors which might operate on convergent signal transduction pathways,

(iv) the analysis of co-expression of $5-\mathrm{HT}$ receptors with $\mu$-opioid receptors which mainly mediate opioid-induced anti-nociceptive effects,

(v) physiological tests to demonstrate whether selective activation of these 5$\mathrm{HT}$ receptors stimulates respiratory activity,

(vi) to test whether the possible excitatory effects can be utilised to recover opioid-induced respiratory depression,

(vii) to test whether or not the opioid-induced analgesia continues after recovery of respiratory depression, and finally

(viii) the investigation of $5-\mathrm{HT}_{4(\mathrm{a})}$ and $\mu$-opioid receptor expression during development to obtain informations about their neurotrophic function within the respiratory system.

A major goal of this thesis is to test possible convergent signal transduction pathways of 5-HT receptors involved in the neuromodulatory control of the respiratory centre. Such convergent receptor signalling might provide new strategies for the future to treat instabilities of respiratory rhythm generation. 


\section{Material and Methods}

\subsection{Material}

\subsubsection{Reagents and chemicals}

\begin{tabular}{|c|c|c|}
\hline Product & Manufacturer & Order number \\
\hline \multicolumn{3}{|c|}{ Anaesthetic and antibiotic agents } \\
\hline Pentobarbital (Nembutal ${ }^{\circledR}$ ) & Sanofi & \\
\hline Ether & Sigma & 443549 \\
\hline Penicillin V & Sigma & 46616 \\
\hline Ampicillin & Sigma & A-9393 \\
\hline Penicillin-Streptomycin Solution (100x) & Sigma & P0781 \\
\hline Tetracyclin & Sigma & $\mathrm{T}-7660$ \\
\hline Carbenicillin & Sigma & C-1389 \\
\hline \multicolumn{3}{|c|}{ DNA markers } \\
\hline pBR322 DNA/Alw44I/Mval & MBI Fermentas & SM0211 \\
\hline lambda DNA/Bst Ell & Biomol & 51589 \\
\hline 100 bp-DNA ladder equalised & Roth & T833.1 \\
\hline \multicolumn{3}{|c|}{ Protein markers } \\
\hline Precision Plus Protein ${ }^{\mathrm{TM}}$ Standards & Bio-Rad & $161-0363$ \\
\hline Prestained MWM & MBI Fermentas & SM0441 \\
\hline LMW Marker & Amersham Pharmacia & $17-0446-01$ \\
\hline \multicolumn{3}{|c|}{ Affinitychromatography } \\
\hline Protein A-Sepharose ${ }^{\circledR} 4 \mathrm{~B}$ & Sigma & P 9424 \\
\hline CNBr-activated Sepharose ${ }^{\circledR} 4 \mathrm{~B}$ & Amersham Pharmacia & $17-0430-01$ \\
\hline \multicolumn{3}{|c|}{ Restriction endonucleases, vectors, and plasmides } \\
\hline Kpn I & Sigma & R 1258 \\
\hline Sac I & Sigma & R 5268 \\
\hline pBluescript SK II (+/-) phagemid & Stratagene & 212205 \\
\hline DIG RNA Labelling Mix & Roche & 1277073 \\
\hline $5-\mathrm{HT}_{4(\mathrm{a})} \mathrm{R}$ & \multirow{6}{*}{\multicolumn{2}{|c|}{ PD Dr. Ponimaskin }} \\
\hline 5-HT $4(a) R-G F P$ & & \\
\hline $5-\mathrm{HT}_{7} \mathrm{R}$ & & \\
\hline 5-HT7 $\mathrm{R}-\mathrm{GFP}$ & & \\
\hline 5-HT 7 R-YFP & & \\
\hline 5-HT 7 R-HA & & \\
\hline
\end{tabular}




\begin{tabular}{|c|c|c|}
\hline \multicolumn{3}{|c|}{ Cell culture mediums and chemicals } \\
\hline Antibiotic/fungicidal (100x) & PAA & P11-002 \\
\hline Phenol red & Sigma & P-4758 \\
\hline Sodium pyruvate & Biochrom & L0473 \\
\hline RPMI-1640 & Biochrom & T121-50 \\
\hline L-glutamine $200 \mathrm{mM}$ & Invitrogen & $25030-024$ \\
\hline FCS & PAN Biotech & 3702-P2306 \\
\hline Lipofectamine $^{\mathrm{TM}} 2000$ & Invitrogen & $11668-019$ \\
\hline Trypsine solution (10x) & Invitrogen & $15090-046$ \\
\hline DMEM & Gibco/Invitrogen & 41966-029 \\
\hline Human IL-6 & Serva & 47236 \\
\hline \multicolumn{3}{|c|}{ RT-PCR } \\
\hline PANScript red DNA Polymerase & PAN Biotech & MB-1100600 \\
\hline Taq DNA polymerase & Invitrogen & $10342-020$ \\
\hline Red $\mathrm{Taq}^{\mathrm{TM}}$ DNA polymerase & Sigma & D-5684 \\
\hline dNTP set & Eppendorf & 0032003.206 \\
\hline SuperScript ${ }^{\mathrm{TM}}$ first-strand synthesis kit & Invitrogen & $11904-018$ \\
\hline Deoxyribonuclease I & Invitrogen & $18068-015$ \\
\hline AccuPrime $^{\mathrm{TM}}$ SuperMix II & Sigma & $12341-020$ \\
\hline GenElute $^{\mathrm{TM}}$ mammalian total RNA kit & Sigma & RTN70 \\
\hline \multicolumn{3}{|c|}{ General chemicals, plastic products, and miscellaneous reagents } \\
\hline 2-propanol & Merck & 1.09634 .2500 \\
\hline Acetic acid (100\%) & Roth & 3738.2 \\
\hline 2-mercaptoethanol & Merck & 8.05740 .0250 \\
\hline $\mathrm{HCl}(32 \%)$ & Merck & 1.00319 .2500 \\
\hline $\mathrm{NaH}_{2} \mathrm{PO}_{4} * \mathrm{H}_{2} \mathrm{O}$ & Merck & 6346 \\
\hline $\mathrm{Na}_{2} \mathrm{HPO}_{4} * 12 \mathrm{H}_{2} \mathrm{O}$ & Merck & 1.06579 .5000 \\
\hline $\mathrm{NaHCO}_{3}$ & Merck & 1.06329 .1000 \\
\hline $\mathrm{CH}_{3} \mathrm{COONa} * 3 \mathrm{H}_{2} \mathrm{O}$ & Merck & 1.06265 .1000 \\
\hline $\mathrm{Na}_{2} \mathrm{CO}_{3}$ & Merck & 1.06392 .1000 \\
\hline $\mathrm{NaN}_{3}$ & Merck & 1.06688 .0250 \\
\hline $\mathrm{NaOH}$ & Merck & 1.06498 .1006 \\
\hline $\mathrm{LiCl}$ & Merck & 1.05679 .0250 \\
\hline $\mathrm{MgSO}_{4} * 7 \mathrm{H}_{2} \mathrm{O}$ & Fluka & 63138 \\
\hline $\mathrm{H}_{2} \mathrm{O}_{2}(35 \%)$ & Merck & 1.08556 .9025 \\
\hline $\mathrm{Na}_{2} \mathrm{HPO}_{4} * 2 \mathrm{H}_{2} \mathrm{O}$ & Fluka & 71638 \\
\hline $\mathrm{MgCl}_{2} * 6 \mathrm{H}_{2} \mathrm{O}$ & Riedel-de Haen & 31413 \\
\hline $\mathrm{CaCl}_{2} * 2 \mathrm{H}_{2} \mathrm{O}$ & Merck & 2382 \\
\hline $\mathrm{CuSO}_{4} * 5 \mathrm{H}_{2} \mathrm{O}$ & Merck & 2790 \\
\hline
\end{tabular}




\begin{tabular}{|c|c|c|}
\hline $\mathrm{CoCl}_{2} * 6 \mathrm{H}_{2} \mathrm{O}$ & Sigma & C 8661 \\
\hline ABTS & Sigma & A1888 \\
\hline $\mathrm{Na}$-EDTA & Serva & 11280 \\
\hline TRIS & Roth & 4855.2 \\
\hline PEG-4000 & Sigma & 95904 \\
\hline $\mathrm{NaCl}$ & Roth & 3957.2 \\
\hline SDS & Serva & 20760 \\
\hline Glycine & Roth & 3908.3 \\
\hline Ponceau S & Sigma & P 7170 \\
\hline BSA fraction $V$ & PAA & K 41-012-50 \\
\hline Tween ${ }^{\circledR} 20$ & Roth & 9127.1 \\
\hline Tris & Roth & 4855.2 \\
\hline TCA & Merck & 1.00807 .1000 \\
\hline Triton ${ }^{\circledR} \mathrm{X}-100$ & Sigma & Т 8787 \\
\hline Glycerol & Sigma & G 7757 \\
\hline Serva blue $\mathrm{R}$ & Serva & 35051 \\
\hline Folin-Ciocalteu's phenol reagent & Sigma & F 9252 \\
\hline Bromophenol blue & Merck & 8122 \\
\hline $\mathrm{NaCl}$ & Roth & 3957.2 \\
\hline Hybond-N nylon membrane & Amersham Pharmacia & RPN303N \\
\hline Whatman filter paper & Schleicher and Schuell & \\
\hline BioMax MR X-ray film & Kodak & V 8929655 \\
\hline acetone & Roth & 9372.1 \\
\hline TiterMax $^{\mathrm{TM}}$ Gold adjuvant & Sigma & T 2684 \\
\hline complete Freund's adjuvant & Sigma & F 5881 \\
\hline incomplete Freund's adjuvant & Sigma & F 5506 \\
\hline N-ethylmaleimide & Sigma & E 3876 \\
\hline $\mathrm{KLH}$ & Sigma & H 7017 \\
\hline DMF & Sigma & D 4551 \\
\hline Centriprep YM-3 & Millipore & 4302 \\
\hline Centriprep YM-10 & Millipore & 4321 \\
\hline Gelatine & Difco & 0143.17 .9 \\
\hline Ethidium bromide & Merck & 1.11608 .0030 \\
\hline DMSO & Sigma & D 2650 \\
\hline Methanol > 99\% & Roth & 4627.5 \\
\hline Potassium-sodiumtartrate tetrahydrate & Fluka & 60412 \\
\hline TEMED p. a. & Roth & 2367.3 \\
\hline APS & Bio-Rad & $161-0700$ \\
\hline DAB & Sigma & D 5637 \\
\hline DTT & Serva & 20710 \\
\hline
\end{tabular}




\begin{tabular}{|c|c|c|}
\hline DTE & Serva & 20697 \\
\hline Paraformaldehyde & Sigma & P 6148 \\
\hline Potassium dichromate & Sigma & P 6435 \\
\hline Kernechtrot (Certistain ${ }^{\circledR}$ ) & Merck & 1.15939 \\
\hline Saponin & Sigma & 84510 \\
\hline Ethanol $>96 \%$ & Nordbrand Nordhausen & 410 \\
\hline Protease inhibitor cocktail & ICN & 158837 \\
\hline PMSF & Sigma & P 7626 \\
\hline Servapor $^{\circledR}$ dialysis tubing & Serva & 44139 \\
\hline S-Monovette ${ }^{\circledR} 7.5 \mathrm{ml}$ & Sarstedt & 01.1601 \\
\hline Immunoplates (MaxiSorp) & Nunc & 430341 \\
\hline SonicSeal ${ }^{\circledR}$ slide wells & Nunc & 138121 \\
\hline DePeX & Serva & 18243.02 \\
\hline FMM & Dako & S3023 \\
\hline
\end{tabular}

\subsubsection{Primer for conventional RT-PCR}

\begin{tabular}{c|c|c}
\hline Target & Forward primer $\left(\mathbf{5}^{\prime} \rightarrow \mathbf{3}^{\prime}\right)$ & Reverse primer $\left(\mathbf{5}^{\prime} \rightarrow \mathbf{3}^{\prime}\right)$ \\
\hline $5-\mathrm{HT}_{2 \mathrm{~A}} \mathrm{R}$ & ACCTTGTGTGTGGTGACCT & TAGGCCAATGCTGGTATAGT \\
\hline $5-\mathrm{HT}_{2 \mathrm{~B}} \mathrm{R}$ & CTGGTTATTCTGGCTGTTTC & GACCACATCAGCCTCTATTC \\
\hline $5-\mathrm{HT}_{4(\mathrm{a}) \mathrm{R}}$ & CCAAGGCAGCCAAGACT & TAGTAACCTGTTCATGCAGACACA \\
\hline \multirow{2}{*}{$5-\mathrm{HT}_{7} \mathrm{R}$} & CTGGTTATTCTGGCTGTTTC & GACCACATCAGCCTCTATTC \\
\cline { 2 - 3 } & GTTAGTGTCACCGACCTCAT & CGGCCTTGTAAATCTGATAG \\
\hline NK-1R & GCTCTCTTCGCCAGTATCTA & TAGACCTGCTGGATGAACTT \\
\hline Nestin & GTGCGTGACTACCAGGAG & TCTCAAGGGTATTAGGCAAG \\
\hline$\mu$-OR & TTCTGCATTGCTTTGGGTTACACG & CTGACAGCAACCTGATTCCACGTA \\
\hline$\beta$-Actin & GATATCGCTGCGCTCGTCGTC & CCTCGGGGCATCGGAACC \\
\hline
\end{tabular}

\subsubsection{Primer for single-cell RT-PCR}

\begin{tabular}{c|c|c}
\hline Target & Forward primer $\left(\mathbf{5}^{\prime} \rightarrow \mathbf{3}^{\prime}\right)$ & Reverse primer $\left(\mathbf{5}^{\prime} \rightarrow \mathbf{3}^{\prime}\right)$ \\
\hline $5-\mathrm{HT}_{4} \mathrm{R}$ & CTGTAATGGACAGACTTGA & GGCAAAACATCTCCCCATAA \\
\hline $5-\mathrm{HT}_{4(\mathrm{a})} \mathrm{R}$ & CCAAGGCAGCCAAGACT & TAGTAACCTGTTCATGCAGACACA \\
\hline $5-\mathrm{HT}_{4(\mathrm{~b})} \mathrm{R}$ & CCAAGGCAGCCAAGACT & TTGCCTCATGCTCTTGGAA \\
\hline $5-\mathrm{HT}_{1 \mathrm{~A}} \mathrm{R}$ & TCTGCCCAGCGAGGCTGGTC & GATCCTGTAGCCTCGACTG \\
\hline \multirow{2}{*}{$5-\mathrm{HT}_{7} \mathrm{R}$} & GAGTCGAGAAAGTT- & AGGTACCTGTCAAT- \\
& GTGATCGGCTCCA & GCTGATCACGCAC \\
\hline$\mu-O R$ & TTCTGCATTGCTTTGGGTTACACG & CTGACAGCAACCTGATTCCACGTA \\
\hline NK-1R & CAGGACTTATGAGAAAGCGT & AGATCTGGGTTGATGTAGGG \\
\hline$\beta-a c t i n$ & TGGCCTTAGGGTTGCAGGGGG & GTGGGCCGCTCTAGGCACCA \\
\hline
\end{tabular}




\subsubsection{Peptides for immunisation}

Manufacturer: ThermoHybaid

\begin{tabular}{|c|c|c|}
\hline Target & Region & Peptidesequence \\
\hline \multirow{3}{*}{ 5- $\mathrm{HT}_{4(\mathrm{a})}$ receptor } & C-terminus & VLHSGHHQELEKLPIHNDPC \\
\hline & C-terminus & HSGHHQELEKLPIHNDPESC \\
\hline & C-terminus & CHSGHHQELEKLPIHNDP \\
\hline \multirow{4}{*}{ 5- $\mathrm{HT}_{7}$ receptor } & $3^{\text {rd }}$ intracell. loop & KHERKNISSFKREQC \\
\hline & $3^{\text {rd }}$ intracell. loop & CKHERKNISSFKREQK \\
\hline & $3^{\text {rd }}$ intracell. loop & FSGFPRVQPESVISC \\
\hline & $3^{\text {rd }}$ intracell. loop & FPRVQPESVISLNGC \\
\hline \multirow{3}{*}{ 5- $\mathrm{HT}_{1 \mathrm{~A}}$ receptor } & $2^{\text {nd }}$ extracell. loop & DRSNPNECTISKC \\
\hline & $3^{\text {rd }}$ intracell. loop & VRQGEDADDATLEVIEC \\
\hline & $3^{\text {rd }}$ intracell. loop & AVGTPCANGAVRQGC \\
\hline 5- $\mathrm{HT}_{2 \mathrm{~B}}$ receptor & $2^{\text {nd }}$ intracell. loop & CAISLDRYIAIKKPIQ \\
\hline
\end{tabular}

\subsubsection{Antibodies and protein standards}

\begin{tabular}{|c|c|c|}
\hline Product & Manufacturer & Order number \\
\hline \multicolumn{3}{|c|}{ Primary antibodies } \\
\hline Guinea pig anti-5- $\mathrm{HT}_{1 \mathrm{~A}} \mathrm{R}$ & Chemicon & AB5406 \\
\hline Goat anti-5- $\mathrm{HT}_{1 \mathrm{~A}} \mathrm{R}$ & Santa Cruz & sc-1459 \\
\hline Rabbit anti-5-HT $7 \mathrm{R}$ & Acris & SP7003P \\
\hline Rabbit anti-5-HT $7 \mathrm{R}$ & Imgenex & IMG-368 \\
\hline Rabbit anti-5-HT 7 R & Oncogene & PC249L \\
\hline Goat anti-5-HT $7 \mathrm{R}(\mathrm{M}-15)$ & Santa Cruz & sc-19160 \\
\hline Goat anti-5- $\mathrm{HT}_{7} \mathrm{R}(\mathrm{S}-20)$ & Santa Cruz & sc-19158 \\
\hline Guinea pig anti- $\mu-O R-1$ & Chemicon & $\mathrm{AB} 1774$ \\
\hline Goat anti- $\mu-O R-1$ (C-20) & Santa Cruz & sc-7488 \\
\hline Guinea pig anti-NK-1R & Chemicon & AB5800 \\
\hline Rabbit anti-NK-1R & Chemicon & AB5060 \\
\hline Goat anti-ChAT & Chemicon & AB144P \\
\hline Mouse anti-GFAP (clone G-A-5) & \multicolumn{2}{|c|}{ Prof. Osborne, MPI for biophysical chemistry } \\
\hline Rabbit anti-GFAP & Dako & Z0334 \\
\hline Mouse anti-Neurofilament & \multicolumn{2}{|c|}{ Prof. Osborne, MPI for biophysical chemistry } \\
\hline Mouse anti-Nestin & DSHB, lowa & Rat-401 \\
\hline \multicolumn{3}{|c|}{ Antibodies for isotype-characterisation } \\
\hline Mouse anti-hamster Ig, $\kappa$ light chain & BD PharMingen & 550635 \\
\hline Mouse anti-hamster IgM & BD PharMingen & 554031 \\
\hline Mouse anti-hamster IgG & BD PharMingen & 554024 \\
\hline
\end{tabular}




\begin{tabular}{|c|c|c|c|}
\hline \multicolumn{4}{|c|}{ Protein standards } \\
\hline MBP & \multicolumn{2}{|l|}{ Sigma } & 2941 \\
\hline GFAP & \multicolumn{2}{|l|}{ Merck } & 345996 \\
\hline Neurofilaments & \multicolumn{2}{|l|}{ Sigma } & N 1022 \\
\hline \multicolumn{4}{|c|}{ Secondary antibodies } \\
\hline \multicolumn{2}{|c|}{ HRP-goat anti-guinea pig IgG } & Dianova & 106-035-008 \\
\hline \multicolumn{2}{|c|}{ HRP-goat anti-Syrian hamster IgG } & Dianova & $107-036-142$ \\
\hline \multicolumn{2}{|c|}{ HRP-donkey anti-goat IgG } & Dianova & $705-036-147$ \\
\hline \multicolumn{2}{|c|}{ HRP-goat anti-rabbit IgG } & Dianova & $111-035-144$ \\
\hline \multicolumn{2}{|c|}{ HRP-sheep anti-mouse IgG } & Dianova & $515-035-071$ \\
\hline \multicolumn{2}{|c|}{ TRITC-goat anti-Syrian hamster IgG } & Dianova & $107-026-142$ \\
\hline \multicolumn{2}{|c|}{ Rabbit anti-mouse Ig } & Dako & Z0109 \\
\hline \multicolumn{2}{|c|}{ Pig anti-rabbit Ig } & Dako & Z0196 \\
\hline \multicolumn{2}{|c|}{ Rabbit anti-goat Ig } & Dako & Z0454 \\
\hline \multicolumn{2}{|c|}{ PAP (rabbit) } & Dako & Z0113 \\
\hline \multicolumn{2}{|c|}{ PAP (mouse), monoclonal } & Dako & P0850 \\
\hline \multicolumn{2}{|c|}{ PAP (mouse), polyclonal } & Dako & $\mathrm{B} 0650$ \\
\hline \multicolumn{2}{|c|}{ PAP (guinea pig) } & Dianova & $623-005-024$ \\
\hline PAP & & Dako & B0157 \\
\hline Goat anti-Sy & & Dianova & 107-005-142 \\
\hline HRP-Strept & & Dako & K0377 \\
\hline Goat anti- & & Dianova & $106-005-008$ \\
\hline Alexa Fluor ${ }^{\circledR} 488 \mathrm{gc}$ & amster & Molecular Probes & $\mathrm{A} 21110$ \\
\hline Alexa Fluor $^{\circledR} 546$ go & amster & Molecular Probes & A21111 \\
\hline Alexa Fluor $^{\circledR} 647 \mathrm{go}$ & amster & Molecular Probes & A21451 \\
\hline Alexa Fluor ${ }^{\circledR} 488$ & $\lg G$ & Molecular Probes & A11001 \\
\hline Alexa Fluor ${ }^{\circledR} 555$ & $\lg G$ & Molecular Probes & A21422 \\
\hline Alexa Fluor ${ }^{\circledR} 647$ & $\lg G$ & Molecular Probes & A21235 \\
\hline Alexa Fluor ${ }^{\circledR} 488$ & $\lg G$ & Molecular Probes & A11008 \\
\hline Alexa Fluor ${ }^{\circledR} 555$ & $\lg G$ & Molecular Probes & A21428 \\
\hline Alexa Fluor ${ }^{\circledR} 647$ & $\lg G$ & Molecular Probes & A21244 \\
\hline Alexa Fluor ${ }^{\circledR} 488 \mathrm{gc}$ & $\operatorname{oig} \lg G$ & Molecular Probes & A11073 \\
\hline Alexa Fluor $^{\circledR} 555 \mathrm{gc}$ & $\operatorname{oig} \lg G$ & Molecular Probes & A21435 \\
\hline Alexa Fluor $^{\circledR} 647 \mathrm{gc}$ & $\operatorname{oig} \lg G$ & Molecular Probes & A21450 \\
\hline Alexa Fluor ${ }^{\circledR} 488$ & $\lg \lg G$ & Molecular Probes & A11055 \\
\hline Alexa Fluor $^{\circledR} 555$ & $\operatorname{tg} \lg$ & Molecular Probes & A21432 \\
\hline Alexa Fluor ${ }^{\circledR} 647$ & t IgG & Molecular Probes & A21447 \\
\hline
\end{tabular}




\subsubsection{Pharmacological substances}

\begin{tabular}{c|c|c}
\hline Product & Manufacturer & Order number \\
\hline$\alpha-$ methyl-5-HT & Tocris & 0557 \\
\hline Ketanserin & Tocris & 0908 \\
\hline BW 723C86 & Tocris & 1059 \\
\hline LY 272015 & Eli Lilly & 1080 \\
\hline 8-OH-DPAT & Tocris & W-108 \\
\hline WAY 100635 & Sigma & 1322 \\
\hline BIMU-8 & Boehringer Ingelheim & 1612 \\
\hline GR 113808 & Tocris & \\
\hline SB 269970 & Tocris & \\
\hline
\end{tabular}

\subsubsection{Animals and cell lines}

\begin{tabular}{c|c}
\hline Species & Supplier \\
\hline BALB/c mice & Charles River \\
\hline Syrian hamsters & Charles River \\
\hline Sprague Dawley rats & Charles River \\
\hline New Zealand White rabbits & Bioscience (Dr. Benli) \\
\hline Cell lines & PD Dr. Ponimaskin \\
\hline Mouse neuroblastoma cells (N1E-115) & PD Dr. Ponimaskin \\
\hline Insect cells (Sf.9) & Dept. of immunology \\
\hline Rat basophilic leucocytes (RBL) & Dept. of immunology \\
\hline Rat T-lymphocytoma cells (23B6) & Dept. of immunology \\
\hline Mouse myeloma P3 X 63-Ag 8.653 (653) &
\end{tabular}

\subsubsection{Apparatuses}

\begin{tabular}{c|c}
\hline Apparatus & Manufacturer \\
\hline Centrifuge 5415D & Eppendorf \\
\hline Thermomixer 5436 & Eppendorf \\
\hline Mastercycler Gradient & Eppendorf \\
\hline Bio Photometer & Eppendorf \\
\hline Rocking table WT12 & Biometra \\
\hline Crosslinker & Biometra \\
\hline Agagel Maxi & Biometra \\
\hline Minigel system & Biometra \\
\hline Multigel long system & Biometra \\
\hline Maxigel system & Biometra \\
\hline Hybridisation furnace & Biometra-Mytron \\
\hline Power supply, model 500 & Bio-Rad
\end{tabular}




\begin{tabular}{|c|c|}
\hline Genepulser I & Bio-Rad \\
\hline Novablot system & Amersham Pharmacia \\
\hline Power supply GPS 200/400 & Amersham Pharmacia \\
\hline Power supply ECPS 3000/150 & Amersham Pharmacia \\
\hline Biochrom 4060 Spectrometer & Pharmacia-LKB \\
\hline Microscope TELAVAL 31 & Zeiss \\
\hline $\begin{array}{c}\text { Confocal laser-scanning microscope } \\
\text { Meta-LSM } 510\end{array}$ & Zeiss \\
\hline Laminar flow DLF BSS6 & Clean Air \\
\hline Laminar flow DLF BSS4 & Clean Air \\
\hline Incubator aerated/ non aerated & Heraeus \\
\hline Varifuge RF & Heraeus \\
\hline Vortex Genie II & Bender and Hobein AG \\
\hline Programmable heating block KBT100-1P & HLC \\
\hline Pump 101U & Watson and Marlow \\
\hline Magnetic hotplate stirrer RCT basic & IKA Werke \\
\hline Microwave R-212 & Sharp \\
\hline Centrifuge RC-3B & Sorvall Instruments \\
\hline pH-Meter, InoLab & WTW \\
\hline Plate centrifuge $2-5$ & Sigma \\
\hline Heatable water bath & Kottermann \\
\hline Centrifuge Rotanta/RP & Hettich \\
\hline Speed Vac and Vapor Trap & Savant \\
\hline Minitherm CTT & Invitro Systems \\
\hline Shaking table, Rockomat & Tecnomara \\
\hline Thermomax microplate reader & MWG-Biotech (Molecular Devices) \\
\hline Shaker incubator & Dynatech \\
\hline Nunc-Immuno Wash 12 & Nunc \\
\hline Test-Tube-Rotator 34528 & Snijders \\
\hline Sunrise plate photometer & Tecan \\
\hline Thermocycler 60 & Bio-Med \\
\hline Balance 1205 MP & Sartorius \\
\hline Cryoslicer (Frigocut) & Reichert-Jung \\
\hline Flow cytometer, Coulter Epics XL & Beckman \\
\hline
\end{tabular}




\subsection{Methods}

\subsubsection{Production of poly- and monoclonal antibodies}

\subsubsection{Theory of poly- and monoclonal antibodies}

\subsection{Polyclonal antibodies}

For the production of polyclonal antibodies, the New Zealand White rabbit is the most commonly used laboratory animal [Harboe and Inglid (1983)]. Polyclonal antibodies produced by different B lymphocyte clones are isolated from the serum of an immunised animal. Polyclonal antisera normally contain large quantities of different antibodies with variable affinities for numerous antigens and epitopes and most of the immunoglobulin types. Since the pentameric structured IgM antibodies occur primarily after the first immunisation and are characterised by more non-specific binding than IgG antibodies, the laboratory animals are immunised additionally at least three or four times to eclipse the primary IgM- and to maximise the secondary IgG-response (hyperimmunisation). Antibodies bind to many discrete macromolecular sites called epitopes which generally consist of 6 - 12 amino acids [Harlow and Lane (1988)]. These antigenic determinants can be divided in linear and conformational epitopes [Arnon (1973), Crumpton (1974), Sela (1969)]. The great majority of antigenic determinants recognised by antibodies is of conformational origin [Laver et al. (1990)]. The epitope interacts with the specific antigen-binding site in the variable region of the immunoglobulin molecule (paratope). Immunogenic molecules normally bear many different epitopes which can be recognised by the immunoglobulins. The most intense immune responses are generated by epitopes that are most foreign in comparison with the same molecule of the host animal. The immunisation with short peptides after their coupling to immunogenic protein carriers can result in antibodies that react with the protein from which the peptide was derived [Lerner (1984), Walter et al. (1980)]. These so-called monospecific antibodies can be purified via affinity chromatography in which the peptide, which was used for the immunisation, is coupled to a matrix (e.g. sepharose). In spite of their limited specificity, these antibodies are polyclonal.

\subsection{Monoclonal antibodies}

In 1975 Köhler and Milstein discovered a technique that allows the cultivation of clonal populations of cells which secrete antibodies of a predefined specificity. The main principle of this method is based on the fusion of antibody secreting $B$ lymphocytes (spleen cells) of a hyperimmunised animal and immortal myeloma cells. $B$ cells removed from an immunised animal and cultured in-vitro die off quickly unless they are transformed and immortalised. One isolated and immortalised B cell clone from the polyclonal mixture is termed monoclonal. Monoclonal antibodies are produced by such a single $B$ cell clonal line which contains the capacity to produce an antibody recognising a single epitope. The hybridisation of a single $B$ cell precursor and a compatible immortal myeloma cell normally derived from the same species results in a hybridoma cell line producing monoclonal antibodies which bind to a single epitope [Köhler and Milstein (1975)]. When B lymphocytes and myeloma 
cells from different species are fused, the resulting hybridoma cells are termed hetero-hybridoma cells. Genetically modified cell lines derived from the myeloma cell line MOPC-21, which synthesise neither heavy nor light chains like the cell line X63Ag8.635 [Kearney et al. (1979)], are used for the production of antibody-secreting hybridomas when fused with spleen cells. After the fusion process, multiple cell types are present in the culture. The cells in their majority die immediately except for hybridomas and unfused myeloma cells. The myeloma cell line X63-Ag8.635 is deficient in the enzyme hypoxanthine guanine phosphoribosyl transferase (HGPRT). The fused cells are cultured in medium supplemented with hypoxanthine, aminopterine, and thymidine (HAT-medium). Aminopterin inhibits the biosynthetic pathway for nucleic acids. HGPRT deficient cells do not survive in HAT-medium due to the fact that the main and the salvage pathways are inhibited, whereas HGPRT producing cells can use the salvage pathway to survive. By culturing the fusion products in HAT-medium, possibly only the hybridoma cells survive since they exhibit both characteristics required to survive: the HGPRT production derived from the $B$ lymphocytes and the immortality derived from the myeloma cells [Goding (1996), Harlow and Lane (1988), Peters and Baumgarten (1992)].

\subsubsection{Peptide selection and coupling}

The peptides were derived from specific regions of different serotonin receptor isoform sequences. The amino acid sequences of mouse, rat and man of each receptor were aligned. The alignment and the calculation of the antigenic indices [Kyte and Doolittle (1982)] of the receptor sequences were performed using GCG $^{\circledR}$ Wisconsin Package ${ }^{\text {TM }}$ programmes. Furthermore, the specificity of the selected peptide sequences were tested using the GCG programme BLAST. The lower limit of peptide sequences for coupling should be approximately 10 residues [Harlow and Lane (1988)].

The peptides were coupled to both BSA and KLH with the hetero-bifunctional reagent SMCC which links the peptides to the immunogenic carrier proteins through cysteines. For this, an extra cysteine was normally added to either the $\mathrm{N}$ - or $\mathrm{C}$ terminus to allow one-site coupling to the carrier SMCC.

Solutions for the coupling:

$50 \mathrm{mM}$ phosphate buffer ( $\mathrm{pH}$ 7.5): $76.3 \mathrm{~g} \mathrm{Na}_{2} \mathrm{HPO}_{4} * 12 \mathrm{H}_{2} \mathrm{O}$ and $5.1 \mathrm{~g} \mathrm{NaH} \mathrm{NO}_{4}$ monohydrate made up to $5 \mathrm{I}$ with $\mathrm{ddH}_{2} \mathrm{O}$

$50 \mathrm{mM}$ phosphate buffer (pH 6.8): $8.81 \mathrm{~g} \mathrm{Na}_{2} \mathrm{HPO}_{4} * 12 \mathrm{H}_{2} \mathrm{O}$ and $3.46 \mathrm{~g} \mathrm{NaH}_{2} \mathrm{PO}_{4}$ monohydrate made up to 1 I with $\mathrm{ddH}_{2} \mathrm{O}$

$\mathrm{N}$-ethylmaleimide solution: $10 \mathrm{mg} \mathrm{N}$-ethylmaleimide dissolved in $1 \mathrm{ml}$ PBS

SMCC solution: $25 \mathrm{mg}$ SMCC dissolved in $1 \mathrm{ml}$ DMF

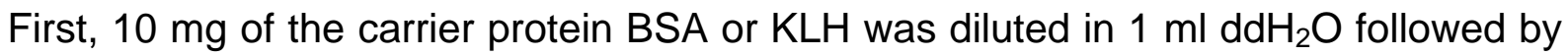
adding $45 \mu \mathrm{N}$-ethylmaleimide solution to inhibit the sulphhydryl groups of the carrier proteins for 30 min at RT. The excessive $\mathrm{N}$-ethylmaleimide was removed by dialysis against four changes of $5 \mathrm{I}$ of $50 \mathrm{mM}$ phosphate buffer $(\mathrm{pH} 7.5)$ overnight at $4^{\circ} \mathrm{C}$. The hetero-bifunctional linker SMCC was coupled afterwards to BSA or KLH. 
Sixty microlitre SMCC was added dropwise $(10 \mu \mathrm{l})$ with stirring to $10 \mathrm{mg}$ blocked BSA or $\mathrm{KLH}$ and incubated for $30 \mathrm{~min}$ at RT on a roller. Ten milligram peptide dissolved in $1 \mathrm{ml}$ of $50 \mathrm{mM}$ phosphate buffer (pH 6.8) and $10 \mathrm{mg}$ of the SMCC-linked carrier proteins were gently mixed and incubated for 4 hours at RT on a roller. Finally, uncoupled peptides were removed via dialysis against four changes of 5 I PBS for 48 hours at $4^{\circ} \mathrm{C}$. The coupling efficiency was tested for the BSA-conjugated peptides by Coomassie blue staining of the BSA-peptide conjugate in comparison with noncoupled BSA which had been separated using SDS-PAGE. The concentration of the BSA- or KLH-conjugated peptides were estimated with the Lowry method.

\subsubsection{Immunisation and serum preparation}

Table 1. Operating schedule of the immunisation

\begin{tabular}{|c|c|c|c|c|}
\hline Species & Day & Antigen $[\mu g]$ & Adjuvant & Procedure \\
\hline \multirow[t]{8}{*}{ WNZ-rabbits } & 0 & & & $1^{\text {st }}$ bleeding \\
\hline & 1 & 500 s.c. & cFA & \\
\hline & 28 & 300 s.c. & iFA & \\
\hline & 56 & 300 s.c. & iFA & \\
\hline & 67 & & & $2^{\text {nd }}$ bleeding \\
\hline & 84 & 300 s.c. & iFA & \\
\hline & 112 & 300 s.c. & iFA & \\
\hline & 119 & & & $3^{\text {rd }}$ bleeding \\
\hline \multirow[t]{5}{*}{ BALB/c-mice } & 0 & & & $1^{\text {st }}$ bleeding \\
\hline & 1 & 200 s.c. & cFA & \\
\hline & 28 & 150 s.c. & TiterMax ${ }^{\mathrm{TM}}$ Gold & \\
\hline & 56 & 150 s.c. & TiterMax $^{\mathrm{TM}}$ Gold & \\
\hline & 67 & & & $2^{\text {nd }}$ bleeding \\
\hline \multirow[t]{12}{*}{ Syrian hamsters } & 0 & & & $1^{\text {st }}$ bleeding \\
\hline & 1 & 200 s.c. & cFA & \\
\hline & 28 & 150 s.c. & TiterMax $^{\mathrm{TM}}$ Gold & \\
\hline & 56 & 150 s.c. & TiterMax $^{\mathrm{TM}}$ Gold & \\
\hline & 67 & & & $2^{\text {nd }}$ bleeding \\
\hline & 84 & 150 s.c. & TiterMax $^{\mathrm{TM}}$ Gold & \\
\hline & 112 & 150 s.c. & TiterMax $^{\mathrm{TM}}$ Gold & \\
\hline & 119 & & & $3^{\text {rd }}$ bleeding \\
\hline & 140 & 150 s.c. & TiterMax $^{\mathrm{TM}}$ Gold & \\
\hline & 168 & 100 i.p. & TiterMax $^{\mathrm{TM}}$ Gold & \\
\hline & 170 & 100 i.p. & TiterMax $^{\mathrm{TM}}$ Gold & \\
\hline & 172 & & & fusion \\
\hline
\end{tabular}

The KLH-conjugated peptides were dissolved in $100 \mu \mathrm{l}$ PBS and thoroughly emulsified with an equal volume of adjuvant which non-specifically enhances the immune response and prevents a fast metabolism of the antigen. 
Prior to immunisation, the water-in-oil emulsion was warmed up to $37^{\circ} \mathrm{C}$ and normally injected subcutaneously in portions into different spots. One week prior to the fusion, the Syrian hamsters were two times injected intraperitoneally with antigen to increase the antibody titre (see table 1). The first blood sample was taken from each animal before any immunisation and served as reference. For the preparation of serum, the blood sample was left at RT for $1 \mathrm{~h}$ to coagulate followed by incubation overnight at $4^{\circ} \mathrm{C}$. The serum was separated from the clot by centrifugation at $3,000 \times \mathrm{xg}$ for $15 \mathrm{~min}$, poured into a clean tube, aliquoted, and finally stored at $-20^{\circ} \mathrm{C}$. Repeated freezing and thawing were avoided.

\subsubsection{Determination of the antibody titre using an ELISA with solid phase- coated antigen}

The principle of the ELISA with solid phase-coated antigen (fig. 5) is based on the adsorbance of the antigen (coating) to the wells of a microtitre plate mainly due to hydrophobic interactions. The specific antibodies of the test serum bind to the coated antigen. Bound antibodies are detected by enzyme-labelled anti-species antibodies (detection antibodies) [Tijssen (1985)].

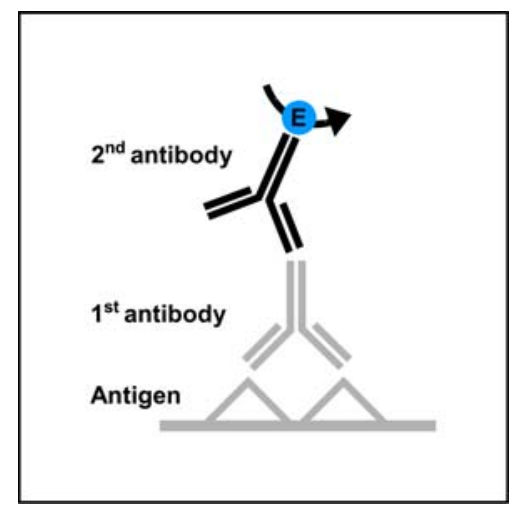

Figure 5. Schematic representation of the ELISA with solid phase-coated antigen: the antigen is adsorbed to the wells of the microtitre plate and detected by the antigen specific antibodies. The HRPconjugated secondary antibodies from a different species are directed against the constant region of the primary antibodies.

\section{Solutions for the ELISA:}

Solution A: $0.2 \mathrm{M} \mathrm{Na}_{2} \mathrm{CO}_{3}(21.2 \mathrm{~g} / \mathrm{l})$

Solution B: $0.2 \mathrm{M} \mathrm{NaHCO}_{3}(8.4 \mathrm{~g} / 500 \mathrm{ml})$

Coating buffer: $85 \mathrm{ml}$ solution $\mathrm{A}$ and $40 \mathrm{ml}$ solution $\mathrm{B}$, made up to $500 \mathrm{ml}$ with $\mathrm{dd}_{2} \mathrm{O}$ Blocking solution: 2\% BSA in PBS

Washing buffer: PBS containing 0.05\% TWEEN 20

ABTS solution: $0.1 \mathrm{M} \mathrm{CH}_{3} \mathrm{COONa} * 3 \mathrm{H}_{2} \mathrm{O}(13.61 \mathrm{~g} / \mathrm{l}), 50 \mathrm{mM} \mathrm{NaH} \mathrm{PO}_{4} * \mathrm{H}_{2} \mathrm{O}(6.9 \mathrm{~g} / \mathrm{l})$ and $2 \mathrm{mM}$ ABTS $(1.1 \mathrm{~g} / \mathrm{l})$, adjusted with $100 \%$ acetic acid to $\mathrm{pH} 4.2$

Developing solution: $9 \mathrm{ml}$ ABTS solution and $40 \mu \mathrm{l} \mathrm{H}_{2} \mathrm{O}_{2}$ 
The antigens (peptides) were diluted in coating buffer $(5 \mu \mathrm{g} / \mathrm{ml})$, and a microtitre plate was then coated with $100 \mu \mathrm{l}$ antigen solution/well overnight at $4^{\circ} \mathrm{C}$. After removing the supernatant, $200 \mu$ l blocking solution was added and applied for 30 min at RT to inhibit non-specific binding sites on the surface of the microtitre plate. The blocking solution was poured out, and $100 \mu \mathrm{l}$ test serum diluted in washing buffer was added to duplicate wells and applied for 2 hours at RT. A limiting two-fold dilution for each serum was pipetted with an initial dilution of $1: 500$. The wells were washed five times afterwards and subsequently filled with $100 \mu \mathrm{l} \mathrm{HRP-conjugated} \mathrm{anti-primary}$ antibody solution (1 : 4,000 dilution)/well for 2 hours at RT. After five more washing steps, $100 \mu$ developing solution/well was added at RT using ABTS as the chromogenic reagent. ABTS functions as electron donor whereby the substrate $\mathrm{H}_{2} \mathrm{O}_{2}$ of the enzyme peroxidase becomes reduced. Since the peroxidase-catalysed conversion follows a short linear kinetic, the colour development was measured at different times $(5,10,15,20,30$, and $40 \mathrm{~min})$ after the beginning of the enzyme reaction. The specific absorbance was measured at $405 \mathrm{~nm}$ (reference wavelength $492 \mathrm{~nm}$ ).

\subsubsection{Purification of polyclonal IgG by affinity chromatography on protein A- sepharose ('low-salt' method)}

Protein $A$ is a normal constituent of the cell wall of the bacterium Staphylococcus aureus and exhibits four potential binding sites for antibodies, whereas two of them can be used at the same time together which allows for forming multimeric complexes. There are extensive hydrophobic interactions with both the second and third constant regions of the $\mathrm{Fc}$ domain (fig. 6). Since the Fc domains of diverse classes and subclasses of antibodies are different, the affinity of protein A for antibodies varies with the class, subclass, and species of the immunoglobulins. Polyclonal antibodies from rabbit with high-affinity binding sites for protein A [Kronvall et al. (1970a) Kronvall et al. (1970b)] can be purified 'conventionally' using the 'low-salt' method [Harlow and Lane (1988)].

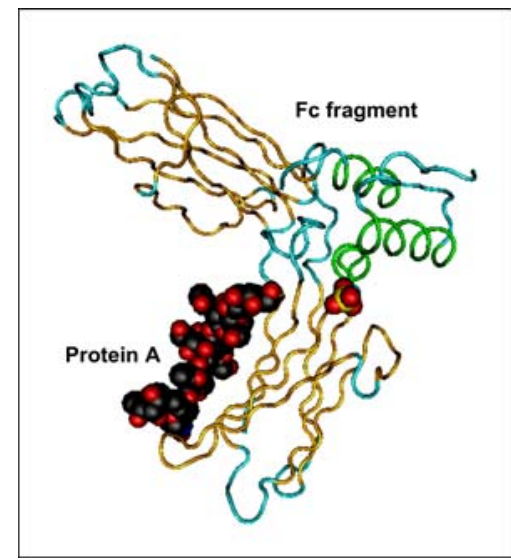

Figure 6. Protein A binding to the Fc fragment of an antibody: representation of the atomic models of the human Fc fragment and its complex with protein A from Staphylococcus aureus based on X-ray diffraction [Deisenhofer (1981)] in which Protein A is represented as a space-filling model. 
Solutions for the 'low-salt' method:

Washing buffer I: $0.1 \mathrm{M}$ Tris/HCl, $\mathrm{pH} 8.0$

Washing buffer II: 10 mM Tris/HCl, $\mathrm{pH} 8.0$

Elution buffer: $0.1 \mathrm{M}$ glycine, $\mathrm{pH} 3.0$

PBS/sodium acide: PBS containing $0.02 \%$ sodium acide

Neutralisation buffer: $1.0 \mathrm{M}$ Tris/HCl, $\mathrm{pH} 8.0$

Regeneration solution: $1 \mathrm{M} \mathrm{LiCl}$

Serum normally contains about $10 \mu \mathrm{g} / \mu \mathrm{l}$ of total IgG. Since the protein A columns bind approximately $10-20 \mu \mathrm{g} \mathrm{lgG} / \mu \mathrm{l}$ wet matrix weight and one molecule protein $A$ binds two antibody molecules, the sera were previously diluted to avoid overloading of the column. The prepacked protein A column was washed with 5 column volumes PBS and subsequently equilibrated with the same volume of washing buffer I. The serum was diluted with an equal volume of $\mathrm{PBS}$, and the $\mathrm{pH}$ value was then adjusted to 8.0 by adding dropwise $1.0 \mathrm{M}$ Tris ( $\mathrm{pH}$ 8.0). After the diluted serum was passed through the column overnight at $4^{\circ} \mathrm{C}$ using a peristaltic pump, the column was washed with 10 column volumes of washing buffer I and subsequently with 10 column volumes of washing buffer II. The antibodies were eluted from the column by gradually adding elution buffer. The eluate was collected in 1.5-ml tubes containing $100 \mu \mathrm{l}$ of $1 \mathrm{M}$ Tris (pH 8.0). Each tube was gently mixed to bring the $\mathrm{pH}$ value back to neutral. The fractions which contain the immunoglobulins were identified by absorbance at $280 \mathrm{~nm}$. An optical density of 1 approximately corresponds to $0.8 \mu \mathrm{g}$ $\mathrm{lgG} / \mu \mathrm{l}$ [Harlow and Lane (1988)]. Samples only containing the elution buffer with 100 $\mu \mathrm{l} 1 \mathrm{M}$ Tris $(\mathrm{pH}$ 8.0) served as reference. Five column volumes of $1 \mathrm{M} \mathrm{LiCl}$ was applied to the column for the regeneration followed by washing with 10 column volumes of PBS/sodium acide. The column was sealed up to eliminate exsiccating and stored at $4^{\circ} \mathrm{C}$. The pooled protein-containing eluates were finally dialysed against two changes of 5 I PBS for 24 hours at $4^{\circ} \mathrm{C}$ and concentrated to at least $1 \mu \mathrm{g}$ $\mathrm{lgG} / \mu \mathrm{l}$ as verified by the Lowry assay. The efficiency of the purification was tested by Coomassie blue staining of the SDS-PAG in which under reducing conditions normally only the heavy ( $55 \mathrm{kDa})$ and light chains $(25 \mathrm{kDa})$ of the purified IgG are visible.

\subsubsection{Production of monospecific polyclonal IgG antibodies by affinity chromatography on CNBr-activated Sepharose ${ }^{\circledR} 4 B$}

The principle of the antigen column chromatography is based on the coupling of purified antigens to a solid matrix for the elimination of immunoglobulins which do not recognise the specific antigen. The antibodies of the polyclonal total IgG fraction (see 2.2.1.5.) differ in their antigen specificity in contrast to homogeneous monoclonal IgG molecules. The immunoaffinity purification isolates the antigen-specific antibodies out of a heterogeneous pool which leads to so-called monospecific polyclonal IgG antibodies. The protein carrier of the peptide column (e.g. BSA) must be distinct from the carrier molecule which was used for the immunisation (e.g. KLH) to avoid the purification of carrier-specific antibodies. 
(A) Coupling of the BSA-conjugated peptides to CNBr-activated Sepharose ${ }^{\circledR} 4 B$

Solutions for the coupling:

Coupling buffer: $0.1 \mathrm{M} \mathrm{NaHCO}_{3}$ and $0.5 \mathrm{M} \mathrm{NaCl}, \mathrm{pH} 8.3$

Blocking buffer: $0.1 \mathrm{M}$ Tris/ $\mathrm{HCl}$ and $0.5 \mathrm{M} \mathrm{NaCl}, \mathrm{pH} 8.3$

Washing buffer: $0.1 \mathrm{M}$ sodium acetate and $0.5 \mathrm{M} \mathrm{NaCl}$ : the $\mathrm{pH}$ value was adjusted with acetic acid to 4.0

PBS/sodium acide: PBS containing $0.02 \%$ sodium acide

First, $2 \mathrm{~g}$ of Sepharose ${ }^{\circledR} 4 \mathrm{~B}$ powder was suspended in $1 \mathrm{mM} \mathrm{HCl}$. The gel swelled immediately and was washed with $400 \mathrm{ml}$ of $1 \mathrm{mM} \mathrm{HCl}$ on a sintered glass filter to eliminate the additives and to preserve the activity of the reactive groups which otherwise easily hydrolyse e. g. at high $\mathrm{pH}$ values. One gram freeze-dried powder resulted in about $3.5 \mathrm{ml}$ final volume of gel. Ten milligram of the BSA-conjugated peptides were dissolved in $10 \mathrm{ml}$ coupling buffer, gently mixed with the gel, and subsequently rotated end-over-end overnight at $4^{\circ} \mathrm{C}$. The excessive ligands were removed afterwards with at least $10 \mathrm{gel}$ volumes of coupling buffer. The remaining active groups of the gel were inhibited with blocking buffer incubating for 2 hours at RT, and the gel was subsequently washed alternately with 5 cycles of washing buffer and coupling buffer. The gel was finally washed with 5 column volumes of PBS/sodium acide.

(B) Purification of antigen specific polyclonal IgG antibodies

Solutions for the purification:

Washing buffer I: $50 \mathrm{mM}$ Tris/ $\mathrm{HCl}$ and $0.4 \mathrm{M} \mathrm{NaCl}, \mathrm{pH} 8.0$

Washing buffer II: $50 \mathrm{mM}$ Tris/ $\mathrm{HCl}$ and $0.4 \mathrm{M} \mathrm{NaCl}, \mathrm{pH} 9.5$

Washing buffer III: $0.1 \mathrm{M}$ sodium acetate, $\mathrm{pH} 5.0$

Elution buffer: $3.5 \mathrm{M} \mathrm{MgCl}_{2}$ dissolved in PBS

The polyclonal total IgG antibody fraction purified on a protein A-sepharose column was adjusted to $0.4 \mathrm{M} \mathrm{NaCl}$ and then diluted 1: 4 with washing buffer I. After the peptide-coupled column had been equilibrated with 10 column volumes of washing buffer I, the diluted antibody solution was applied to the column overnight at $4^{\circ} \mathrm{C}$ using a peristaltic pump. The column was treated with 10 column volumes of each buffer in the following order: washing buffer II, III, and I (high/low pH). The specific polyclonal antibodies were eluted from the column by adding gradually elution buffer. The eluate was collected in 1.5- $\mathrm{ml}$ tubes and measured by absorbance at $280 \mathrm{~nm}$, whereas the pure elution buffer served as reference. Protein-containing samples were combined, dialysed against two changes of 5 I PBS for 24 hours at $4^{\circ} \mathrm{C}$, and finally concentrated to at least $1 \mu \mathrm{g} \mathrm{IgG} / \mu \mathrm{l}$. The column was cleared with 10 column volumes of PBS and stored using PBS/sodium acide. 


\subsubsection{Hybridisation, cloning, and screening of hybridomas}

The hybridisation of two cells is a physical and/or chemical manipulation forcing cells to adhere and fuse with each other. The chemical fusion is normally performed using the detergent polyethylene glycol (PEG) which causes the myeloma- and B lymphocyte cells to adhere that their membranes fuse and multinucleate cells, so-called heterokaryons, are formed [Abbott and Povey (1995), Ringertz and Savage (1976)]. The resultant tetraploid hybridoma cells contain the DNA from both cell types. After the next cell division, the daughter cells possess a more or less equal share of the genetic material. Hybridoma cells are frequently not genetically stable which results from a loss of chromosomes.

\subsection{Hybridisation}

Solutions for the fusion:

HAT-medium: RPMI-1640 containing 10\% FCS, $0.1 \mathrm{mM}$ hypoxanthine, $0.4 \mu \mathrm{M}$ aminopterine and $0.016 \mathrm{mM}$ thymidine which was supplemented with 100 units $/ \mathrm{ml}$ penicillin and $100 \mu \mathrm{g} / \mathrm{ml}$ streptomycin

HT-medium: HAT-medium without aminopterine

Sterile antibiotic solutions: 5,000 units/ml penicillin and $5 \mathrm{mg} / \mathrm{ml}$ streptomycin

50\% PEG 4,000 solution: PEG 4,000 [H(OCH $\left.\mathrm{CH}_{2}\right)_{n} \mathrm{OH}$, $\mathrm{n}$ ranges from 68 to 84] diluted $1: 2$ with PBS, heated up to $50^{\circ} \mathrm{C}$, and autoclaved

Prior to the fusion, peritoneal macrophages as 'feeder cells' were prepared under sterile conditions to support the growth of the hybridoma cells. Feeder cells are cocultured with the hybridoma cells which require growth factors (e.g. IL-6) and trace elements (e.g. selenium). Non-immunised BALB/c mice were sacrificed by $\mathrm{CO}_{2}$ asphyxiation and swabbed with $70 \%$ alcohol. The macrophages were harvested through lavage of the peritoneal cavity with PBS, subsequently washed with HATmedium, and aliquoted into the wells of ten 96-well tissue culture plates. The feeder cell concentration was $5 \times 10^{4}$ macrophages/100 $\mu \mathrm{l} \mathrm{HAT-medium/well.} \mathrm{The} \mathrm{fusion}$ was performed at RT with pre-warmed reagents $\left(37^{\circ} \mathrm{C}\right)$. Syrian hamsters with a high antibody titre (< 1 : 500,000) were sacrificed using $\mathrm{CO}_{2}$ asphyxiation. Blood was withdrawn by puncture of the heart for screening, and the spleen was then removed. Spleen cells were dispersed by injection of $10 \mathrm{ml}$ PBS into the spleen, transferred to a $50-\mathrm{ml}$ tube, and filled up to $40 \mathrm{ml}$ with PBS. After removing a sample for cell count, the cells were centrifuged at $300 \times \mathrm{xg}$ for $5 \mathrm{~min}$. About $2-5 \times 10^{7}$ myeloma cells, being in the exponential period of growth, were washed with RPMI-medium, mixed with $8 x$ $10^{7}-1 \times 10^{8}$ spleen cells (myeloma/spleen cell ratio should be about $10: 1$ ), and centrifuged at $300 \mathrm{xg}$ for $5 \mathrm{~min}$. The supernatant was completely discharged, and the sediment carefully dispersed. Under continuous shaking $750 \mu$ of $50 \%$ PEG 4,000 solution was added dropwise within 1 min followed by $20 \mathrm{ml}$ within the next 4 min. The cell suspension was centrifuged afterwards for $10 \mathrm{~min}$ at $300 \mathrm{xg}$, washed with RPMI-medium, and resuspended in HAT-medium. About $10^{5}$ fused cells/100 $\mu$ HATmedium were plated out in ten 96-well tissue culture plates previously prepared with feeder cells and placed in a humidified incubator at $37^{\circ} \mathrm{C}$ with $5 \% \mathrm{CO}_{2}$ in air. After three days $100 \mu \mathrm{l} /$ well were substituted with fresh HAT-medium. Supernatants were 
tested after 11 days for specific antibody production using an ELISA with solid phasecoated peptide (first screening) after the hybridoma cells had covered at least the half of the well. The selected hybridomas were transferred to 24-well tissue culture plates, cultured in HT-medium, and finally transferred into Petri culture dishes.

\subsubsection{Cloning procedure}

The ELISA-positive hybridoma cells were cloned by limiting dilution to ensure that the antibodies are indeed monoclonal. The fractions with growth should follow the Poisson distribution [Coller and Coller (1983)], if the cells are grown in small numbers $\left[f(0)=e^{-\lambda}, f(0)\right.$ is the fraction of wells with no growth, and $\lambda$ is the average number of clones/well]. To obtain a reasonable probability that wells with growth contain single clones, more than $37 \%$ of wells should have no growth $[\lambda=1, f(0)=0.37]$. This cloning procedure assumes a cloning efficiency of nearly $100 \%$. Since the probability of growth of non-producer variants due to chromosomal loss is relatively high, the positive hybridoma cells were subcloned. After cell counting, a limiting dilution for each clone with an initial dilution of 1,000 cells $/ \mathrm{ml}$ was prepared followed by adding $100 \mu \mathrm{l}$ of each dilution to a 96-well microtitre plate containing macrophages in HTmedium. The hybridoma cells were expanded in a 24-well plate, when they were confluent to approximately $80 \%$. In some cases the subcloning was repeated to confirm monoclonality. In the second screening procedure the supernatants of the hybridoma cells were tested using immunoblotting (see 2.2.2.5.) and immunohisto/cytochemistry (see 2.2.3.) in addition to the ELISA-technique.

\subsubsection{Isotype-characterisation of mAb using sandwich ELISA procedure}

The principle of the sandwich ELISA (fig. 7) is based on the adsorbance of an (capture-) antibody (usually a monoclonal antibody) to the wells of a microtitre plate. The antibodies of the hybridoma supernatants, the isotypes of which are to be determined, bind to the capture antibodies and are detected by enzyme-labelled antibodies (detection antibodies) [Tijssen (1985)].

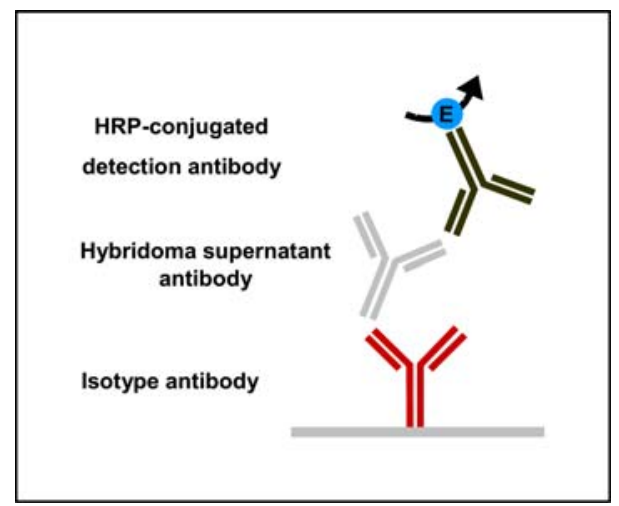

Figure 7. Schematic representation of the sandwich ELISA for the isotype-characterisation: the isotype specific antibodies (capture antibodies) derived from mouse directed against Syrian hamster $\operatorname{lgG}$, IgM, or $\kappa$-light chains are adsorbed to the wells of the microtitre plate (coating) to capture the isotype specific antibodies of the hybridoma supernatants from Syrian hamster. The HRP-conjugated goat anti-Syrian hamster IgG antibodies (detection antibodies) are directed against the antibodies from Syrian hamster. 
Solutions for the sandwich ELISA: see 2.2.1.4.

The anti-isotype capture-antibodies were diluted in coating buffer $(10 \mu \mathrm{g} / \mathrm{ml})$. The microtitre plate was coated with $100 \mu \mathrm{l}$ antibody solution/well overnight at $4^{\circ} \mathrm{C}$. The plate was then washed five times with $300 \mu$ l washing buffer/well. $200 \mu$ l blocking solution (2\% BSA dissolved in PBS) was added and applied for $30 \mathrm{~min}$ at RT to inhibit the non-specific binding sites. The blocking was followed by adding $100 \mu \mathrm{l}$ undiluted supernatant of the subcloned hybridoma cells to duplicate wells for 2 hours at RT. The plate was washed again five times with $300 \mu \mathrm{l}$ washing buffer/well and subsequently filled with $100 \mu$ HRP-conjugated antibody solution (1:4,000 dilution)/well for 2 hours at RT. Five additional washing steps were followed by adding $100 \mu \mathrm{l}$ of developing solution/well at RT in the dark. The specific absorbance was measured at $405 \mathrm{~nm}$ (reference wavelength $492 \mathrm{~nm}$ ). Wells without hybridoma supernatant served as negative controls.

\subsubsection{Purification of monoclonal IgG by affinity chromatography on protein A-sepharose ('high-salt' method)}

Syrian hamster IgG in comparison with rabbit IgG molecules have a relative low affinity for protein A [Harlow and Lane (1988)]. The binding of IgG to protein A can be strengthened by alkaline $\mathrm{pH}$ value [Ey et al. (1978)] and at high-salt concentrations [Malm (1987)].

Solutions for the 'high-salt' method:

Washing buffer I: 50 mM Tris/HCl, $3 \mathrm{M} \mathrm{NaCl}, \mathrm{pH} 8.9$

Washing buffer II: $10 \mathrm{mM}$ Tris/HCl, $3 \mathrm{M} \mathrm{NaCl}, \mathrm{pH} 8.9$

Elution buffer: $0.1 \mathrm{M}$ glycine, $\mathrm{pH} 3.0$

PBS/sodium acide: PBS containing $0.02 \%$ sodium acide

Neutralisation buffer: $1.0 \mathrm{M}$ Tris/HCl, $\mathrm{pH} 8.0$

Regeneration solution: $1 \mathrm{M} \mathrm{LiCl}$

The filtered hybridoma supernatant was initially diluted with an equal volume of PBS. The $\mathrm{NaCl}$ concentration was adjusted to $3.3 \mathrm{M}$ (physiological $\mathrm{NaCl}$ concentration of hybridoma supernatant $0.12 \mathrm{M}$ ), and the $\mathrm{pH}$ value was adjusted to 8.9 by gradually adding solid Tris. After the column was equilibrated with 5 column volumes of washing buffer I, the diluted hybridoma supernatant was passed through the column overnight at $4^{\circ} \mathrm{C}$ in a circulating manner using a peristaltic pump. The protein $\mathrm{A}$ column was washed with 10 column volumes of washing buffer I followed by washing with 10 column volumes of washing buffer II. The antibodies were eluted from the column with elution buffer. The eluate was collected in 1.5-ml tubes containing $100 \mu \mathrm{l}$ of $1 \mathrm{M}$ Tris ( $\mathrm{pH}$ 8.0). Each tube was gently mixed to adjust the $\mathrm{pH}$ value of the eluate back to neutral. The fractions which contained the immunoglobulins were identified by measuring the absorbance at $280 \mathrm{~nm}$. Samples containing only the elution buffer served as reference. Five column volumes of $1 \mathrm{M} \mathrm{LiCl}$ was applied to the column for the regeneration followed by washing with 10 column volumes of PBS/sodium acide 
also serving as storage buffer for the matrix. The column was sealed up to eliminate exsiccating and stored at $4^{\circ} \mathrm{C}$. The combined eluates were finally dialysed against two changes of 5 I PBS for 24 hours at $4^{\circ} \mathrm{C}$ and concentrated using Centriprep YM10. The antibody concentration was determined by the Lowry assay and should amount to at least $1 \mu \mathrm{g} \mathrm{IgG/ \mu l}$. The efficiency of purification was tested using Coomassie blue staining of the SDS-PAG (see 2.2.2.4.) containing the separated IgG.

\subsubsection{Protein chemistry}

\subsubsection{Solubilisation of proteins with Triton X-100}

The non-ionic detergent Triton $\mathrm{X}-100$ is suitable especially for the quantitative solubilisation of membrane proteins by forming small micelles. The structure of the micelles depends on the $\mathrm{pH}$ value, temperature, pressure, and structure of the detergent monomer [Gennis (1989), Neugebauer (1990), Scopes (1982)].

Solutions for the solubilisation:

PBS (1x): $2.33 \mathrm{~g} \mathrm{Na}_{2} \mathrm{HPO}_{4} * 12 \mathrm{H}_{2} \mathrm{O}, 7.2 \mathrm{~g} \mathrm{NaCl}$, and $0.35 \mathrm{~g} \mathrm{NaH}_{2} \mathrm{PO}_{4} * \mathrm{H}_{2} \mathrm{O}$ : the $\mathrm{pH}$ value was adjusted to $7.2-7.4$ with $\mathrm{NaOH}$ and then made up to 1 I with $\mathrm{dd} \mathrm{H}_{2} \mathrm{O}$

Triton X-100 lysis buffer (2x): $50 \mathrm{mM}$ Tris/HCl (pH 8.0), $2 \mathrm{mM}$ EDTA, $2 \mathrm{M} \mathrm{NaCl}$, and $3.6 \%$ Triton $\mathrm{X}-100$

Tissues were previously homogenised before diluted with PBS. An equal volume of Triton X-100 lysis buffer (3.6\%) was added to the diluted cells or tissues that the concentration for the lysis was $1.8 \%$. The lysis was performed on ice for 30 min with occasional vortexing. After a high-speed centrifugation $(100,000 \times \mathrm{xg})$ for $1 \mathrm{~h}$ at $4^{\circ} \mathrm{C}$, the supernatant which contains the initially membrane-bound proteins was quantified for its protein content, treated with protease inhibitor cocktail, aliquoted, and frozen at $-20^{\circ} \mathrm{C}$. The protein concentration was measured with the Lowry assay after the removal of the detergent using TCA precipitation [Bensadoun and Weinstein (1976), Peterson (1977)] and subsequent two-fold washing with acetone.

\subsubsection{Estimating total protein concentration according to Lowry}

The protein estimation with Folin-Ciocalteu's phenol reagent is a modification of the biuret method. Under alkaline conditions copper forms a complex with proteins. The copper-protein complex reduces the phosphomolybdic-phosphotungstic reagent (Folin-Ciocalteu's phenol reagent) by the tyrosine and tryptophan present in the treated protein which leads finally to intensive blue staining [Lowry et al. (1951)]. This method is ten to twenty times as sensitive as measurement of the ultraviolet light absorbance at $280 \mathrm{~nm}$ and 100 times as sensitive as the biuret reaction [Layne (1990)]. 
First, a BSA standard curve with samples of known protein concentrations was prepared. The concentration of the BSA standard solution was $0.1 \mathrm{mg} / \mathrm{ml}$. Duplicate samples containing $1,2,5,7,10,15,20,25,30,40$, and $50 \mu \mathrm{g}$ were made up to 500 $\mu \mathrm{l}$ with PBS. Five hundred microlitre of $40 \%$ TCA was added that the final precipitation concentration amounted to $20 \%$. The samples were stored for $30 \mathrm{~min}$ at $4^{\circ} \mathrm{C}$ on ice followed by maximal centrifugation $(16,000 \mathrm{rpm})$ for $30 \mathrm{~min}$. Subsequently, the protein pellets were washed twice with $1 \mathrm{ml}$ deep-frozen acetone $\left(-20^{\circ} \mathrm{C}\right)$, centrifuged after each wash for $10 \mathrm{~min}$ at $16,000 \mathrm{rpm}$, and finally dried at $60^{\circ} \mathrm{C}$.

\section{Solutions for the Lowry assay:}

Solution $\mathrm{A}: 2 \% \mathrm{Na}_{2} \mathrm{CO}_{3}$ diluted in $0.1 \mathrm{~N} \mathrm{NaOH}$

Solution B: $1 \% \mathrm{CuSO}_{4}$ * $5 \mathrm{H}_{2} \mathrm{O}$ and $2 \%$ potassium sodium tartrate

Solution C: $50 \mathrm{ml}$ solution $\mathrm{A}$ and $1 \mathrm{ml}$ solution $\mathrm{B}$

Solution D: Folin-Ciocalteu's phenol reagent diluted $1: 2$ in ddH2O

The dried BSA pellet was resuspended in $750 \mu \mathrm{l}$ solution $\mathrm{C}$ and incubated for $30 \mathrm{~min}$ at RT. After $75 \mu \mathrm{l}$ solution D had been added and incubated for $30 \mathrm{~min}$ at RT in the dark, the resulting blue staining was measured by absorbance at $578 \mathrm{~nm}$. The extinctions were plotted against the known BSA contents and tested with linear regression. Samples without protein served as reference. The protein concentrations of unknown samples could now be estimated using the prepared BSA standard curve.

\subsubsection{Discontinuous SDS-PAGE}

One-dimensional gel electrophoresis according to Laemmli [Laemmli (1970), Laemmli and Favre (1973)] under denaturing conditions separates proteins based on their molecular sizes as they move through a polyacrylamide gel matrix towards the anode. The attachment of the ionic detergent SDS to proteins mediates both the disruption of the three-dimensional structure of the proteins by breaking non-covalent bonds and the loading of proteins with negative charges which enables the proteins to move in the electrical field. Existing disulfide bonds are reduced with 2-mercaptoethanol or dithiothreitol. The relative mobility of a given protein is linearly dependent on the logarithm of its relative molecular mass [Weber and Osborne (1969)]. The relative molecular masses of unknown proteins are estimated with standard proteins with a known relative molecular weight (molecular weight markers). Polyacrylamide gels are formed by copolymerisation of acrylamide monomers and a cross-linking comonomer, $\mathrm{N}, \mathrm{N}^{\prime}$-methylenebisacrylamide. The polymerisation is catalysed by a free radical-driven system composed of the initiator APS and the accelerator TEMED. The proteins are concentrated in the stacking gel due to differences of the $\mathrm{pH}$ value, and the lower acrylamide concentration, and separated in the resolving gel. Protein samples with low concentrations were precipitated with TCA as described above (2.1.1.). The protein pellet was resuspended in SDS sample buffer, boiled for 10 min at $100^{\circ} \mathrm{C}$, and shortly centrifuged. 
Solutions for the SDS-PAGE:

Acrylamide solution 30\% (30T/3C): $29.1 \mathrm{~g}$ acrylamide and $0.9 \mathrm{~g}$ bisacrylamide

Stacking gel buffer (4x): $0.5 \mathrm{M}$ Tris/ $\mathrm{HCl}(\mathrm{pH} 6.8)$ and $0.4 \%$ SDS

Separating gel buffer (4x): $1.5 \mathrm{M} \mathrm{Tris/HCl}(\mathrm{pH} 8.8)$ and $0.4 \%$ SDS

SDS sample buffer (Laemmli buffer): $20 \mathrm{mM}$ Tris/HCl (pH 8.8), $2 \mathrm{mM}$ EDTA, 2\% SDS, $10 \%$ 2-mercaptoethanol, 10\% glycerine, and $0.3 \%$ bromophenol blue

Running buffer (10x): $30.3 \mathrm{~g}$ Tris and $144.1 \mathrm{~g}$ glycine, made up to $1 \mathrm{I}$ with $\mathrm{dd}_{2} \mathrm{O}$

After assembling the glass-plate sandwich of the electrophoresis apparatus, the stacking and separating gel solutions were prepared (see table 2).

Table 2. Formulations of stacking and separating gels

\begin{tabular}{c|c|c|c|c}
\hline Acrylamide conc. & $\mathbf{1 0 \%}$ & $\mathbf{1 2 \%}$ & $\mathbf{1 5 \%}$ & $\mathbf{4 \%}$ \\
\hline Stacking gel buffer & & & & $0.63 \mathrm{ml}$ \\
\hline Separating gel buffer & $2 \mathrm{ml}$ & $2 \mathrm{ml}$ & $2 \mathrm{ml}$ & \\
\hline $\mathrm{ddH}_{2} \mathrm{O}$ & $3.3 \mathrm{ml}$ & $2.76 \mathrm{ml}$ & $1.95 \mathrm{ml}$ & $1.55 \mathrm{ml}$ \\
\hline Acrylamide solution & $2.7 \mathrm{ml}$ & $3.24 \mathrm{ml}$ & $4.05 \mathrm{ml}$ & $0.33 \mathrm{ml}$ \\
\hline APS & $80 \mu \mathrm{l}$ & $80 \mu \mathrm{l}$ & $80 \mu \mathrm{l}$ & $25 \mu \mathrm{l}$ \\
\hline TEMED & $8 \mu \mathrm{l}$ & $8 \mu \mathrm{l}$ & $8 \mu \mathrm{l}$ & $2.5 \mu \mathrm{l}$ \\
\hline Volume/gel & $8 \mathrm{ml}$ & $8 \mathrm{ml}$ & $8 \mathrm{ml}$ & $2.5 \mathrm{ml}$ \\
\hline
\end{tabular}

When the gel was polymerised the samples were carefully applied as a thin layer at the bottom of the slots. The power supply was connected to the cell, and the gel was run at $20 \mathrm{~mA} / \mathrm{gel}$ for about 2 - 3 hours.

\subsubsection{Coomassie blue staining}

The location of protein bands in a gel can be determined by Coomassie blue staining [Burnette (1981)]. The detection of protein bands depends on non-specific binding of the dye to proteins. The detection limit is 0.3 to $1 \mu \mathrm{g} /$ protein band [Beisiegel (1986)].

Solutions for Coomassie blue staining:

Coomassie blue staining solution: $0.2 \%$ Coomassie brilliant blue R250 dissolved in $30 \%$ ethanol and $10 \%$ glacial acetic acid

Coomassie blue destaining solution: $30 \%$ ethanol and $10 \%$ glacial acetic acid

The SDS-PAG was placed in a plastic container and incubated with 5 gel volumes of staining solution for 2 hours at RT on a rocking shaker. After destaining until blue bands and a clear background were obtained, the SDS-PAG was dried in a gel dryer for 2 hours and photographed afterwards. 


\subsubsection{Immunoblotting/-detection}

The separated proteins of the SDS-PAG can be transferred onto nitrocellulose membranes [protein binding capacity is about $100 \mu \mathrm{g} / \mathrm{cm}^{2}$, Harlow and Lane (1989)] by electroblotting. The transferred proteins are adsorbed to the nitrocellulose membrane, on the surface of which they are accessible to detection with specific poly- or monoclonal antibodies [Beisiegel (1986), Gershoni and Palade (1983)]. The semidry blotting method was performed according to Kyhse-Andersen (1984).

\section{Solutions for immunoblotting/-detection:}

Transfer buffer: $48 \mathrm{mM}$ Tris, $39 \mathrm{mM}$ glycerine, 0.0375\% SDS, and 20\% methanol

Ponceau S stock solution: 2\% Ponceau S and 30\% trichloroacetic acid, made up to $100 \mathrm{ml}$ with $\mathrm{dd}_{2} \mathrm{O}$ : the stock solution was diluted $1: 30$ in TBS for use

TBS (10x): $100 \mathrm{mM}$ Tris and $1.5 \mathrm{M} \mathrm{NaCl}$, adjusted with $\mathrm{HCl}$ to $\mathrm{pH} 7.6$

Washing buffer: TBS containing 0.05\% TWEEN 20

Blocking solution: 2\% BSA dissolved in PBS

Antibody solution: Primary or secondary antibodies were diluted in washing buffer

Developing solution: $20 \mathrm{mg}$ DAB dissolved in $50 \mathrm{ml}$ washing buffer

The gel sandwich was disassembled and the stacking gel removed. After equilibration of transfer membrane and Whatman filter papers in transfer buffer, the transfer stack was assembled on top of the anode in the following order: 4 sheets of Whatman filter paper, equilibrated transfer membrane, gel, and finally 4 sheets of Whatman filter paper. Bubbles were removed and the cathode was placed on the transfer stack. A constant current of $150 \mathrm{~mA}$ was applied for 1 - 2 hours to transfer the proteins. The blotted membrane was removed, and the efficiency of the transfer of proteins was tested with both the removable Ponceau staining [Salinovich and Montelaro (1986)] of the membrane and Coomassie blue staining of the remaining protein in the gel. The Ponceau solution was completely removed from the membrane, and non-specific binding sites were inhibited afterwards by incubation of the membrane in blocking solution for $1 \mathrm{~h}$ at RT. The primary antibody solution was applied to the membrane in appropriate concentrations $(1 \mu \mathrm{g} / \mathrm{ml}-5 \mu \mathrm{g} / \mathrm{ml})$ depending on the antibody for 2 hours at RT or alternatively overnight at $4^{\circ} \mathrm{C}$. After three washing steps for $5 \mathrm{~min}$ each, the membrane was incubated with HRPconjugated antibody solution (1:3,000 to $1: 5,000)$ for 2 hours at RT (fig. 8). After extensive washing steps, the membrane was incubated in the developing solution. The visualisation of the antigen-antibody reaction was initiated by adding $50 \mu \mathrm{l}$ of $35 \% \mathrm{H}_{2} \mathrm{O}_{2}$. The chromogenic substrate DAB precipitates on the membrane which results in brown colour of specific bands. The development was terminated with further washing steps using TBS/TWEEN. Finally, the membrane was air dried and photo-graphed. 


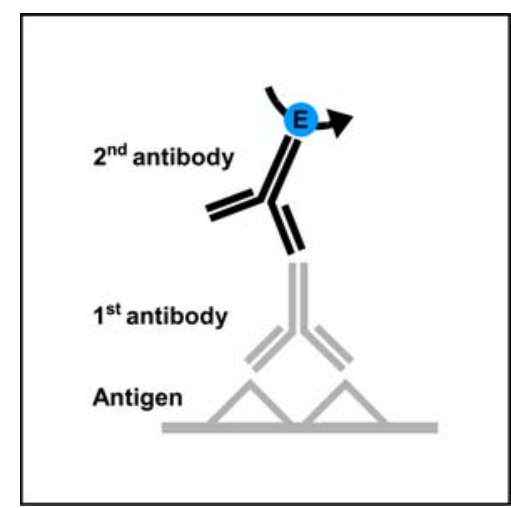

Figure 8. Schematic representation of the immunoblot procedure: the antigen which is adsorbed to the membrane is detected by the specific primary antibodies derived from species A. The HRP-conjugated secondary antibodies developed from another species are directed against the constant region of the antibodies from species $A$.

\subsubsection{Immunohisto- /cytochemistry}

\subsubsection{Preparation of brain tissue for immunohistochemistry}

Neo- and postnatal Sprague-Dawley rats (P 0 - P 30) were deeply anaesthetised with ether until they were unresponsive to painful stimuli. A thoracotomy was performed, and animals were transcardially perfused with $50 \mathrm{ml} 0.9 \%$ sodium chloride followed by $200 \mathrm{ml} 4 \%$ phosphate-buffered formaldehyde $\left(10 \mathrm{ml} \mathrm{x} \mathrm{min}^{-1}\right)$. The brainstem and the spinal cord were removed and post-fixed for 4 hours with the same fixative at $4^{\circ} \mathrm{C}$. The tissue was cryoprotected in $10 \%$ sucrose for 2 hours followed by $30 \%$ sucrose in $0.1 \mathrm{M}$ phosphate buffer overnight at $4^{\circ} \mathrm{C}$ and frozen at $-25^{\circ} \mathrm{C}$ afterwards. Embryos (E 14 - E 20) were fixed with 4\% phosphate-buffered formaldehyde overnight at $4^{\circ} \mathrm{C}$ by immersion and followed up as described above. Series of $20-$ and $40-\mu \mathrm{m}$-thick transversal and sagittal slices ranged from the lumbar spinal cord to the pons were cut using a cryoslicer. Before any immunohistochemical treatment, free-floating slices were rinsed three times in PBS for 15 min each.

\subsubsection{Immunofluorescence}

The slices were permeabilised with $0.2 \%$ Triton $\mathrm{X}-100$ for $30 \mathrm{~min}$ at RT and then washed two times with PBS. The non-specific binding sites were blocked with PBS containing 5\% BSA for $1 \mathrm{~h}$ at RT. After washing with PBS for three times of $10 \mathrm{~min}$ each, the slices were incubated for 6 hours at RT or, alternatively, 24 - 72 hours at $4^{\circ} \mathrm{C}$ in primary antibody solution (2\% BSA/PBS, antibody dilution ranged from $1: 25$ to $1: 500$ ) followed by three washing steps for 15 min each. The slices were then incubated for $4 \mathrm{~h}$ at RT in the dark with species-specific fluorochrome-conjugated secondary antibodies (2\% BSA/PBS, antibody dilution ranged from 1: 100 to 1 : 500). Extensive washing (three times, 30 min each) was followed upon the incubation and finally, the slices were mounted in sequential order onto slides and coverslipped with fluorescent mounting medium. Immunofluorescence analysis was performed using a confocal laser-scanning microscope (Meta-LSM 510). 


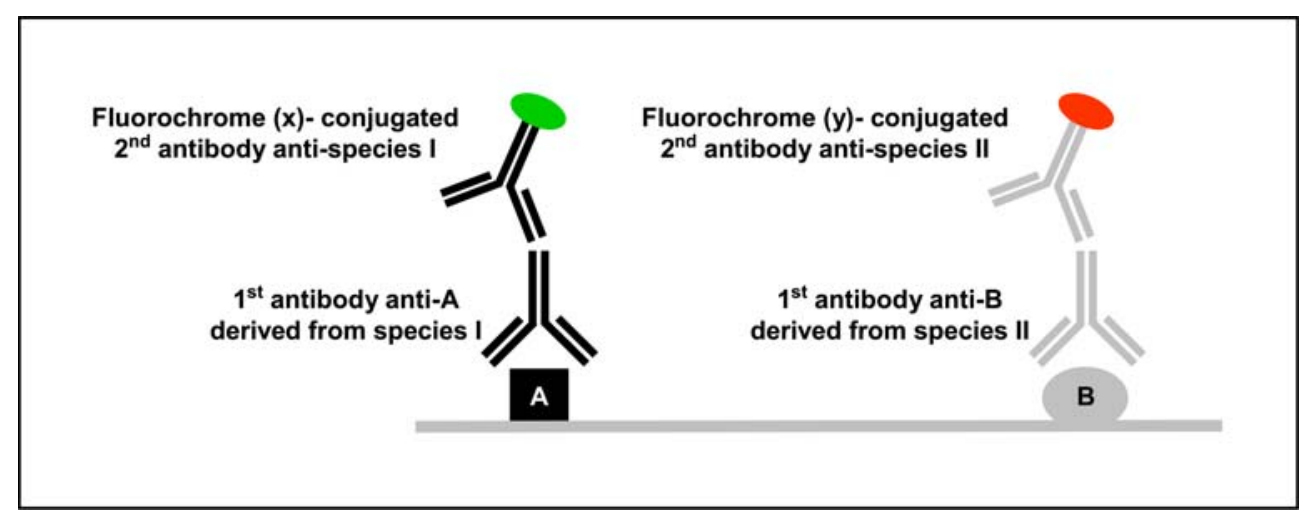

Figure 9. Schematic representation of double labelling procedure in immunohisto- /cytochemistry: the antigen $A$ is detected by the specific primary antibodies derived from species I and antigen $B$ by the specific antibodies derived from species II. The fluorochrome (X)-conjugated secondary antibodies are directed against the constant regions of the primary antibodies from species I, whereas the fluorochrome $(Y)$-conjugated antibodies only recognise the constant regions of primary antibodies from species II. Primary and secondary antibodies must be developed from different species.

\subsubsection{Immunocytochemistry}

Living cells were applied to slide wells. After removing the medium, the cells were cautiously three times washed with PBS for 5 min each at RT and fixed with 4\% paraformaldehyde for $10 \mathrm{~min}$. The cells were permeabilised with $0.2 \%$ Triton X-100 for $10 \mathrm{~min}$, washed three times with PBS, treated with 5\% BSA/PBS for $30 \mathrm{~min}$, and then incubated with the primary antibody solution (2\% BSA/PBS, antibody dilution ranged from $1: 50$ to $1: 500$ ) for 2 hours at RT. Afterwards, the cells were washed for three times with PBS for 5 min each and incubated with the secondary antibody solution (2\% BSA/PBS, antibody dilution ranged from $1: 100$ to $1: 500$ ) for $1 \mathrm{~h}$ at RT in the dark which was rinsed out with three changes of PBS. Finally, the cells were coverslipped with fluorescent mounting medium and subsequently analysed with the confocal laser-scanning microscope. Data acquisition and analysis of confocal images were done using the Meta-LSM 510 software provided by Zeiss.

\subsubsection{Confocal laser-scanning microscopy (CLSM)}

The confocal laser-scanning microscopy (CLSM) makes it possible to observe thin optical sections in thick, intact specimens (fig. 10). Fluorescent specimens are excited with laser light and the emitted fluorescence is detected confocally which prevents the detection of out-of-focus light. The combination of the optical arrangement of a confocal microscope invented by Marvin Minsky in 1953 [Minsky (1988)] and the laser technology allows for detection of fluorescence light which is emitted by the specimen in the focal plane. CLSM uses a tiny laser spot focused in a defined image plane to excite fluorescence. This spot is scanned point-by-point in lines across the field of view to produce a two-dimensional image ( $x-y$ axis). A three-dimensional one can be assembled from a stack of two-dimensional images by moving the objective in z-direction. The CLSM does not record the wavelength of the fluorescence. The emission wavelengths of different fluorochromes can indirectly be analysed with multichannel detection. By use of several channels provided with an emission filter and a photomultiplier with high sensitivity, different fluorochromes can be separated from each other which allows for multiple labelling. 


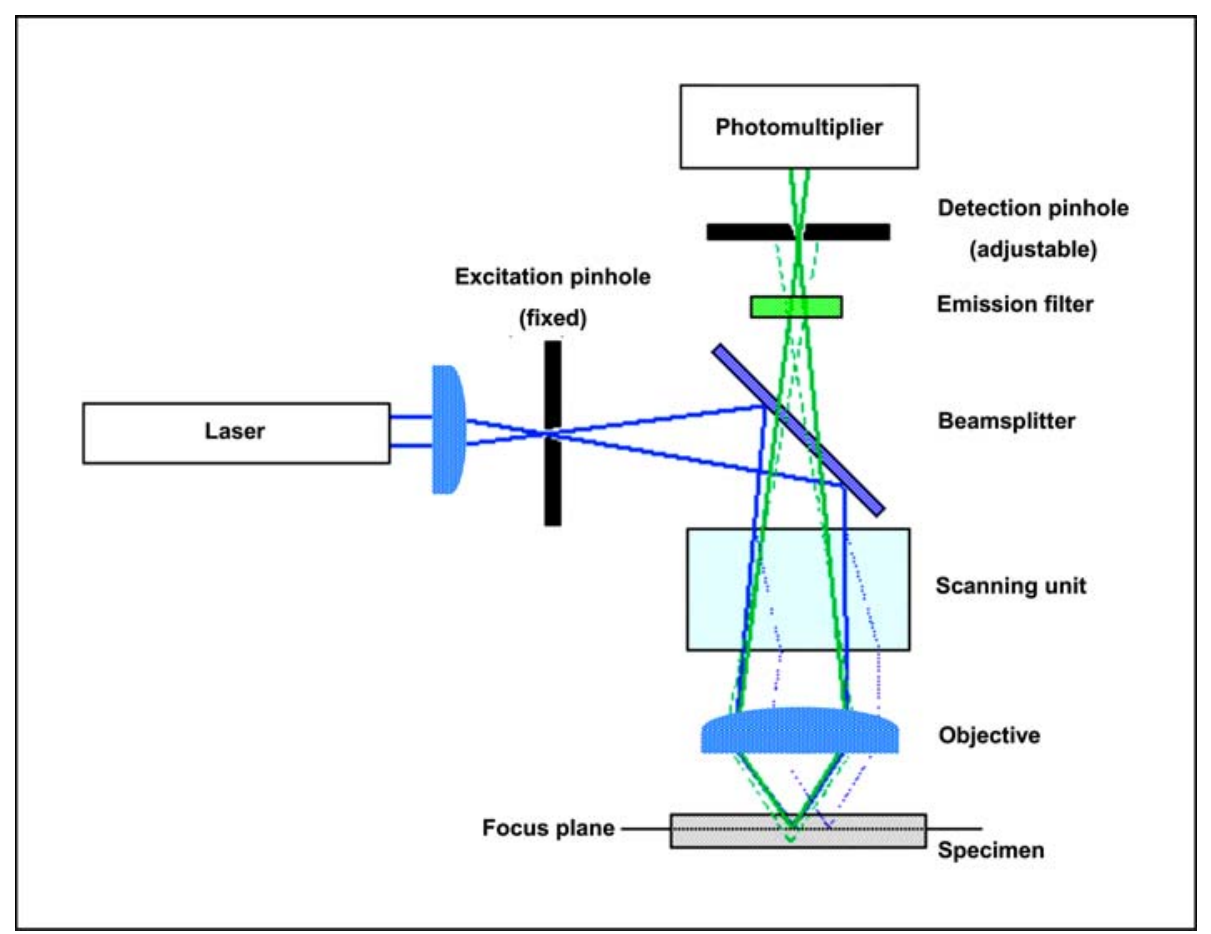

Figure 10. Principal function of a confocal laser-scanning microscope

\subsubsection{Peroxidase anti-peroxidase (PAP) and (strept)avidin-biotin-complex $(A B C)$ staining}

The staining sequence of the PAP method consists of the use of an unconjugated primary antibody, a secondary antibody, the soluble enzyme-anti-enzyme complex (PAP) and the substrate solution. The primary antibody and the antibody of the enzyme immune complex must be made in the same species. The secondary antibody must be directed against immunoglobulins of the species producing both the primary antibody and the enzyme immune complex. The secondary antibody is normally added in excess so that one of its two Fab sites binds to the primary antibody leaving the other site for binding the antibody of the enzyme immune complex (fig. 11A).

The basic sequence of the $A B C$ method (fig. 11B) consists of a primary antibody, a biotinylated secondary antibody, followed by the preformed (strept)avidin-biotinenzyme complex concluding with the substrate solution. The enzyme is labelled with horseradish peroxidase (HRP). This immunochemical staining method based on the high affinity $\left(\mathrm{K}=10^{-15} \mathrm{M}\right)$ that (strept)avidin derived from Streptomyces avidinii and avidin derived from chicken egg have for biotin. 


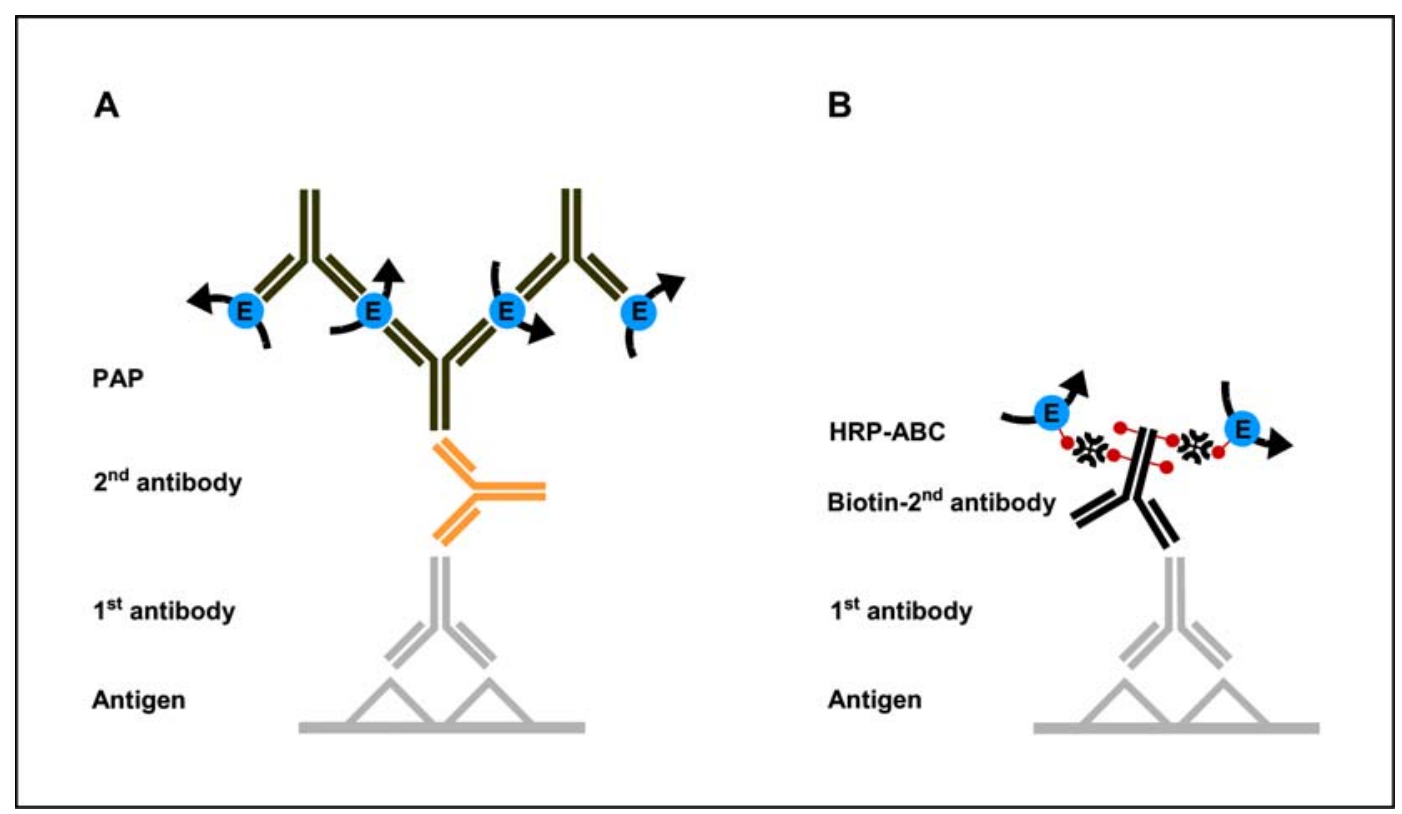

Figure 11. PAP and ABC staining: (A) PAP staining: the antigen is detected by specific primary antibodies which are derived from the same species $A$ as the peroxidase anti-peroxidase complex. The secondary antibodies developed from species $\mathrm{B}$ are directed against the constant region of the primary antibodies and the peroxidase anti-peroxidase complex. (B) ABC staining: the biotin-conjugated secondary antibodies derived from species $B$ are directed against the constant region of the primary antibodies developed from species $\mathrm{A}$. The horseradish-conjugated avidin-biotin complex reacts with the biotin-labelled secondary antibodies. The precipitating chromogen DAB is applied to visualise the antigen-antibody reaction.

Solutions for the PAP- and ABC-staining:

Antibody solution: $1^{\text {st }}$ or $2^{\text {nd }}$ antibodies were diluted in $2 \%$ BSA/PBS

Blocking solution: 5\% BSA/PBS

Permeabilisation solution: $0.2 \%$ Triton $\mathrm{X}-100$

DAB solution: $120 \mu \mathrm{LAB}$ (75 mg DAB dissolved in $1.5 \mathrm{ml} 0.1 \mathrm{M}$ phosphate buffer), $240 \mu \mathrm{l} 1.25 \% \mathrm{CoCl}_{2}$, and $240 \mu \mathrm{l} 5 \% \mathrm{Ni}\left(\mathrm{NH}_{4}\right)_{2} \mathrm{SO}_{4}$ diluted in $29.4 \mathrm{ml}$ PBS

PAP and $A B C$ staining (fig. 11): The endogenous peroxidase activity of the slices was blocked using methanol/35\% $\mathrm{H}_{2} \mathrm{O}_{2}$ (1: 100 dilution) for 45 min at $\mathrm{RT}$ in the dark. After washing the slices for three times (10 min each), they were permeabilised with $0.2 \%$ Triton X-100 for 30 min and directly transferred into PBS containing 5\% BSA for $1 \mathrm{~h}$ at RT to block non-specific binding sites. The slices were incubated in primary antibody solution (antibody dilution ranged from $1: 500$ to $1: 5,000$ ) overnight at $4^{\circ} \mathrm{C}$ and subsequently washed three times for $10 \mathrm{~min}$ each. The secondary antibodies (diluted $1: 100$ ) were applied for $1 \mathrm{~h}$ at RT and rinsed out with PBS three times for 10 min each. After incubation in PAP or HRP-ABC solution $(1: 100)$ for $1 \mathrm{~h}$ at RT, the slices were extensively washed and then pre-incubated with freshly prepared filtered $\mathrm{DAB}$ solution for $10 \mathrm{~min}$ at RT. The enzymatic reaction was started by adding $10 \mu \mathrm{l}$ of $35 \% \mathrm{H}_{2} \mathrm{O}_{2}$ to $30 \mathrm{ml}$ DAB solution. As soon as the appropriate colour occurred, the reaction was immediately stopped with PBS. The DAB-stained slices were washed in PBS, mounted to gelatine coated slides, dehydrogenated $(2 \times 50 \%$ ethanol, $2 \times 80 \%$ ethanol, and $2 \times 99.9 \%$ ethanol, 5 min each), cleared with four changes of xylene, coverslipped with DePeX, and finally analysed with the AxioVision system (Zeiss). 


\subsubsection{Fluorescence-activated cell sorter (FACS), 'flow cytometry}

The FACS analysis is also known as flow cytometry. The main principle (fig. 12) of the FACS is the simultaneous measurement of different physical-chemical cell properties of a cell suspension on single-cell level [Raffael (1988)]. Unlike visual fluorescence microscopy the readout is rapid, objective, and quantitative. A laser light of a single frequency is directed at a hydrodynamically focused stream of fluid. A number of detectors are aimed at the point where the stream passes through the light beam. The forward scatter is in line with the light beam and several side scatters and one or more fluorescent photodetectors are perpendicular to it. Each suspended particle passing through the beam scatters the light, and fluorescent chemicals in the particle may be excited to emit light at a lower frequency than the light source. The photodetectors are activated by scattered and fluorescence light. By analysing fluctuations in brightness at each detector (one for each fluorescent emission peak) it is possible to deduce various physical-chemical properties of each individual particle such as size, shape, internal complexity, granularity, and any cell component or function that can be detected by a fluorescent compound. The FACS can analyse several thousand particles every second in real time and can actively separate out and isolate particles having specified properties. The application of fluorochromeconjugated antibodies directed against specific antigen binding primary antibodies makes it possible to obtain information about the protein expression in or on the target cells. The intensity of the fluorescence can be used to quantitate the amount of antigen being measured by comparing the signal to known standards. The detection limit is as low as 100 fluorescent molecules per cell. The FACS data can be plotted one-dimensionally or two-dimensionally to produce histograms or dot plots. The regions on these plots can be sequentially separated by a series of subset extractions which are termed gates. The plots are normally made on semi-logarithmic scales.

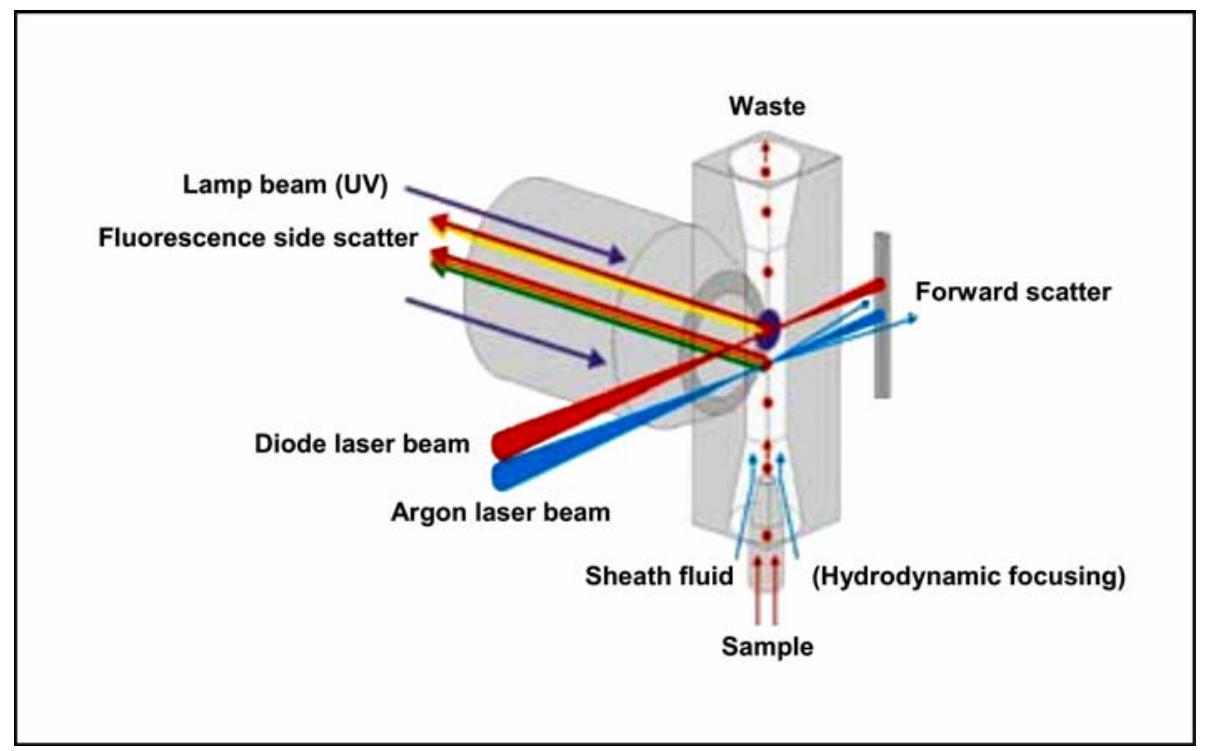

Figure 12. Principal function of the FACS scan: cells are treated with antigen specific primary antibodies which are recognised by fluorochrome-conjugated anti-species antibodies. The labelled cell suspension passes a laser beam in which the scattered and the emitted fluorescence light is detected. 
Solutions for the FACS-analysis:

4\% paraformaldehyde solution: 2 g paraformaldehyde (4\% w/v) dissolved in $25 \mathrm{ml}$ $\mathrm{dd}_{2} \mathrm{O}$ was heated up to $60^{\circ} \mathrm{C} .2 \mathrm{mM} \mathrm{NaOH}$ was added dropwise until the solution appeared clear and then filled up to $50 \mathrm{ml}$ with PBS (2x). The $\mathrm{pH}$ value was adjusted to 7.4 with $1 \mathrm{~N} \mathrm{HCl}$.

FCS was heated up to $56^{\circ} \mathrm{C}$ for $45 \mathrm{~min}$ to inactivate the complement factors before preparing solutions containing FCS.

FACS buffer: $7.5 \mathrm{ml} \mathrm{FCS}$ and $5 \mathrm{ml}$ sodium acide (10\%) made up to $500 \mathrm{ml}$ with PBS saponin/FACS buffer: FACS buffer containing $0.1 \%$ saponin

FACS-fix: $7.5 \mathrm{ml}$ FCS, $5 \mathrm{ml}$ sodium acide and $13.5 \mathrm{ml}$ formaldehyde (37\%) made up to $500 \mathrm{ml}$ with PBS

saponin/PBS solution: $0.1 \mathrm{~g}$ saponin $(0.1 \% \mathrm{w} / \mathrm{v})$ and $1 \mathrm{ml}$ FCS made up to $100 \mathrm{ml}$ with PBS (1x)

Antibody solution: primary or secondary antibodies were diluted in saponin/FACS buffer

For an intracellular staining, the cells were washed initially with PBS, and the number of cells was determined using a Neubauer counting chamber. At least $1 \times 10^{6}$ cells were resuspended in freshly prepared 4\% paraformaldehyde solution for $10 \mathrm{~min}$ on ice to fix the cells, centrifuged for $10 \mathrm{~min}$ at 500xg, washed with $150 \mu \mathrm{l} \mathrm{FACS}$ buffer, centrifuged as above, and subsequently incubated in $150 \mu \mathrm{l}$ saponin/PBS solution for $20 \mathrm{~min}$ on ice to permeabilise the cells. The glycolipid saponin (detergent) interacts with cholesterol and other membrane proteins and, thus, permeabilises the plasma membrane for antibody penetrating. The primary antibody solution was applied for 40 min on ice followed by two washing steps with saponin/FACS buffer. The cells were then resuspended in secondary antibody solution for $40 \mathrm{~min}$ on ice in the dark. Finally, the cells were washed three times with saponin/FACS buffer, centrifuged, resuspended in $200 \mu \mathrm{l}$ FACS-fix, and transferred to FACS tubes. The cells could be stored for several days until their analyses. Extracellular stainings were done without any saponin to test the specificity of antibodies which are directed against intracellular epitopes. Samples without primary antibody served as negative controls. 


\subsubsection{Molecular biology}

\subsubsection{Cell transfection}

Before the transfection of mammalian cells (NBT or RBL) with Lipofectamine ${ }^{T M} 2000$, $0.5-2 \times 10^{5}$ cells in $500 \mu \mathrm{l}$ of growth medium without antibiotics were plated out in 24-well tissue culture plates to a confluence of $90-95 \%$ at the time of transfection. Nought point eight microgram DNA was diluted in $50 \mu \mathrm{l}$ Opti-MEM ${ }^{\circledR}$ and gently mixed. Two microlitre of Lipofectamine was diluted in $50 \mu \mathrm{l}$ Opti-MEM, carefully mixed, and incubated for $5 \mathrm{~min}$ at RT. The diluted Lipofectamine and DNA were combined and left for $30 \mathrm{~min}$ at RT. One hundred microlitre of DNA-Lipofectamine complexes was added to each well containing cells and medium. The plates were cautiously mixed by continuous rocking. The cells were then incubated at $37^{\circ} \mathrm{C}$ in an incubator with $5 \%$ $\mathrm{CO}_{2}$ in air for 3 hours followed by replacing the growth medium. After incubation for 24 - 48 hours, the cells were skimmed off, washed twice with PBS, and finally prepared for immunocytochemistry or immunoblotting.

\subsubsection{Reverse transcriptase-polymerase chain reaction (RT-PCR)}

The transcription of the RNA into the complementary DNA (cDNA) using reverse transcriptase (RT) is a precondition for the indirect amplification of mRNA. The cDNA is afterwards used as a template for a conventional PCR to amplify specifically the target DNA (RT-PCR).

\subsection{Total RNA isolation}

The total RNA was isolated using the GenElute ${ }^{\mathrm{TM}}$ Mammalian Total RNA Kit. Cells or homogenised tissue were lysed in $500 \mu$ l of lysis solution containing $5 \mu \mathrm{l}$ 2-mercaptoethanol. The lysate was transferred to the filtration column and centrifuged at 16,000 rpm (Eppendorf Centrifuge 5415D) for 2 min. An equal volume of $70 \%$ ethanol was added and thoroughly mixed. Seven hundred microlitre of the lysate/ethanol mixture was then applied to the binding column and centrifuged at $16,000 \mathrm{rpm}$ for $15 \mathrm{~s}$. The flowing-through was discarded followed by a wash with $500 \mu \mathrm{l}$ wash solution I. After centrifugation at $16,000 \mathrm{rpm}$ for $15 \mathrm{~s}$, the column was transferred to a new collection tube. Five hundred microlitre wash solution II containing ethanol was applied to the column and centrifuged at $16,000 \mathrm{rpm}$ for 2 min afterwards to remove the ethanol. The column was transferred to a new collection tube, and the RNA was finally eluted with $50 \mu$ l elution solution by centrifugation at $16,000 \mathrm{rpm}$ for $1 \mathrm{~min}$. The concentration and purity of the RNA was determined by spectrophotometric analysis. The RNA was diluted in TE-buffer $(10 \mathrm{mM}$ Tris/ $\mathrm{HCl}$ and $1 \mathrm{mM} E D T A, p H ~ 7.4)$ and measured by absorbance at $260 \mathrm{~nm}$ and $280 \mathrm{~nm}$. Samples without RNA served as reference. An absorbance of 1.0 at $260 \mathrm{~nm}$ corresponds to approximately $40 \mu \mathrm{g} / \mathrm{ml}$ RNA. The ratio of absorbance at $260 \mathrm{~nm}$ to $280 \mathrm{~nm}$ should be between 1.8 to 2.1. The Amplification Grade DNase I was used to eliminate residual genomic DNA from the total RNA preparation. The following components were added to a $0.5-\mathrm{ml}$ tube on ice: $2 \mu \mathrm{g}$ of total RNA, 10x reaction buffer [0.2 M Tris/ $\mathrm{HCl}(\mathrm{pH} 8.4), 0.5 \mathrm{M} \mathrm{KCl}$, and 20 $\mathrm{mM} \mathrm{MgCl}_{2}$ ], and $1 \mu \mathrm{l}$ DNase I which were made up to $10 \mu \mathrm{l}$ with DEPC-treated water. 
After an incubation for 15 min at RT, $1 \mu$ of 25 mM EDTA was added and incubated for $15 \mathrm{~min}$ at $65^{\circ} \mathrm{C}$. Finally, the mixture was placed on ice for $1 \mathrm{~min}$ and collected by brief centrifugation. It could be directly used for reverse transcription.

\subsubsection{First-strand cDNA synthesis}

The isolated RNA was transcribed into the cDNA using the SuperScript ${ }^{\mathrm{TM}}$ FirstStrand Synthesis System. The following RNA/primer mixture for each sample was prepared in sterile $0.5-\mathrm{ml}$ tubes: $2 \mu \mathrm{g}$ total RNA, $1 \mu \mathrm{l}$ random hexamers $(50 \mathrm{ng} / \mu \mathrm{l}), 1$ $\mu \mathrm{l}$ Oligo(dT) 12 - $18(0.5 \mu \mathrm{g} / \mu \mathrm{l})$, and $1 \mu \mathrm{l} 10 \mathrm{mM}$ dNTP mix which were made up to $10 \mu \mathrm{l}$ with DEPC-treated water. The samples were incubated at $65^{\circ} \mathrm{C}$ for 5 min followed by an incubation on ice for at least $1 \mathrm{~min}$. Nine microlitre of the previously prepared reaction mixture [2 $\mu \mathrm{l} \mathrm{RT}$ buffer (10x), $4 \mu \mathrm{l} 25 \mathrm{mM} \mathrm{MgCl}_{2}, 2 \mu \mathrm{l} 0.1 \mathrm{M}$ DTT, and $1 \mu \mathrm{l}$ RNaseOUT Recombinant Ribonuclease inhibitor] was added to the RNA/primer mixture, gently mixed, collected by brief centrifugation, and incubated at $25^{\circ} \mathrm{C}$ for 2 min. One microlitre of SuperScript ${ }^{\mathrm{TM}}$ II RT (50 units) was added, gently mixed, and incubated at $25^{\circ} \mathrm{C}$ for $10 \mathrm{~min}$. The samples were heated to $42^{\circ} \mathrm{C}$ and incubated for 50 min. The reaction was terminated at $70^{\circ} \mathrm{C}$ for $15 \mathrm{~min}$. The samples were stored on ice for 5 min and treated afterwards with RNase $\mathrm{H}$ at $37^{\circ} \mathrm{C}$ for 20 min to remove residual RNA. Finally, the cDNA was stored at $-70^{\circ} \mathrm{C}$. Samples without reverse transcriptase served as negative controls for the following PCR to exclude the amplification of genomic DNA.

\subsection{Primer design}

Specific forward and reverse primer were derived from different exons of the target cDNA to avoid the amplification of genomic DNA and were designed by using the Primer3 programme. The cDNA sequences were obtained from the Ensemble data bank (Sanger Institute). The specificity of the selected primers was tested by sequencing the amplicons for their identification by SeqLab company (Göttingen). All primers, containing a G/C content between $40 \%$ and $60 \%$, were designed for the same melting temperature $\left(T_{m}=55^{\circ} \mathrm{C}\right)$. The primer pairs were tested for both hairpin structures, which are formed by hybridisation of a primer to a complementary portion within the same primer, and for primer-dimer formation.

\subsubsection{Polymerase chain reaction (PCR)}

The polymerase chain reaction (PCR) [Mullis and Faloona (1987), Mullis et al. (1986)] used for gene mapping, cloning, DNA sequencing, and gene detection is composed of cycles of heating and cooling. A PCR cycle begins with the denaturing of the DNA (template) by heating during which the double strands of the DNA molecule break apart into single-stranded DNAs. Primers, short pieces of DNA complementary to a specific sequence, bind to their specific part of every singlestranded DNA during the annealing step at about $55^{\circ} \mathrm{C}$. The temperature is raised again and a specific thermostable enzyme called Taq polymerase derived from the bacterium Thermophilus aquaticus adds complementary dNTPs (5' to $3^{\prime}$ ) from the end of the primer along the rest of the single-stranded DNA templates (extension at about $72^{\circ} \mathrm{C}$ ), whereas the template is read from $3^{\prime}$ to $5^{\prime}$ side. The entire process is repeated a large number of times (cycles) to yield millions of copies of the specific 
DNA region (amplicon). The expected exponential amplification for a given number of cycles ' $n$ ' of the desired defined length product with respect to the original template concentration ' $x$ ' is approximately represented by the formula:

$$
\left[\left(2^{n}-(n+1)\right)-(n+1)\right] x
$$

PCR-reaction using PANScript red DNA polymerase: The PCR reaction mixture for one sample was composed of $1-2 \mu \mathrm{l}$ cDNA, $1 \mu \mathrm{l}$ sense primer, $1 \mu \mathrm{l}$ antisense primer, $1 \mu \mathrm{l}$ dNTPs (100 mM dNTP mix), $1 \mu \mathrm{l}$ DMSO, $5 \mu \mathrm{NH}_{4}$ buffer (10x), $2 \mu \mathrm{l}$ $\mathrm{MgCl}_{2}$ (50 mM solution), and $1 \mu \mathrm{l}$ PANScript red DNA polymerase. The mixture was filled up to $50 \mu \mathrm{l}$ with DEPC-treated water. For several samples normally a 'mastermix ' was prepared to minimise the pipetting errors. The following programme was used for the PCR: $94^{\circ} \mathrm{C}, 4 \mathrm{~min} / 38 \times\left[94^{\circ} \mathrm{C}, 1 \mathrm{~min} / 55^{\circ} \mathrm{C}, 1 \mathrm{~min} / 72^{\circ} \mathrm{C}, 2 \mathrm{~min}\right] / 72^{\circ} \mathrm{C}, 10$ $\min / 4^{\circ} \mathrm{C}$ hold. The 'housekeeping gene' $\beta$-actin was used as an internal standard for all $\mathrm{PCR}$ reactions.

\subsubsection{Single-cell RT-PCR on identified respiratory neurones}

In order to collect the cytosol for the single-cell RT-PCR analysis, superficially located cells were patched under visual control using the IR-microscopy and identified as inspiratory neurones by their ongoing rhythmic activity occurring synchronously with hypoglossal burst discharges (see 2.2.6.1.1.). Subsequently, a constant suction was applied for 1 - $2 \mathrm{~min}$ to harvest the cytoplasm of the identified cells. Reverse transcription (RT) was carried out at $25^{\circ} \mathrm{C}$ for 10 min followed by RT for 50 min at $42^{\circ} \mathrm{C}$ using SuperScript II RT. For all amplification reactions, the primer concentration was $0.2 \mu \mathrm{M}$, and all primers were tested on plasmid as well as on total brain cDNA.

PCR-reaction using AmpliTag Gold polymerase: The cycling conditions for the amplification with the AmpliTag Gold polymerase were a hot start at $95^{\circ} \mathrm{C}$ for $10 \mathrm{~min}$, 40 cycles at $94^{\circ} \mathrm{C}$ for $30 \mathrm{~s}, 53^{\circ} \mathrm{C}\left(5-\mathrm{HT}_{4(\mathrm{a})}\right.$ receptor) or $56^{\circ} \mathrm{C}$ ( $\mu$-opioid and $\mathrm{NK}-1$ receptors) for $30 \mathrm{~s}, 72^{\circ} \mathrm{C}$ for $1 \mathrm{~min}$, and an elongation step at $72^{\circ} \mathrm{C}$ for $10 \mathrm{~min}$.

PCR-reaction using AccuPrime Taq DNA polymerase: In parallel, the PCR was also performed with the AccuPrime Taq DNA polymerase system: $94^{\circ} \mathrm{C}$ for 2 min followed by 39 cycles of denaturation $\left(94^{\circ} \mathrm{C}\right.$ for $\left.30 \mathrm{~s}\right)$, annealing $\left(55^{\circ} \mathrm{C}\right.$ for $30 \mathrm{sec}$ ), and elongation $\left(68^{\circ} \mathrm{C}\right.$ for $\left.1 \mathrm{~min}\right)$.

All RT-PCR products were evaluated by using direct DNA sequencing for their identification.

\subsubsection{Separation of DNA fragments on standard agarose-gels}

Solutions for the agarose-gel electrophoresis:

TBE electrophoresis buffer (10x): $0.89 \mathrm{M}$ Tris (108 g), $0.89 \mathrm{M}$ boric acid (55 g), and $40 \mathrm{ml} 0.5 \mathrm{M}$ EDTA, pH 8.0, filled up to 1 I with $\mathrm{ddH}_{2} \mathrm{O}$

Loading buffer (10x): 20\% (w/v) Ficoll 400, 0.1 M EDTA, pH 8.0, 1\% SDS, and 0.25\% $(\mathrm{w} / \mathrm{v})$ bromophenol blue 


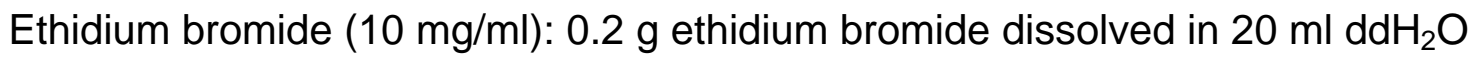

The DNA fragments were separated in 1.5\% agarose gels $(20 \mathrm{~cm} \times 8 \mathrm{~cm} \times 1 \mathrm{~cm})$. $2.25 \mathrm{~g}$ agarose was dissolved in $150 \mathrm{ml}$ TBE buffer, melted in a microwave, evenly mixed, cooled to about $55^{\circ} \mathrm{C}$, and poured into a sealed gel casting platform. After removing the comb, the gel was covered with electrophoresis buffer. Loading buffer was added to the DNA samples (final $1 \mathrm{x}$ ) and applied as a thin layer at the bottom of the wells. The power supply was connected to the cell and ran at 1 to $10 \mathrm{~V} / \mathrm{cm}$ of gel. To visualise the DNA, the gel was stained for $30 \mathrm{~min}$ in $0.5 \mu \mathrm{g} / \mathrm{ml}$ ethidium bromide, destained in water, placed on a UV light source, and finally photographed. DNA markers served as reference.

\subsubsection{DNA isolation and quantification}

The DNA fragments were extracted from the gel using the QIAquick ${ }^{\circledR}$ Gel Extraction Kit. The gel slice containing the DNA band was precisely excised. One to two volumes of diffusion buffer was added to 1 volume of gel and incubated at $50^{\circ} \mathrm{C}$ for 30 min with occasional vortexing. The sample was centrifuged for 1 min and the supernatant was carefully removed which was then passed through a disposable plastic column containing a Whatman GF/C filter to remove any residual gel. Three volumes of Buffer QG was added to 1 volume of supernatant and mixed afterwards. If the colour of the mixture was orange or violet, $10 \mu \mathrm{l} 3 \mathrm{M}$ sodium acetate, $\mathrm{pH} 5.0$ was added. The sample was applied to a QIAquick Spin Column to bind the DNA followed by a centrifugation step for 30 - $60 \mathrm{~s}$. After the flowing-through was discarded, the column was washed with $0.75 \mathrm{ml}$ Buffer PE and centrifuged for $30-60$ s. The flowing-through was discarded again, and the column was centrifuged for an additional $1 \mathrm{~min}$ at maximal speed $(16,000 \mathrm{rpm})$. For the elution of the DNA, the QIAquick Spin Column was placed into a clean 1.5-ml tube, and $50 \mu \mathrm{l}$ Buffer EB (10 $\mathrm{mM}$ Tris $/ \mathrm{HCl}, \mathrm{pH}$ 8.5) was applied to the membrane of the column which was followed by a centrifugation for 1 min. Finally, the purified DNA was stored at $-70^{\circ} \mathrm{C}$. The DNA concentration was estimated by spectrophotometry $\left(1 \mathrm{OD}_{260}\right.$ unit corresponds to about $50 \mu \mathrm{g} / \mathrm{ml}$ dsDNA or $38 \mu \mathrm{g} / \mathrm{ml}$ ssDNA) and the size of the isolated DNA by comparison with DNA markers equally treated by agarose gel electrophoresis.

\subsubsection{In-situ hybridisation}

The principle of the in-situ hybridisation is the specific annealing of a labelled nucleic acid probe to complementary sequences in fixed tissue in which the non-degraded target nucleic acid is retained in-situ and accessible for the hybridisation to the probe. Thus, the in-situ hybridisation technique allows for identification of specific mRNA expressions in their cellular environment. 


\subsection{Subcloning of DNA fragments}

The cloning of specific DNA fragments into appropriate vectors allows for production of unlimited amounts of the insert-DNA, whereas the hybrid plasmid is propagated by bacteria.

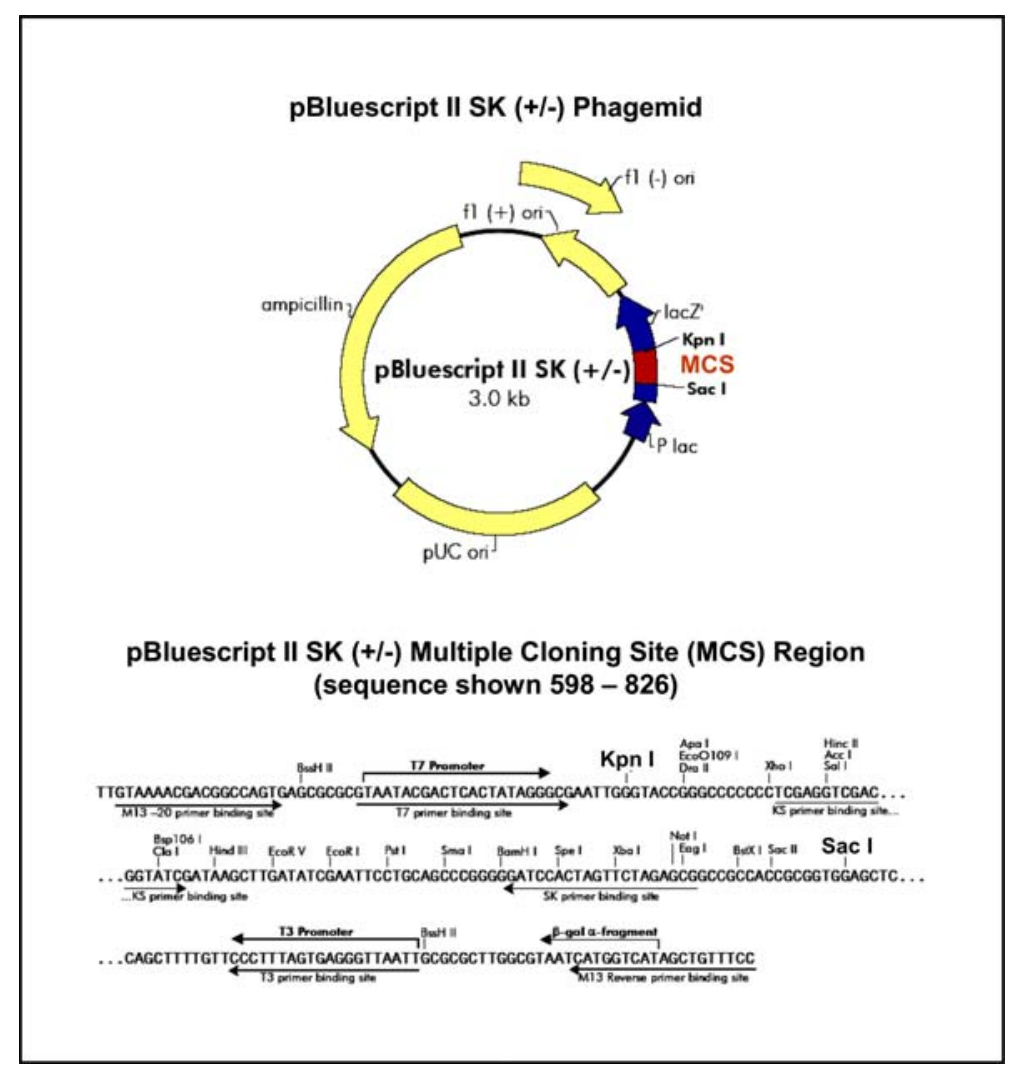

Figure 13. pBluescript SK (+l-) vector: the pBluescript is a phagemid vector with a polylinker in the alpha region of the lacZ gene and T3 and T7 promoter sequences flanking the cloning sites. The pBluescript SK (+) vector has the f1 filamentous phage ori in the (+) orientation, allowing recovery of the sense strand of the lacZ gene as ssDNA. pBluescript SK (-) has the $f 1$ ori in the opposite orientation, allowing recovery of the other strand. The position of the polylinker in the lacZ alpha region allows for identification of inserts based on a blue/white colour screen under the appropriate conditions. The T3 and T7 promoters are recognised by bacteriophage RNA polymerases, allowing transcription of inserted DNA to be initiated from either side of the polylinker.

\subsection{Dephosphorylation of the plasmid}

The pBluescript SK (+/-) vector (fig. 13) was initially linearised with the restriction enzymes Kpn I or Sac I which recognise the sequence $5^{\prime}-G G T A C \downarrow C-3^{\prime}$ or $5^{\prime}$ GAGCT $\downarrow C-3^{\prime}$ and generate fragments with $3^{\prime}$-cohesive termini. The $5^{\prime}$-phosphate residues were removed with alkaline phosphatase to prevent self-ligation. Five micro-

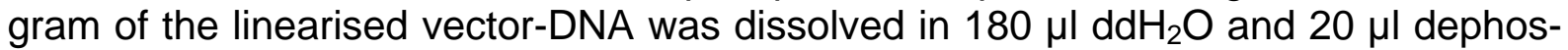
phorylation buffer [0.5 M Tris/HCl (10x), pH 8.0]. Nought point five units of alkaline phosphatase per microgram DNA was added and incubated for $30 \mathrm{~min}$ at $37^{\circ} \mathrm{C}$. The enzyme activity was inhibited by the application of $2 \mu \mathrm{l} 0.1 \mathrm{M}$ EDTA and incubation for $15 \mathrm{~min}$ at $65^{\circ} \mathrm{C}$. To eliminate the proteins, the sample was washed twice with an equal volume of chloroform/isoamyl alcohol (24:1). The DNA was subsequently precipitated with 0.1 volume of $3 \mathrm{M}$ sodium acetate and three volumes of $99.9 \%$ ethanol for $30 \mathrm{~min}$ at $70^{\circ} \mathrm{C}$, centrifuged, washed with $70 \%$ ethanol, vacuum dried, and finally resuspended in $\mathrm{dd}_{2} \mathrm{O}$. 


\subsection{Preparation of the DNA fragment}

The specific cDNA (for sequence see UniProt, primary accession number P32304) of the mouse $5-\mathrm{HT}_{7}$ receptor isoform was cleaved via restriction enzymes on position 123 with Sac I and on position 548 with $\mathrm{Kpn} \mathrm{I}(1 \mu \mathrm{g}$ cleaved DNA/unit of the enzyme in $1 \mathrm{~h}$ at $37^{\circ} \mathrm{C}$ in a total volume of $25 \mu \mathrm{l}$ of the provided digestion buffer) resulting in a DNA fragment of $425 \mathrm{bp}$. The DNA was separated using an agarose-gel (see 2.2.5.2.5.), and finally extracted from the gel (see 2.2.5.2.6.).

\subsection{Ligation}

The correspondence between the ends of both the DNA fragment and the vector is a precondition for the complementary linkage via phosphodiester bonds. One hundred microgram vector-DNA, 200 - 500 ng insert-DNA, $4 \mu$ ligation buffer (5x) [5 mM ATP, $50 \mathrm{mM} \mathrm{MgCl}, 75 \mathrm{mM}$ DTT, $0.33 \mathrm{M} \mathrm{Tris} / \mathrm{HCl}(\mathrm{pH} 7.6)$, and $500 \mu \mathrm{g}$ gelatine/ $\mu \mathrm{l}]$, and 2 units of T4-ligase (DNA ligases catalyse the formation of phosphodiester bonds between juxtaposed $5^{\prime}$-phosphate and 3 '-hydroxyl termini in duplex DNA) were incubated for $14-16$ hours at $12^{\circ} \mathrm{C}$. The preparation $(20 \mu \mathrm{l}$ of total volume $)$ could be directly used for the transformation.

\subsection{Preparation of competent cells}

The Escherichia coli strain JM 109 [Yanisch-Perron et al. (1985)] was used for the propagation of the DNA fragment. One millilitre of a fresh $10-\mathrm{ml}$ bacterial culture was inoculated into $100 \mathrm{ml}$ LB-medium [1.0\% (w/v) bacto-trypton, 0.5\% (w/v) yeast extract, $0.5 \%(\mathrm{w} / \mathrm{v})$ maltose, and $0.5 \%(\mathrm{w} / \mathrm{v}) \mathrm{NaCl}, \mathrm{pH} 7.0]$. The cells were incubated with shaking at $37^{\circ} \mathrm{C}$ until an $\mathrm{OD}_{600}$ of $0.6-0.9$ was reached. The growth was terminated by incubation for $30 \mathrm{~min}$ on ice. After the cells had been centrifuged for 5 min at $4,000 \mathrm{rpm}$, the sediment was resuspended in $5 \mathrm{ml}$ ice-cold $50 \mathrm{mM} \mathrm{CaCl}$ solution followed by incubation for 10 - 24 hours on ice. After glycerine was added (15\% final concentration), the bacteria were aliquoted $(100 \mu \mathrm{l})$ and subsequently stored at $-70^{\circ} \mathrm{C}$.

\subsection{Transformation}

The 20- $\mu$ l batch of the ligation (see 2.2.5.3.1.3.) was mixed with $50 \mu$ l of competent cells and incubated for $30 \mathrm{~min}$ on ice. After an incubation for $2-3 \mathrm{~min}$ at $42^{\circ} \mathrm{C}, 200 \mu \mathrm{l}$ LB-medium was added and incubated for at least $30 \mathrm{~min}$ at $37^{\circ} \mathrm{C}$. Finally, the bacterial suspension was spread on ampicillin-containing LB-agar plates and incubated at $37^{\circ} \mathrm{C}$ overnight to select the ampicillin-resistant bacteria which grow in white colonies.

\subsection{Isolation of the plasmid-DNA with TELT-buffer}

Several colonies of the transformed bacteria of the $\mathrm{LB}_{\mathrm{amp}}$-agar plate were transferred to $2.5 \mathrm{ml} \mathrm{LB}$ amp solution (0.1 $\mathrm{\mu g}$ ampicillin/ml LB-medium) and incubated with continuous shaking for at least 8 hours at $37^{\circ} \mathrm{C}$. The bacterial culture was centrifuged for $30 \mathrm{~s}$ at $16,000 \mathrm{rpm}$, the supernatant was discharged, and the cells were then 
resuspended in $150 \mu \mathrm{l}$ TELT buffer $[0.25 \mathrm{ml} 1 \mathrm{M}$ Tris/ $\mathrm{HCl}, \mathrm{pH} 7.5,0.625 \mathrm{ml} 0.5 \mathrm{M}$ EDTA, $0.2 \mathrm{ml} 5 \%$ Triton X-100, and $3.93 \mathrm{ml} 3.2 \mathrm{M} \mathrm{LiCl}$. Fifteen microlitre lysozyme (10 $\mu \mathrm{g}$ lysozyme/ $\mu \mathrm{lddH_{2 }}$ ) was added for $2 \mathrm{~min}$ at $95^{\circ} \mathrm{C}$ followed by cooling on ice and centrifugation for $10 \mathrm{~min}$ at $16,000 \mathrm{rpm}$. The DNA of the supernatant was precipitated with 0.6 volumes of isopropanol at RT and immediately centrifuged at $16,000 \mathrm{rpm}$ for $15 \mathrm{~min}$ at $4^{\circ} \mathrm{C}$. The DNA sediment was washed with $70 \%$ ethanol, shortly vacuum dried, and resuspended afterwards with $40 \mu \mathrm{ldd} \mathrm{H}_{2} \mathrm{O}$. Ten microlitre of the prepared plasmid-DNA was cleaved with the restriction enzymes Kpn I or Sac I, treated with $2 \mu \mathrm{l}$ RNase $(10 \mu \mathrm{g} / \mu \mathrm{l})$ for $15 \mathrm{~min}$ at $37^{\circ} \mathrm{C}$, and separated using agarose-gel electrophoresis to test the correct insertion of the DNA fragment. After a phenol/chloroform extraction of the plasmid-DNA, it was sequenced for its identification and then compared via BLAST (NCBI).

\subsubsection{Non-radioactive labelling of RNA probes with digoxigenin (DIG)}

For the transcription of DNA fragments into labelled RNA, the DNA fragments have to be cloned into the Bluescript vector which possess both a T3- and a T7-RNA polymerase primer binding site (fig. 13). Before the transcription the hybrid plasmid was linearised and separated from the non-linearised plasmid by agarose gel electrophoresis. The DNA was then isolated from the gel. The labelling was performed using the DIG RNA Labelling Mix: $1 \mu \mathrm{g}$ DNA, $2 \mu \mathrm{l}$ labelling mix, $2 \mu$ l transcription buffer, $1 \mu \mathrm{l}$ RNase inhibitor, and $2 \mu \mathrm{l}$ of adequate RNA polymerase were made up to $20 \mu \mathrm{l}$ with DEPC-treated water and incubated for 2 hours at $37^{\circ} \mathrm{C}$. The reaction was terminated with $2 \mu \mathrm{l} 0.2 \mathrm{M}$ EDTA followed by precipitation of the RNA with $2.4 \mu \mathrm{l} 4 \mathrm{M}$ $\mathrm{LiCl}$ and $75 \mu \mathrm{l} 99.9 \%$ ethanol for $30 \mathrm{~min}$ at $-70^{\circ} \mathrm{C}$. After centrifugation at $16,000 \mathrm{rpm}$ for 30 min at $4^{\circ} \mathrm{C}$, the sediment was washed with $50 \mu \mathrm{l} 70 \%$ ethanol, vacuum dried, resuspended in $100 \mu \mathrm{L}$ DEPC-treated water, and incubated afterwards for $20 \mathrm{~min}$ at $37^{\circ} \mathrm{C}$. The efficiency of the labelling was tested by a dot blot analysis in which the provided labelled RNA with known concentration served as standard. After the standard RNA and the sample RNAs were diluted (1:5,1:20, and $1: 100), 1 \mu \mathrm{l}$ of each dilution was dotted onto a nylon-membrane, dried, and fixed by UV-light irradiation.

\subsection{Non-radioactive detection with AP-conjugated anti-DIG antibodies}

The non-radioactive detection was performed using an AP-conjugated antibody directed against the hapten digoxigenin (DIG). The membrane was equilibrated with buffer I [0.1 M Tris/ $\mathrm{Hcl}(\mathrm{pH} 7.5)$ and $0.15 \mathrm{M} \mathrm{NaCl}]$ for $5 \mathrm{~min}$ at RT. Buffer II (2\% FCS and $0.3 \%$ Triton X-100 dissolved in buffer I) was applied for 30 min to block the nonspecific binding sites followed by the incubation in AP-conjugated anti-DIG antibody solution (diluted $1: 5,000$ in buffer II) for $30 \mathrm{~min}$. The membrane was washed twice afterwards with buffer I for 15 min each followed by a wash with buffer III [0.1 M Tris/ $\mathrm{HCl}(\mathrm{pH} 9.5), 0.1 \mathrm{M} \mathrm{NaCl}$, and $50 \mathrm{mM} \mathrm{MgCl} 2$ ]. The membrane was finally treated with developing solution [45 $\mu \mathrm{l}$ NBT $(75 \mu \mathrm{g} / \mu \mathrm{l}$ of $70 \%$ DMF) and $35 \mu \mathrm{l} \mathrm{BCIP}(50 \mu \mathrm{g} / \mu \mathrm{l}$ of DMF) dissolved in $10 \mathrm{ml}$ buffer III] for $10 \mathrm{~min}$ to visualise the antigen-antibody reaction. The development was terminated with $\mathrm{dd}_{2} \mathrm{O}$, and the membrane was dried afterwards and finally photographed. 


\subsection{In-situ hybridisation on paraffin sections}

Solutions for the hybridisation :

Denhardt's solution (100x): 2\% BSA, 2\% PVP, and 2\% Ficoll

SSC (30x): $4.5 \mathrm{M} \mathrm{NaCl}$ and $0.45 \mathrm{M}$ sodium citrate

TE (10x): $0.1 \mathrm{M}$ Tris, pH 8.0 and 10 mM EDTA

Prehybridisation solution: $50 \%$ deionised formamide, $10 \%$ dextransulfate, Denhardt's solution (1x), $0.5 \mu \mathrm{g} / \mu \mathrm{l}$ E.coli DNA (denatured for $5 \mathrm{~min}$ at $95^{\circ} \mathrm{C}$ ), $0.25 \mu \mathrm{g} / \mu \mathrm{l}$ yeast tRNA, $0.5 \mu \mathrm{g} / \mu \mathrm{l}$ yeast $\mathrm{r}-\mathrm{RNA}$, and SSC (4x)

The paraffin sections were deparaffinised by heating at $60^{\circ} \mathrm{C}$, directly transferred to xylene, rehydrogenated with decreasing ethanol concentrations $(3 \times 99.9 \%, 3 \times 95 \%$, $3 \times 80 \%$, and $3 \times 70 \%$ ) for 5 min each, and rinsed three times with PBS. The proteases were inhibited by application of $0.1 \mathrm{M}$ glycine/PBS for $5 \mathrm{~min}$ at RT. The sections were permeabilised with $0.2 \%$ Triton X-100 for 15 min, washed three times with PBS, and treated with protein kinase $\mathrm{K}(10 \mu \mathrm{g} / \mathrm{ml})$ for $30 \mathrm{~min}$ at $37^{\circ} \mathrm{C}$. For the removal of the proteinase $\mathrm{K}$ and the post-fixation of the sections, $4 \%$ paraformaldehyde solution was applied for $5 \mathrm{~min}$ at RT. Freshly prepared $0.25 \%$ acetic anhydride/0.1 M triethyl-amine $(\mathrm{pH} 8.0)$ was used to reduce the background of the staining. The sections were treated with prehybridisation solution for at least $1 \mathrm{~h}$, which was replaced by hybridisation solution containing 25 - $100 \mathrm{ng}$ anti-sense probe/ $\mu \mathrm{l}$, and incubated overnight at $42^{\circ} \mathrm{C}$. The sections were applied afterwards with RNase solution ( $20 \mu \mathrm{g}$ RNase diluted in $1 \mathrm{ml} \mathrm{TE}$ ) for $30 \mathrm{~min}$ at $42^{\circ} \mathrm{C}$, and rinsed twice for 30 min each at $42^{\circ} \mathrm{C}$ with different SSC dilutions in the following order: SSC (2x), SSC $(0.1 \mathrm{x})$ and SSC (0.05x). The detection was basically performed as described above (2.2.5.3.4.) with the application of the developing solution excepted overnight in the dark and with the termination of the development with buffer IV (10 mM Tris/ $\mathrm{HCl}, \mathrm{pH} 8.0$ and $1 \mathrm{mM}$ EDTA). At last, the sections were dehydrogenated with increasing concentrations of ethanol ( $3 \times 70 \%, 3 \times 80 \%, 3 \times 95 \%$, and $3 \times 99.9 \%)$ for 5 min each, cleared with four changes of xylene, coverslipped with DePeX, and finally analysed with the AxioVision system (Zeiss). Equally treated sections were applied with the sense-probe and served as negative controls. 


\subsubsection{Physiology}

\subsubsection{Electrophysiology}

\subsubsection{Patch-clamp recordings}

Patch electrodes were pulled from borosilicate glass capillaries (Biomedical Instruments, Zülpich, Germany) on a horizontal pipette-puller (Zeitz-Instruments, Germany) and filled with $0.125 \mathrm{M} \mathrm{K}$-gluconate, $1 \mathrm{mM} \mathrm{CaCl}, 2 \mathrm{mM} \mathrm{MgCl}, 4 \mathrm{mM}$ $\mathrm{Na}_{2} \mathrm{ATP}, 10 \mathrm{mM}$ EGTA, and $10 \mathrm{mM}$ HEPES (pH value was adjusted to 7.2 with $\mathrm{KOH})$. Their resistance ranged from 2 to $6 \mathrm{M} \Omega$. Respiratory neurones and astrocytes were patched under visual control. Following the formation of a gigaseal, brief suction was applied to establish the whole-cell configuration. Whole cell voltage clamp recordings were performed using a Multiclamp 700 patch-clamp amplifier (Axon Instruments Inc., Foster City, CA, USA), low-pass filtered at $3 \mathrm{kHz}$, and sampled at $10 \mathrm{kHz}$ using an interface (Digidata 1320) and pClamp 8.2 software (Axon Instruments, Inc., Foster City, CA). The series resistance and cell membrane capacitance were compensated before experiments. Respiratory drive currents and potentials were measured in the voltage clamp (holding potential: $-70 \mathrm{mV}$ ) and current clamp mode, respectively. Only inspiratory neurones, i.e. neurones displaying burst of action potentials in synchrony with hypoglossal nucleus or preBötzinger complex burst discharges, were filled with biocytin and subsequently used for immunohistochemistry. Glia cells were identified from membrane potentials that were more negative than $-75 \mathrm{mV}$, low input resistance, and by a lack of action potential discharge during positive current injection. While performing the electrophysiological recordings, the identified cells were filled with a pipette solution containing $0.5 \%$ biocytin for 20 - $30 \mathrm{~min}$. A short pulse of positive pressure was applied to carefully disconnect the pipette from the cell, and the pipette was then slowly removed from the slice.

\subsection{Biocytin imaging}

After submerging the slices in freshly prepared filtered $4 \%$ phosphate-buffered formaldehyde for 2 hours, they were transferred to $30 \%$ sucrose in $0.1 \mathrm{M}$ phosphate buffer and stored for at least 12 hours at $4{ }^{\circ} \mathrm{C}$. Transverse $80-\mu \mathrm{m}$-thick slices were cut, rinsed three times in PBS ( $\mathrm{pH}$ 7.4) for 15 min each, permeabilised with $0.2 \%$ Triton X-100 for $1 \mathrm{~h}$ at RT, incubated in primary antibody solution $(1: 100-1: 500$ in $5 \%$ BSA/PBS) for 48 hours at $4{ }^{\circ} \mathrm{C}$, and washed three times afterwards with PBS. The slices were incubated with fluorochrome-conjugated secondary antibody solution ( $1: 200-1: 400$ in $5 \%$ BSA/PBS) for 4 hours at RT in the dark, extensively washed with PBS, mounted onto slides, coverslipped with fluorescent mounting medium, and finally analysed with the confocal laser-scanning microscope Meta-LSM 510. 


\subsubsection{In-vivo experiments}

The in-vivo studies were performed in accordance with the ethical guidelines for the care and use of animals and was approved by the local council for animal care. All animals were housed under controlled environmental conditions with 12-hours lightdark cycles. Sprague Dawley rats of either sex (250 - $350 \mathrm{~g})$ were anaesthetised by intraperitoneal injection of pentobarbital $(60 \mathrm{mg} / \mathrm{kg})$. The appropriate anaesthesia was tested by repeatedly pinching the forepaw. In case of complex reflex responses, an additional amount of pentobarbital was applied (1/10 of the initial doseage). The femoral vein, femoral artery, and the trachea were canulated with polyethylene tubing. Drugs and fluids were injected into the vein. The blood pressure (only for the serotonin $2 \mathrm{~A}$ and $2 \mathrm{~B}$ receptor isoform experiments) and the respiratory airflow (inspiration/expiration) were recorded using a MacLab-linked pressure transducer connected to the arterial or tracheal tubing. Nociceptive responses were assessed by the tail-flick response (TF). High intensity light was applied to the marked spots $(1 \mathrm{~cm}$ from the tip, 4 spots at an interval of $1 \mathrm{~cm}$ ), and the TF was quantified by electronical measurement of the latency from 'heat on to the evoked withdrawal response. The average TF response latency values of 3 consecutive trails before drug application were used as baseline. To avoid severe tissue damage, the heating was stopped when the TF latency was exceeding $300 \%$ of the baseline concluding TF response abolishment. To prevent central hypoxia, the animals were insufflated with oxygen during the whole experiment and artificially ventilated at low frequency (10 - 15 breath/min) after opioid-induced apnoea. The artificial ventilation was immediately stopped after the detection of first signs of stabilising spontaneous breathing evoked by drug application. All animals were sacrificed by an overdose of pentobarbital.

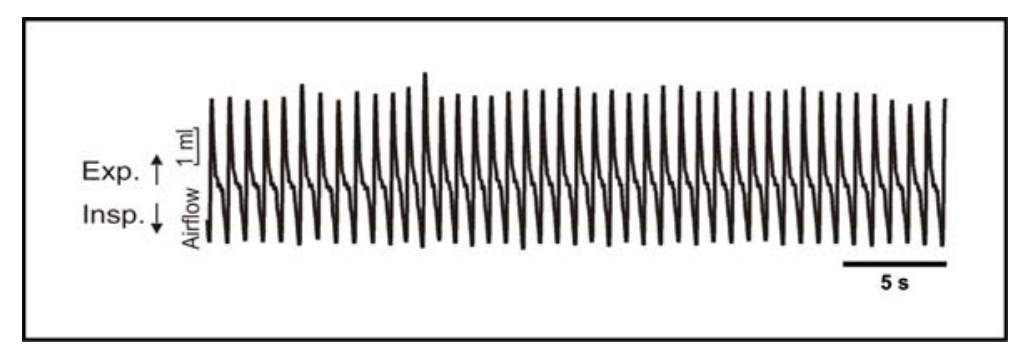

Figure 14. Trace of breathing pattern under pentobarbital anaesthesia $(60 \mathrm{mg} / \mathrm{kg})$ : the respiratory airflow (inspiration $\downarrow /$ expiration $\uparrow$ ) was recorded using a MacLab-linked pressure transducer connected to the tracheal tubing

Table 3. Pharmacological substances for the in-vivo studies: the drugs were dissolved in $\mathrm{ddH}_{2} \mathrm{O}$ except for BW 723C86 and GR 113808 which were dissolved in $10 \mathrm{mM}$ DMSO. The prepared stock solutions had a concentration of $1 \mu \mathrm{g} / \mu \mathrm{l}$ and were stored at $-20^{\circ} \mathrm{C}$.

\begin{tabular}{|c|c|c|c|c|}
\hline Target receptor & Agonist & {$[\mathbf{m g} / \mathbf{k g}]$} & Antagonist & {$[\mathbf{m g} / \mathbf{k g}]$} \\
\hline $5-\mathrm{HT}_{2 \mathrm{~A}} \mathrm{R}$ & $\alpha-$ methyl-5-HT & 0.1 & Ketanserin & 1 \\
\hline $5-\mathrm{HT}_{2 \mathrm{~B}} \mathrm{R}$ & $\mathrm{BW} 723 \mathrm{C} 86$ & 1 & LY 272015 & 1 \\
\hline $5-\mathrm{HT}_{1 \mathrm{~A}} \mathrm{R}$ & $8-\mathrm{OH}-\mathrm{DPAT}$ & 0.1 & WAY-100635 & 1 \\
\hline $5-\mathrm{HT}_{4(\mathrm{a})} \mathrm{R}$ & $\mathrm{BIMU-8}$ & 1 & GR 113808 & 1 \\
\hline $5-\mathrm{HT}_{7} \mathrm{R}$ & & & SB 269970 & 1 \\
\hline$\mu-\mathrm{OR}$ & Fentanyl & 0.01 & Naloxone & 1 \\
\hline
\end{tabular}




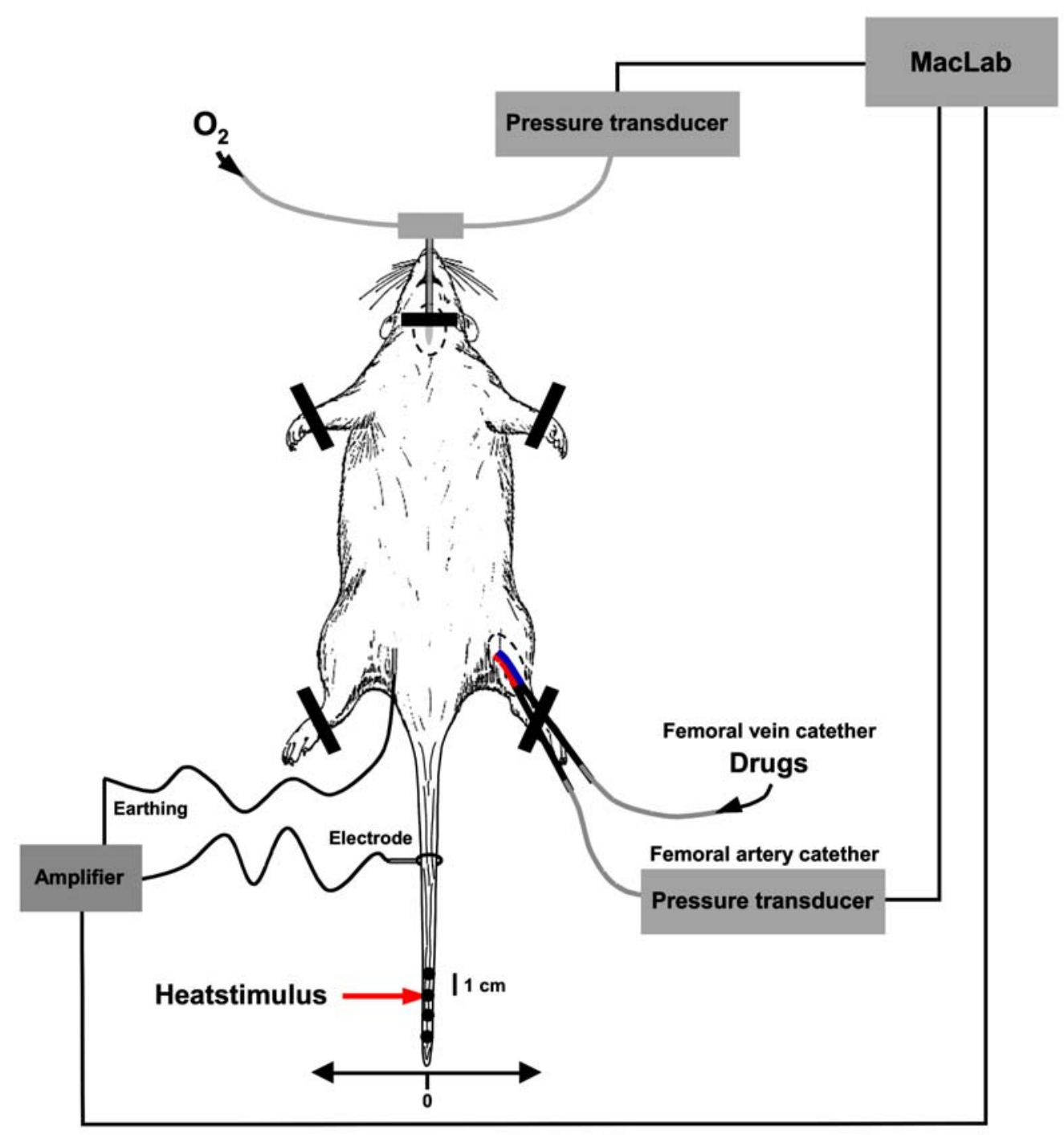

Figure 15. Experimental set-up for the in-vivo studies: the drugs were applied through the femoral vein catether (marked with blue colour). The femoral artery catether (marked with red colour) was connected to a pressure transducer linked to a MacLab system for recording the blood pressure. The respiratory airflow (inspiration/expiration) was recorded using a tracheal tubing connected to a pressure transducer which was also linked to the MacLab system. Oxygen was insufflated during the whole experiment to prevent hypoxia. The tail-flick response latency was measured electronically from 'heat on'. The heatstimulus (red arrow) was applied to the marked spots.

\subsubsection{Statistical analysis}

Pharmacological effects on breathing were quantified by comparing respiratory minute volume 1 min before and 2 - 3 min after consecutive drug application. For the analysis of the tail-flick (TF) response latency, the mean value of 3 trails before and after each drug application was used. Statistical significance was tested with a paired students t-test, whereas a 95\% confidence limit was taken as being significant. Linear functions (e.g. BSA standard curve) were tested by linear regression. 


\section{Results}

\subsection{Production and characterisation of poly- and monoclonal antibodies}

\subsubsection{Production and characterisation of polyclonal anti-serotonin 4(a), 7, and 2B receptor isoform antibodies}

The mouse and rat belong to the same subfamily Murinae, family Muridae. As the evolutionary proximity may restrict the antibody response, specific polyclonal antipeptide antibodies directed against the rat serotonin $4(\mathrm{a}), 7$, and $2 \mathrm{~B}$ receptor isoforms were produced in rabbits which are evolutionarily more distant [Goding (1996), Howard and Bethell (2001), Harlow and Lane (1988)].

\subsubsection{Sequence alignment and peptide-selection and -coupling}

After receptor alignment and calculation of the antigenic indices, the peptide sequences were selected from the rat receptor isoform sequence regarding to specificity for each receptor and greatest possible conformity between the mouse and rat peptide sequences to increase the probability that the antibodies will also recognise the mouse receptor isoform.

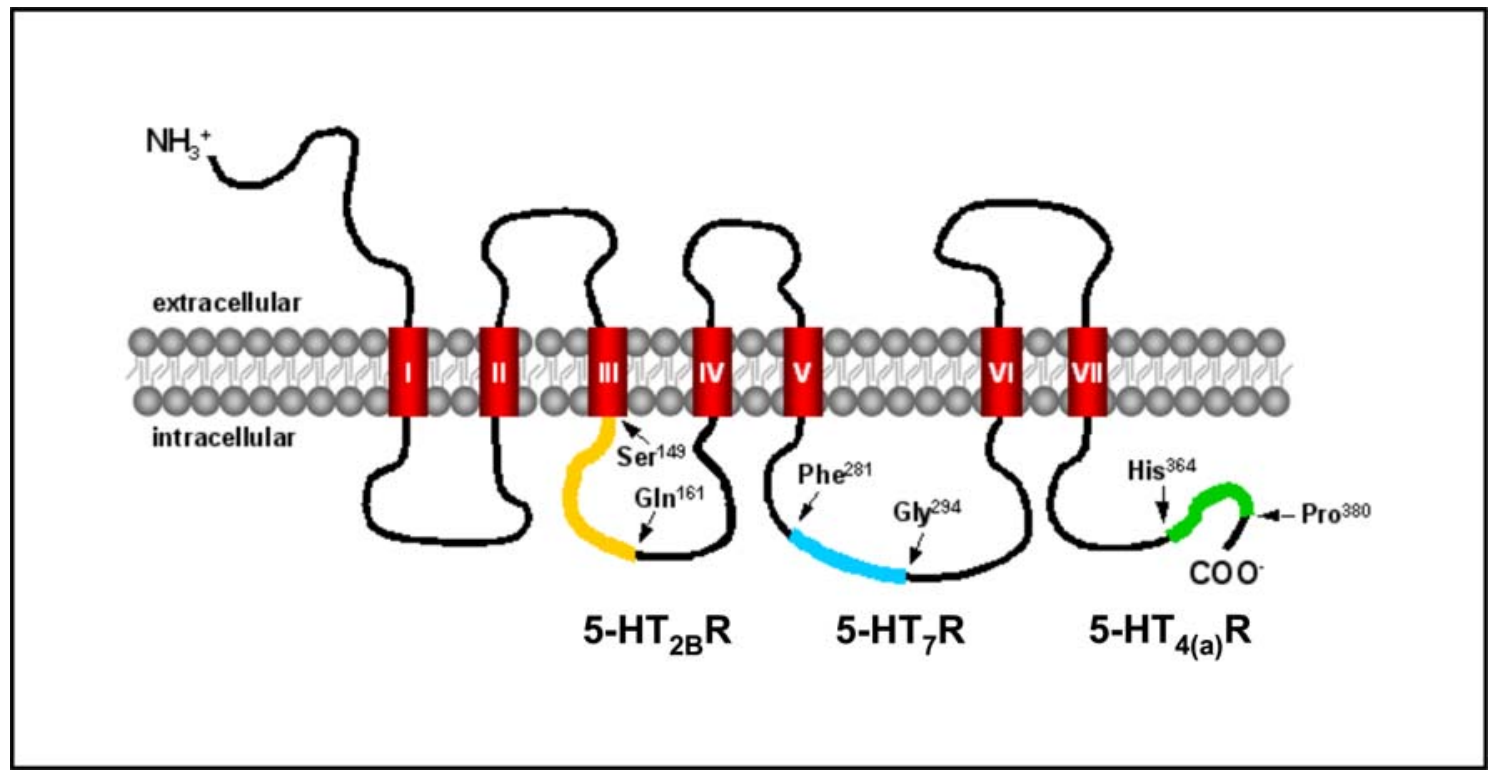

Figure 16. Schematic representation of selected peptide sequences for the immunisation: the serotonin receptor isoforms belong to the family of seven-transmembrane-domain receptors which are coupled to different hetero-trimeric G-proteins except for the $5-\mathrm{HT}_{3}$ receptor which functions as a transmitter-gated $\mathrm{Na}^{+} / \mathrm{K}^{+}$channel. The transmembrane domains are indicated by red cylinders (I - VII). The selected peptides for the immunisation are derived from the second intracellular loop (5- $\mathrm{HT}_{2 \mathrm{~B}}$ receptor isoform, peptide $\mathrm{NH}_{2}$-CAISLDRYIAIKKPIQ-COOH, marked with yellow colour), the third intracellular loop (5- $\mathrm{HT}_{7}$ receptor isoform, peptide $\mathrm{NH}_{2}-\mathrm{FPRVQPESVISLNG-COOH}$, marked with blue colour), and the C-terminal domain (5- $\mathrm{HT}_{4(\mathrm{a})}$ receptor isoform, peptide $\mathrm{NH}_{2}-\mathrm{HSGQHQELEKLPIHNDP-}$ $\mathrm{COOH}$, marked with green colour), respectively. 
Serotonin 4(a) receptor isoform alignment: Since the 5- $\mathrm{HT}_{4(\mathrm{a})}$ receptor isoform is a Cterminal splice variant of the $5-\mathrm{HT}_{4}$ receptor, the peptide which had been chosen for the immunisation was derived from the C-terminal domain of the rat $5-\mathrm{HT}_{4(\mathrm{a})}$ receptor isoform sequence $\left(\mathrm{NH}_{2}-\mathrm{HSGQHQELEKLPIHNDP-COOH}\right)$.

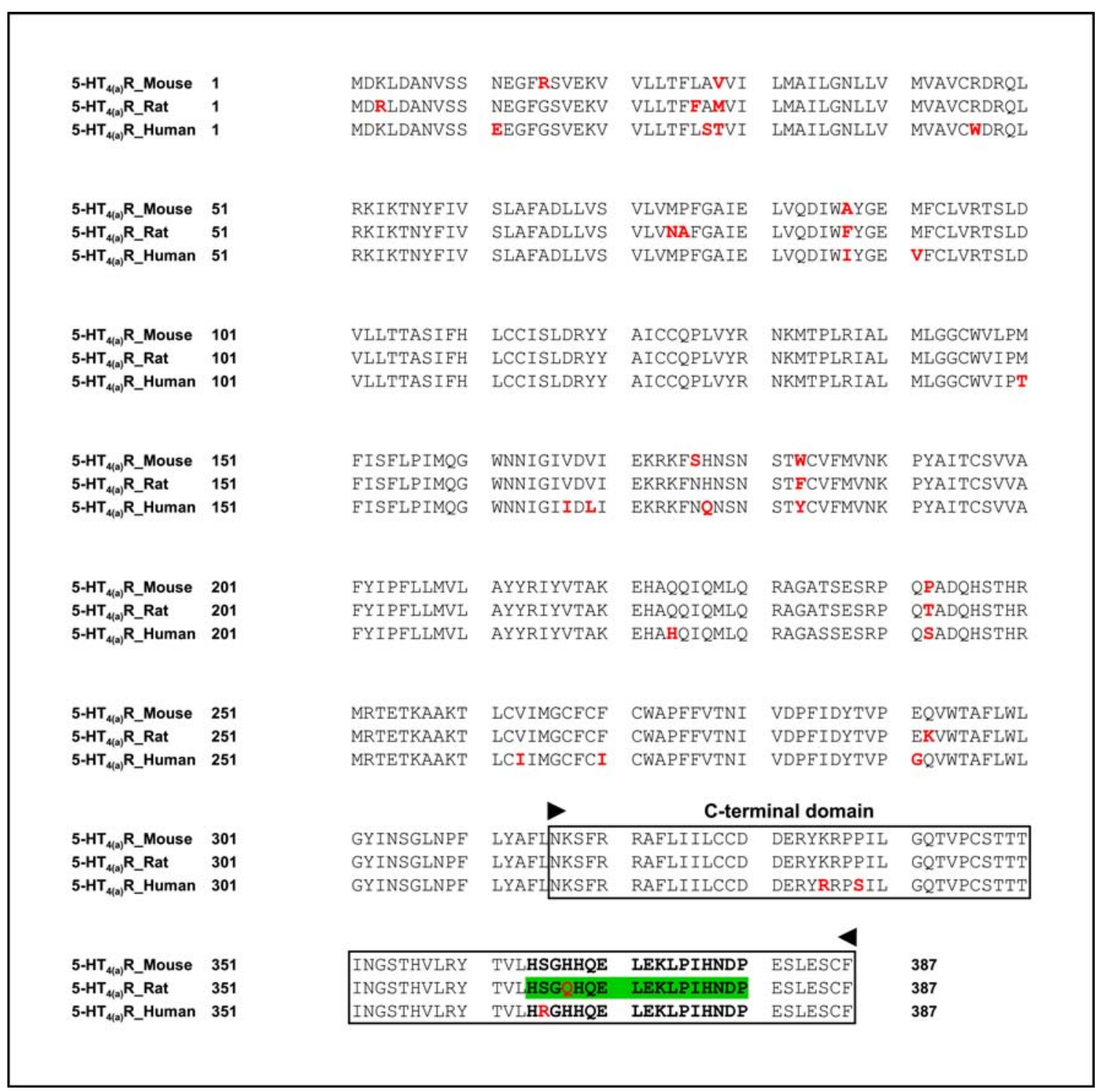

Figure 17. Serotonin 4(a) receptor isoform alignment: the homologies between the amino acid sequences in the range of $1-387$ are $96.9 \%$ for the sequences of mouse and rat, $94.6 \%$ for the sequences of mouse and man, and $93.5 \%$ for the primary structure of rat and man. The mismatches are indicated by red letters, and the peptide $\mathrm{NH}_{2}-\mathrm{HSGQHQELEKLPIHNDP-COOH}$, which was used for the immunisation, is marked with green colour. There is only one mismatch between the peptide sequences of mouse, rat, and man. The specificity of the selected peptide sequences was tested using the GCG (Genetic Computing Group) programme BLAST. 
Serotonin 7 receptor isoform alignment: The specific peptide for immunisation was derived from the third intracellular loop of the rat $5-\mathrm{HT}_{7}$ receptor isoform sequence $\left(\mathrm{NH}_{2}\right.$-FPRVQPESVISLNG-COOH) which is supposed to be the binding domain of the G-protein.

\begin{tabular}{|c|c|c|c|c|c|c|}
\hline 5-HT, R_Mouse & 1 & MMDVNSSGRP & DLYGHLRSLI & LPEVGRRLQD & LSPDGGAHSV & VSSWMPHLLS \\
\hline 5-HT, $\mathrm{R}_{-}$Rat & 1 & MMDVNSSGRP & DLYGHLRSLI & LPEVGRGLQD & LSPDGGAHPV & VSSWMPHLLS \\
\hline 5-HT $\mathrm{H}_{7} \mathrm{R}_{-}$Human & 1 & MMDVNSSGRP & DLYGHLRSFL & LPEVGRGLPD & LSPDGGADPV & AGSWAPHLLS \\
\hline 5-HT, R_Mouse & 51 & GFPEVTASPA & PTWDAPPDNV & SGCGEQINYG & RVEKVVIGSI & LTLITLLTIA \\
\hline 5-HT, R_Rat & 51 & GFLEVTASPA & PTWDAPPDNV & SGCGEQINYG & RVEKVVIGSI & LTLITLLTIA \\
\hline 5-HT, $R \_$Human & 51 & EVTASPA & PTWDAPPDNA & SGCGEQINYG & RVEKVVIGSI & LTLITLLTIA \\
\hline 5-HT $\mathrm{R}_{-}$Mouse & 101 & GNCLVVISVC & FVKNVRQPSN & YLIVSLALAD & LSVAVAVMPF & VSVTDLIGGK \\
\hline 5-HT, R_Rat & 101 & GNCLVVISVC & FVKKLRQPSN & YLIVSLALAD & LSVAVAVMPF & VSVTDLIGGK \\
\hline 5-HT, R_Human & 98 & GNCLVVISVC & FVKKLRQPSN & YLIVSLALAD & LSVAVAVMPE & VSVTDLIGGK \\
\hline 5-HT, R_Mouse & 151 & WIFGHFFCNV & FIAMDVMCCT & ASIMTLCVIS & IDRYLGITRP & LTYPVRQNGK \\
\hline 5-HT_R_Rat & 151 & WIFGHFFCNV & FIAMDVMCCT & ASIMTLCVIS & IDRYLGITRP & LTYPVRQNGK \\
\hline 5-HT, $\mathrm{R}_{-}$Human & 148 & WIFGHFFCNV & FIAMDVMCCT & ASIMTLCVIS & IDRYLGITRP & LTYPVRQNGK \\
\hline 5-HT, R_Mouse & 201 & CMAKMILSVW & PLSASITLPP & LFGWAQNVND & DKVCLISQDF & GYTIYSTAVA \\
\hline & 201 & CMAKMILSVW & LLSASITLPP & LFGWAQNVND & DKVCLISQDF & GYTIYSTAVA \\
\hline \multirow{2}{*}{ 5-HT, R_Human } & 198 & CMAKMILSVW & LLSASITLPP & LFGWAQNVND & DKVCLISQDF & GYTIYSTAVA \\
\hline & & & $\rightarrow$ & \multicolumn{2}{|c|}{ third intracellular loop } & \\
\hline 5-HT, R_Mouse & 251 & FYIPMSVMLF & MYY QIYKAAR & KSAAKHKFSG & FPRVQPESVI & SLNGVVKLQR \\
\hline 5-HT, $R_{-}$Rat & 251 & FYIPMSVMLF & MYYQIYKAAR & KSAAKHKFPG & FPRVQPESVI & SLNGVVKLQK \\
\hline 5-HT, $\mathrm{R}_{-}$Human & 248 & FYIPMSVMLF & MYYEIYKAAR & KSAAKHKFPG & FPRVEPDSVI & ALNGIVKLQK \\
\hline 5-HT,R_Mouse & 301 & EVEECANLSR & LLKHERKNIS & SFKREQKAAT & TLGIIVGAFT & VCWLPFFLLS \\
\hline 5-HT, R_Rat & 301 & EVEECANLSR & LLKHERKNIS & IFKREQKAAT & TLGIIVGAFT & VCWLPFFLLS \\
\hline 5-HT, $\mathrm{R}_{-}$Human & 298 & EVEECANLSR & LLKHERKNIS & IFKREQKAAT & TLGIIVGAFT & VCWLPFFLLS \\
\hline 5-HT, R_Mouse & 351 & TARPFICGTS & CSCIPLWVER & TCLWLGYANS & LINPFIYSFF & NRDLRTTYRS \\
\hline 5-HT, $\mathrm{R}_{-}$Rat & 351 & TARPFICGTS & CSCIPLWVER & TCLWLGYANS & LINPFIYAFF & NRDLRTTYRS \\
\hline 5-HT, $\mathrm{R}_{-}$Human & 348 & TARPFICGTS & CSCIPLWVER & TFLWLGYANS & LINPFIYAFF & NRDLRTTYRS \\
\hline 5-HT, R_Mouse & 401 & LLQCQYRNIN & RKLSAAGMHE & ALKLAERPER & SEFVLQNCDH & CGKKGHDT $\mathbf{4 4 8}$ \\
\hline 5-HT, R_Rat & 401 & LLQCQYRNIN & RKLSAAGMHE & ALKLAERPER & SEFVLQNSDH & CGKKGHDT $\mathbf{4 4 8}$ \\
\hline 5-HT, $\mathrm{R}_{-}$Human & 398 & LLQCQYRNIN & RKLSAAGMHE & ALKLAERPER & PEFVLRACTR & RVLLRPEKRP \\
\hline $\begin{array}{l}\text { 5-HT, R_Mouse } \\
5-\mathrm{HT}_{7} \mathrm{R}_{-} \text {Rat }\end{array}$ & $\begin{array}{l}449 \\
449\end{array}$ & & & & & \\
\hline 5-HT $\mathrm{HT}_{7} \mathrm{R}_{-}$Human & 448 & PVSVWVLQSP & DHHNWLADKM & LTTVEKKVMI & HD 479 & \\
\hline
\end{tabular}

Figure 18. Serotonin 7 receptor isoform alignment: the rate of homology between the amino acid sequences of mouse and rat (amino acids 1 - 448) are 97.8\%, 89.3\% for mouse and man, and 93.3\% for the rat and man. The human $5-\mathrm{HT}_{7}$ receptor isoform amino acid sequence consists of 31 additional amino acids in comparison with the mouse and rat sequences. The mismatches are indicated by red letters. The peptide $\mathrm{NH}_{2}$-FPRVQPESVISLNG-COOH, which was used for the immunisation, is marked with blue colour and shows complete homology with the mouse amino acid sequence. In contrast, 3 mismatches exist between the peptide sequences of rat and man. The specificity of the selected peptide sequence was tested using the GCG programme BLAST. 
Serotonin 2B receptor isoform alignment: The peptide which was used for the immunisation was derived from the second intracellular loop of the rat $5-\mathrm{HT}_{2 \mathrm{~B}}$ receptor isoform $\left(\mathrm{NH}_{2}\right.$-CAISLDRYIAIKKPIQ-COOH).

\begin{tabular}{|c|c|c|c|c|c|c|}
\hline 5- $\mathrm{HT}_{2 \mathrm{~B}} \mathrm{R}_{-}$Mouse & 1 & MASSYKMSE & QSTTSEHILQ & KTCDHLILTN & RSGLETDSVA & EEMKQTVEGQ \\
\hline 5- $\mathrm{HT}_{2 \mathrm{~B}} \mathrm{R}_{-}$Rat & 1 & MASSYKMSE & QSTISEHILQ & KTCDHLILTD & RSGLKAESAA & EEMKQTAENQ \\
\hline 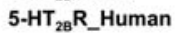 & 1 & MALSYRVSEL & QSTIPEHILQ & STFVHVISSN & WSGLQTESIP & EEMKQIVEEQ \\
\hline 5- $\mathrm{HT}_{2 \mathrm{~B}} \mathrm{R}_{-}$Mouse & 50 & GHTVHWAALL & ILAVI IPTIG & GNILVILAVA & LEKRLQYATN & YFLMSLAIAD \\
\hline 5- $\mathrm{HT}_{2 \mathrm{~B}} \mathrm{R} \_$Rat & 50 & GNTVHWAALL & IFAVIIPTIG & GNILVILAVS & LEKRLQYATN & YFLMSLAVAD \\
\hline 5- $\mathrm{HT}_{2 \mathrm{~B}} \mathrm{R} \_$Human & 51 & GNKLHWAALL & ILMVI I PTIG & GNTLVILAVS & LEKKLQYATN & YFLMSLAVAD \\
\hline 5- $\mathrm{HT}_{2 \mathrm{~B}} \mathrm{R} \_$Mouse & 100 & LLVGLFVMPI & ALLTIMFEAI & WPLPLALCPA & WLFLDVLFST & ASIMHLCAI \\
\hline 5- $\mathrm{HT}_{2 \mathrm{~B}} \mathrm{R}_{-}$Rat & 100 & LLVGLFVMPI & ALLTIMFEAT & WPLPLALCPA & WLFLDVLFST & ASIMHLCAI \\
\hline \multirow[t]{2}{*}{ 5- $\mathrm{HT}_{2 \mathrm{~B}} \mathrm{R} \_$Human } & 101 & LLVGLFVMPI & ALLTIMFEAM & WPLPLVLCPA & WLFLDVLFST & ASIMHLCAI \\
\hline & & \multicolumn{2}{|c|}{ second intracellular loop } & & & \\
\hline 5-HT ${ }_{2 \mathrm{~B}} \mathrm{R} \_$Mouse & 149 & SLDRYIAIKKP & IQANQCNTRA & TAFIKITVVW & LISIGIAIPV & PIKGIETDVI \\
\hline 5- $\mathrm{HT}_{2 \mathrm{~B}} \mathrm{R}_{-}$Rat & 149 & SLDRYIAIKKP & IQANQCNSRT & TAFVKITVVW & LISIGIAIPV & PIKGIEADVV \\
\hline 5- $\mathrm{HT}_{2 \mathrm{~B}} \mathrm{R}_{-}$Human & 150 & SVDRYIAIKKP & IQANQYNSRA A & TAFIKITVVW & LISIGIAIPV & PIKGIETDVD \\
\hline 5-HT ${ }_{2 \mathrm{~B}} \mathrm{R} \_$Mouse & 200 & NPHNVTCELT & KDRFGSFMVF & GSLAAFFVPL & TIMVVTYFLT & IHTLQKKAYL \\
\hline 5- $\mathrm{HT}_{2 \mathrm{~B}} \mathrm{R} \_$Rat & 200 & NAHNITCELT & KDRFGSFMLF & GSLAAFFAPL & TIMIVTYFLT & IHALRKKAYL \\
\hline 5- $\mathrm{HT}_{2 \mathrm{~B}} \mathrm{R} \_$Human & 201 & NPNNITCVLT & KERFGDFMLF & GSLAAFFTPL & AIMIVTYFLT & IHALQKKAYL \\
\hline 5-HT ${ }_{28} \mathrm{R} \_$Mouse & 250 & VKNKPPQRLT & RWTVPTVFLR & EDSSFSSPEK & VAMLDGSHRD & KILPNSSDET \\
\hline 5-HT ${ }_{2 \mathrm{~B}} \mathrm{R} \_$Rat & 250 & VRNRPPQRLT & RWTVSTVLQR & EDSSFSSPEK & MVMLDGSHKD & KILPNSTDET \\
\hline 5- $\mathrm{HT}_{2 \mathrm{~B}} \mathrm{R} \_$Human & 251 & VKNKPPQRLT & WLTVSTVFQR & DETPCSSPEK & VAMLDGSRKD & KALPNSGDET \\
\hline 5- $\mathrm{HT}_{28} \mathrm{R} \_$Mouse & 300 & LMRRMSSVGK & RSAQTISNEQ & RASKALGVVF & FLFLLMWCPF & FITNLTLALC \\
\hline 5- $\mathrm{HT}_{2 \mathrm{~B}} \mathrm{R} \_$Rat & 300 & LMRRMSSAGK & KPAQTISNEQ & RASKVLGIVF & LFFLLMWCPF & FITNVTLALC \\
\hline 5- $\mathrm{HT}_{2 \mathrm{~B}} \mathrm{R}_{-}$Human & 301 & LMRRTSTIGK & KSVQTISNEQ & RASKVLGIVF & FLFLLMWCPF & FITNITLVLC \\
\hline 5-HT $\mathrm{HT}_{2 \mathrm{~B}} \mathrm{R}_{\text {M Mouse }}$ & 350 & DSCNQTTLKT & LLEIFVWIGY & VSSGVNPLIY & TLFNKTFREA & FGRYITCNYR \\
\hline 5- $\mathrm{HT}_{2 \mathrm{~B}} \mathrm{R} \_$Rat & 350 & DSCNQTTLKT & LLQIFVWVGY & VSSGVNPLIY & TLFNKTFREA & FGRYITCNYQ \\
\hline 5- $\mathrm{HT}_{2 \mathrm{~B}} \mathrm{R} \_$Human & 351 & DSCNQTTLQM & LLEIFVWIGY & VSSGVNPLVY & TLFNKTFRDA & FGRYITCNYR \\
\hline 5- $\mathrm{HT}_{28} \mathrm{R} \_$Mouse & 400 & ATKSVKALRK & FSSTLCFGNS & MVENSKFFTK & HGIRNGINPA & MYQSPMRLRC \\
\hline 5- $\mathrm{HT}_{2 \mathrm{~B}} \mathrm{R} \_$Rat & 400 & ATKSVKVLRK & CSSTLYFGNS & MVENSKFFTK & HGIRNGINPA & MYQSPVRLRS \\
\hline 5- $\mathrm{HT}_{2 \mathrm{~B}} \mathrm{R} \_$Human & 401 & ATKSVKTLRK & RSSKIYFRNP & MAENSKFFKK & HGIRNGINPA & MYQSPMRLRS \\
\hline 5- $\mathrm{HT}_{2 \mathrm{~B}} \mathrm{R} \_$Mouse & 450 & STIQSSSIIL & LDT LLTEND & GDKAEEQVSY & ILQERAGLIL & REGDEQDARA \\
\hline 5- $\mathrm{HT}_{2 \mathrm{~B}} \mathrm{R}$ _Rat & 450 & STIQSSSIIL & LNT FLTEND & GDKVEDQVSY & I & 479 \\
\hline 5- $\mathrm{HT}_{2 \mathrm{~B}} \mathrm{R} \_$Human & 451 & STIQSSSIIL & LDTLLLTENE & GDKTEEQVSY & $\mathrm{v}$ & 481 \\
\hline $5-\mathrm{HT}_{2 \mathrm{~B}} \mathrm{R} \_$Mouse & 499 & PWQVQE & 504 & & & \\
\hline 5- $\mathrm{HT}_{2 \mathrm{~B}} \mathrm{R}$-Rat & 480 & & & & & \\
\hline 5- $\mathrm{HT}_{2 \mathrm{~B}} \mathrm{R} \_$Human & 482 & & & & & \\
\hline
\end{tabular}

Figure 19. Serotonin 2B receptor isoform alignment: the homologies between the amino acid sequences in the range of $1-479$ are $89.3 \%$ for the sequences of mouse and rat, $83.7 \%$ for the sequences of mouse and man, and $81.8 \%$ for the primary structure of rat and man. The mouse receptor isoform amino acid sequence consists of 25 additional amino acids in comparison with the rat sequence. The mismatches are indicated by red letters. The peptide $\mathrm{NH}_{2}$-CAISLDRYIAIKKPIQ$\mathrm{COOH}$, which was used for immunisation, is marked with yellow colour and shows complete homology with the mouse sequence, whereas only one mismatch exist between the man peptide sequence. The specificity of the selected peptide sequences was tested using the GCG programme BLAST. 
The selected peptides for the immunisation were coupled to both $\mathrm{KLH}$ and BSA (see 2.2.1.2.). The efficiency of the coupling procedure was tested with the BSA-conjugated peptides by Coomassie blue staining of the SDS-PAG. The separated BSAconjugated peptides appeared as a typical smear in which the relative molecular mass ranged from about 65 to $110 \mathrm{kDa}$ indicating sufficient coupling (fig. 20). The relative molecular mass of the uncoupled BSA, which served as a reference, was about $65 \mathrm{kDa}$.

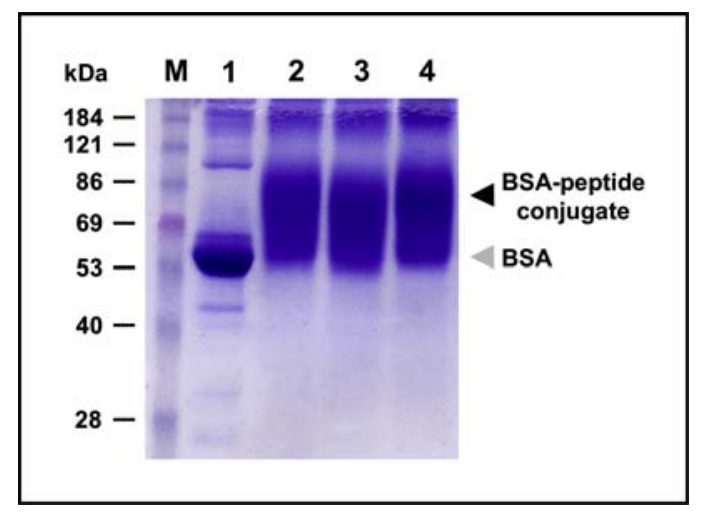

Figure 20. Coomassie blue staining of the SDS-PAG which contains the separated BSAcoupled peptides: the total protein concentration of each sample was estimated using the Lowry assay. Twenty microgram of unconjugated BSA as reference [lane 1], $20 \mu \mathrm{g}$ of HSGQHQELEKLPIHNDP-coupled BSA (5- $\left.\mathrm{HT}_{4(\mathrm{a})} \mathrm{R}\right)$ [lane 2], $20 \mu \mathrm{g}$ of FPRVQPESVISLNG-coupled BSA (5- $\left.\mathrm{HT}_{7} \mathrm{R}\right)$ [lane 3], or $20 \mu \mathrm{g}$ of CAISLDRYIAIKKPIQ-coupled BSA (5- $\left.\mathrm{HT}_{2 \mathrm{~B}} \mathrm{R}\right)$ [lane 4] was separated using a $12 \% \mathrm{SDS}$ PAG.

\subsubsection{Antibody titre of the antisera from rabbits}

Three WNZ-rabbits for each peptide were immunised as described in 2.2.1.3., and the antibody titre of each was determined after the third and fifth immunisation using an ELISA with solid phase-coated peptide. Only antisera with an antibody titre exceeding $1: 256,000$ after the fifth immunisation were selected for the antibody purification. The $5-\mathrm{HT}_{4(\mathrm{a})}$ receptor isoform antibody titre was $1: 128,000$ after the third immunisation and increased to $1: 512,000$ after the fifth immunisation (rabbit 2). The $5-\mathrm{HT}_{7}$ and $5-\mathrm{HT}_{2 \mathrm{~B}}$ receptor isoform antibody titres increased from $1: 256,000$ to 1 : $1,024,000$ after the fifth immunisation (rabbits 6 and 8).

Table 4. Determination of the polyclonal antibody titre: the first blood sample was taken before any immunisation and served as reference. The second (third) blood sample was taken after the third (fifth) immunisation.

\begin{tabular}{|c|c|c|c|}
\hline Species & Antigen & \multicolumn{2}{|c|}{ Antibody titre } \\
\hline Rabbit & & after the $3^{\text {rd }}$ immunisation & after the $5^{\text {th }}$ immunisation \\
\hline 1 & \multirow{3}{*}{$\begin{array}{l}\text { HSGQHQELEKLPIHNDP } \\
(\text { Rat 5-HT } 4(\mathrm{a}) \\
\text { R) }\end{array}$} & $1: 32,000$ & $1: 128,000$ \\
\hline 2 & & $1: 128,000$ & $1: 512,000$ \\
\hline 3 & & $1: 4,000$ & $1: 32,000$ \\
\hline 4 & \multirow{3}{*}{$\begin{array}{l}\text { FPRVQPESVISLNG } \\
\text { (Rat 5-HT7R) }\end{array}$} & $1: 16,000$ & $1: 32,000$ \\
\hline 5 & & $1: 64,000$ & $1: 512,000$ \\
\hline 6 & & $1: 256,000$ & $1: 1,024,000$ \\
\hline 7 & \multirow{3}{*}{$\begin{array}{l}\text { CAISLDRYIAIKKPIQ } \\
\left.\text { (Rat 5- } \mathrm{HT}_{2 \mathrm{~B}} \mathrm{R}\right)\end{array}$} & $1: 32,000$ & $1: 128,000$ \\
\hline 8 & & $1: 256,000$ & $1: 1,024,000$ \\
\hline 9 & & $1: 8,000$ & $1: 128,000$ \\
\hline
\end{tabular}




\subsubsection{Purification of the polyclonal antibodies from serum of rabbits}

The diluted polyclonal antisera of the hyperimmunised rabbits $2\left(5-\mathrm{HT}_{4(\mathrm{a})} \mathrm{R}\right), 6$ (5$\left.\mathrm{HT}_{7} \mathrm{R}\right)$, and $8\left(5-\mathrm{HT}_{2 \mathrm{~B}} \mathrm{R}\right)$ were purified by affinity chromatography on protein $\mathrm{A}-$ sepharose using the 'low-salt method (see 2.2.1.5.) which was followed by affinity chromatography using CNBr-activated Sepharose 4B-coupled peptide (see 2.2.1.6.) to produce so-called monospecific anti-peptide polyclonal IgG antibodies. The homogeneity of the purified peptide-specific IgG molecules was shown by Coomassie blue staining of a gel in which only the heavy (55 kDa) and light chains ( $25 \mathrm{kDa})$ of the $\lg \mathrm{G}$ molecules were stained (fig. 21).

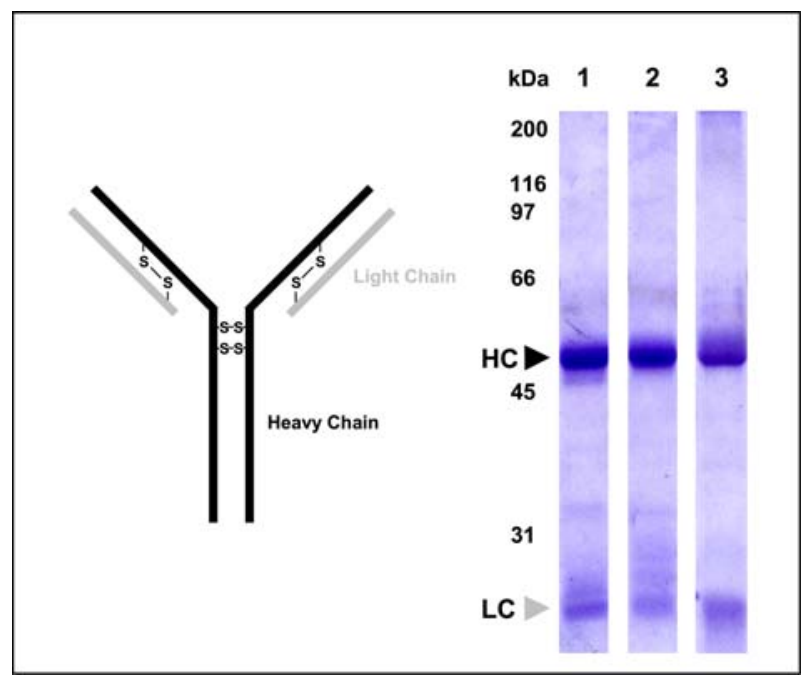

Figure 21. Coomassie blue staining of the SDS-PAG which contains the monospecific antipeptide IgG molecules: the protein concentration of each sample was estimated using the Lowry assay. Ten microgram of anti-5- $\mathrm{HT}_{7} \mathrm{R}$ antibodies (lane 1), $10 \mu \mathrm{g}$ of anti-5- $\mathrm{HT}_{4(\mathrm{a})} \mathrm{R}$ antibodies (lane 2), or $10 \mu \mathrm{g}$ of anti-5- $\mathrm{HT}_{2 \mathrm{~B}} \mathrm{R}$ antibodies (lane 3) was separated under reducing conditions using 2-mercaptoethanol which reduces the disulfide bonds (-S-S-) of the IgG molecules. Only the heavy (HC 55 $\mathrm{kDa}$, black arrowhead) and light chains (LC $25 \mathrm{kDa}$, grey arrowhead) were visible. On the left side, a model of an IgG molecule is shown.

\subsubsection{Characterisation of the polyclonal antibodies recognising the serotonin 4(a), 7, and 2B receptor isoforms}

\subsection{Anti-serotonin 4(a) receptor antibody}

The peptide-specific anti-5- $\mathrm{HT}_{4(\mathrm{a})}$ receptor antibodies were tested for specificity using the Western blot technique, immunohisto- /cytochemistry, and an ELISA with solid phase-coated antigen (see 3.1.3.). The anti-5- $\mathrm{HT}_{4(\mathrm{a})}$ receptor antibody reaction showed a single band of about $46 \mathrm{kDa}$ which corresponds with the predicted molecular mass of the 5- $\mathrm{HT}_{4(\mathrm{a})}$ receptor (fig. 22A). Immunofluorescence analysis of N1E-115 cells which had been transiently transfected with the murine $5-\mathrm{HT}_{4(\mathrm{a})} \mathrm{R}-\mathrm{GFP}$ plasmid indicated a strong co-labelling of the 5-HT $4(\mathrm{a}) \mathrm{R}-\mathrm{GFP}$ and the anti-5- $\mathrm{HT}_{4(\mathrm{a})}$ receptor antibody staining. The non-transfected N1E-115 wild-type cells did not reveal any $5-\mathrm{HT}_{4(\mathrm{a})}$ receptor immunoreactivity (IR) (fig. 22C). This result was in accordance with the RT-PCR analysis which indicated that the non-transfected N1E-115 cells did not express the 5- $\mathrm{HT}_{4(\mathrm{a})} \mathrm{R}$-specific mRNA (fig. 22B). Furthermore, the specific $5-\mathrm{HT}_{4(\mathrm{a})} \mathrm{R}$-IR in neurones of rat brainstem slices was blocked after pre-incubation of the primary antibody with a 50-fold molar excess of the peptide HSGQHQELEKLPIHNDP which had been used for the immunisation. 
A

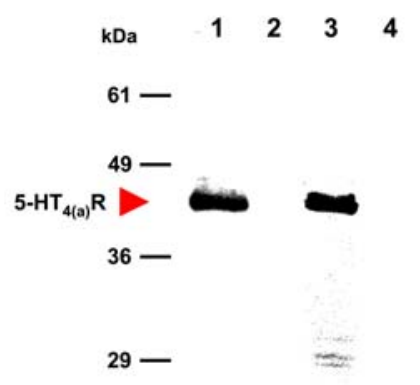

B

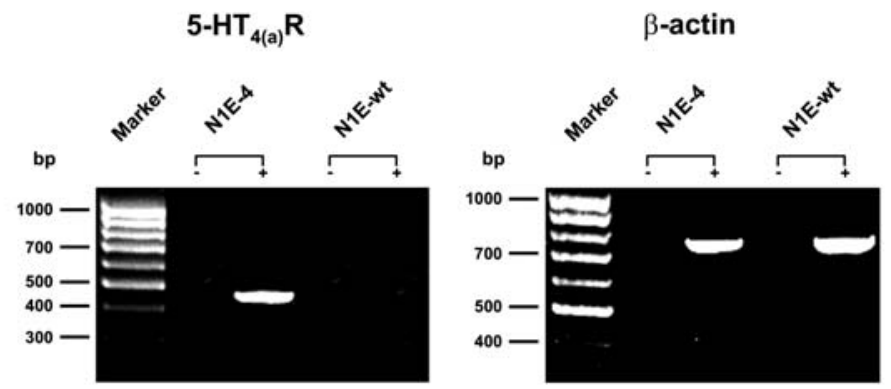

C
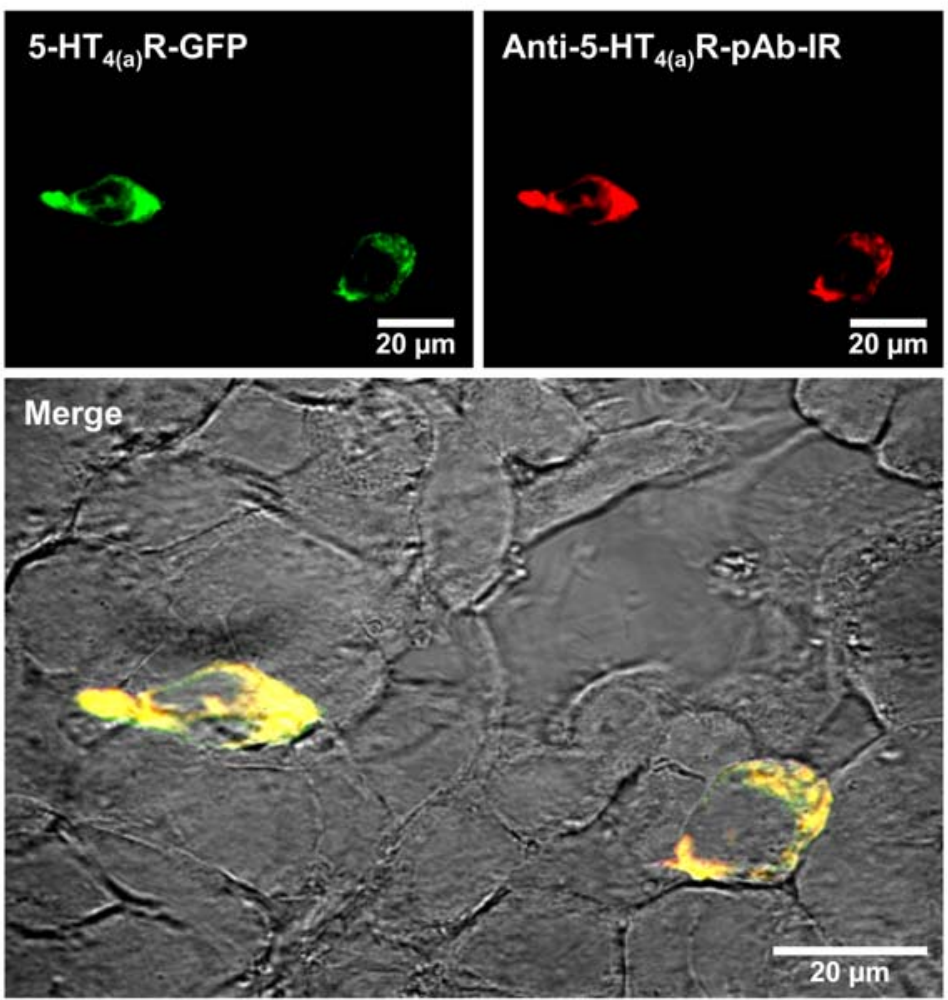

Figure 22. Test of the specificity of the peptide-specific anti-5-HT $4(\mathrm{a}) \mathrm{R}$ antibody:

(A) immunoblot analysis: the lysis of the cells was performed using the detergent Triton X-114. One hundred microgram protein of the membrane fraction of N1E-115 cells which had been transiently transfected with the murine 5- $\mathrm{HT}_{4(\mathrm{a})}$ receptor (lane 1), $100 \mu \mathrm{g}$ protein of the cytosolic fraction of transfected N1E-115 cells (lane 2), $150 \mu \mathrm{g}$ protein of the membrane fraction of total rat brainstem (lane 3), or $150 \mu \mathrm{g}$ protein of the cytosolic fraction of total rat brainstem (lane 4) was separated using a $12 \%$ SDS-PAG. The antibody detected a single band of about $46 \mathrm{kDa}$ in the membrane fractions which corresponds with the predicted molecular mass of the receptor.

(B) RT-PCR analysis of transfected and non-transfected N1E-115 cells: the transfected N1E-115 cells (N1E-4) expressed the mRNA specific for the murine 5- $\mathrm{HT}_{4(\mathrm{a})}$ receptor (amplicon size $460 \mathrm{bp}$ ), whereas the non-transfected cells (N1E-wt) did not. Samples without reverse transcriptase (RT) served as negative controls (-). The 'housekeeping gene' $\beta$-actin was used as an internal standard (amplicon size $769 \mathrm{bp}$ ). All RT-PCR products were partially sequenced for their identification.

(C) immunocytochemistry: the staining with the anti-5- $\mathrm{HT}_{4(\mathrm{a})} \mathrm{R}$ antibody followed by a secondary Cy5-conjugated anti-rabbit antibody (red colour) indicated a strong co-labelling only with N1E-115 cells which had been transiently transfected with the murine $5-\mathrm{HT}_{4(\mathrm{a})} \mathrm{R}-\mathrm{GFP}$ (green colour). 


\subsubsection{Anti-serotonin 7 receptor antibody}

The monospecific polyclonal anti-5- $\mathrm{HT}_{7}$ receptor antibody was tested for specificity using the Western blot technique, immunohisto- /cytochemistry, FACS analysis, and an ELISA with solid phase-coated antigen (see 3.1.3.). Furthermore, the antibodydependent receptor labelling of cells within different rat brain regions (immunohistochemistry) was compared with the $5-\mathrm{HT}_{7}$ receptor-specific mRNA expression which had been identified using in-situ-hybridisation. The patterns of expression on the mRNA and protein level were completely in accordance.

The FACS analyses of permeabilised RBL cells showed a fluorescence signal (fig. 23Aa), whereas non-permeabilised RBL cells did not (fig. 23Ab). Consequently, the polyclonal anti-5- $\mathrm{HT}_{7} \mathrm{R}$ antibody, which is directed against an intracellular epitope, did not show unspecific cross-reactivities with an epitope on the extracellular surface of the RBL cells.

The RT-PCR analysis of wild-type rat basophilic leucocytes (RBL-wt) indicated the expression of the murine $5-\mathrm{HT}_{7} \mathrm{R}$-specific mRNA (fig. 23B) which was in accordance with immunocytochemical analyses of the RBL-wt cells (fig. 23C). The 5- $\mathrm{HT}_{7} \mathrm{R}$-IR in RBL-wt cells was blocked after pre-incubation of the primary antibody with a 50 -fold molar excess of the peptide FPRVQPESVISLNG, which had been used for the immunisation, indicating specific labelling.

In the cerebellum e.g., the antibody recognised the receptor only in the Purkinje cells which expressed the $5-\mathrm{HT}_{7}$ receptor-specific mRNA as identified by in-situ-hybridisation (fig. 23D). Cells which did not express the $5-\mathrm{HT}_{7} \mathrm{R}$-specific mRNA did not reveal any specific antibody-dependent immunoreactivity.

Using Sf.9 cells which had been transiently transfected with the murine $5-\mathrm{HT}_{7} \mathrm{R}$, the anti-5- $\mathrm{HT}_{7}$ receptor antibody recognised a single band of about $48 \mathrm{kDa}$ which corresponds with the predicted molecular mass of the $5-\mathrm{HT}_{7}$ receptor (fig. 23E). In contrast, the antibody did not reveal a specific signal using non-transfected Sf.9 cells.

Furthermore, the data of the monoclonal anti-5- $\mathrm{HT}_{7} \mathrm{R}$ antibody $5 \mathrm{HT} 7 \mathrm{R} / 220$ (see 3.1.2.), which had been generated against the same peptide, confirmed the specificity of the monospecific polyclonal anti-5- $\mathrm{HT}_{7} \mathrm{R}$ antibody. 
A a

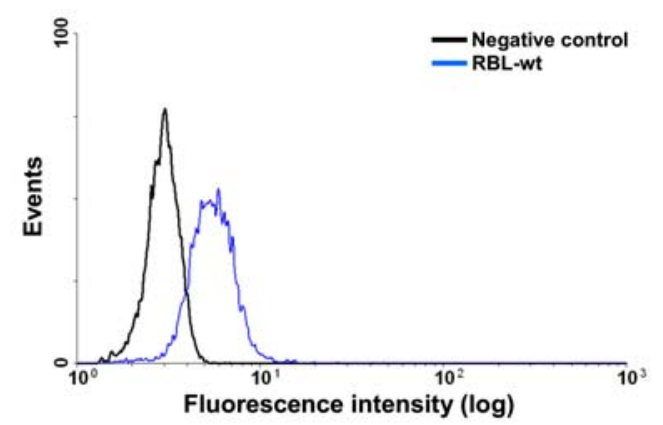

B

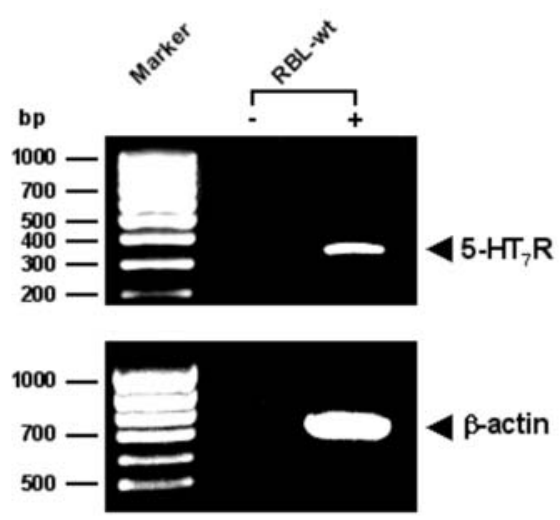

b

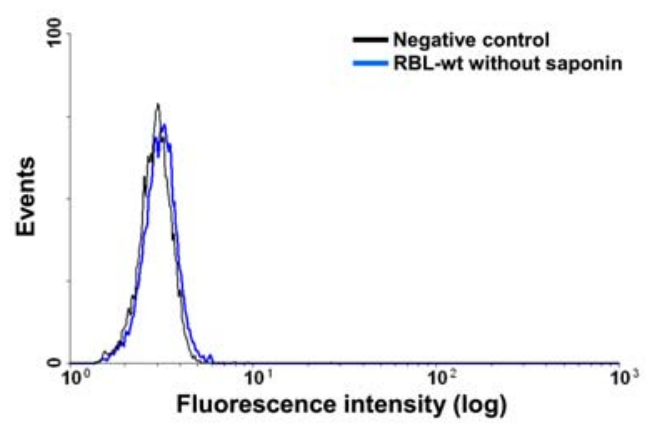

C

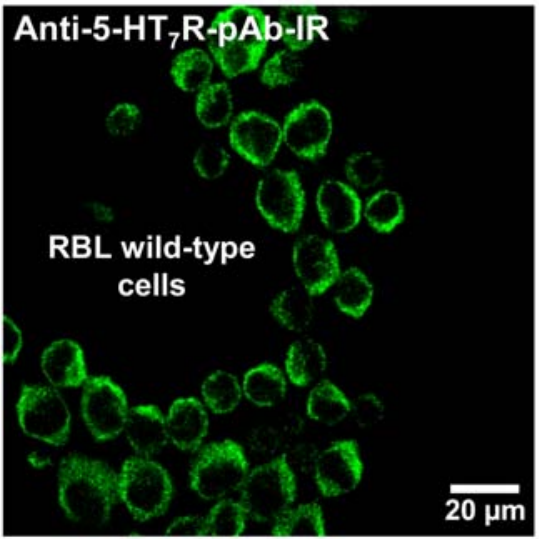

D

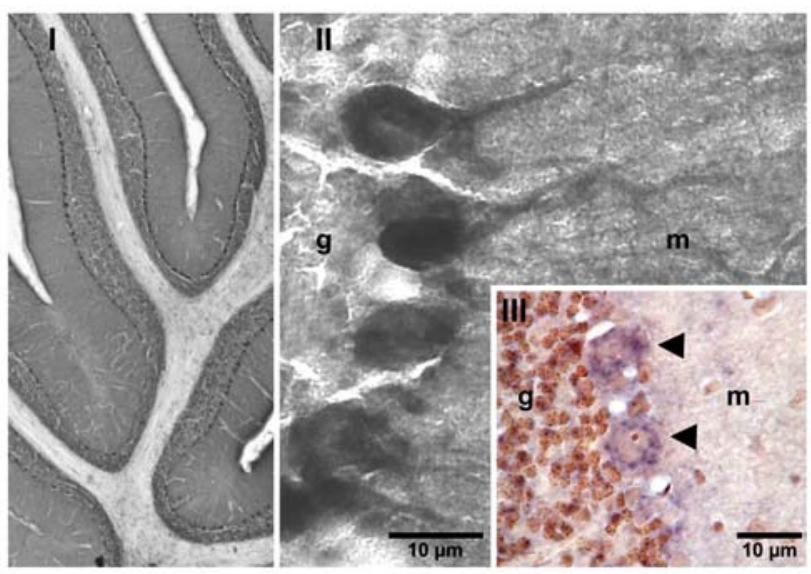

$\mathbf{E}$

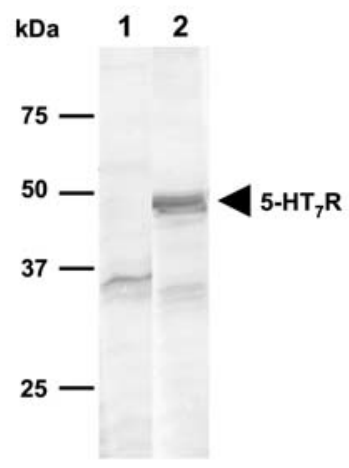

Figure 23. Verification of the polyclonal peptide-specific anti-5-HT $\mathrm{R}$ antibody:

(A) FACS analysis: (a) rat basophilic leucocyte wild-type cells (RBL-wt) [blue line] were stained with the polyclonal anti-5- $\mathrm{HT}_{7} \mathrm{R}$ antibody followed by a secondary Cy2-conjugated anti-rabbit antibody. The RBL-wt cells showed a fluorescence signal ([blue line] shift to the right). As a control, the RBL-wt cells which had been stained only with the secondary antibody [black line] did not show a signal (b) as well as RBL-wt cells which had not been permeabilised [blue line].

(B) RT-PCR analysis of RBL-wt cells: RBL-wt cells showed a specific 5-HT 7 receptor amplicon of $385 \mathrm{bp}$. Samples without reverse transcriptase served as negative control (-). The 'housekeeping gene` $\beta$-actin was used as an internal standard (amplicon size $769 \mathrm{bp}$ ). All RT-PCR products were partially sequenced for their identification. 
(C) immunocytochemistry: the receptor labelling using the anti-5- $\mathrm{HT}_{7} \mathrm{R}$ antibody followed by a secondary Cy2-conjugated anti-rabbit antibody (green colour) indicated a receptor expression on protein level in RBL-wt cells.

(D) immunohistochemistry and in-situ-hybridisation: (I) rat cerebellum (overview); (II) the Purkinje cells of the cerebellum revealed a strong $5-\mathrm{HT}_{7}$ receptor immunoreactivity (IR) which was in line with the detection of the $5-\mathrm{HT}_{7} \mathrm{R}-\mathrm{mRNA}$ in these cells using in-situ-hybridisation. (III) shows the $5-\mathrm{HT}_{7} \mathrm{R}-$ mRNA expression (blue colour) in the Purkinje cells (black arrowheads) [granular layer (g), molecular layer $(\mathrm{m})]$.

(E) immunoblot analysis: one hundred microgram protein of the membrane fraction (Triton X-114 lysate) of Sf.9 cells derived from Spodoptera frugiperda (lane 1) or $100 \mu \mathrm{g}$ protein of the membrane fraction of Sf.9 cells which had been transiently transfected with the murine $5-\mathrm{HT}_{7}$ receptor (lane 2) was separated using a $12 \%$ SDS-PAG. The specific signal of about $48 \mathrm{kDa}$ was detectable in the transfected Sf.9 cells (lane 2), whereas the non-transfected Sf.9 wild-type cells did not show a specific signal (lane 1).

\subsection{Anti-serotonin 2B receptor antibody}

The specificity of the monospecific anti-5- $\mathrm{HT}_{2 \mathrm{~B}}$ receptor antibody was tested by immunohistochemistry and an ELISA with solid phase-coated antigen (see 3.1.3.). Duxon et al. (1997) described the $5-\mathrm{HT}_{2 \mathrm{~B}} \mathrm{R}$ expression in neurones of the rat cortex. Thus, this region and the hypoglossal nucleus (XII) were selected for immunohistochemistry to test for specificity [cortex: fig. 24A or hypoglossal nucleus (XII): fig. 24B]. The anti-5- $\mathrm{HT}_{2 \mathrm{~B}} \mathrm{R}$ antibody immunoreactivity in neurones of both regions was blocked after pre-incubation of the primary antibody with a 50-fold molar excess of the peptide CAISLDRYIAIKKPIQ which had been used for the immunisation. Furthermore, RT-PCR analysis using specific primer pairs for the rat $5-\mathrm{HT}_{2 \mathrm{~B}} \mathrm{R}$ indicated the $5-\mathrm{HT}_{2 \mathrm{~B}} \mathrm{R}$-specific mRNA expression of the receptor in cells within both regions (fig. 24C).

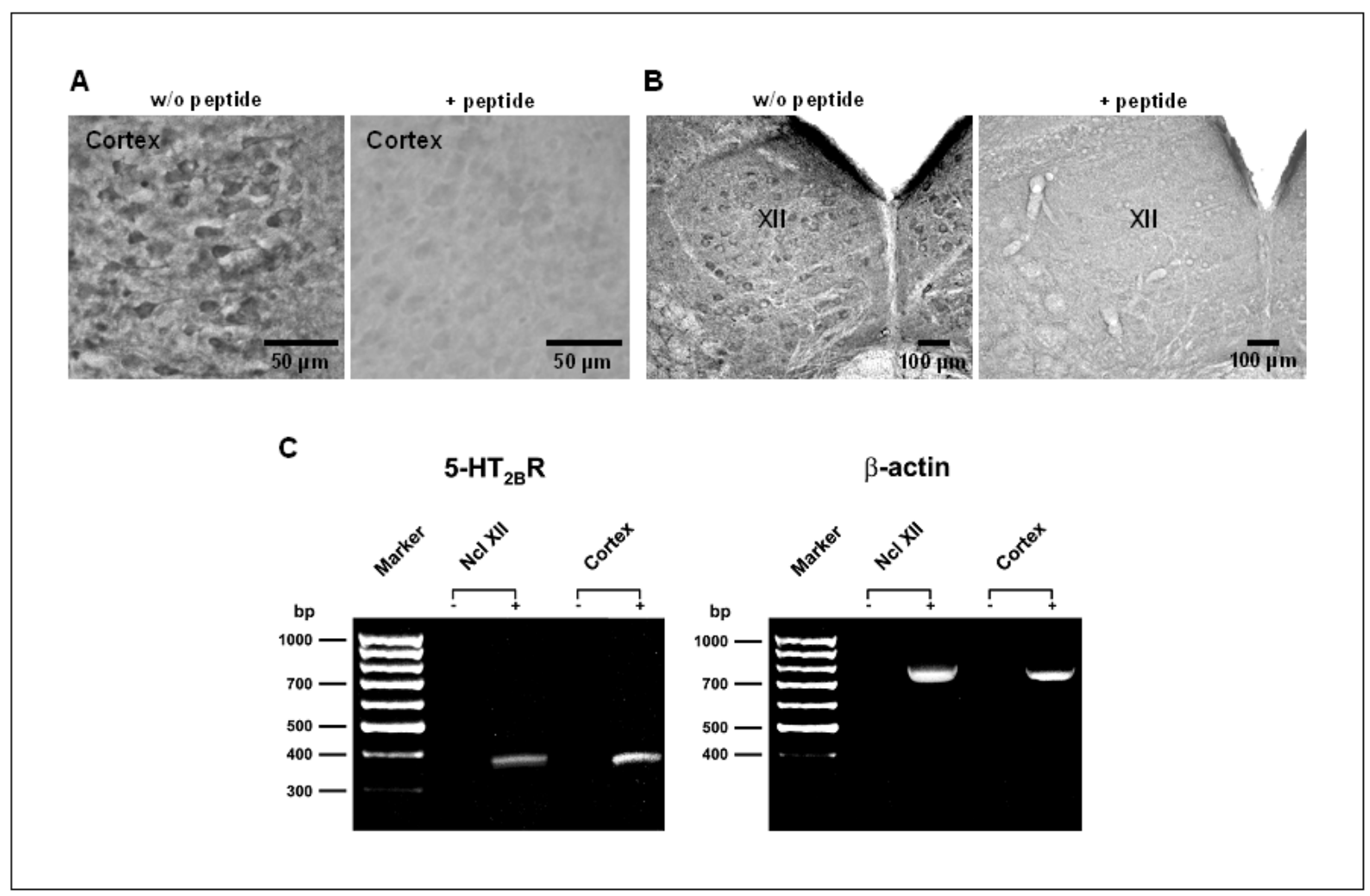

Figure 24. Test of the specificity of the peptide-specific anti-5- $\mathrm{HT}_{2 \mathrm{~B}} \mathrm{R}$ antibody:

(A) and (B) immunohistochemistry: both the pyramidal neurones of the cortex (A) and the motoneurones of the hypoglossal nucleus (XII) (B) revealed a strong $5-\mathrm{HT}_{2 \mathrm{~B}}$ receptor immunoreactivity 
(IR) which was blocked after pre-incubation of the antibody with a 50-fold molar excess of the peptide CAISLDRYIAIKKPIQ (+ peptide) which had been used for the immunisation. The immunostainings were performed using the PAP-method with DAB as chromogen.

(C) RT-PCR analysis of the rat cortex and hypoglossal nucleus: on the left side: the 5- $\mathrm{HT}_{2 \mathrm{~B}} \mathrm{R}-$ specific mRNA was detectable in neurones within both the rat cortex and the hypoglossal nucleus (XII) [amplicon size $380 \mathrm{bp}$ ]. Samples without reverse transcriptase served as negative controls (-). On the right side: the 'housekeeping gene` $\beta$-actin was used as an internal standard. All RT-PCR products were partially sequenced for their identification.

\subsubsection{Production and characterisation of monoclonal anti-serotonin 7 receptor isoform antibodies}

The monoclonal anti-5- $\mathrm{HT}_{7}$ receptor antibodies from Syrian hamster were generated in collaboration with Dr. Demberg and Dr. Schlaf (department of immunology, university of Göttingen).

\subsubsection{Determination of the antibody titre of immunised BALB/c-mice and Syrian hamsters}

Five BALB/c-mice and five Syrian hamsters were immunised with the KLH-conjugated peptide $\mathrm{NH}_{2}$-FPRVQPESVISLNG-COOH derived from the third intracellular loop of the rat $5-\mathrm{HT}_{7} \mathrm{R}$ which was also used for the production of the polyclonal anti$5-\mathrm{HT}_{7} \mathrm{R}$ antibodies (3.1.1.4.2.). The antibody titre of the polyclonal antisera from BALB/c-mice and Syrian hamsters was determined after the third and fifth immunisation using an ELISA with solid phase-coated peptide (see 2.2.1.4.). As there was no development of the antibody titre of more than $1: 1,000$ after the third antigen injection, the BALB/c-mice were not used for further immunisations. Contrary to the BALB/c-mice, the Syrian hamsters were completely hyperimmunised. In particular, the Syrian hamster No.5 developed an antibody titre of more than $1: 1,024,000$ after the fifth immunisation and was then selected for the fusion procedure (see 2.2.1.7. 1.).

Table 5. Antibody titre determination of the antisera from BALB/c-mice and Syrian hamsters: the first blood sample was taken before any immunisation and served as reference. The second (third) blood sample was taken after the third (fifth) immunisation.

\begin{tabular}{|c|c|c|c|}
\hline Species & Antigen & Antib & dy titre \\
\hline BALB/c-mouse & \multirow{12}{*}{$\begin{array}{l}\text { FPRVQPESVISLNG } \\
\text { (Rat 5-HT } 1 \text { R) }\end{array}$} & after the $3^{\text {rd }}$ immunisation & after the $5^{\text {th }}$ immunisation \\
\hline 1 & & \multirow{5}{*}{$>1: 1,000$} & \multirow{5}{*}{ not performed } \\
\hline 2 & & & \\
\hline 3 & & & \\
\hline 4 & & & \\
\hline 5 & & & \\
\hline Syrian hamster & & after the $3^{\text {rd }}$ immunisation & after the $5^{\text {th }}$ immunisation \\
\hline 1 & & $1: 16,000$ & $1: 128,000$ \\
\hline 2 & & $1: 32,000$ & $1: 512,000$ \\
\hline 3 & & $1: 8,000$ & $1: 32,000$ \\
\hline 4 & & $1: 4,000$ & $1: 32,000$ \\
\hline 5 & & $1: 128,000$ & $\leq 1: 1,024,000$ \\
\hline
\end{tabular}




\subsubsection{Isotype-characterisation of the Syrian hamster monoclonal antibodies 5HT7R/18 and 5HT7R/220}

The isotype of the Syrian hamster monoclonal antibodies 5HT7R/18 and 5HT7R/220 was determined using a sandwich ELISA procedure (see 2.2.1.8.). Isotype-specific antibodies derived from mouse which were directed against Syrian hamster IgG- or IgM-molecules (immunoglobulin class) or Syrian hamster $\kappa$ - or $\lambda$-light chains were utilised for the characterisation. The antibodies of the hybridoma cell line clones $5 \mathrm{HT7R} / 18$ and 5HT7R/220 were classified as immunoglobulin molecules of the IgGtype in which the light chains were of the $\lambda$-type (table 6).

Table 6. Isotype-characterisation of the monoclonal antibodies $5 \mathrm{HT7R} / 18$ and $5 \mathrm{HTTR} / 220$

\begin{tabular}{|c|c|c|}
\hline Isotype-specific mouse-mAb & 5HT7R/18 & 5HT7R/220 \\
\hline anti-Syrian hamster IgM antibodies & - & - \\
\hline anti-Syrian hamster IgG antibodies & + & + \\
\hline anti-Syrian hamster $\kappa$-light chain antibodies & - & - \\
\hline anti-Syrian hamster $\lambda$-light chain antibodies & + & + \\
\hline
\end{tabular}

\subsubsection{Purification of the monoclonal $5 \mathrm{HT} 7 \mathrm{R} / 18$ and $5 \mathrm{HTTR} / 220$ antibodies from Syrian hamster hetero-hybridoma supernatants}

The diluted and filtered hetero-hybridoma supernatants of the cell line clones $5 \mathrm{HT7R} / 18$ and 5HT7R/220 from Syrian hamster were purified by affinity chromatography on protein A-sepharose using the 'high-salt' method (see 2.2.1.5.). The purity of the separated peptide-specific monoclonal IgG molecules was shown by Coomassie blue staining of the gel in which only the heavy (55 kDa) and light chains (29 kDa) of the IgG molecule were stained. In contrast to the light chains of the IgG molecule from rabbit $(25 \mathrm{kDa})$, the relative molecular mass of the Syrian hamster light chains was increased (about $29 \mathrm{kDa}$ ).

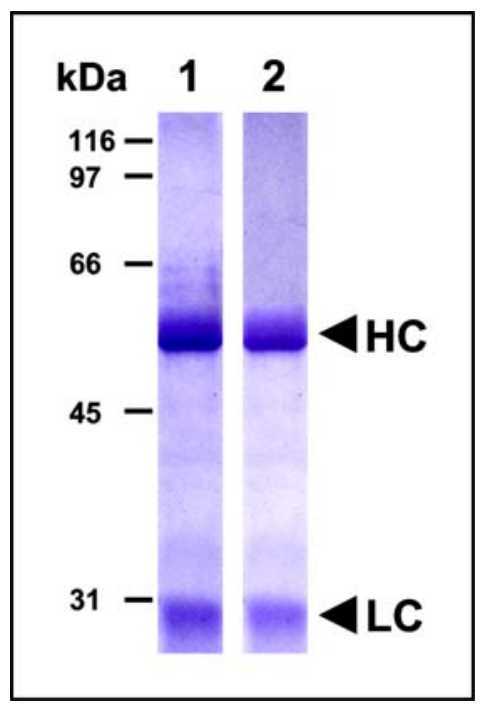

Figure 25. Coomassie blue staining of the SDS-PAG which contains the separated monoclonal IgG molecules: ten microgram of the monoclonal 5HT7R/220 antibodies (lane 1) or $10 \mu \mathrm{g}$ of the monoclonal 5HT7R/18 antibodies (lane 2) was separated under reducing conditions. Only the heavy chains (HC $55 \mathrm{kDa}$ ) and light chains (LC $29 \mathrm{kDa}$ ) were visible. 


\subsubsection{Characterisation of the monoclonal antibodies (clone $5 \mathrm{HT} 7 \mathrm{R} / 220$ )}

In contrast to the cell line clone $5 \mathrm{HT7R} / 18$ antibodies which did not show a signal in the Western blot technique, the hybridoma cell line clone 5HT7R/220 antibodies revealed a specific signal and were then selected for all further characterisation experiments. The monoclonal antibodies $5 \mathrm{HTTR} / 220$ were tested for specificity using FACS analysis, fluorescence dot blot, conventional and fluorescence immunoblot, immunohisto- /cytochemistry, and the ELISA with solid phase-coated antigen (see 3.1.3.).

The FACS analysis of permeabilised transfected in comparison with non-transfected N1E-115 cells showed an increase in the fluorescence intensity (fig. 26Aa), whereas non-permeabilised N1E-115 cells did not reveal a FACS signal (fig. 26Ab). Consequently, the $5 \mathrm{HTTR} / 220$ antibodies which are directed against an intracellular epitope did not show unspecific cross-reactivities with epitopes on the extracellular surface of the N1E-115 cells.

The permeabilised transfected RBL cells in comparison with non-transfected RBL cells also showed an increase of the fluorescence signal (fig. 26Ac) as had previously been shown by FACS analysis using the polyclonal monospecific anti-5- $\mathrm{HT}_{7} \mathrm{R}$ antibody (see 3.1.1.4.2.).

As a negative control, the rat T-lymphocytoma cells 23B6 which had not expressed the 5-HT7 R-specific mRNA (fig. 26B) were not stained (fig. 26Ad).

The RT-PCR analyses of both the wild-type rat basophilic leucocytes (RBL-wt) and N1E-115 wild-type (N1E-wt) cells indicated the expression of 5-HT 7 R-specific mRNA (fig. 26B) which was in accordance with the receptor detection on protein level in N1E-115 and RBL wild-type cells using the FACS scan and immunocytochemistry. 
A
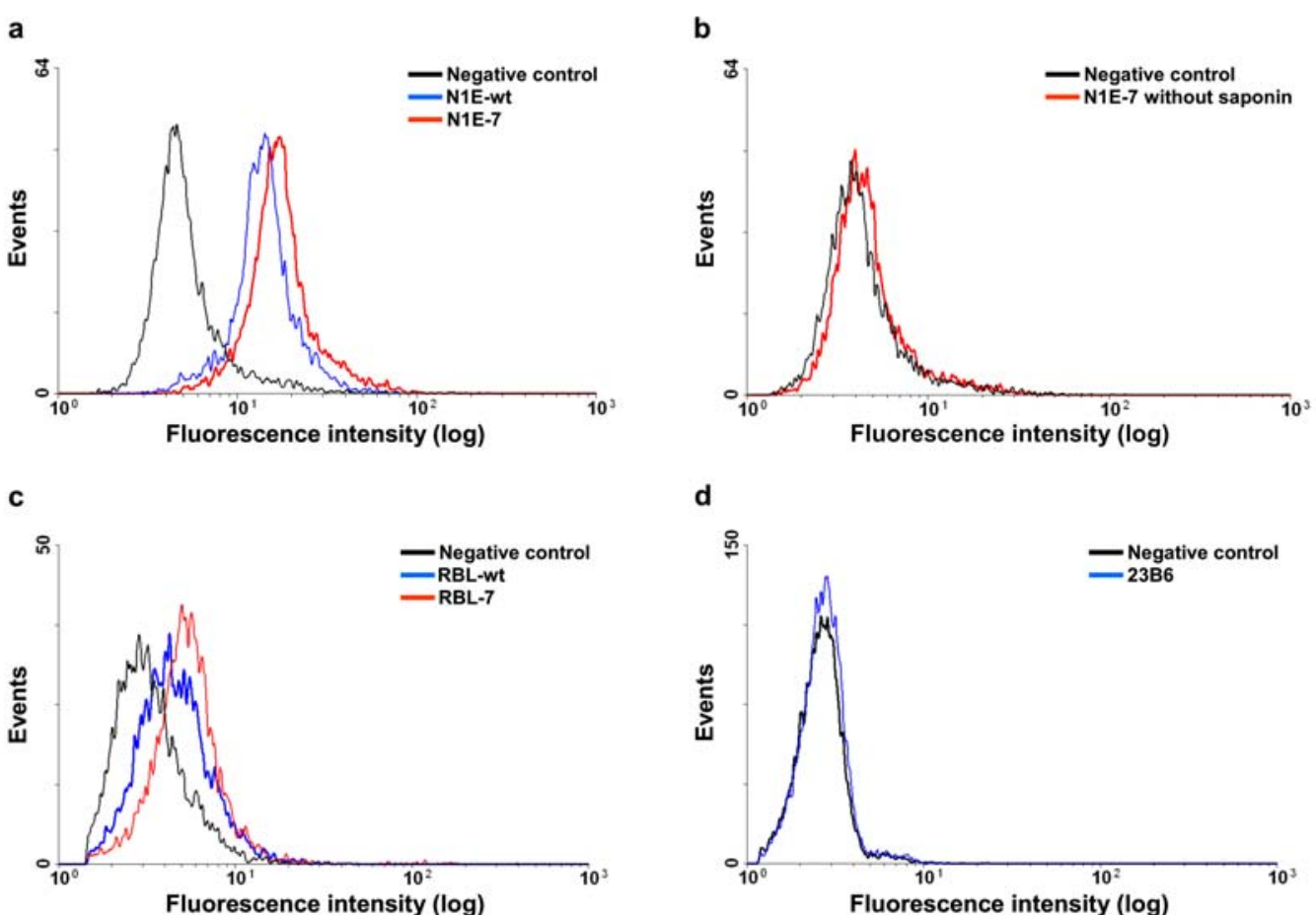

B

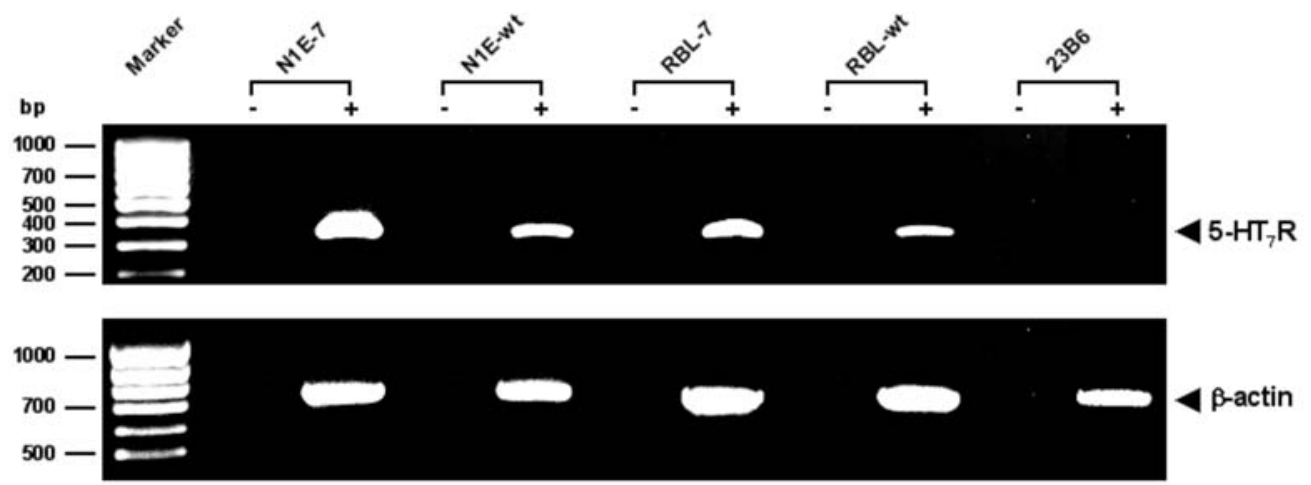

Figure 26. Verification of the monoclonal anti-5-HT 7 R antibody (clone $5 \mathrm{HT} 7 \mathrm{R} / 220$ ):

(A) FACS analysis:

(a) N1E-115 wild-type cells (N1E-wt) [blue line] or N1E-115 cells which had been transiently transfected with the murine $5-\mathrm{HT}_{7}$ receptor (N1E-7) [red line] were stained with the monoclonal antibody 5 HT7R/220 and a secondary TRITC-conjugated anti-Syrian hamster antibody. Both showed a fluorescence signal (shift to the right) [blue and red lines] with an increased intensity of the transfected N1E-115 cells [red line]. As a control, the N1E-7 cells which had been stained only with the secondary antibody [black line] did not show an increased fluorescence intensity.

(b) N1E-7 cells which had not been permeabilised [red line] did not show an increased fluorescence intensity due to the fact that the monoclonal antibody was directed against an intracellular epitope.

(c) rat basophilic leucocyte wild-type cells (RBL-wt) [blue line] or RBL-wt cells which had been transiently transfected with the murine $5-\mathrm{HT}_{7}$ receptor (RBL-7) [red line] were also stained with the monoclonal antibody 5HT7R/220 followed by a secondary TRITC-conjugated anti-Syrian hamster antibody. Both showed a signal (shift to the right) with an increased intensity of the transfected RBL cells. As a control, the RBL cells which had been stained only with the secondary antibody [black line] did not show a signal. 
(d) the rat T-lymphocytoma cells 23B6 which had not expressed the 5- $\mathrm{HT}_{7} \mathrm{R}$-specific mRNA were used as negative controls. The cells were stained with the monoclonal antibody 5HT7R/220 followed by a secondary TRITC-conjugated anti-Syrian hamster antibody [blue line]. 23B6 cells which had been stained only with the secondary antibody [black line] served as a control. Both did not show an increased fluorescence intensity which was in accordance with the RT-PCR analysis.

(B) RT-PCR analysis of transfected and non-transfected cells: N1E-7 or RBL-7 cells showed an increased intensity of the specific amplicon (385 bp) in comparison with non-transfected N1E-wt or RBL-wt cells of which the intensity of the specific amplification product was lower. The $23 B 6$ cells did not show a specific amplification product indicating the absence of 5- $\mathrm{HT}_{7} \mathrm{R}$-specific mRNA expression which was in line with the FACS analysis (fig. 26Ad). Samples without reverse transcriptase served as negative controls (-). The 'housekeeping gene` $\beta$-actin was used as an internal standard (amplicon size 769 bp). All RT-PCR products were partially sequenced for their identification.

Further characterisation experiments indicated that the hybridoma cell line clone 5 HT7R/220 antibodies recognise a single band of about $48 \mathrm{kDa}$ (fig. 27B and C) which corresponds with both the predicted molecular mass of the murine $5-\mathrm{HT}_{7}$ receptor and the relative molecular mass obtained with the polyclonal monospecific anti-5- $\mathrm{HT}_{7}$ receptor antibody from rabbit. The specific signal on the NC-membrane revealed a weaker intensity in the protein derived from the mouse neuroblastoma (N1E-115) wild-type cells and an increased intensity in the protein derived from the transfected cells (fig. 27B) as had previously been shown by FACS analysis (fig. $26 \mathrm{Aa}$ ). The fluorescence immunoblot analysis confirmed the specific $5 \mathrm{HT} 7 \mathrm{R} / 220$ antibody-dependent $5-\mathrm{HT}_{7}$ receptor detection. A single band at about $48 \mathrm{kDa}$ was detectable in the protein derived from transfected and non-transfected N1E-115 cells in which only the transfectants revealed an additional strong signal at about $75 \mathrm{kDa}$ which corresponds with the 5-HT 7 R-YFP (fig. 27C).

The fluorescence dot blot (fig. 27A) was used for the detection of the non-denatured $5-\mathrm{HT}_{7}$ receptor. Both the non-transfected N1E-115 wild-type cells and the $5-\mathrm{HT}_{7} \mathrm{R}-$ YFP-transfected N1E-115 cells revealed a fluorescence signal in which the intensity of the fluorescence signal was stronger for the transfectants.

The 5HT7R/220 antibody-dependent immunoreactivity in N1E-115 cells (fig. 27D) was blocked after pre-incubation of the 5HT7R/220 antibody with a 50-fold stoichiometric excess of the peptide FPRVQPESVISLNG, which had been used for the immunisation, and hence indicated a specific labelling. 
- Results -

A

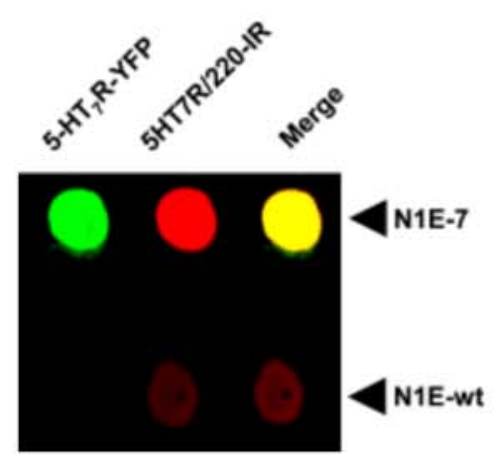

C

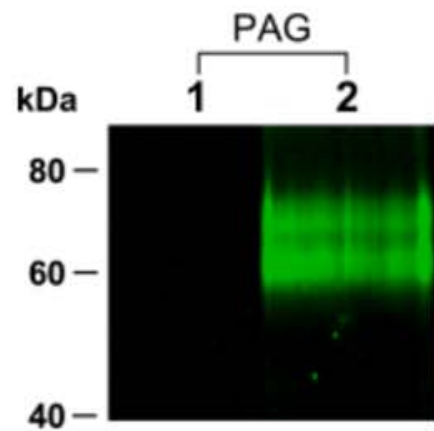

D
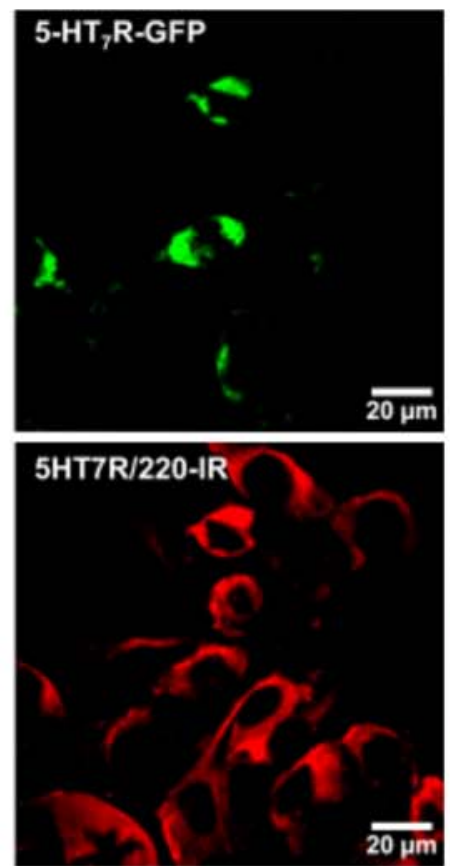

B
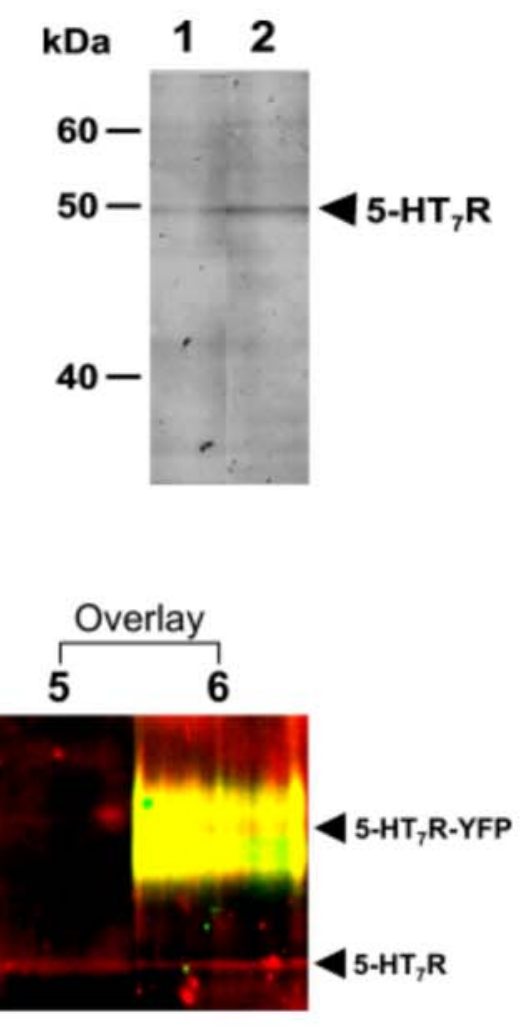
Figure 27. Test of the specificity of the monoclonal anti-5-HT $\mathrm{R}$ antibody (clone $5 \mathrm{HT7R} / 220$ ):

(A) fluorescence dot blot analysis: one hundred and fifty microgram protein (Triton X-114 lysate) of the membrane fraction of N1E-115 cells (N1E-wt) or $150 \mu \mathrm{g}$ protein of the membrane fraction of N1E115 cells which had been transiently transfected with the murine 5-HT $\mathrm{R}$-YFP (N1E-7) [green colour] was dotted onto the membrane and stained with the monoclonal $5 \mathrm{HT} 7 \mathrm{R} / 220$ antibody followed by a secondary Cy5-conjugated anti-Syrian hamster antibody [red colour]. Both the transfected and nontransfected N1E-115 cells revealed a positive fluorescence signal which was in accordance with the FACS and immunoblot analyses.

(B) immunoblot analysis: one hundred and fifty microgram protein (Triton X-114 lysate) of the membrane fraction of N1E-115 cells (lane 1) or $150 \mu \mathrm{g}$ protein of the membrane fraction of N1E-115 cells which had been transiently transfected with the murine $5-\mathrm{HT}_{7}$ receptor (lane 2) was separated using a $12 \%$ SDS-PAG. The specific signal of about $48 \mathrm{kDa}$ showed a weak intensity in the protein derived from the wild-type cells (lane 1) and an increased intensity in the protein derived from the transfected cells (lane 2) which corresponded with the FACS analysis.

(C) fluorescence immunoblot analysis: two hundred microgram protein (Triton X-114 lysate) of the membrane fraction of N1E-115 cells which had been transfected with the murine serotonin 7 receptorYFP (N1E-7) [lane 2 (green colour)] or $200 \mu \mathrm{g}$ protein of the membrane fraction of non-transfected N1E-115 cells (N1E-wt) [lane 1] was separated using a 12\% polyacrylamide gel (PAG) without SDS which was scanned using a fluorescence laser scanner. After the protein transfer, the membrane was applied with the $5 \mathrm{HT} 7 \mathrm{R} / 220$ antibody followed by a Cy5-conjugated anti-Syrian hamster antibody (red colour). A single band at about $48 \mathrm{kDa}$ was detectable in the protein derived from transfected and nontransfected N1E-115 cells. The transfectants revealed an additional strong signal at about $75 \mathrm{kDa}$ which corresponds with the $5-\mathrm{HT}_{7} \mathrm{R}-\mathrm{YFP}$ [overlay of the PAG (green) and the immunoblot (red) resulting in yellow colour].

(D) immunocytochemistry: the receptor staining using the mAb 5HT7R/220 followed by a secondary Cy5-conjugated anti-Syrian hamster antibody (red colour) indicated the receptor expression in both N1E-wt cells and N1E-7 cells (green colour). 


\subsubsection{Test of the antibodies for cross-reactivities using an ELISA with solid phase-coated antigen}

The monospecific polyclonal anti-serotonin 4(a), 7, and 2B receptor antibodies from rabbit and the monoclonal $5 \mathrm{HTTR} / 18$ and $5 \mathrm{HT} 7 \mathrm{R} / 220$ antibodies from Syrian hamster were tested for cross-reactivities using an ELISA with solid phase-coated antigen (see 2.2.1.4.). As is visible in table 7, all of the antibodies did only recognise the peptides which were used for their generation. There were no cross-reactivities of the antibodies with the immobilised glial fibrillary acidic protein, the myelin basic protein, and neurofilaments. The monospecific anti-5- $\mathrm{HT}_{4(\mathrm{a})} \mathrm{R}$ antibody recognised both the murine peptide (HSGHHQELEKLPIHNDP) and the rat peptide (HSGQHQELEKLPIHNDP) in which the amino acid sequences differ only in one position $(\mathrm{H} \rightarrow \mathrm{Q})$.

Table 7. Test of the poly- and monoclonal antibodies for cross-reactivities: one microgram of each antigen was adsorbed to the microtitre plate and incubated with the purified antibodies (10 $\mu \mathrm{g} / \mathrm{ml}$ ). Abbreviations: myelin basic protein (MBP), glial fibrillary acidic protein (GFAP).

\begin{tabular}{|c|c|c|c|c|c|}
\hline \multirow[b]{2}{*}{ Antigen } & \multicolumn{3}{|c|}{ pAb } & \multicolumn{2}{|c|}{ mAb } \\
\hline & 4(a) & 7 & 2B & $5 \mathrm{HT} 7 \mathrm{R} / 18$ & $5 \mathrm{HT} 7 \mathrm{R} / 220$ \\
\hline HSGHHQELEKLPIHNDP [5-HT $4(\mathrm{a}) \mathrm{R}, \mathrm{C}$-term.] & + & - & - & - & - \\
\hline HSGQHQELEKLPIHNDP [5-HT ${ }_{4(\mathrm{a})} \mathrm{R}, \mathrm{C}$-term.] & + & - & - & - & - \\
\hline KHERKNISSFKREQ [5-HT 7 R, $3^{\text {rd }}$ intr. loop] & - & - & - & - & - \\
\hline FPRVQPESVISLNG [5-HT, $\mathrm{R}, 3^{\text {rd }}$ intr. loop] & - & + & - & + & + \\
\hline DRSNPENECTISK [5-HT ${ }_{1 A} R, 2^{\text {nd }}$ extr.loop] & - & - & - & - & - \\
\hline VRQGEDADDATELVIEC [5-HT $1 \mathrm{~A} R, 3^{\text {rd }}$ intr. loop] & - & - & - & - & - \\
\hline AVGTPCANGAVRQG [5-HT $1 \mathrm{~A} R, 3^{\text {rd }}$ intr. loop] & - & - & - & - & - \\
\hline CAISLDRYIAIKKPIQ [5- $\mathrm{HT}_{2 \mathrm{~B}} \mathrm{R}, 2^{\text {nd }}$ intr. loop] & - & - & + & - & - \\
\hline MBP & - & - & - & - & - \\
\hline GFAP & - & - & - & - & - \\
\hline Neurofilaments & - & - & - & - & - \\
\hline
\end{tabular}

Taken together, the monospecific polyclonal anti-serotonin 4(a), 7, and 2B receptor antibodies from rabbit and the monoclonal 5HT7R/18 and 5HT7R/220 antibodies from Syrian hamster were specific for their target antigen. With the exception of the polyclonal anti-5- $\mathrm{HT}_{2 \mathrm{~B}} \mathrm{R}$ antibody and the monoclonal 5HT7R/18 antibody, all other antibodies revealed a specific signal in the Western blot technique. All of the generated antibodies worked well in immunohisto- /cytochemistry, FACS analysis, and the ELISA assay. 
3.2. Expression and function of the serotonin 4(a) receptor isoform in the respiratory system

\subsubsection{Expression of $5-\mathrm{HT}_{4(\mathrm{a})}$ receptors in neurones of the preBötzinger complex}

The characterised polyclonal monospecific anti-5- $\mathrm{HT}_{4(\mathrm{a})}$ receptor isoform antibody from rabbit had been used to specifically identify the spatial expression of the $5-\mathrm{HT}_{4(\mathrm{a})}$ receptor isoform on protein level in rat brainstem slices. The immunohistochemistry indicated that the $5-\mathrm{HT}_{4(\mathrm{a})}$ receptor was expressed in the preBötzinger complex (PBC), a region that is known to control spontaneous breathing movements [Smith et al. (1991)]. Since the co-expression of $\mu$-opioid ( $\mu$-OR) and substance P-reactive neurokinin-1 (NK-1) receptors have been suggested as potential immunocytochemical markers for respiratory neurones [Gray et al. (1999), Gray et al. (2001), Guyenet and Wang (2001)], multiple labelling experiments using these markers in combination with the specific anti-5- $\mathrm{HT}_{4(\mathrm{a})} \mathrm{R}$ antibody were performed in which vagal motoneurones, visualised by choline acetyl transferase (ChAT) staining, had been excluded from the analysis.

Twenty-eight brainstem slices from 5 different animals were analysed for co-immunoreactivities of $\mathrm{NK}-1$ and $5-\mathrm{HT}_{4(\mathrm{a})}$ receptors. Three different types of immunoreactive medullary interneurones were identified: $35.5 \%$ (245 of 691 cells) of immunoreactive interneurones displayed an intense NK-1 and 5- $\mathrm{HT}_{4(\mathrm{a})}$ receptor co-immunoreactivity and $34.1 \%$ (236 of 691 cells) of interneurones revealed a $5-\mathrm{HT}_{4(\mathrm{a})}$ receptor immunoreactivity alone, whereas $30.4 \%$ (210 of 691 cells) of interneurones revealed only a NK-1 receptor immunoreactivity (fig. 28 and 29).

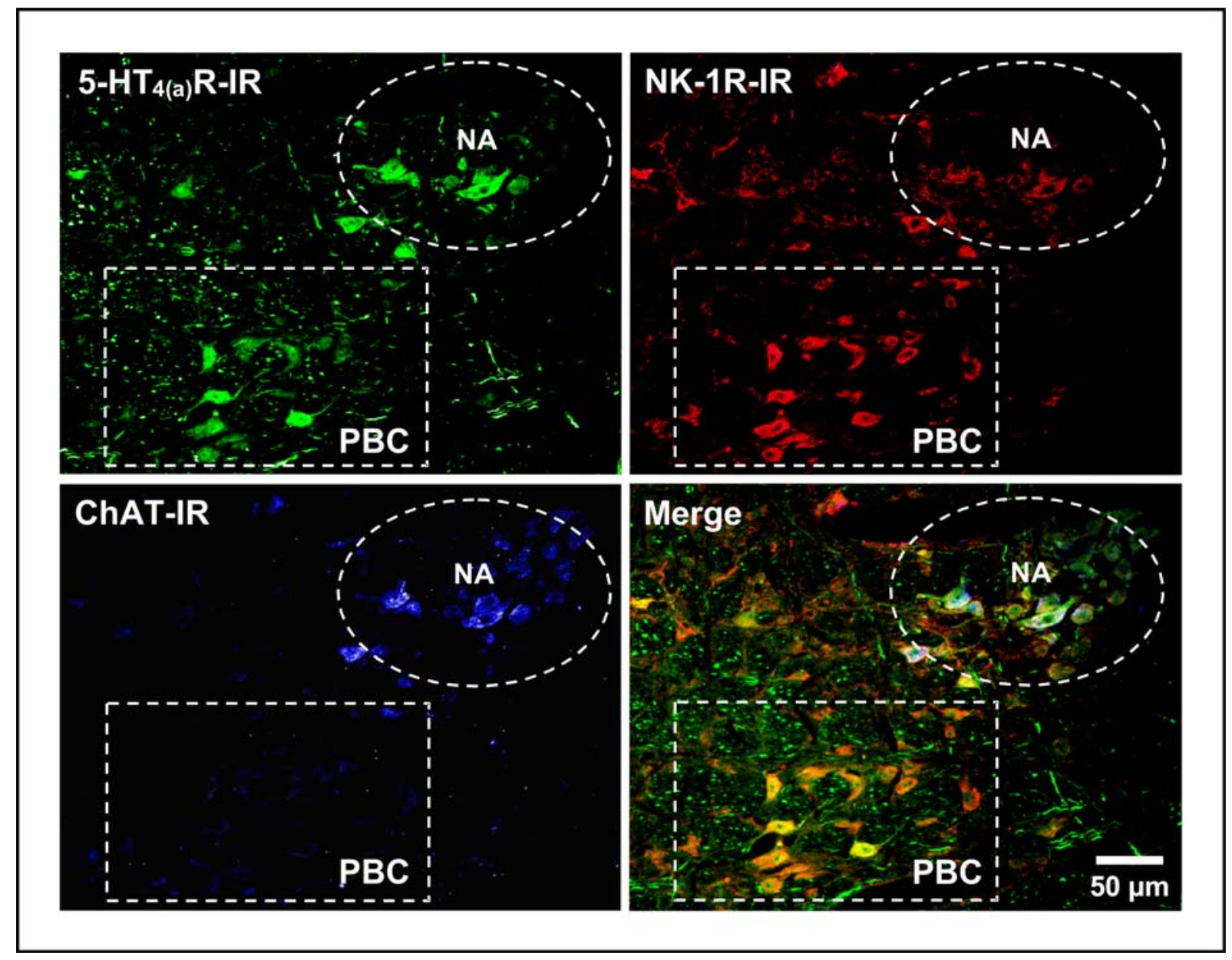


Figure 28. Triple labelling of 5-HT $4(a) R, N K-1 R$, and ChAT in neurones of the preBötzinger complex (PBC): forty-micrometre-thick transversal slices were cut at the level of the PBC and stained with the polyclonal anti-5- $\mathrm{HT}_{4(\mathrm{a})} \mathrm{R}$ antibody from rabbit, the anti-NK-1-R antibody from guinea pig, and the anti-ChAT antibody from goat followed by appropriate secondary fluorochrome-conjugated antibodies $\left[5-\mathrm{HT}_{4(\mathrm{a})} \mathrm{R}\right.$ (Alexa 488, green colour), NK-1R (Alexa 546, red colour), and ChAT (Alexa 647, blue colour)]. Abbreviations: preBötzinger complex (PBC), choline acetyl transferase (ChAT), neuro-kinin-1 receptor (NK-1R), immunoreactivity (IR), nucleus ambiguus (NA), immunoreactivity (IR).

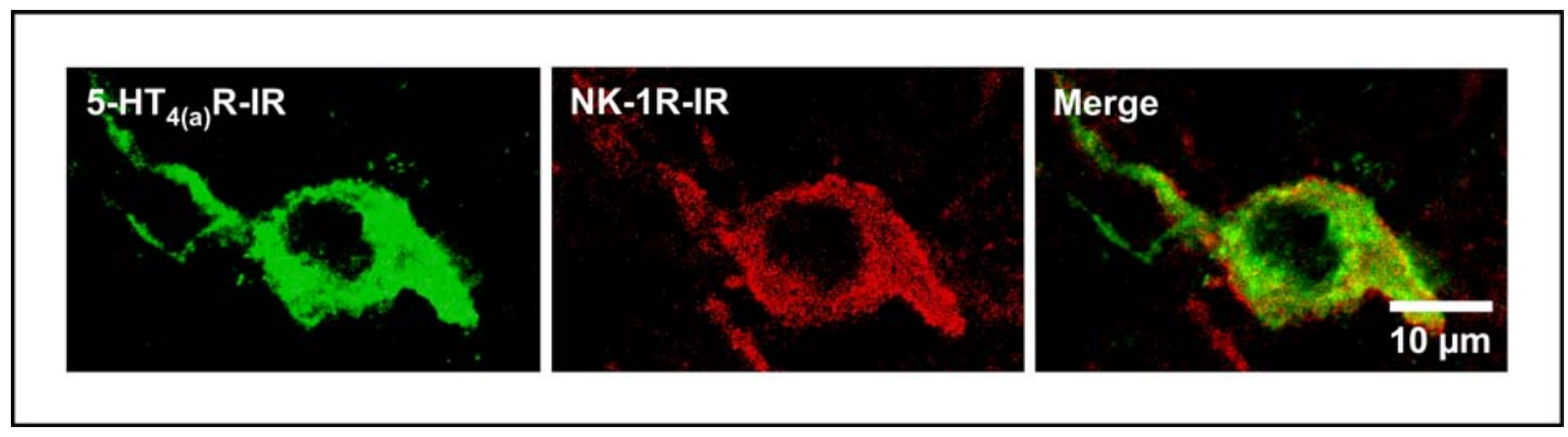

Figure 29. Triple labelling of $5-H_{4} T_{4(a)} R, N K-1 R$, and ChAT in a single neurone: a neurone within the $\mathrm{PBC}$ region expressing $5-\mathrm{HT}_{4(\mathrm{a})}$ (green colour) and $\mathrm{NK}-1$ (red colour) receptors is shown at a higher magnification. The specific immunostaining revealed that the $5-\mathrm{HT}_{4(\mathrm{a})}$ receptors were predominantly expressed in the soma and proximal dendrites of the neurones.

In a similar study, 18 brainstem slices from 3 different animals were analysed for coimmunoreactivities of $\mu$-opioid and $5-\mathrm{HT}_{4(\mathrm{a})}$ receptors within the $\mathrm{PBC}$ region. $\mathrm{A}$ positive staining was found in $46.8 \%$ (386 of 824 cells) of interneurones for both $\mu$ opioid and $5-\mathrm{HT}_{4(\mathrm{a})}$ receptors, whereas a population of $53.2 \%$ (438 of 824 cells) of interneurones exhibited only a $\mu$-opioid receptor immunoreactivity (fig. 30).

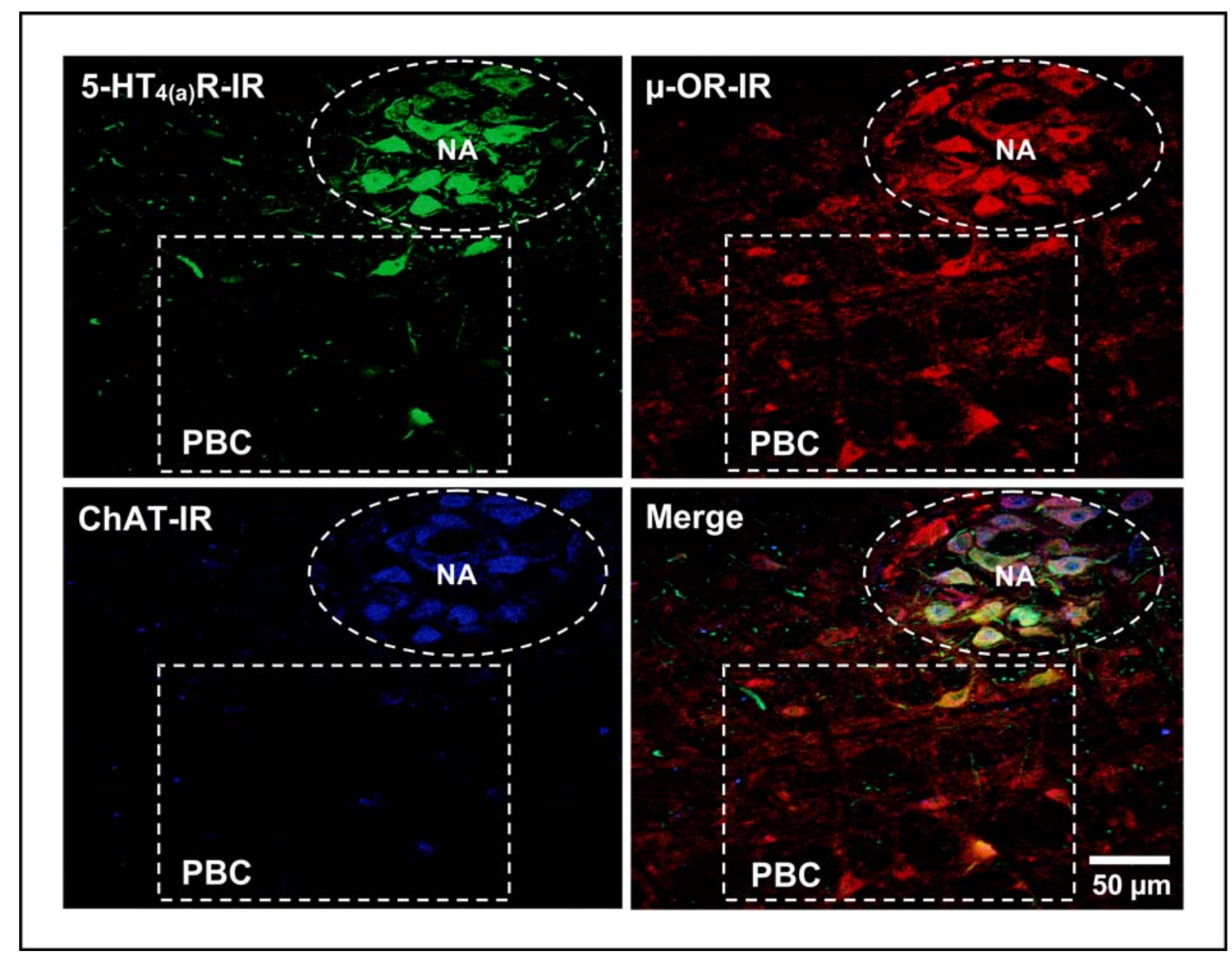


Figure 30. Triple labelling of 5-HT $4(a) R$, $\mu$-opioid receptors ( $\mu$-OR), and ChAT in neurones of the PBC: forty-micrometre-thick transversal slices were cut at the level of the PBC and stained with the polyclonal anti-5- $\mathrm{HT}_{4(\mathrm{a})} \mathrm{R}$ antibody from rabbit, the anti- $\mu-\mathrm{OR}$ antibody from guinea pig, and the antiChAT antibody from goat followed by appropriate secondary fluorochrome-conjugated antibodies [5$\mathrm{HT}_{4(\mathrm{a})} \mathrm{R}$ (Alexa 488, green colour), $\mu$-OR (Alexa 546, red colour), and ChAT (Alexa 647, blue colour)].

These data suggested that approximately one-half of all $5-\mathrm{HT}_{4(\mathrm{a})}$ receptor-positive interneurones within the PBC expressed both the NK-1 and the $5-\mathrm{HT}_{4(\mathrm{a})}$ receptors. This was confirmed by multiple stainings of the $5-\mathrm{HT}_{4(\mathrm{a})}, \mathrm{NK}-1$, and $\mu$-opioid receptors in the same slice (fig. 31).

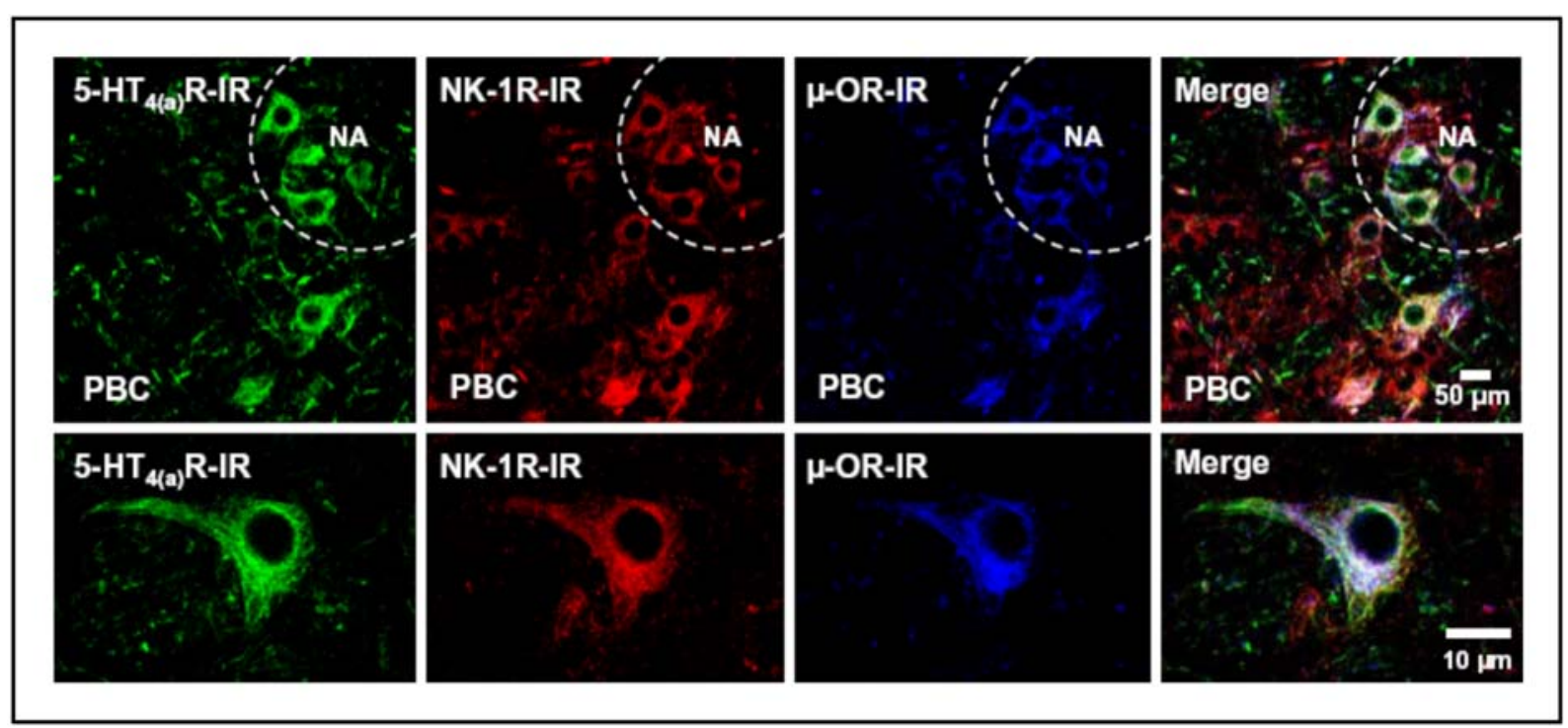

Figure 31. Triple labelling of $5-\mathrm{HT}_{4(a)} \mathrm{R}, \mathrm{NK}-1 \mathrm{R}$, and $\mu-O R$ in neurones of the PBC: on the top: forty-micrometre-thick transversal slices at the level of the PBC were stained with the polyclonal anti-5$\mathrm{HT}_{4(\mathrm{a})} \mathrm{R}$ antibody from rabbit, the anti-NK-1R antibody from guinea pig, and the anti- $\mu$-OR antibody from goat followed by appropriate secondary fluorochrome-conjugated antibodies [5-HT $4(\mathrm{a}) \mathrm{R}$ (Alexa 488, green colour), NK-1R (Alexa 546, red colour), and $\mu-O R$ (Alexa 647, blue colour)]. A single neurone at a higher magnification is shown at the bottom panels demonstrating a strong co-expression of $5-\mathrm{HT}_{4(\mathrm{a})}, \mathrm{NK}-1$, and $\mu$-opioid receptors. 


\subsubsection{Expression of $5-\mathrm{HT}_{4(\mathrm{a})}$ receptors in identified respiratory neurones}

For the verification that the $5-\mathrm{HT}_{4(\mathrm{a})}$ receptor-immunoreactive interneurones were indeed represented by respiratory neurones, single-cell RT-PCR analyses in collaboration with Dr. Haller and Dr. Ponimaskin (department of neurophysiology, university of Göttingen) were performed on the cytosol which had been harvested from identified inspiratory neurones in the rhythmically active slice preparation (see 2.2.6.1.1.).

95.2\% (20 of 21 cells from 21 different slice preparations) identified neurones which had been analysed using the set of primers, which was common for all known splice variants of the $5-\mathrm{HT}_{4}$ receptor, expressed the $5-\mathrm{HT}_{4}$ receptor-specific mRNA (fig. 32B). In view of the large number of $5-\mathrm{HT}_{4}$ receptor isoforms, the mRNA expression of different $5-\mathrm{HT}_{4}$ receptor splice variants were investigated.

RT-PCR analysis of the PBC region and of individual respiratory neurones proved the expression of the $5-\mathrm{HT}_{4(\mathrm{a})}$ and $5-\mathrm{HT}_{4(\mathrm{~b})}$ receptor-specific mRNAs, but not of the 5$\mathrm{HT}_{4(\mathrm{e})}$ receptor-specific mRNA, in the PBC region, whereas electrophysiologically defined inspiratory neurones expressed only the 5- $\mathrm{HT}_{4(\mathrm{a})} \mathrm{R}$-specific mRNA (fig. 32B). Immunocytochemical studies confirmed these observations, demonstrating a strong $5-\mathrm{HT}_{4(\mathrm{a})}$ receptor immunoreactivity (fig. $32 \mathrm{C}$ ) in $88.9 \%$ of biocytin-labelled inspiratory neurones (16 of 18 cells from 18 different slice preparations).

The expression profile for the NK-1 receptor-specific mRNA as well as for the $\mu$ opioid receptor-specific mRNA was also determined by single-cell RT-PCR. The expression of the NK-1 receptor mRNA was found in only $30.7 \%$ (4 of 13 cells from 13 different slice preparations) of defined inspiratory neurones, whereas immunohistochemical data from the PBC region indicated the NK-1 receptor expression on protein level in $65.9 \%$ of the neurones within the PBC as had previously been shown. This difference revealed the presence of non-respiratory neurones which do also express the NK-1 receptor [Li and Guyenet (1997)]. In contrast, the $\mu$-opioid receptorspecific mRNA was detected in all inspiratory neurones which had been analysed (16 of 16 cells from 16 different slice preparations). 
A

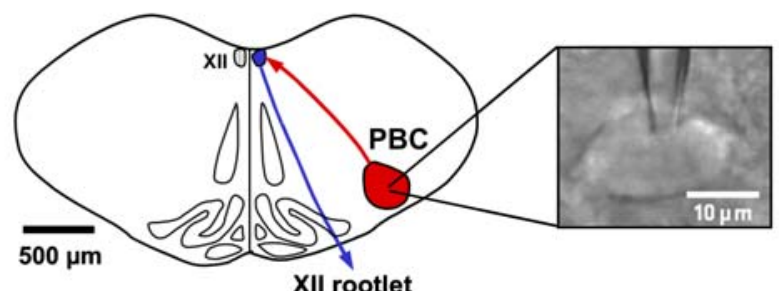

XII rootlet

B
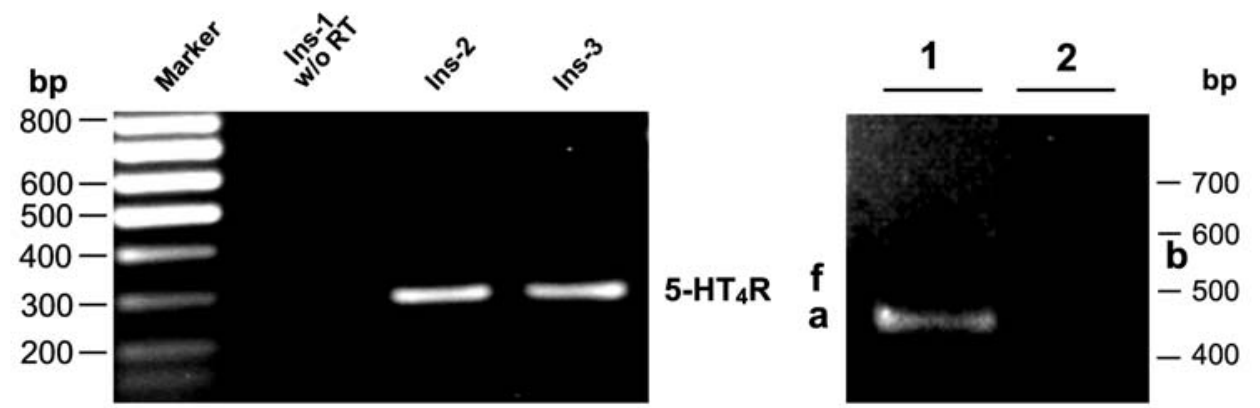

C
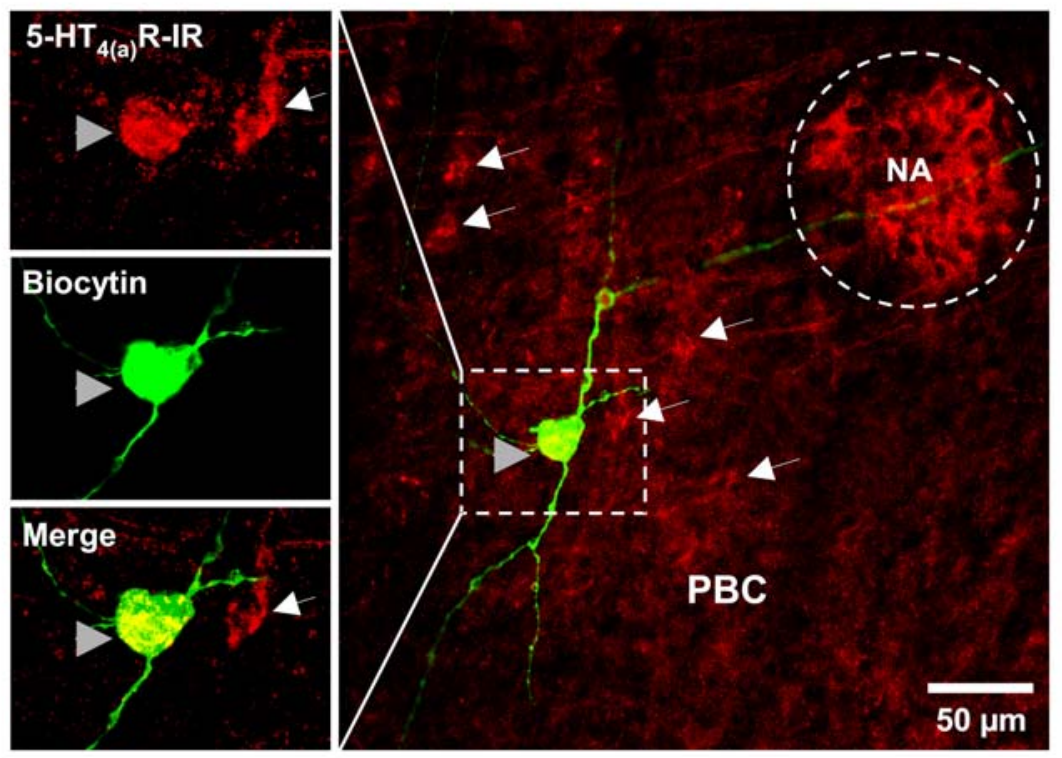

Figure 32. Expression of $5-\mathrm{HT}_{4}$ receptors in identified respiratory neurones: $(A)$ the site of electrophysiological recordings (left) with an inspiratory neurone on the tip of the patch pipette is shown. Traces (right): the integrated hypoglossal nerve $\left(\mathrm{XII}_{\mathrm{a}}\right)$ activity (on the top) corresponded with the rhythmic inward currents [membrane current $\left(I_{m}\right)$ ] in a single inspiratory neurone when recorded in the whole-cell configuration (at the bottom panel). (B) Left: single-cell RT-PCR analysis of inspiratory neurones. The gel electrophoresis was carried out for RT-PCR products which had been amplified with specific 5- $\mathrm{HT}_{4}$ primers. The control reaction without reverse transcription (w/o RT) is shown in the first line [inspiratory neurone (Ins), base pairs (bp)]. Right: RT-PCR analysis of $5-\mathrm{HT}_{4}$ receptor splice variants in an individual inspiratory neurone. Lane 1 shows primers amplifying the (a), (e), and (f ) isoforms, whereas lane 2 shows primers amplifying the (b) isoform. All RT-PCR products were partially sequenced for their identification. (C) Example of an inspiratory PBC neurone which had been labelled intracellularly with biocytin (grey arrowhead) exhibited a strong 5-HT $4(\mathbf{a}) \mathrm{R}-\mathrm{IR}$ (Alexa 546, red colour). This neurone was surrounded by $5-\mathrm{HT}_{4(\mathrm{a})} \mathrm{R}$-ir somatic profiles (white arrowheads) within the PBC. 


\subsubsection{Compensation of the fentanyl-induced depression of the respiratory activity by selective activation of the $5-\mathrm{HT}_{4(\text { a) }}$ receptor using BIMU-8}

The $5-\mathrm{HT}_{4(\mathrm{a})}$ and $\mu$-opioid receptors regulate antagonistically the intracellular cyclic adenosine $5^{\prime}, 3^{\prime}$-monophosphate concentration $\left([\mathrm{CAMP}]_{\mathrm{i}}\right)$. An increase of the [CAMP $]_{i}$ leads to an acceleration of the respiratory activity [Ballanyi et al. (1997)]. Due to the fact that the $5-\mathrm{HT}_{4(\mathrm{a})}$ receptor, which increases the $[\mathrm{cAMP}]_{\mathrm{i}}$, and the $\mu$-opioid receptor, which decreases the [CAMP], were strongly co-expressed in the preBötzinger complex (PBC), as had previously been shown, it was investigated in collaboration with Dr. Dutschmann (department of neurophysiology, university of Göttingen) whether the application of the 5- $\mathrm{HT}_{4(\mathrm{a})}$ receptor agonist BIMU-8 compensates the depression of the respiratory activity caused by application of the $\mu$-opioid receptor agonist fentanyl using a fully intact animal model (see 2.2.6.2.). Sprague Dawley rats of either sex $(250-350 \mathrm{~g})$ were anaesthetised by intraperitoneal injection of pentobarbital $(60 \mathrm{mg} / \mathrm{kg})$ in which the appropriate anaesthesia was tested by repeatedly pinching the forepaw. In case of complex reflex responses, an additional amount of pentobarbital was applied (1/10 of the initial doseage). The femoral vein and the trachea were canulated for drug application or measurement of the respiratory airflow (inspiration/expiration) using a MacLab-linked pressure transducer which was connected to the tracheal tubing. The respiratory minute volume $(\mathrm{RMV}=$ tidal volume $\mathrm{x}$ respiratory rate $[\mathrm{ml} / \mathrm{min}])$ was used as a parameter for the respiratory activity. The systemic application of BIMU-8 $(1-2 \mathrm{mg} / \mathrm{kg})$ significantly increased the respiratory minute volume (RMV) by $52.9 \pm 10.4 \%(p<0.05, n=3)$ of the controls. The application of the 5- $\mathrm{HT}_{4(\mathrm{a})}$ receptor antagonist GR 113808 (3- 4 $\mathrm{mg} / \mathrm{kg}$ ) prior to the BIMU-8 application did not significantly change the resting RMV ($8.4 \pm 5 \%$ ), but diminished the BIMU-8 evoked increase of RMV to $12.4 \pm 10.9 \%$ ( $p<$ $0.05, \mathrm{n}=3$ ). The antagonist GR 113808 , which is specific for the $5-\mathrm{HT}_{4(\mathrm{a})}$ receptor, blocked the stimulating effect of the agonist BIMU-8 which demonstrated that this effect was indeed due to a specific $5-\mathrm{HT}_{4(\mathrm{a})}$ receptor activation. The application of fentanyl $(10-15 \mu \mathrm{g} / \mathrm{kg})$ induced a significant reduction of the RMV to $3.9 \pm 8.5 \%$ of the control $(p<0.001, n=5)$. A transient manual ventilation was necessary to rescue the animal during the fentanyl treatment. The subsequent application of BIMU-8 (1 $2 \mathrm{mg} / \mathrm{kg}$ ) prevailed over the effect of fentanyl and restored a stable breathing in which the RMV recovered to $70.6 \pm 18.1 \%$ of the control $(p<0.001, n=5)$ within 3 min. The additional application of naloxone further increased the RMV above control levels to $149.7 \pm 14.3 \%(p<0.001, n=4)$ (fig. 35).

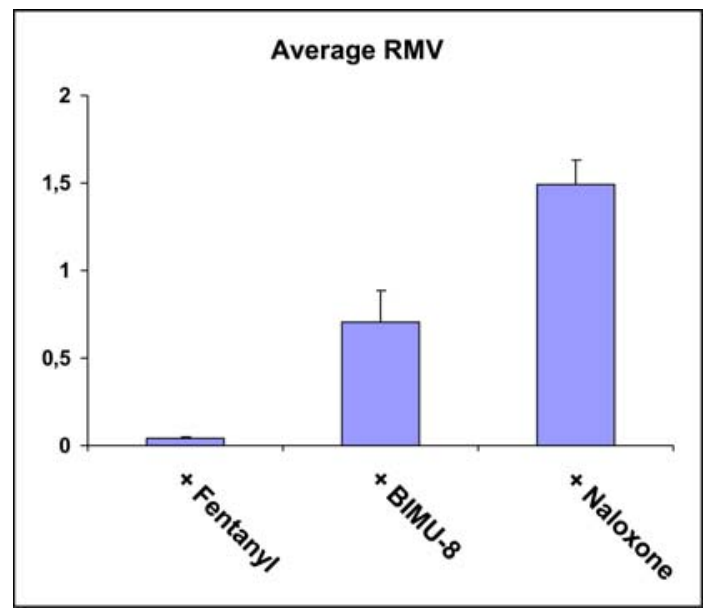

Figure 33. The histogram indicates the significant recovery of the fentanyl-induced decrease of the respiratory minute volume (RMV) caused by BIMU-8 and the further increase of the RMV after the application of naloxone. 
To investigate the drug effects on nociception, tail-flick response (TFR) tests (see 2.2.6.2.) were performed. The TFR test was described for the first time by D'Amour and Smith (1941). The expression of the TFR has been shown to be modulated by the administration of neurohormonal agents or opioid drugs, or through activation of descending pathways from the brain to the spinal cord [Akil and Liebeskind (1975), Akil and Mayer (1972), Yaksh and Wilson (1979)]. When radiant heat is directed to the tail of a rat, a stable, spinally mediated nociceptive response occurs in the form of a flicking or jerking of the tail away from the heat source [Williams and Thorn (1984)]. Differences between the experimental and baseline latencies are interpreted as an index of analgesia. Increases in the latency for the rat to flick its tail are indicative of analgesia, while decreases in tail-flick latency are indicative of hyperalgesia.

High intensity light was applied to marked tail spots $(1 \mathrm{~cm}$ from the tip, 4 spots at an interval of $1 \mathrm{~cm}$ ), in which the anti-nociceptive TFR is most likely to be produced independently from changes in either tail-skin temperature or core temperature [Lichtman et al. (1993)]. The tail-flick (TF) was quantified by electronical measurement of the latency from 'heat on to the evoked withdrawal response. The average TFR latency values of 3 consecutive trails before drug application were used as baseline. To avoid severe tissue damage, the heat stimulus was stopped when the TFR latency was exceeding $300 \%$ of the baseline. This was defined as a complete TFR abolishment.

Under control conditions (60 $\mu \mathrm{g} / \mathrm{kg}$ pentobarbital), the latency of the TFR ranged from 4 - $7 \mathrm{~s}$. Fentanyl $(10-15 \mu \mathrm{g} / \mathrm{kg})$ induced a complete abolishment of the TFR $(\mathrm{p}<$ $0.001, n=5)$. The abolishment of the TFR was fully maintained after BIMU-8 application within a maximal stimulation period of $20 \mathrm{~s}$ meaning that the TFR latency was $300 \%$ of the baseline $(p<0.001, n=5)$. The additional systemic application of naloxone $(1 \mathrm{mg} / \mathrm{kg})$ re-established the TFR immediately and induced even a decrease in latency below controls $(-16.5 \pm 15.5 \%, n=5)$ (fig. 35).

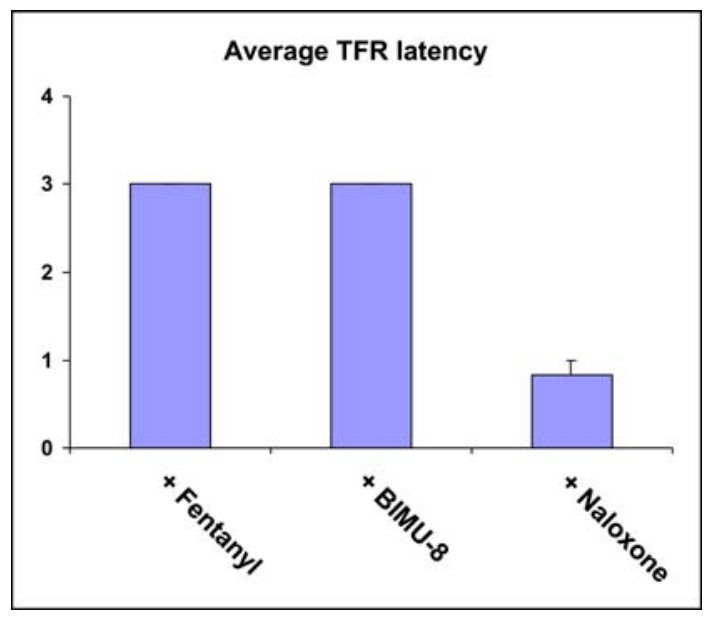

Figure 34. The histogram shows the abolishment of the tail-flick response (TFR) which was defined as $300 \%$ of the baseline $(3=$ tail-flick abolishment). After the application of naloxone, the TFR was reestablished. 
A

BIMU-8

Naloxone

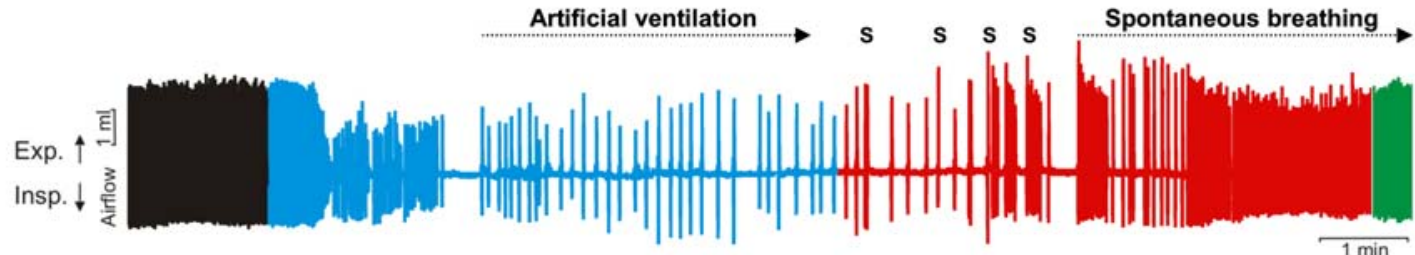

B

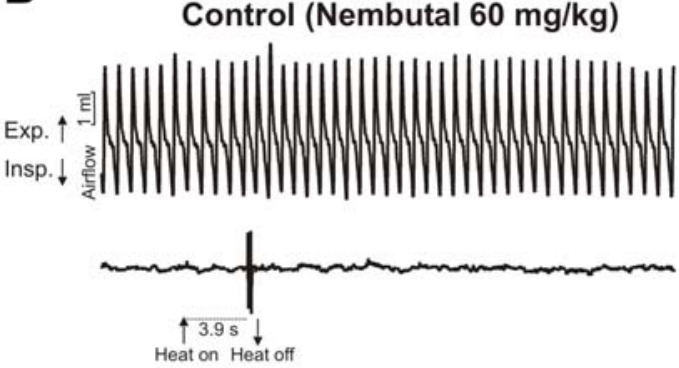

D

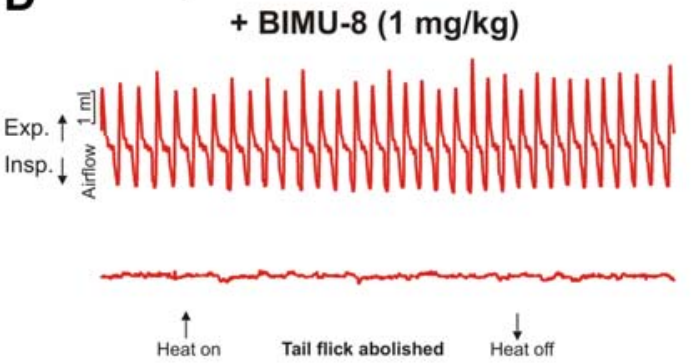

C

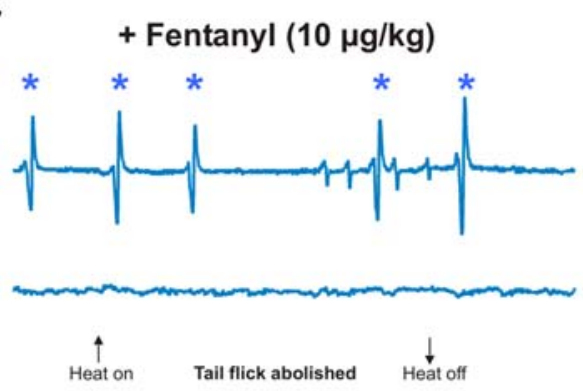

E

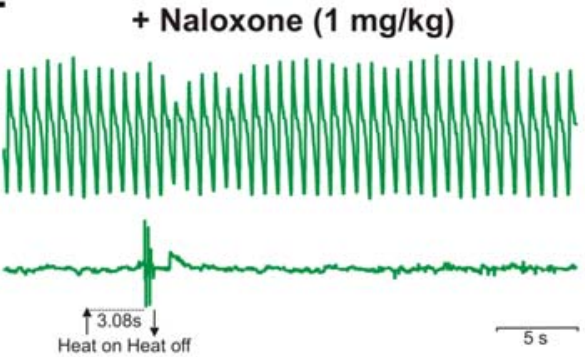

Figure 35. Compensation of the fentanyl-induced depression of breathing by application of BIMU-8 without loss of the analgetic effects of fentanyl:

(A) overview of one example of the in-vivo experiments.

(B) the respiratory airflow of an anaesthetised, spontaneous-breathing, in-vivo rat under pentobarbital application $(60 \mathrm{mg} / \mathrm{kg}$ ) is shown (black trace). Under control conditions, a quick TFR (3.9 s) was obtained.

(C) the application of $10-15 \mu \mathrm{g} / \mathrm{kg}$ fentanyl (blue trace) induced a marked reduction in RMV to $3.9 \pm$ $8.5 \%$ of the control RMV. The TFR was completely abolished after application of fentanyl.

(D) the consecutive application of $1-2 \mathrm{mg} / \mathrm{kg}$ of BIMU-8 (red trace) prevailed over the reduction of the RMV induced by the application of fentanyl and restored a stable breathing with RMV recovering to $70.6 \pm 18.1 \%$ of the control RMV in which the absence of the analgetic response remained unchanged.

(E) the application of $1 \mathrm{mg} / \mathrm{kg}$ naloxone (green trace) re-established both the respiratory activity to the control level and the TFR (3.08 s versus $3.9 \mathrm{~s}$ under control conditions).

The asterisks indicate the transient artefacts due to a manual ventilation, which was necessary to rescue the animal during genuine fentanyl treatment. Abbreviations: expiration (Exp.), inspiration (Insp.), spontaneous breathing (s), respiratory minute volume (RMV), tail-flick response (TFR). 


\subsubsection{Expression of $5-\mathrm{HT}_{4(\mathrm{a})}$ receptors in neurones of the spinal cord}

Pain receptor neurones have cell bodies which are located within the dorsal root ganglia whose receptive endings are located within the skin and other body surfaces. They project into the dorsal horn of the spinal cord, make synapses on neurones that eventually project to the thalamus and then to the somatic sensory cortex. Since the analgetic effects of fentanyl were not affected after the application of the $5-\mathrm{HT}_{4(\mathrm{a})}$ receptor agonist BIMU-8, the expression of the $5-\mathrm{HT}_{4(\mathrm{a})}$ and $\mu$-opioid receptors in neurones of the spinal cord (spinal segments C2 - C6, 10 slices for each spinal segment from 3 different animals each) were analysed. The motoneurones of the ventral horn indicated that both receptors were strongly co-expressed, whereas in neurones of the dorsal horn only the $\mu$-opioid receptors were expressed (fig. 36).

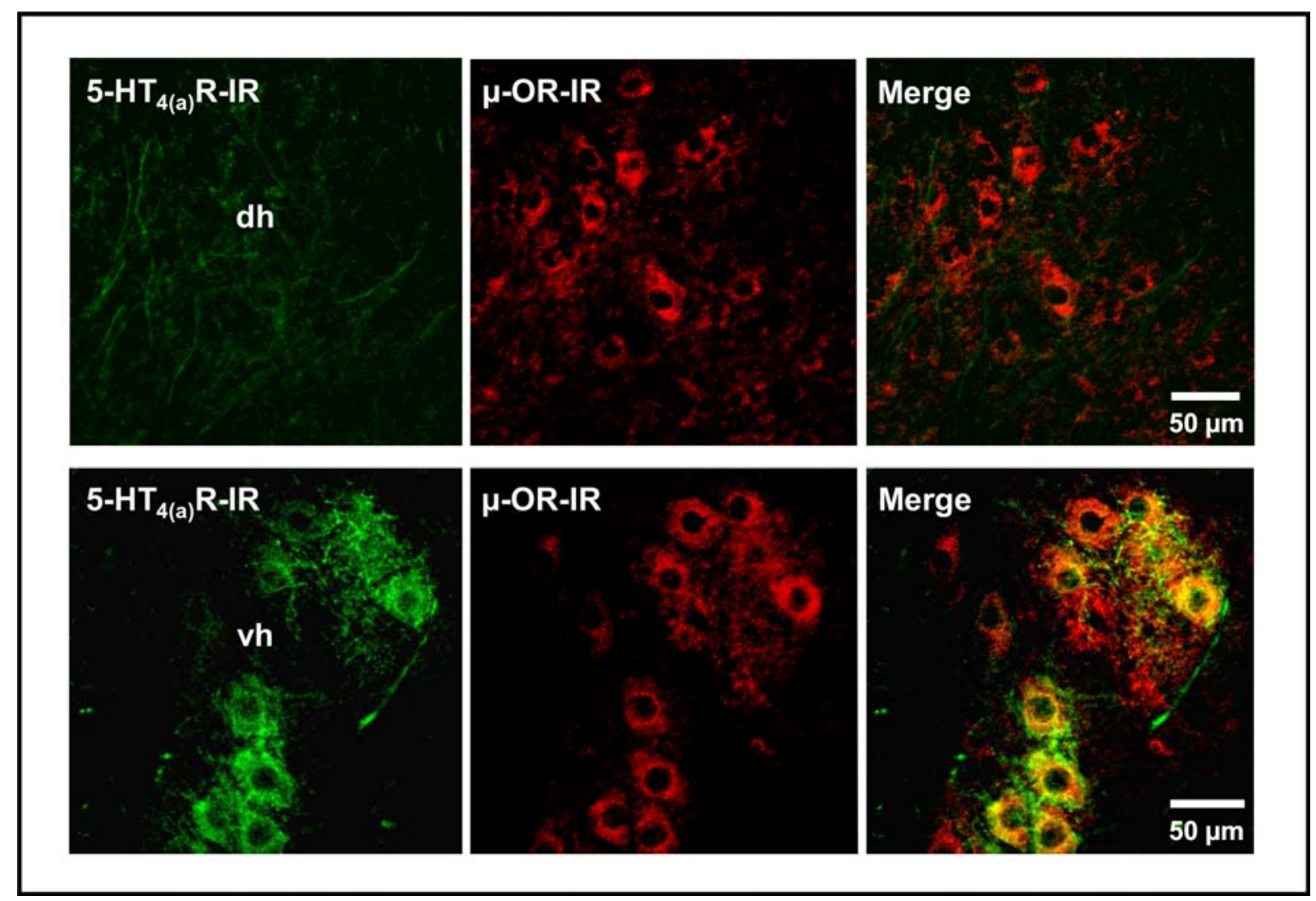

Figure 36. Example of a double labelling of $5-\mathrm{HT}_{4(\mathrm{a})} \mathrm{R}$ and $\mu-\mathrm{OR}$ in neurones of the spinal cord: in contrast to the intense $\mu$-opioid receptor immunoreactivity ( $\mu$-OR-IR), a clear $5-\mathrm{HT}_{4(\mathrm{a})}$ receptor immunoreactivity $\left(5-\mathrm{HT}_{4(\mathrm{a})} \mathrm{R}-\mathrm{IR}\right)$ was missing in dorsal horn interneurones. On the top: a double labelling of $5-\mathrm{HT}_{4(\mathrm{a})}$ receptors (Alexa 488, green colour) and $\mu$-opioid receptors (Alexa 546, red colour) with appropriate antibodies in the dorsal horn region (transversal 40- $\mu \mathrm{m}$-slice) at the C5 - C6 level. At the bottom panels: as a control, a double labelling of $5-\mathrm{HT}_{4(\mathrm{a})}$ receptors (Alexa 488, green colour) and $\mu$ opioid receptors (Alexa 546, red colour) was analysed in the ventral horn region (transversal 40- $\mu \mathrm{m}$ slice) of the spinal segments C2 - C6. The motoneurones of the ventral horn indicated a strong coimmunoreactivity for both the $\mu$-opioid and the 5- $\mathrm{HT}_{4(\mathrm{a})}$ receptors. Abbreviations: dorsal horn (dh), ventral horn (vh).

The strong co-expression of the $5-\mathrm{HT}_{4(\mathrm{a})}$ and $\mu$-opioid receptors in neurones within the $\mathrm{PBC}$, the absence of $5-\mathrm{HT}_{4(\mathrm{a})} \mathrm{R}$-immunoreactive neurones within the dorsal horn, and the results of the in-vivo experiments suggest an efficient convergent antagonistically operating signal transduction pathway of both receptors which will be described in detail in the discussion part (see 4.1.). 


\subsection{Expression of the $5-\mathrm{HT}_{4(\mathrm{a})}$ and $\mu$-opioid receptors in the preBötzinger complex (PBC) of the rat during the development}

The development study was performed in collaboration with S. Preusse (department of neuroanatomy, university of Göttingen). Selective activation of $5-\mathrm{HT}_{4(\mathrm{a})}$ receptors $\left(5-\mathrm{HT}_{4(\mathrm{a})} \mathrm{R}\right)$ compensate the opioid-induced depression of the respiratory activity without loss of analgesia in juvenile Sprague-Dawley rats as was previously shown (see 3.2.). Ballanyi et al. (1997) demonstrated that the opioid-induced respiratory depression is due to a decrease in the cyclic adenosine $3^{\prime}, 5^{\prime}$-monophosphate (cAMP) levels in cells which are responsible for the respiratory rhythm generation or provide a tonic drive to the respiratory network. Since $5-\mathrm{HT}_{4(\mathrm{a})}$ receptors, which increase the intracellular cAMP [Heine et al. (2002)], and the $\mu$-opioid receptors, which decrease the intracellular cAMP, were strongly co-expressed in neurones within the preBötzinger complex $(\mathrm{PBC})$, both receptors regulate in an antagonistic manner the intracellular cAMP concentration. The absence of $5-\mathrm{HT}_{4(\mathrm{a})} \mathrm{R}$-immunoreactive neurones within the dorsal horn allows for continuity of the opioid-induced analgesia. In contrast to the $5-\mathrm{HT}_{4(\mathrm{a})}$ receptors, the $\mu$-opioid receptors were abundantly expressed in dorsal horn neurones. The intention of the development study was, on the one hand, to analyse whether the anatomical conditions, which were demonstrated in juvenile rats, exist during the development and, on the other hand, to test whether the $5-\mathrm{HT}_{4(\mathrm{a})}$ receptor expression pattern alters during the development. Furthermore, the degree of differentiation of the PBC was additionally analysed using the intermediate filament protein nestin which has been suggested as a marker for progenitor cells of the neuroepithelium [Lendahl et al. (1990)]. Using the fetal rat brainstem-spinal cord in-vitro preparation, Di Pasquale et al. (1992) demonstrated that the fetal 'respiratorylike activity ' did not occur until the development stage E 15 and appeared for the first time at the development stage E 16 in 30\% of the preparations with fluctuating frequency and amplitude bursts. At the development stages E 18 - E 20, the fetal respiratory-like activity is similar to the neonate [Greer et al. (1992), Smith et al. (1990)] and stable at the development stage E 20 [Di Pasquale et al. (1992), Onimaru et al. (2002)]. On this account, the embryonic development stages $E$ 14, E 16, E 18 , and $E 20$ were selected for the study. The neo-/postnatal development was analysed for $P 1, P 4, P 7$, and $P$ 10. The appearance of the principal nucleus of the inferior olive [Schwarzacher et al. (1995)] and the substance P-reactive neurokinin-1 receptor, which has been suggested as a potential marker for the embryonic and postnatal preBötzinger complex (PBC) [Gray et al. (1999), Pagliardini et al. (2003)], were used as the criteria for the anatomical identification of the PBC which is known in adult rats to lie ventral to the nucleus ambiguus, caudal to the retrofacial nucleus, and rostral to the anterior tip of the lateral reticular nucleus at the Bregma-level from $-12.0 \mathrm{~mm}$ to $-12.5 \mathrm{~mm}$. [Gray et al. (1999), Guyenet and Wang (2001), Paxinos and Watson (1986), Wang et al. (2001)].

\subsubsection{Analysis of the mRNA expression specific for the $5-\mathrm{HT}_{4(\mathrm{a})}, \mu$-opioid, and NK-1 receptors and the nestin protein in the PBC or its precursor structure}

Prior to the analysis of all proteins on protein level, the $\mathrm{PBC}$ or its precursor structure dissected from embryonic (E 16, E 18, and E 20) and neo-/postnatal (P 0, P 1, P 5, and $P$ 7) slices was analysed ( $n=3$, two patches of both sides from 3 different animals each were combined for 1 sample) for mRNA expression specific for the 5$\mathrm{HT}_{4(\mathrm{a})}, \mu$-opioid, and NK-1 receptors, and the nestin protein using RT-PCR. The specific amplicons for all proteins were detectable within the PBC or its precursor structure during the development (fig. 37). 


\section{- Results -}
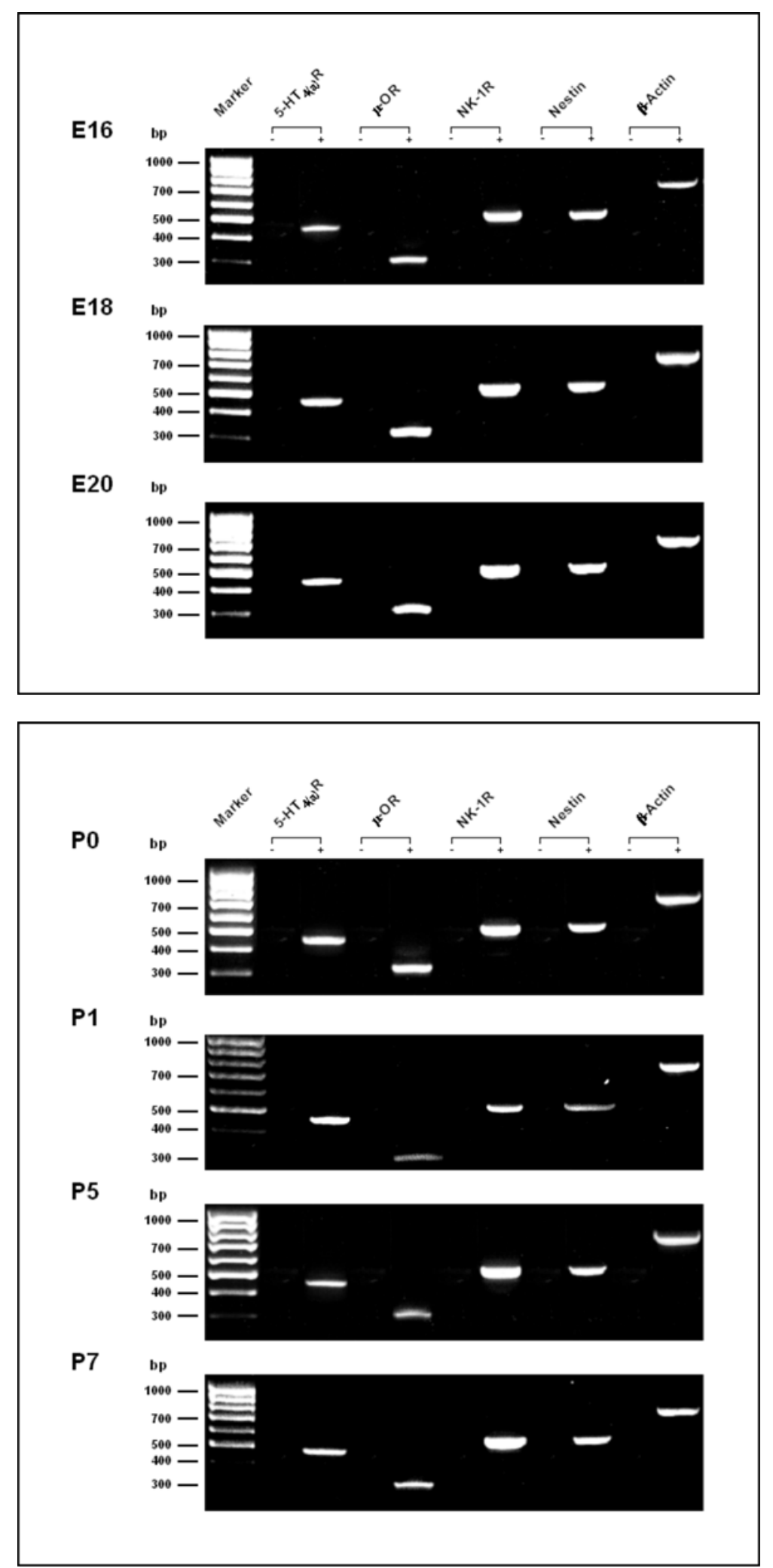

Figure 37. On the top: RT-PCR analysis of the embryonic preBötzinger complex: the $5-H T_{4(a)} R-$, $\mu-O R-$, NK-1R-, and nestin-specific mRNAs were detectable in the PBC (E 16, E 18, and E 20) dissected from embryonic slice preparations. At the bottom panels: RT-PCR analysis of the neoIpostnatal preBötzinger complex: the $5-\mathrm{HT}_{4(\mathrm{a})} \mathrm{R}-, \mu \mathrm{-OR}-, \mathrm{NK}-1 \mathrm{R}-$, and nestin-specific mRNAs were also detectable in the PBC (P 0, P 1, P5, and P 7) dissected from neo-/postnatal slice preparations. Samples without reverse transcriptase (-) served as negative controls. The 'housekeeping gene ' $\beta$ actin was used as an internal standard. The amplification products were partially sequenced for their identification. 


\subsubsection{5- $\mathrm{HT}_{4(\mathrm{a})}$ receptor expression in the $\mathrm{PBC}$ of the rat during the development}

For the immunohistochemical analysis 10 slices of 5 different animals each for the corresponding development stage were used. The $5-\mathrm{HT}_{4(\mathrm{a})}$ receptor expression was observable for the first time at the development stage $E 14$ in neurones of motor nuclei e.g. the hypoglossal (XII) and facial nucleus (VII) within the brainstem. Since the ambigual nucleus and the principal nucleus of the inferior olive are not formed at the development stage $\mathrm{E} 14$, a definite relation of $5-\mathrm{HT}_{4(\mathrm{a})}$ receptor-immunoreactive $\left(5-\mathrm{HT}_{4(\mathrm{a})} \mathrm{R}\right.$-ir) neurones to the PBC or its precursor structure was not possible. At the development stage $\mathrm{E} 16$, the $5-\mathrm{HT}_{4(\mathrm{a})}$ receptor immunoreactivity (-IR) was restricted to the ambigual nucleus (fig. 38 and 39). An extensive 5- $\mathrm{HT}_{4(\mathrm{a})}$ receptor staining of neuropil, which is defined as a dense intricate feltwork of interwoven fine glial processes, fibrils, synaptic terminals, axons, and dendrites interspersed among the nerve cells in the gray matter of the central nervous system, were visible at the development stage $\mathrm{E}$ 18. At this development stage, the $5-\mathrm{HT}_{4(\mathrm{a})} \mathrm{R}$-ir neurones were closely localised to the ambigual nucleus (fig. 38 and 39). The double labelling of 5$\mathrm{HT}_{4(\mathrm{a})}$ and NK-1 receptors (fig. 40) indicated that the neuropil staining was nearly restricted to the anatomical extension of the PBC. In the development stages P $0-P 3$ the neuropil staining decreased and was later absent $(P 4)$ in which the $5-H_{4} T_{4(a)} R$-ir neurones were more distantly localised to the ambigual nucleus within the PBC (P 4 $P$ 10). At all development stages which had been analysed, the 5- $\mathrm{HT}_{4(\mathrm{a})}$ receptor was only sporadically expressed in somatosensory regions.

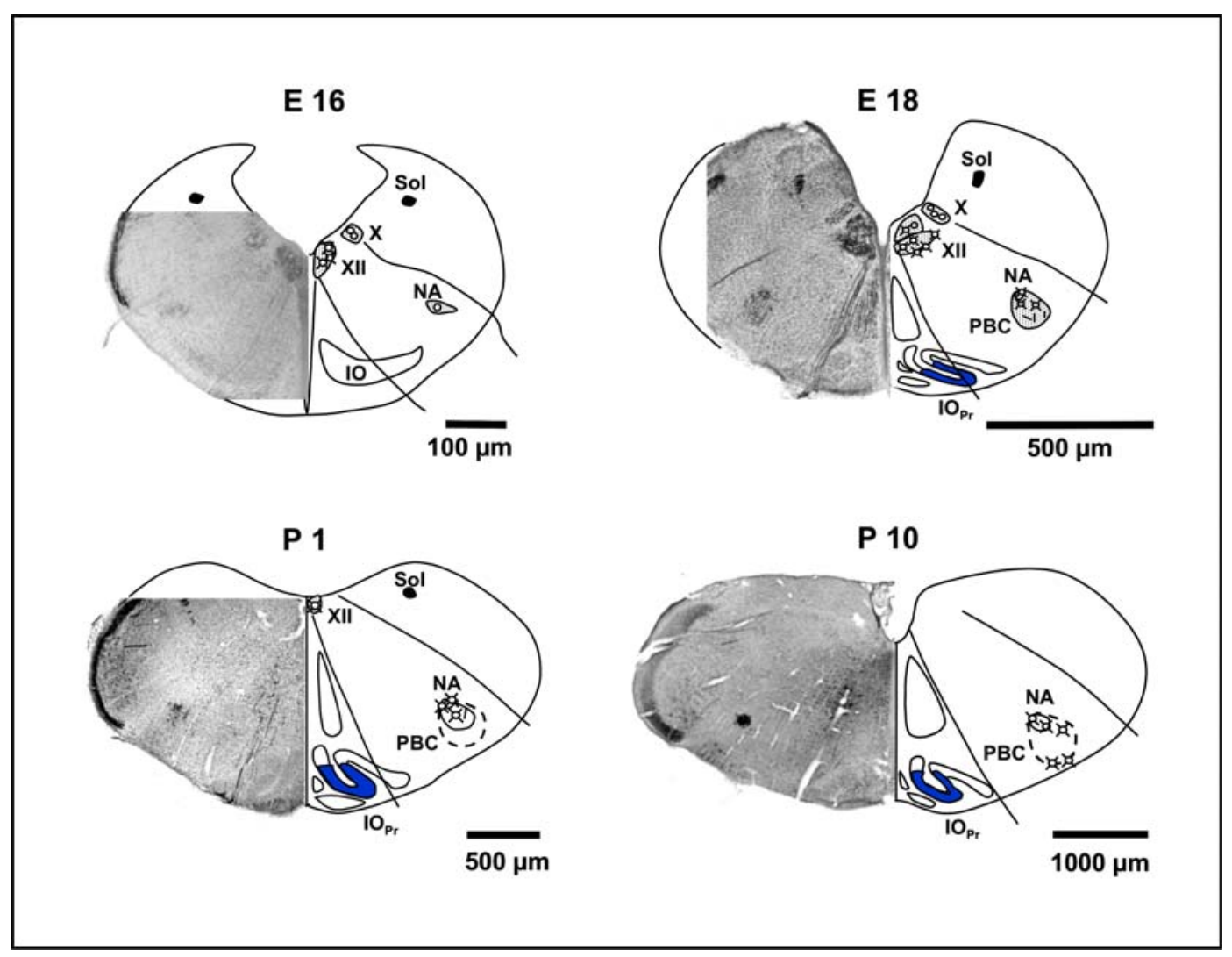

Figure 38. Overview of the $5-\mathrm{HT}_{4(\mathrm{a})} \mathrm{R}$ immunoreactivity in the rat preBötzinger complex or its precursor structure: abbreviations: embryonic day $(E)$, postnatal day $(P)$, ambigual nucleus (NA), preBötzinger complex (PBC), hypoglossal nucleus (XII), vagal nucleus (X), nucleus solitary tract (Sol), principal nucleus of the inferior olive $\left(\mathrm{IO}_{\mathrm{Pr}}\right)$. 


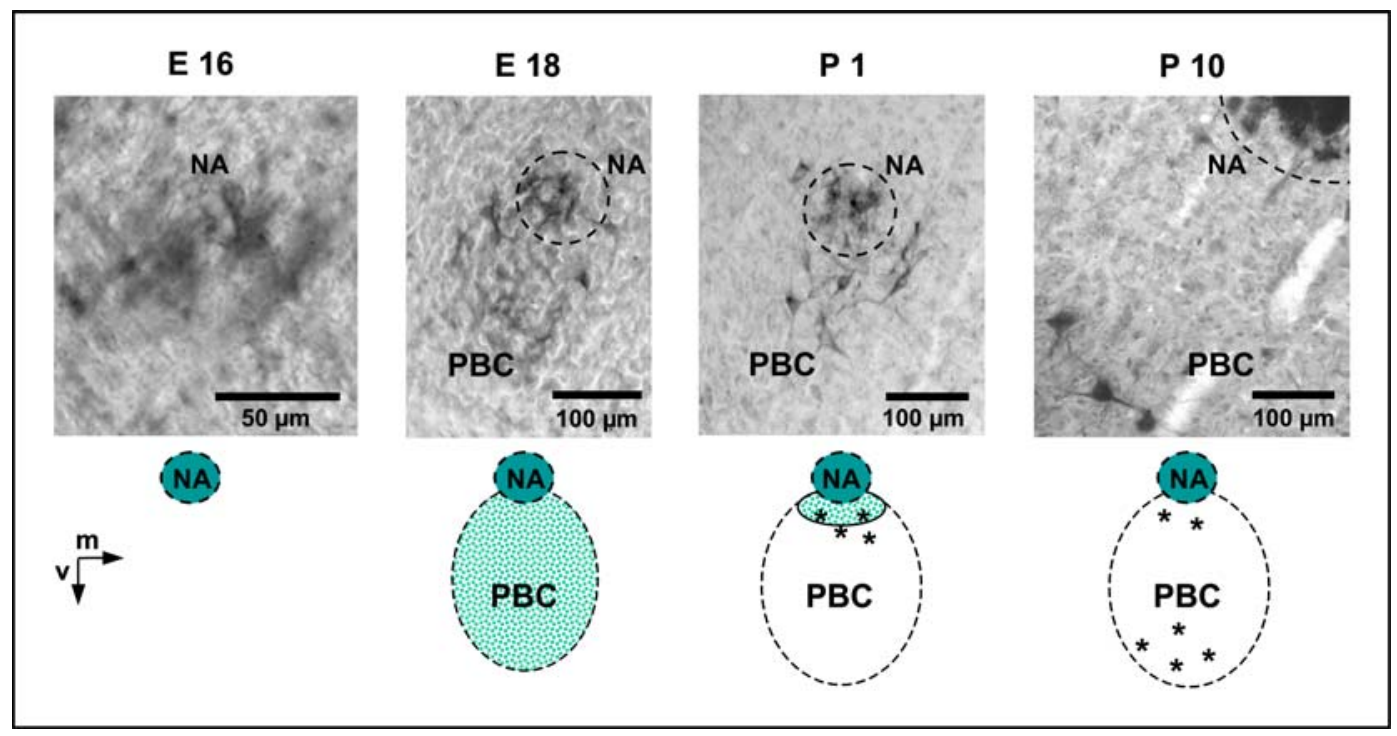

Figure 39. Alteration of the $5-\mathrm{HT}_{4(\mathrm{a})} \mathrm{R}$ immunoreactivity pattern: the schematic representations illustrate the alteration of the $5-\mathrm{HT}_{4(\mathrm{a})} \mathrm{R}$ immunoreactivity. The punctuated green area marks the 5$\mathrm{HT}_{4(\mathrm{a})} \mathrm{R}$ neuropil staining. Abbreviations: medial (m), ventral (v).

\subsubsection{Co-expression of the 5-HT $4(a)$ and $\mathrm{NK}-1$ receptors in neurones within the PBC during the development}

The double stainings of the $5-\mathrm{HT}_{4(\mathrm{a})}$ and NK-1 receptors (10 slices of 5 different animals each for the corresponding development stage) indicated that the 5-HT $\mathrm{H}_{4(\mathrm{a})} \mathrm{R}$ immunoreactive neurones were indeed localised within the PBC (fig. 40) which showed the highest density and strength of the NK-1R-immunoreactivity.

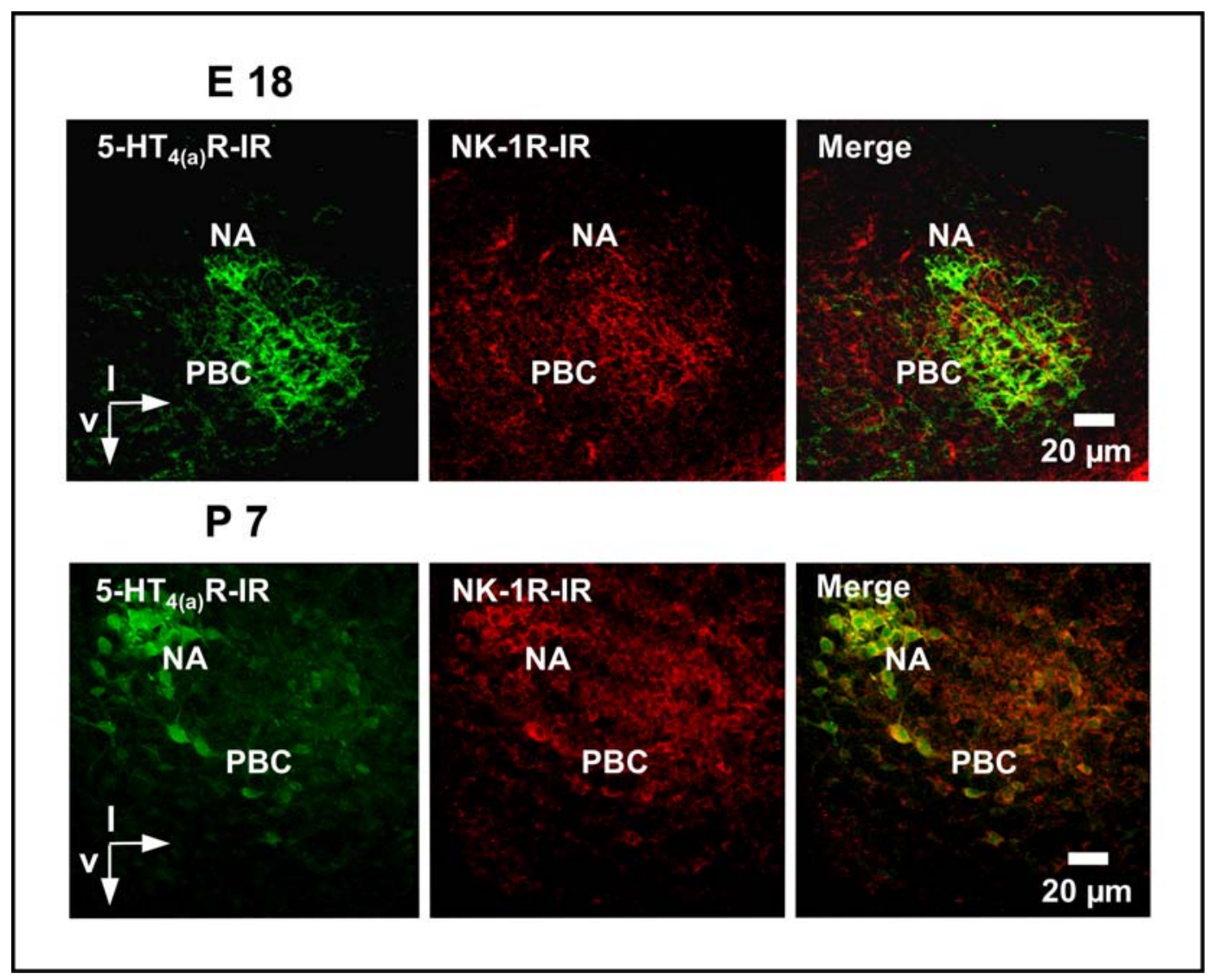


Figure 40. Double labelling of 5- $\mathrm{HT}_{4(\mathrm{a})}$ and NK-1 receptors in neurones of the PBC: two examples (E 18 and $P$ 7) which show that the $5-\mathrm{HT}_{4(\mathrm{a})}$ (Alexa 488, green colour) and the NK-1 receptors (Alexa 546 , red colour) were co-expressed (overlay of both labellings resulted in yellow colour indicating coexpression) which ensured that the $5-\mathrm{HT}_{4(\mathrm{a})} \mathrm{R}$-ir neurones were indeed localised within the PBC during the development stages. Abbreviations: preBötzinger complex (PBC), ambigual nucleus (NA), immunoreactivity (IR), immunoreactive (ir), lateral (I), ventral (v).

\subsubsection{Co-expression of the $5-\mathrm{HT}_{4(\mathrm{a})}$ and $\mu$-opioid receptors in the PBC during the development}

The co-expression of $5-\mathrm{HT}_{4(\mathrm{a})}$ and $\mu$-opioid receptors in neurones within the PBC is a precondition for a convergent signal transduction pathway of both receptors. The 5$\mathrm{HT}_{4(\mathrm{a})}$ receptor was strongly co-expressed with the $\mu$-opioid receptor ( $\mu$-OR) during all development stages which had been analysed (5 slices from 5 different animals each for the respective development stage). All 5- $\mathrm{HT}_{4(\mathrm{a})} \mathrm{R}$-immunoreactive (-ir) neurones did also express the $\mu$-OR (fig. 41) as had previously been shown in slices from juvenile rats (see 3.2.1.).

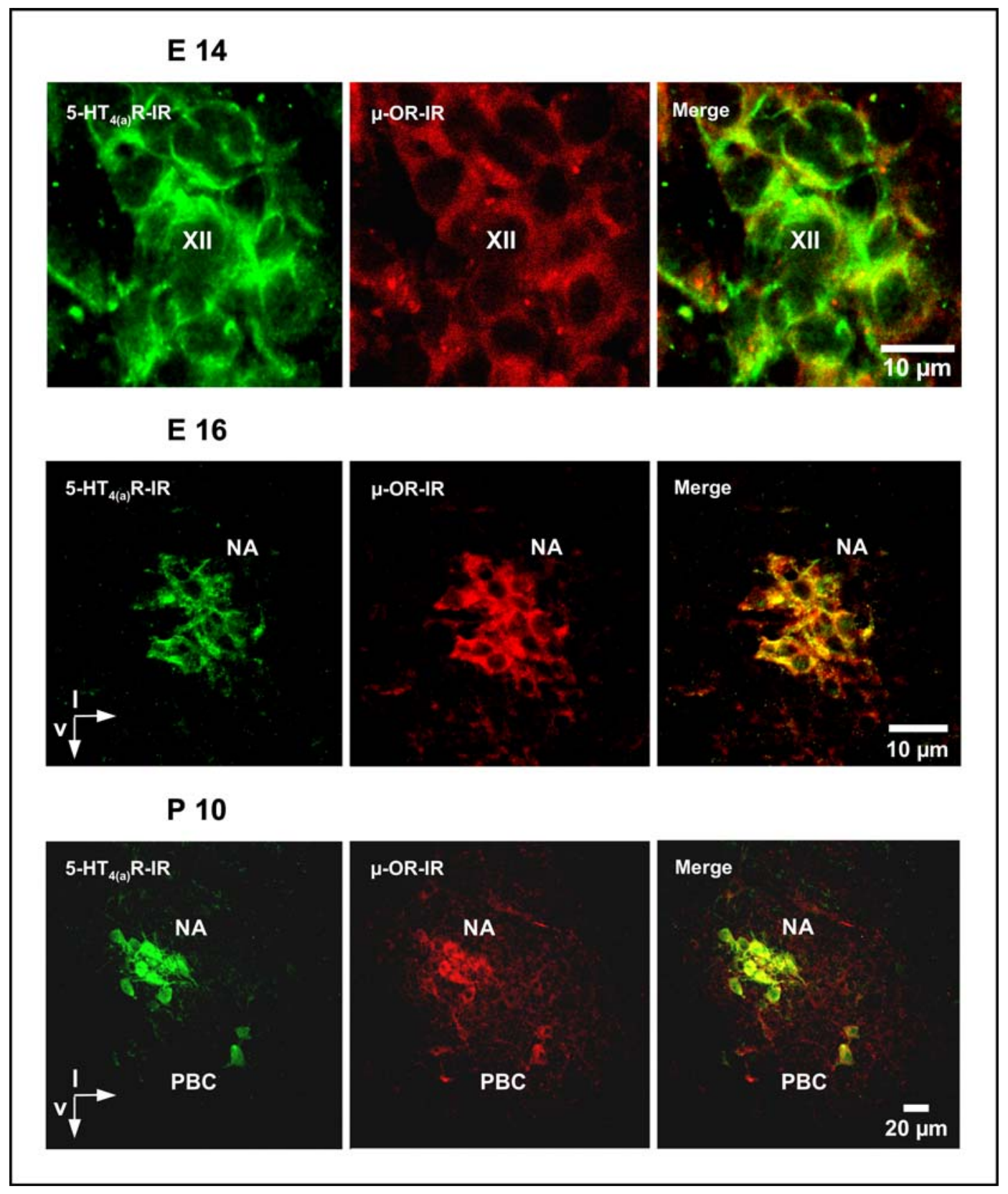


Figure 41. Double labelling of the $5-\mathrm{HT}_{4(\mathrm{a})}$ and $\mu$-opioid receptors during the development: on the top and in the middle examples of the strong co-expression of 5- $\mathrm{HT}_{4(\mathrm{a})}$ and $\mu$-opioid receptorimmunoreactive neurones of motor nuclei (E 14, hypoglossal nucleus; $E$ 16, ambigual nucleus) are shown. The expression of the $5-\mathrm{HT}_{4(\mathrm{a})}$ receptor at the development stage $\mathrm{E} 16$ was restricted to neurones within the ambigual nucleus. At the bottom panels the co-expression is shown for neurones of the preBötzinger complex (PBC) at the development stage $P$ 10. All neurones which expressed the $5-\mathrm{HT}_{4(\mathrm{a})}$ receptor did also express the $\mu$-opioid receptor. Abbreviations: preBötzinger complex (PBC), hypoglossal nucleus (XII), ambigual nucleus (NA), lateral (I), ventral (v).

The expression of the $5-\mathrm{HT}_{4(\mathrm{a})}$ and $\mu$-opioid receptors on protein level at the development stages E 14, E 16, E 20, P 1, and P 4 was confirmed by immunoblot analysis ( $\mathrm{n}$ =3). To obtain an appropriate amount of protein, the whole embryo (E 14 and $E 16)$ or the isolated brainstem (E 20, P 1, and P 4) were lysed using Triton X-100 (2 animals for each development stage). The adequate antibodies detected a specific signal at about $46 \mathrm{kDa}$ for the $5-\mathrm{HT}_{4(\mathrm{a})}$ receptor or a signal at about $45 \mathrm{kDa}$ for the $\mu$ opioid receptor which was in accordance with the predicted molecular mass of the corresponding receptor.

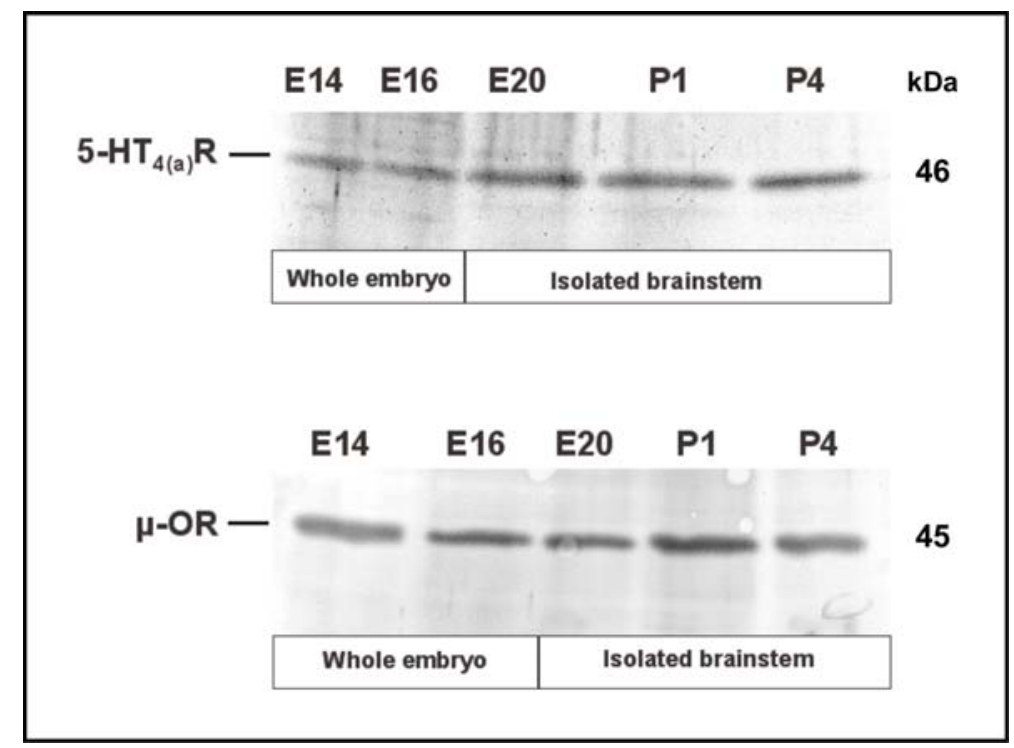

Figure 42. Immunoblot analysis: two hundred and fifty microgram protein of the whole embryo Triton $X-100$ lysate (E 14 and E 16) or $250 \mu \mathrm{g}$ protein of the isolated brainstem Triton X-100 lysate (E 20, P 1 , and P 4) was subjected to a SDS-PAGE using a Maxigel $\left(17 \times 18 \mathrm{~cm}^{2}\right)$, transferred to a membrane, and then applied with the polyclonal monospecific anti-5- $\mathrm{HT}_{4(\mathrm{a})}$ receptor antibody from rabbit or the polyclonal anti- $\mu$-opioid receptor antibody from guinea pig. DAB was used as a chromogen. The specific signal for the $5-\mathrm{HT}_{4(\mathrm{a})}(46 \mathrm{kDa})$ or $\mu$-opioid receptors (45 kDa) was detectable in embryonic and neo-/postnatal development stages (E 14, E 16, E 20, P 1, and P 4). 

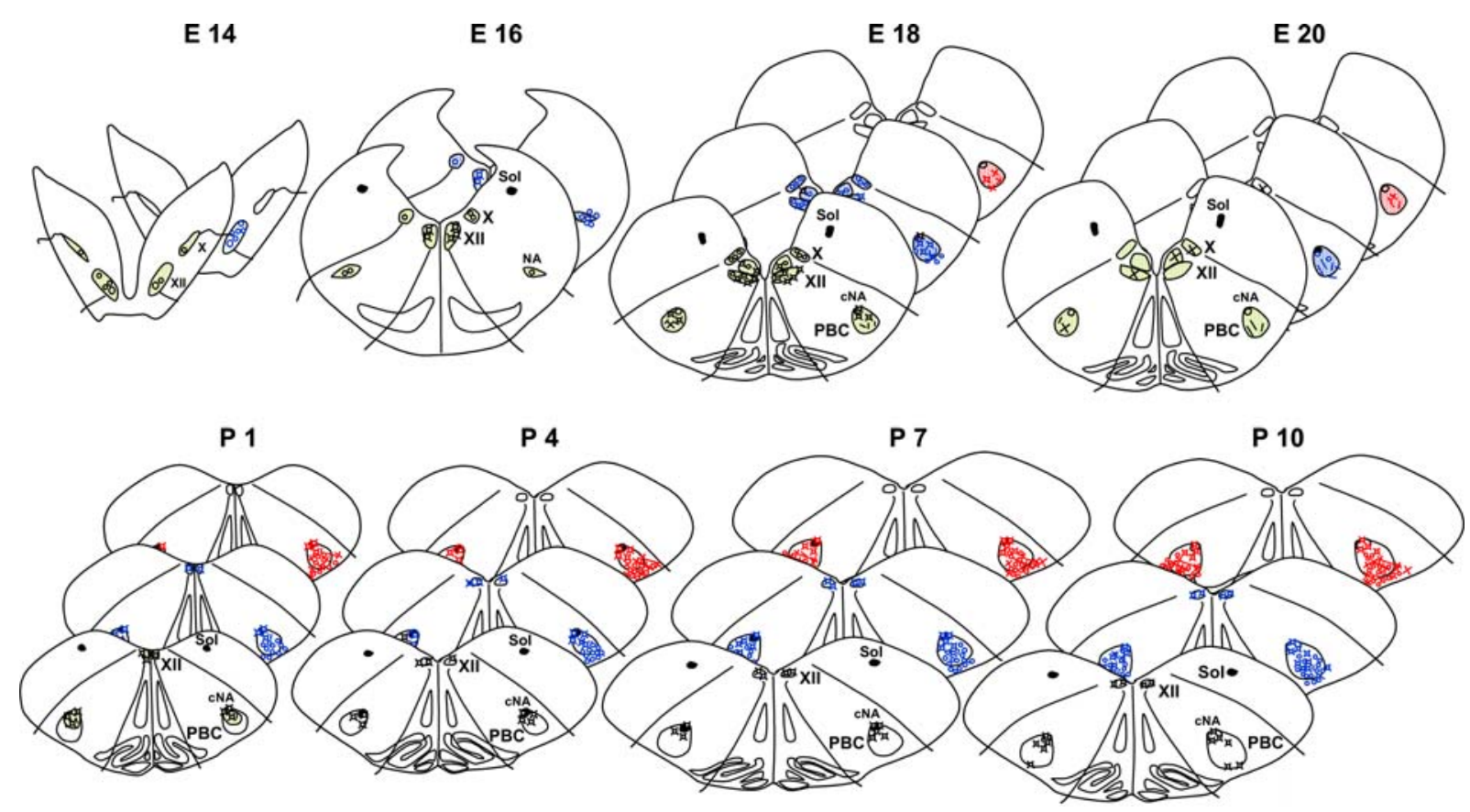

Figure 43. Comprising schematic representation of the distribution of $5-\mathrm{HT}_{4(\mathrm{a})}$, $\mu$-opioid, and NK-1 receptor-immunoreactive neurones within the PBC during the development: distinct NK$1 R$-ir neurones (red colour) were visible for the first time at the development stage $E 18$. The first $\mu$ OR-ir neurones (blue colour) were localised within the hypoglossal nucleus (E 14) and the ambigual nucleus (E 16). During later periods of development, $\mu$-opioid receptors were abundantly expressed. The 5- $\mathrm{HT}_{4(\mathrm{a})} \mathrm{R}$-ir neurones (black colour) were stained for the first time in motor nuclei like the hypoglossal (E 14) and ambigual nucleus (E 16). At the development stage $E 18$, the $5-H T_{4(a)} R$-ir neurones were closely localised to the ambigual nucleus. At this stage, an extensive $5-\mathrm{HT}_{4(\mathrm{a})} \mathrm{R}$ neuropil staining (green colour), which had been nearly restricted to the anatomical extension of the PBC, occurred. The neuropil staining decreased during later periods of development in which the $5-\mathrm{HT}_{4(\mathrm{a})} \mathrm{R}$-ir neurones were more distantly localised to the ambigual nucleus within the PBC. Abbreviations: preBötzinger complex (PBC), nucleus ambiguus pars compacta (CNA), nucleus solitary tract (Sol), hypoglossal nucleus (XII), vagal nucleus (X), immunoreactive (ir).

\subsubsection{Analysis of the $5-\mathrm{HT}_{4(\mathrm{a})}$ and $\mu$-opioid receptor expression in neurones of the spinal cord}

The in-vivo experiments (see 3.2.3.) demonstrated that the opioid-induced analgesia was not affected after the selective stimulation of the $5-\mathrm{HT}_{4(\mathrm{a})}$ receptor which based on the absence of $5-\mathrm{HT}_{4(\mathrm{a})}$ receptor expression on protein level in neurones within the dorsal horn. Therefore, it was analysed whether the anatomical conditions of the juvenile/adult rats exist during the development.

The analysis of the co-expression of the $5-\mathrm{HT}_{4(\mathrm{a})}$ and $\mu$-opioid receptors in neurones of the spinal cord [10 slices of 3 different spinal segments [cervical (C4 - C6), thoracic (TH5 - TH7), and lumbar (L2 - L4)] each from 5 different animals each for all development stages which had been analysed] revealed the absence of $5-\mathrm{HT}_{4(\mathrm{a})} \mathrm{R}$-immunoreactive neurones within the dorsal horn during all development stages (fig. 44). In contrast to the dorsal horn, the motoneurones of the ventral horn, which had been analysed as a control, expressed both receptors in which all $5-\mathrm{HT}_{4(\mathrm{a})} \mathrm{R}$-immunoreactive neurones did also express the $\mu$-opioid receptor. 


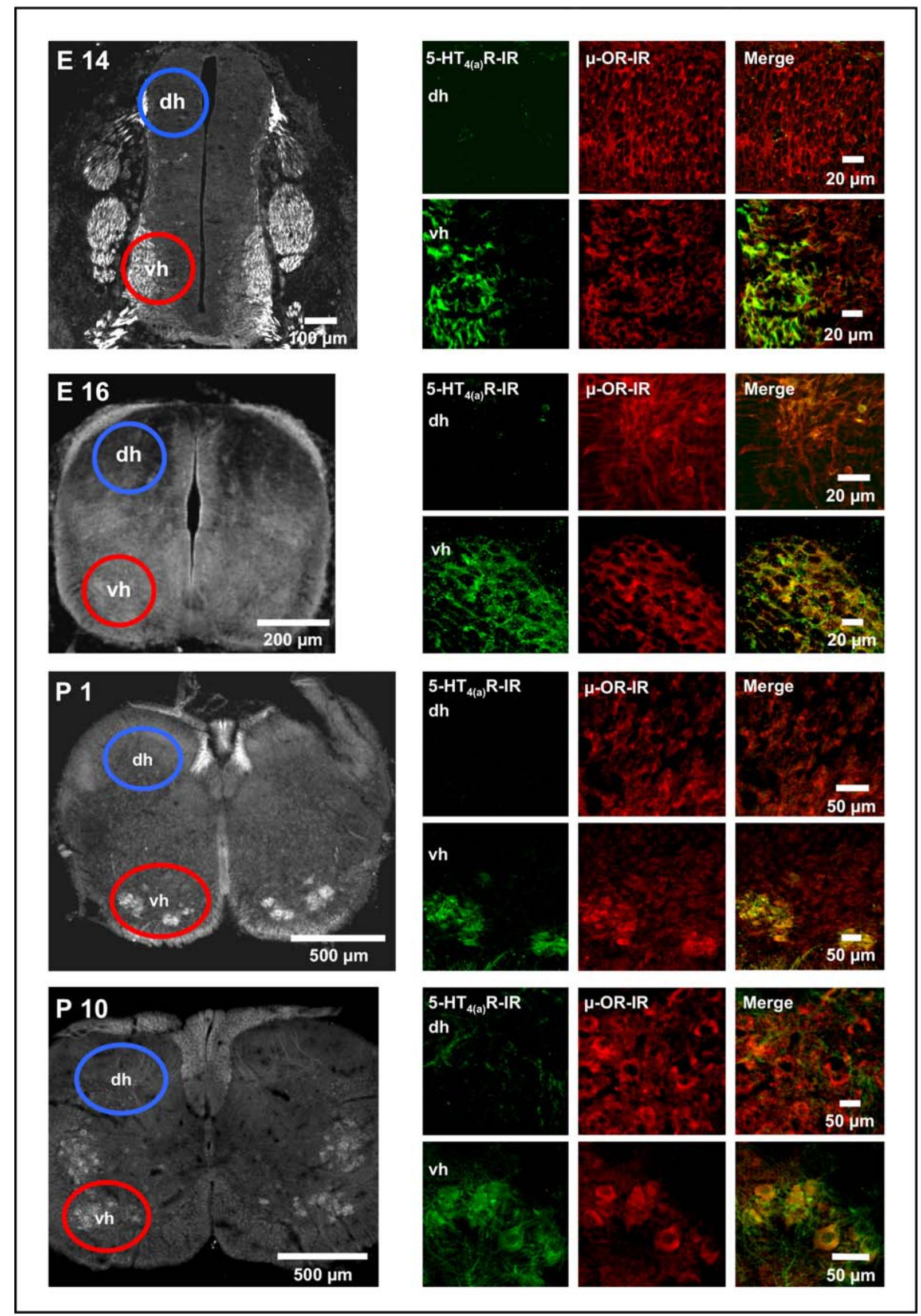

Figure 44. Expression of the $5-\mathrm{HT}_{4(\mathrm{a})}$ and $\mu$-opioid receptors in neurones of the spinal cord: during the development the $5-\mathrm{HT}_{4(\mathrm{a})}$ and $\mu$-opioid receptors were strongly co-expressed in motoneurones of the ventral horn (vh), whereas an expression of the 5- $\mathrm{HT}_{4(\mathrm{a})}$ receptor in neurones of the dorsal horn (dh) was missed. Cervical spinal cord (E 14), thoracic spinal cord (E 16, P 1, and P 10). 


\subsection{6. $5-\mathrm{HT}_{4(\mathrm{a})}$ receptor expression in identified embryonic respiratory neurones}

Since a specific single marker for respiratory neurones do not exist, identified inspiratory neurones in a rhythmically active slice preparation at the development stage E 19 were filled intracellularly with biocytin in collaboration with Dr. Hülsmann (department of neurophysiology, university of Göttingen) and subsequently analysed for $5-\mathrm{HT}_{4(\mathrm{a})}$ receptor expression on protein level. The immunostainings of the identified neurones revealed the $5-\mathrm{HT}_{4(\mathrm{a})}$ receptor expression in embryonic inspiratory neurones in which $87.5 \%$ ( 7 of 8 cells from 8 different slice preparations) of the identified cells were $5-\mathrm{HT}_{4(\mathrm{a})}$ receptor-immunoreactive.

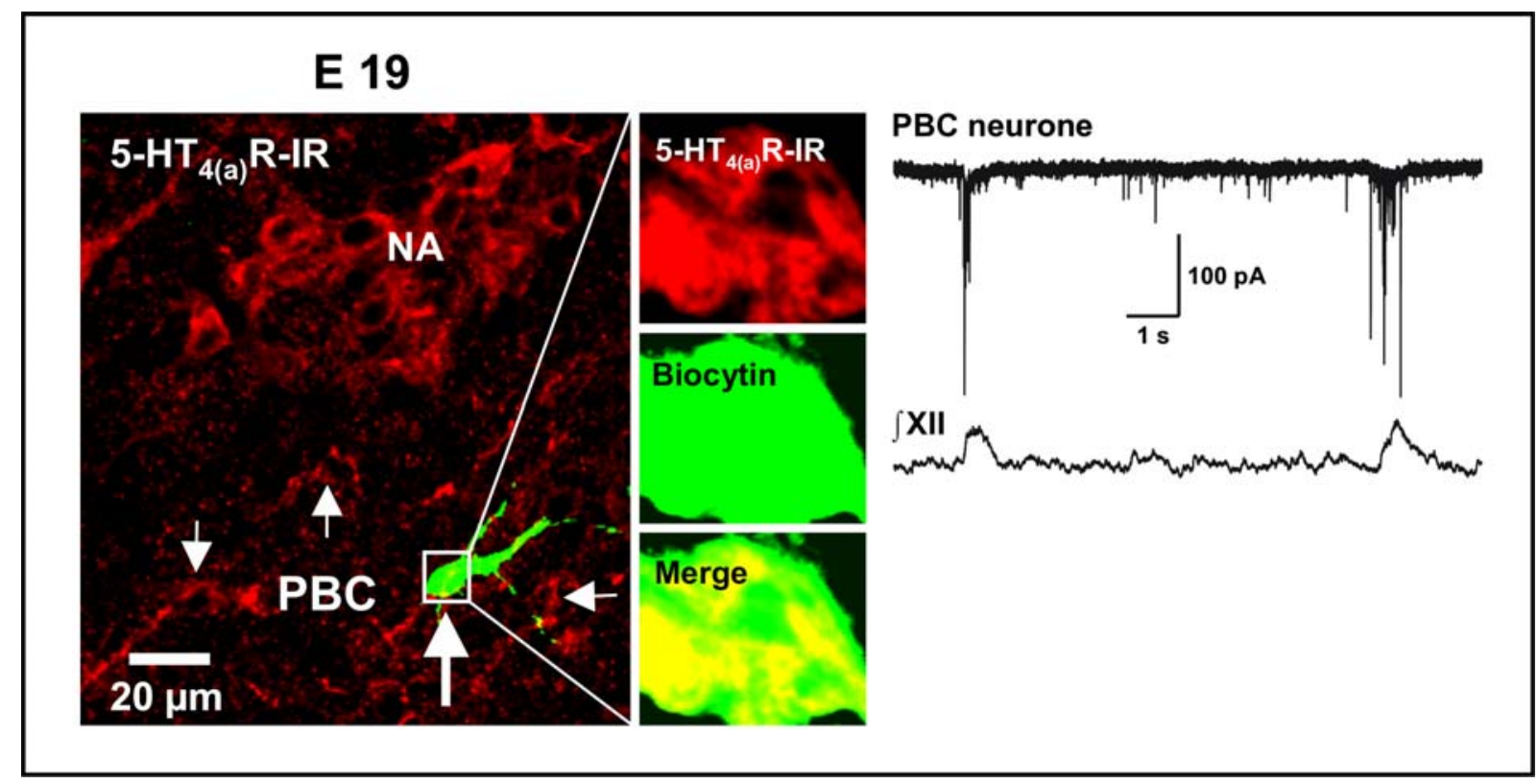

Figure 45. Expression of $5-\mathrm{HT}_{4(\mathrm{a})}$ receptors in identified embryonic respiratory neurones: example of an embryonic inspiratory neurone at the development stage $E 19$ which had been labelled intracellularly with biocytin (Alexa 488-conjugated avidin, green colour) exhibited a strong 5-HT 4 (a) $R-I R$ (Alexa 647, red colour) [big arrow]. The neurone was surrounded by $5-\mathrm{HT}_{4(\mathrm{a})} \mathrm{R}$-immunoreactive somatic profiles [small arrows] within the preBötzinger complex (PBC). Traces (right): the integrated hypoglossal nerve activity ( $\int$ XII) (at the bottom) corresponded to the rhythmic inward currents in the inspiratory neurone which had been recorded in the whole-cell configuration (on the top). Abbreviations: preBötzinger complex (PBC), ambigual nucleus (NA), immunoreactivity (IR). 


\subsubsection{Analysis of the degree of differentiation of the embryonic and neonatal PBC}

\subsubsection{Analysis of the nestin protein expression pattern during embryonic and neonatal development stages}

The intermediate filament protein nestin, which belongs to the six class of the intermediate filament protein family, is the predominant marker for mammalian stem and progenitor cells. Nestin is expressed in the majority of mitotically active CNS and PNS progenitors [Cattaneo and McKay (1990), Lendahl (1997), Lendahl et al. (1990), Mujtaba et al. (1998)]. This protein was used to obtain informations about the degree of differentiation of the embryonic and neonatal preBötzinger complex (PBC) or its precursor structure. For the immunohistochemistry, 10 slices of 5 different animals each were analysed for the corresponding development stage.

At the development stage E 16, nestin-immunoreactive (-ir) cells within the ambigual nucleus and its ventral periphery were absent, whereas a fibre staining occurred. In contrast, a clear distinct cell staining was visible within the dorsolateral periphery of the ambigual nucleus and within the vagal (X) and hypoglossal nucleus (XII) (fig. 47). Prior to birth (E 20), the fibre staining increased in which nestin-ir cells of the PBC, which had been anatomically identified at this development stage by the appearance of the principal nucleus of the inferior olive and the NK-1 receptor immunoreactivity, were stained for the first time (fig. 47). The morphological appearance of these cells was predominantly similar to glial cells. Directly after birth ( $P 0-P 2)$, the number of nestin-ir cells increased dramatically within and outside the PBC in which the neonatal distribution pattern was diffuse.

E 16

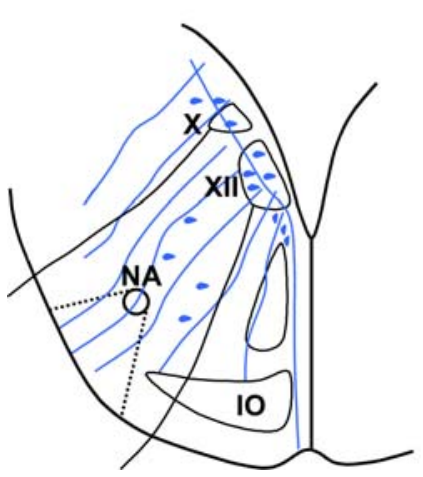

E 20

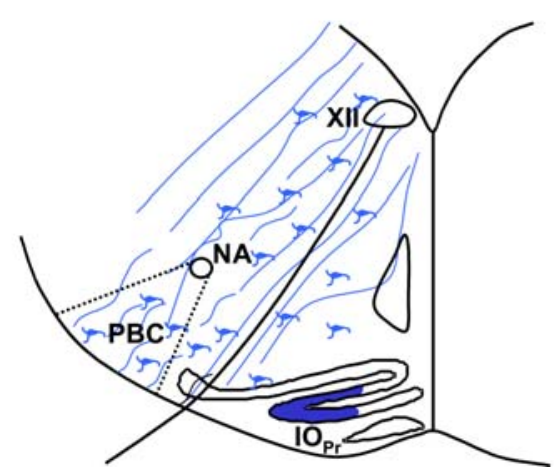

P 1

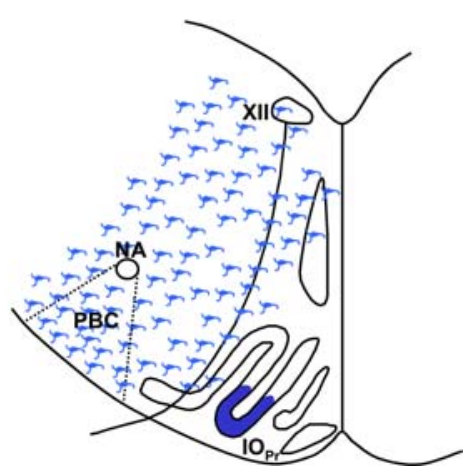

Figure 46. Schematic representation of the alteration of the nestin protein expression pattern: the nestin-immunoreactive fibres (blue colour) passed along within prenatal slices in a dorso-ventral direction. The density of the nestin fibre staining increased from E 16 to E 20 in which nestin-ir cells (blue colour) within the ventral periphery of the ambigual nucleus were stained for the first time at the development stage $E 20$. The number of cells increased directly after birth (P 0 - P 2) in which the cells met morphological criteria of glial cells. Abbreviations: preBötzinger complex (PBC), ambigual nucleus $(\mathrm{NA})$, vagal nucleus $(\mathrm{X})$, hypoglossal nucleus (XII), inferior olive (IO), principal nucleus of the inferior olive $\left(\mathrm{IO}_{\mathrm{Pr}}\right)$. 


\subsubsection{Analysis of the co-expression of the $5-\mathrm{HT}_{4(\mathrm{a})}$ receptor and the nestin protein in cells within the embryonic and neonatal PBC}

At the development stage $E$ 16, isolated nestin-positive cells within the dorso-lateral periphery of the ambigual nucleus and within the vagal $(X)$ and hypoglossal nucleus (XII) expressed the $5-\mathrm{HT}_{4(\mathrm{a})}$ receptor (10 slices of 5 different animals each for the corresponding development stage) (fig. 47). At E 20, an intensive nestin protein fibreand cell-staining within the PBC were visible in which the cells met predominantly morphological criteria of glial cells. These nestin-positive cells expressed only sporadically the $5-\mathrm{HT}_{4(\mathrm{a})} \mathrm{R}$ (fig. 47).

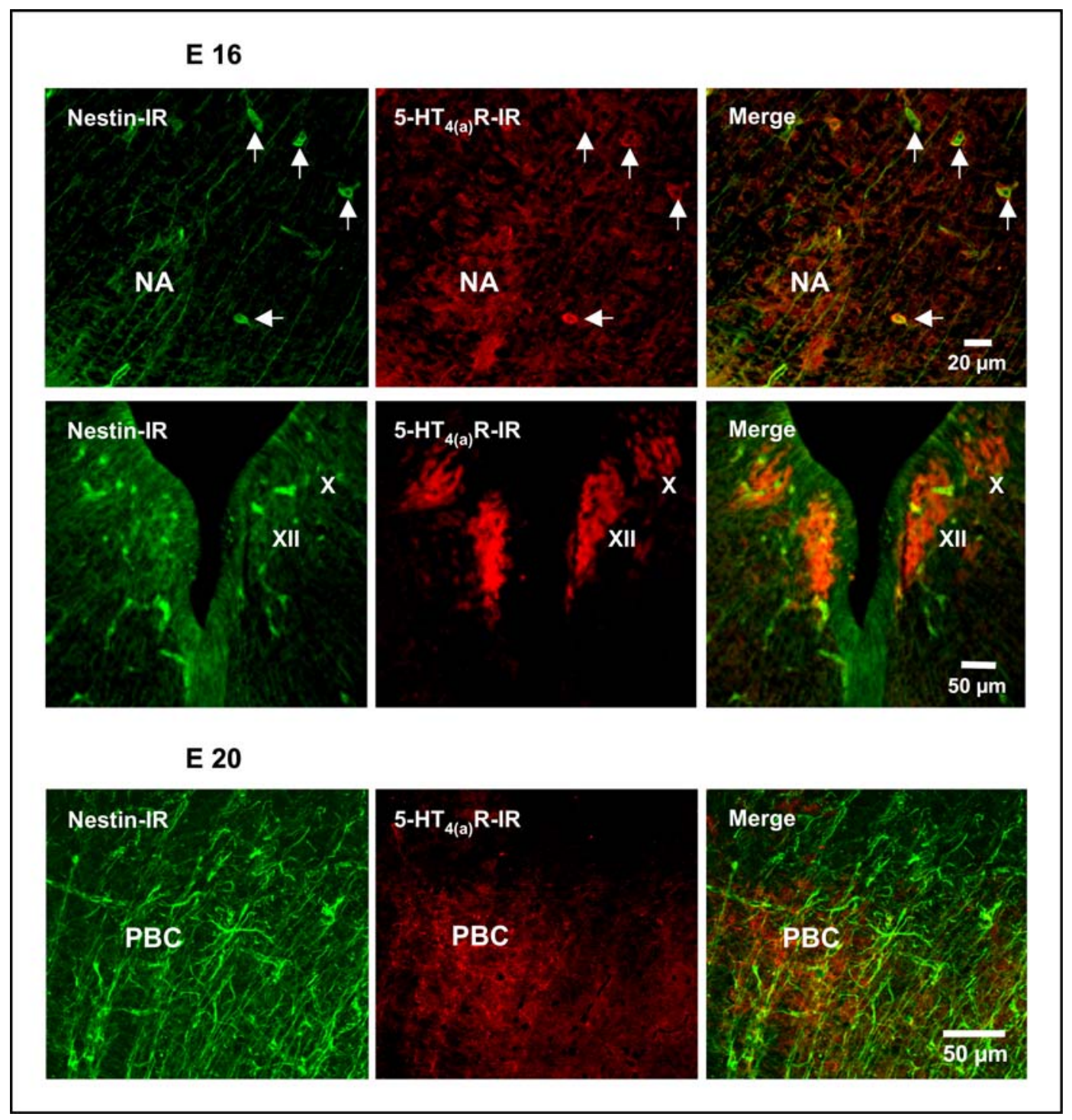

Figure 47. Double labellings of the $5-\mathrm{HT}_{4(\mathrm{a})}$ receptor and nestin: the intermediate filament protein nestin was used as a marker for progenitor cells of the neuroepithelium to obtain informations about the degree of differentiation of the embryonic- and neonatal preBötzinger complex (PBC). On the top: within the nucleus ambiguus (NA) and its ventral periphery, nestin-positive cells (Alexa 488, green colour) were absent at E 16 . In contrast, the nestin protein was expressed in cells within the dorsolateral periphery of the NA (white arrows) and in cells of the vagal (X) and hypoglossal nucleus (XII). At the bottom panels: at the development stage $E 20$, an intensive nestin protein fibre- and cell staining were visible in which the cells expressed only sporadically the $5-\mathrm{HT}_{4(\mathrm{a})}$ receptor. In contrast to the 5- $\mathrm{HT}_{4(\mathrm{a})} \mathrm{R}$-IR (Alexa 546, red colour), the nestin-IR was not restricted to the PBC. Abbreviations: preBötzinger complex (PBC), vagal nucleus (X), hypoglossal nucleus (XII), immunoreactivity (IR), medial $(\mathrm{m})$, ventral (v). 
During neonatal periods of development ( $\mathrm{P} 0$ - $\mathrm{P}$ 2), the $5-\mathrm{HT}_{4(\mathrm{a})}$ receptor and the nestin protein were predominantly co-expressed in cells within the ambigual nucleus whereas only a few cells within its ventral periphery expressed both proteins (fig. 48).

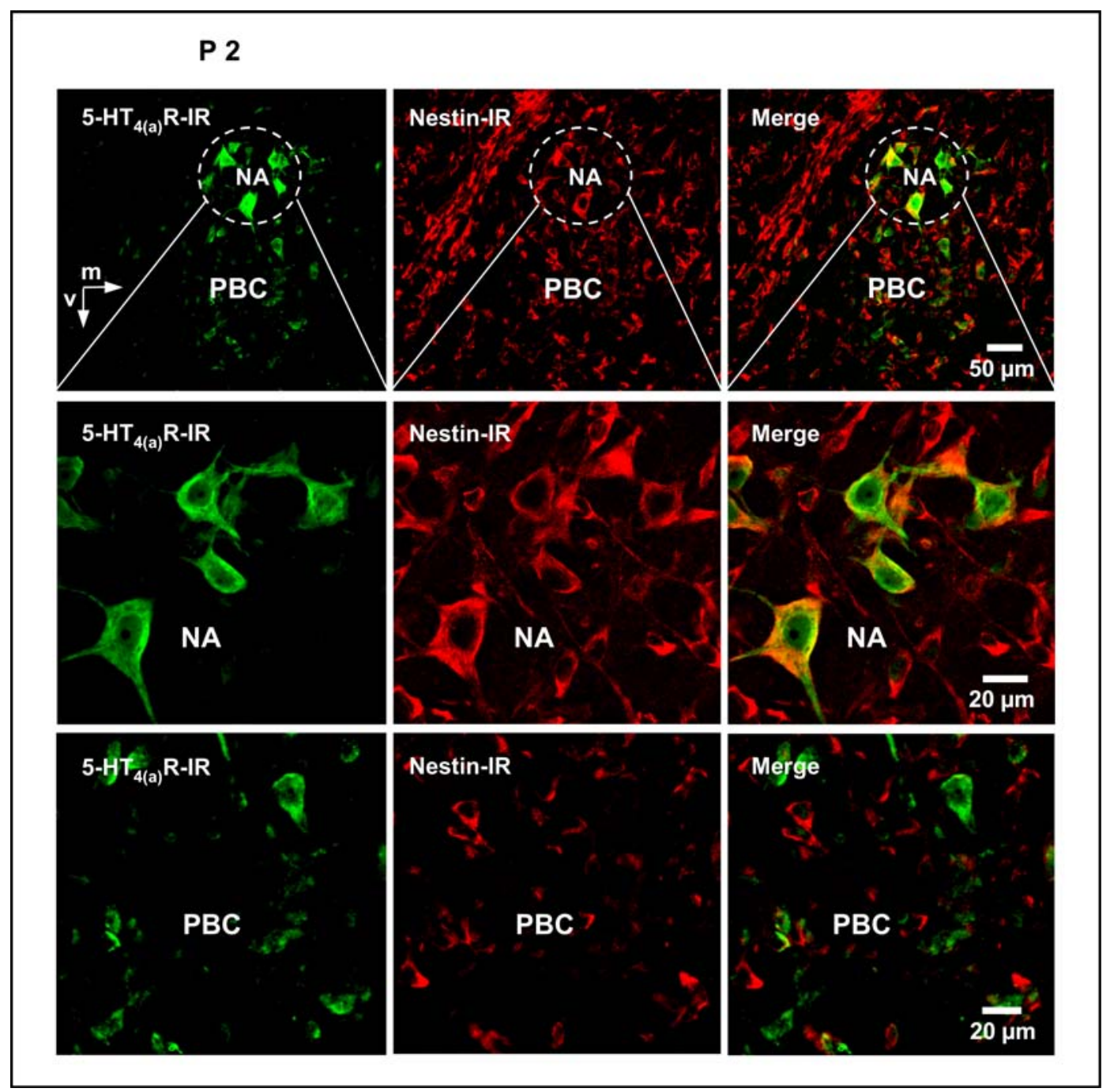

Figure 48. Double labelling of the 5- $\mathrm{HT}_{4(\mathrm{a})}$ receptor and the nestin protein: cells which expressed the 5- $\mathrm{HT}_{4(\mathrm{a})}$ receptor (Alexa 488, green colour) and the nestin protein (Alexa 647, red colour) were predominantly localised within the ambigual nucleus (NA). Cells localised within the neonatal PBC expressed only sporadically both proteins. Abbreviations: preBötzinger complex (PBC), ambigual nucleus (NA), immunoreactivity (IR), medial (m), ventral (v). 


\subsubsection{Characterisation of the nestin-immunoreactive cells using the glial fibrillary acidic protein (GFAP}

Due to the fact that the nestin immunoreactivity does not clearly distinguish between neuronal and glial progenitor cells [Messam et al. (2000)], double labellings of the nestin protein and the glial fibrillary acidic protein (GFAP), which is known to be a specific marker for astroglial cells [Privat et al. (1995), Shao and McCarthy (1994)], were performed (fig. 49). Sixty point eight per cent of the nestin-positive cells expressed the GFAP (515 of 847 cells, 2 slices containing the PBC of 3 different animals each), and $59.4 \%$ of the GFAP-positive cells expressed the nestin protein (515 of 867 cells, 2 slices containing the PBC of 3 different animals each) which indicated that the majority of nestin-immunoreactive cells were of the neuroglial type.

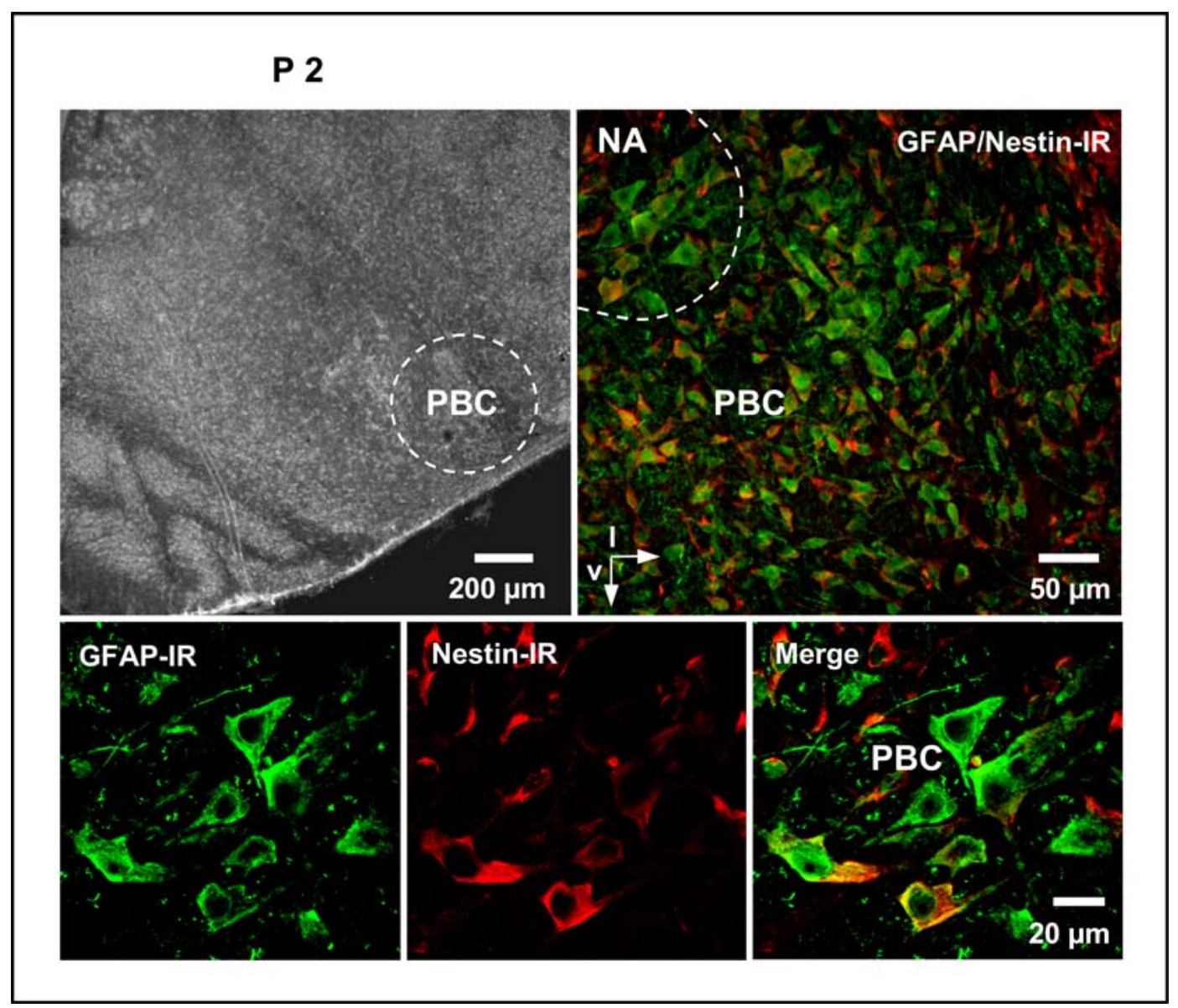

Figure 49. Double labelling of nestin and GFAP: to characterise the cell type of nestin-ir cells, a double labelling of nestin (Alexa 647, red colour) and GFAP (Alexa 488, green colour) was performed in which the glial fibrillary acidic protein (GFAP) was used as a marker for glial cells. Sixty point eight per cent of the nestin-ir cells expressed the GFAP (515 of 847 cells, two slices containing the PBC of three different animals each) and were therefore identified as glial cells. Abbreviations: glial fibrillary acidic protein (GFAP), preBötzinger complex (PBC), ambigual nucleus (NA), immunoreactivity (IR), immunoreactive (ir), lateral (I), ventral (v).

\subsubsection{Analysis of the $5-\mathrm{HT}_{4(\mathrm{a})}$ receptor expression in identified glial cells}

Since the 5- $\mathrm{HT}_{4(\mathrm{a})}$ receptor was sporadically expressed in nestin-immunoreactive cells as had previously been shown (3.3.5.2.), electrophysiologically identified astroglial cells [Grass et al. (2004)] within the neonatal PBC at the development stage P 2 were labelled intracellularly with biocytin in collaboration with Dr. Hülsmann, and then analysed for $5-\mathrm{HT}_{4(\mathrm{a})}$ receptor expression. 
The identified astroglial cells (6 cells from 6 different slice preparations) did not reveal any specific $5-\mathrm{HT}_{4(\mathrm{a})}$ receptor immunoreactivity suggesting that cells within the neonatal PBC expressing both the nestin protein and the $5-\mathrm{HT}_{4(\mathrm{a})}$ receptor were of the neural type.

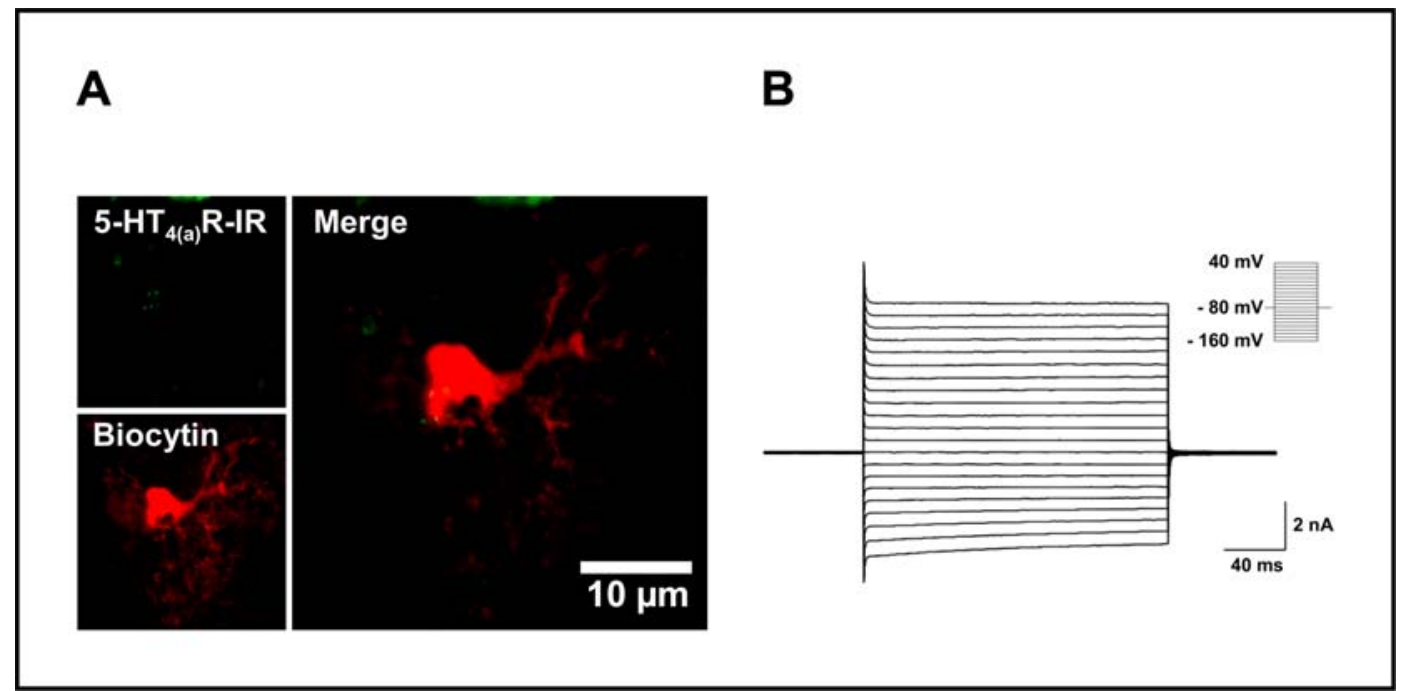

Figure 50. Analysis of the $5-\mathrm{HT}_{4(\mathrm{a})}$ receptor expression in identified neonatal glial cells: (A) shows an example of an astrocyte which was labelled intracellularly with biocytin (Texas red-conjugated avidin, red colour). The glial cell did not exhibit any $5-\mathrm{HT}_{4(\mathrm{a})}$ receptor immunoreactivity (Alexa 488, green colour). (B) The whole-cell voltage-clamp recording from a passive astrocyte within the preBötzinger complex is shown in which the whole-cell membrane currents were recorded by stepping the holding potential from -160 to $40 \mathrm{mV}$ (10 mV increments) starting at a holding potential of $-80 \mathrm{mV}$.

The 5- $\mathrm{HT}_{4(\mathrm{a})}$ receptor was expressed in neurones within the preBötzinger complex or its precursor structure during the development in which the most extensive immunoreactivity appeared at the development stage $\mathrm{E} 18$. The $\mu$-opioid and the $5-\mathrm{HT}_{4(\mathrm{a})}$ receptors were strongly co-expressed in neurones of the $\mathrm{PBC}$, whereas a $5-\mathrm{HT}_{4(\mathrm{a})}$ receptor expression in neurones within the dorsal horn was absent. Furthermore, the $5-\mathrm{HT}_{4(\mathrm{a})}$ receptor was expressed in identified embryonic respiratory neurones (E 19), whereas an expression in identified neonatal astroglial cells (P 2) was missed.

Nestin-immunoreactive (-ir) cells first appeared within the PBC at the development stage E 20, whereas nestin-ir cells were absent in cells of the ambigual nucleus and its ventral periphery at the development stage E 16. The number of nestin-ir cells increased directly after birth in which the majority of the these cells expressed the GFAP and were therefore classified as glial cells. Nestin-ir cells which expressed the $5-\mathrm{HT}_{4(\mathrm{a})}$ receptor were predominantly localised within the ambigual nucleus and appeared only sporadically within the PBC. 


\subsection{Expression and function of the serotonin $1 \mathrm{~A}$ and 7 receptor isoforms in the respiratory system}

The serotonin $1 \mathrm{~A}$ receptor isoform $\left(5-\mathrm{HT}_{1 \mathrm{~A}} \mathrm{R}\right)$ is the most extensively expressed receptor subtype in neurones within the central respiratory system. The direct application of agonists, e.g. 8-OH-DPAT, to cells depress the excitability of respiratory neurones [Bonham et al. (1995), Lalley et al. (1994a)]. The 5-HT ${ }_{1 A} R$ decreases the intracellular cyclic adenosine 5', 3'-monophosphate concentration ([CAMP $]_{i}$ ) [Barnes and Sharp (1999), Raymond et al. (1999)] as well as the $\mu$-opioid receptor ( $\mu$-OR). In contrast to the $5-\mathrm{HT}_{1 \mathrm{~A}} \mathrm{R}$ and $\mu-\mathrm{OR}$, the $5-\mathrm{HT}_{7} \mathrm{R}$ increases the [cAMP] . Therefore, it was analysed whether these receptors are co-expressed in neurones of the preBötzinger complex (PBC) and whether the systemic application of 8-OH-DPAT, which also activates the $5-\mathrm{HT}_{7} \mathrm{R}$, recovers the opioid-induced depression of the respiratory activity. Furthermore, it was analysed whether the opioid-induced analgesia persists.

\subsubsection{Expression of the $5-\mathrm{HT}_{1 A}, 5-\mathrm{HT}_{7}$, and $\mu$-opioid receptors in neurones within the PBC and the spinal cord}

The spatial expression of the $5-\mathrm{HT}_{1 \mathrm{~A}}$ and $5-\mathrm{HT}_{7}$ receptor isoforms in neurones within both the PBC and the cervical spinal cord (spinal segments C2 - C4) was analysed. Furthermore, it was investigated whether both receptors are co-expressed with the $\mu$ opioid receptor. The substance P-reactive neurokinin-1 (NK-1) receptor and the appearance of the principal nucleus of the inferior olive were used as markers for the anatomical identification of the PBC. As an additional control the expression pattern of the messenger RNA specific for the $5-\mathrm{HT}_{7}$ receptor was analysed in cells of the PBC using in-situ-hybridisation and compared with the $5-\mathrm{HT}_{7}$ receptor expression pattern on protein level using the monoclonal 5HT7R/220 antibody (see 3.1.2.).

Five slices containing the PBC of 5 different animals each were analysed for the 5$\mathrm{HT}_{1 \mathrm{~A}}, 5-\mathrm{HT}_{7}$, and $\mu$-opioid receptor expression in the same slice (fig. 51). In neurones of the PBC all three receptors were strongly co-expressed in which the $\mu$-OR-positive neurones expressed the $5-\mathrm{HT}_{1 \mathrm{~A}} \mathrm{R}$ at $86 \%$ (1080 of 1256 cells) and the $5-\mathrm{HT}_{7} \mathrm{R}$ at $78.5 \%$ (986 of 1256 cells). All neurones which expressed the $5-\mathrm{HT}_{7} \mathrm{R}$ were also 5$\mathrm{HT}_{1 \mathrm{~A}} \mathrm{R}$-immunoreactive.

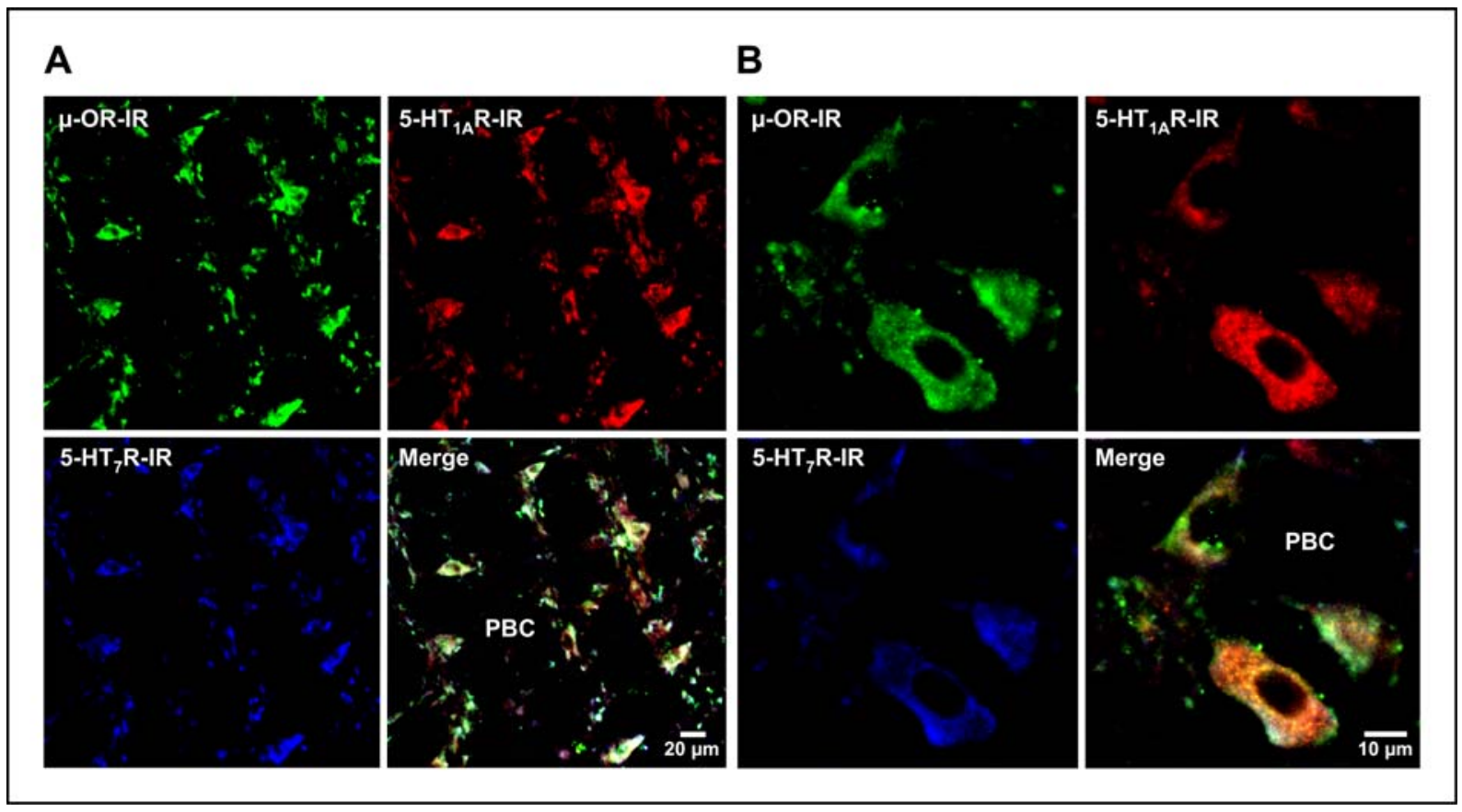


Figure 51. Triple labelling of $\mu$-opioid, 5-HT $1 \mathrm{~A}$, and $5-\mathrm{HT}_{7}$ receptors in neurones within the PBC: forty-micrometre-thick slices at the level of the PBC were stained with the anti- $\mu$-opioid receptor $(\mu$ $\mathrm{OR}$ ) antibody from goat, the anti-5- $\mathrm{HT}_{1 \mathrm{~A}}$ antibody from guinea pig, and the monoclonal anti-5- $\mathrm{HT}_{7}$ receptor antibody from Syrian hamster (clone 5HT7R/220) followed by appropriate fluorochrome-conjugated secondary antibodies [ $\mu$-OR (Alexa 488, green colour), 5- $\mathrm{HT}_{1 \mathrm{~A}} \mathrm{R}$ (Alexa 555, red colour), and $5-\mathrm{HT}_{7} \mathrm{R}$ (Cy5, blue colour)]. (A) All three receptors were strongly co-expressed in neurones of the $\mathrm{PBC}$. (B) indicates the co-expression in neurones at a higher magnification. Abbreviations: preBötzinger complex (PBC), immunoreactivity (IR).

The analysis of neurones within the spinal cord (spinal segments C2 - C4, 5 slices of 5 different animals each for the corresponding spinal segment) indicated a strong coexpression of the $5-\mathrm{HT}_{1 \mathrm{~A}}, 5-\mathrm{HT}_{7}$, and $\mu$-opioid receptors in neurones of the ventral horn which served as a positive control (fig. 52A). The neurones of the dorsal horn showed also a co-immunoreactivity for all three receptors, but the $5-\mathrm{HT}_{7}$ receptor isoform was less expressed (fig. 52B).

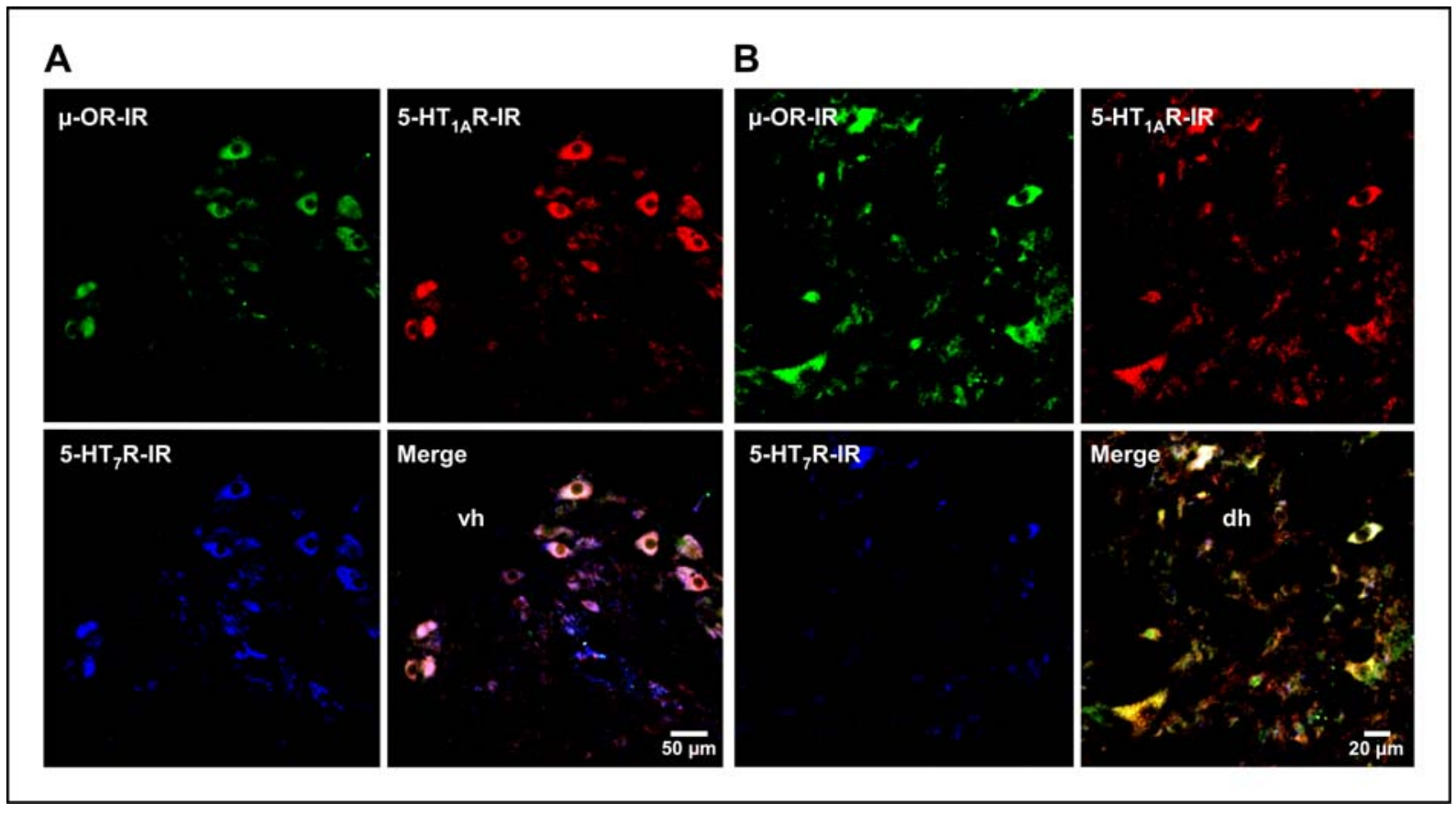

Figure 52. Triple labelling of $\mu$-opioid, $5-\mathrm{HT}_{1 \mathrm{~A}}$, and $5-\mathrm{HT}_{7}$ receptors in neurones within the cervical spinal cord: (A) shows an example (spinal segment C3/C4) for the $\mu$-opioid (Alexa 488, green colour), 5- $\mathrm{HT}_{1 \mathrm{~A}}$ (Alexa 555, red colour), and 5- $\mathrm{HT}_{7}$ receptor (Cy5, blue colour) expression in neurones of the ventral horn which served as a positive control. (B) The $5-\mathrm{HT}_{1 \mathrm{~A}}, 5-\mathrm{HT}_{7}$, and $\mu$-opioid receptors were co-expressed in neurones of the dorsal horn. In comparison with the $\mu$-opioid and 5$\mathrm{HT}_{1 \mathrm{~A}}$ receptors the $5-\mathrm{HT}_{7}$ receptor was less expressed. Abbreviations: ventral horn (vh), dorsal horn (dh), immunoreactive (ir), immunoreactivity (IR). 
The in-situ-hybridisation experiments (20 slices from 5 different animals each) demonstrated the strong expression of the $5-\mathrm{HT}_{7}$ receptor on RNA level in neurones of the preBötzinger complex (fig. 53) which was in accordance with analyses of the receptor expression on protein level using both the polyclonal and monoclonal anti-5$\mathrm{HT}_{7} \mathrm{R}$ antibodies in which the $5-\mathrm{HT}_{7} \mathrm{R}$ antibody-dependent immunoreactivity patterns for both antibodies were nearly identical.

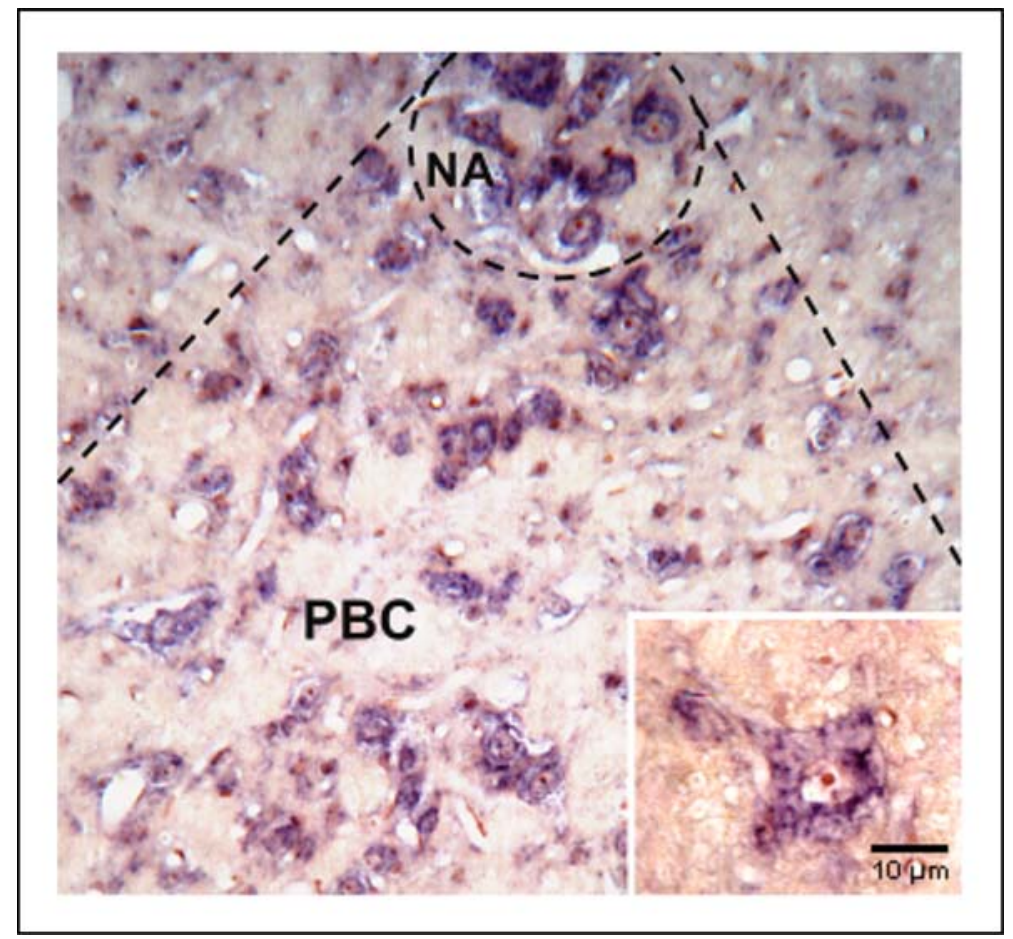

Figure 53. Messenger RNA expression specific for the serotonin 7 receptor in neurones of the preBötzinger complex: the expression of the $5-\mathrm{HT}_{7} \mathrm{R}$-specific mRNA in neurones of the preBötzinger complex (PBC) was shown using in-situ-hybridisation. Ten-micrometre-thick paraffin sections were applied with the $5-\mathrm{HT}_{7} \mathrm{R}$-specific antisense-probe (see 2.2.5.3.5.) in which samples which had been treated with the sense-probe served as negative controls. The sections were counterstained with Kernechtrot $\left(\right.$ Certistain $\left.^{\circledR}\right)$ to visualise the cell nuclei (red colour). The neurones within the PBC and the ambigual nucleus (NA) revealed a strong $5-\mathrm{HT}_{7}$ receptor-specific mRNA expression (blue colour). The inset shows a single neurone at a higher magnification which expressed the 5- $\mathrm{HT}_{7} \mathrm{R}$-specific mRNA.

\subsubsection{Expression of the $5-\mathrm{HT}_{1 \mathrm{~A}}$ and $5-\mathrm{HT}_{7}$ receptor-specific mRNA in identified respiratory neurones}

For the verification of the mRNA expression specific for the $5-\mathrm{HT}_{1 \mathrm{~A}}, 5-\mathrm{HT}_{7}$, and $\mu$ opioid receptors in identified respiratory neurones, single-cell RT-PCR analyses in collaboration with Dr. Haller and Dr. Ponimaskin were performed on the cytosol which had been harvested from electrophysiologically identified inspiratory neurones in the rhythmically active slice preparation. 


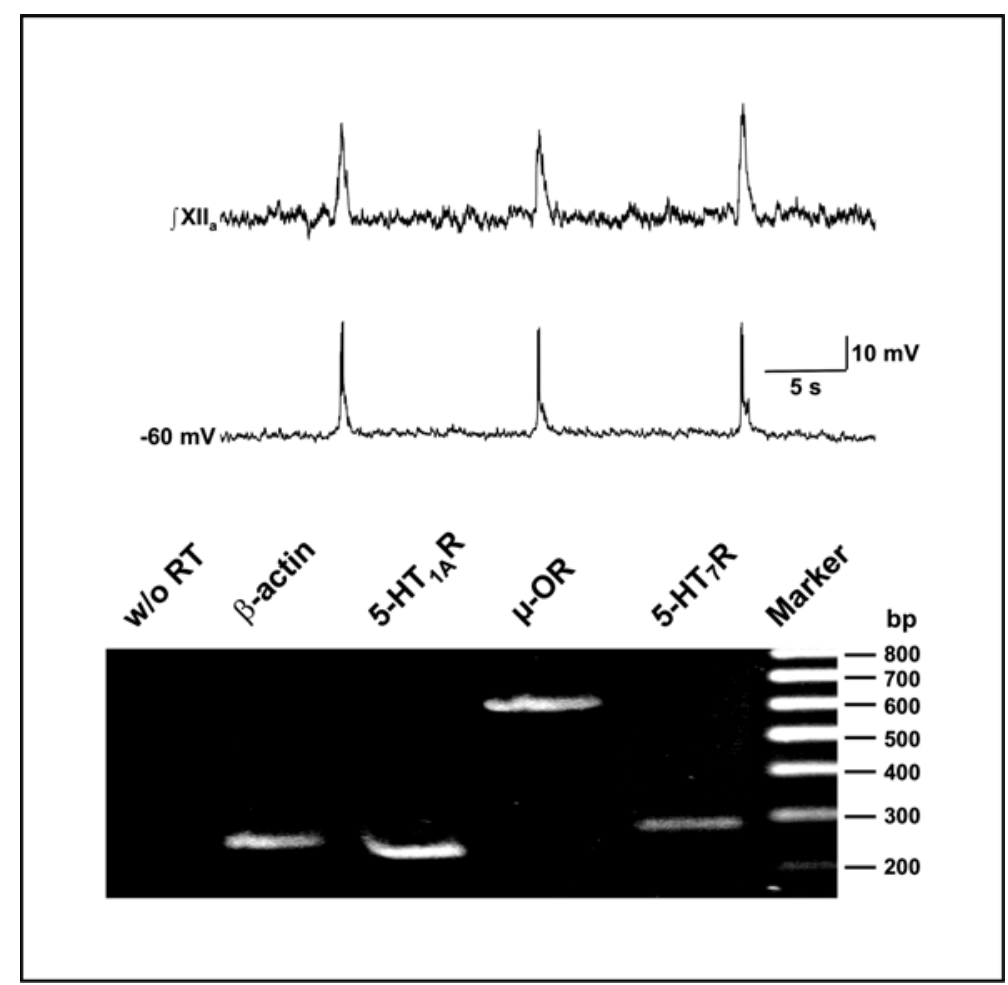

Figure 54. Messenger RNA expression specific for the $5-\mathrm{HT}_{1 \mathrm{~A}}, 5-\mathrm{HT}_{7}$, and $\mu$-opioid receptors in identified inspiratory neurones: on the top: the integrated hypoglossal nerve activity $\left(\int \mathrm{XII}_{\mathrm{a}}\right)$ corresponded to the rhythmic depolarisations of the membrane potential of a single inspiratory neurone which had been recorded in the whole-cell configuration (current clamp mode). At the bottom panel: single-cell RT-PCR analysis of an identified inspiratory neurone: the amplification products specific for the $5-\mathrm{HT}_{1 \mathrm{~A}}, 5-\mathrm{HT}_{7}$, and $\mu$-opioid receptors indicated their expression on RNA level in the identified neurones. Samples without reverse transcriptase (w/o RT) served as negative controls. The 'housekeeping gene` $\beta$-actin was used as an internal standard. All amplification products were partially sequenced for their identification.

The RT-PCR analysis of the identified inspiratory neurones revealed the expression of the mRNA specific for the 5- $\mathrm{HT}_{1 \mathrm{~A}}$ (9 of 10 cells from 10 different slice preparations), $5-\mathrm{HT}_{7}$ (10 of 10 cells from 10 different slice preparations), and $\mu$-opioid receptors (16 of 16 cells from 16 different slice preparations).

\subsubsection{Activation of the respiratory activity by systemic application of $8-\mathrm{OH}$ - DPAT}

In collaboration with Dr. Dutschmann the effects on the breathing pattern due to a systemic application of $8-\mathrm{OH}-\mathrm{DPAT}$, which is known as a selective $5-\mathrm{HT}_{1 \mathrm{~A}}$ receptor and partial 5- $\mathrm{HT}_{7}$ receptor agonist, were analysed in anaesthetised Sprague-Dawley rats $(200-250 \mathrm{~g}$, pentobarbital $60 \mathrm{mg} / \mathrm{kg}$, see 2.2.6.2.). The pentobarbital anaesthesia was necessary for the implantation of the femoral vein- and tracheal-catheter.

The application $(\mathrm{n}=5)$ of 8 -OH-DPAT $(100 \mu \mathrm{g} / \mathrm{kg})$ increased the respiratory minute volume (RMV) from $58.2 \pm 8.4 \mathrm{ml}$ to $109.3 \pm 9.2 \mathrm{ml}(\mathrm{p} \leq 0.01)$. The subsequent injection of the 5- $\mathrm{HT}_{1 \mathrm{~A}}$ receptor antagonist WAY $100635(1 \mathrm{mg} / \mathrm{kg}, \mathrm{n}=3)$ blocked these effects and the breathing activity returned to baseline levels $(64.5 \pm 12.1 \mathrm{ml} p \leq$ 0.05) (fig. 55). The injection of WAY 100635 alone did not have a significant effect on the baseline breathing (RMV: $84.1 \pm 7.1 \mathrm{ml}$ compared to the control of $75.1 \pm 7.0 \mathrm{ml}$, n. s.), and the subsequent injection of 8-OH-DPAT evoked no stimulating effects (RMV: $65.0 \pm 6.5 \mathrm{ml}$ compared to the control of $75.1 \pm 7.0 \mathrm{ml}, \mathrm{n} . \mathrm{s}$.). 
In contrast, after the intravenous injection of the antagonist SB 269970, specific for the $5-\mathrm{HT}_{7}$ receptor, the systemic application of 8-OH-DPAT still increased the RMV from $62.9 \pm 17.0 \mathrm{ml}$ to $97.3 \pm 24.5 \mathrm{ml}(p \leq 0.05)$.

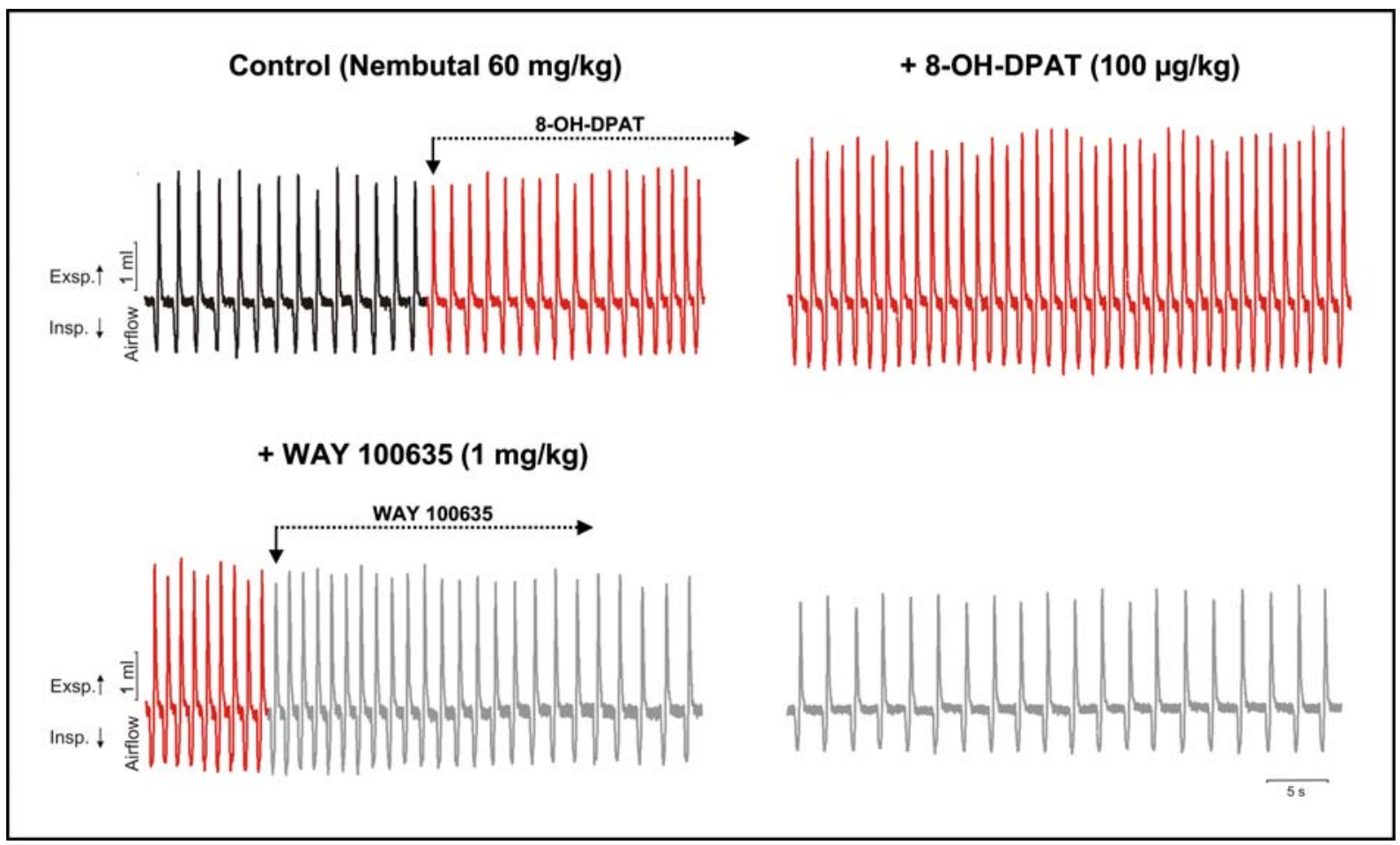

Figure 55. Acceleration of the respiratory activity by application of 8-OH-DPAT: the systemic application $(n=5)$ of $8-O H-D P A T(100 \mu \mathrm{g} / \mathrm{kg})$ [red trace] increased the RMV from $58.2 \pm 8.4 \mathrm{ml}$ to $109.3 \pm 9.2 \mathrm{ml}$ which was blocked by a subsequent application of $1 \mathrm{mg} / \mathrm{kg}$ WAY $100635(\mathrm{n}=3)$ [grey trace]. The black trace represents the respiratory activity under pentobarbital anaesthesia $(60 \mathrm{mg} / \mathrm{kg})$.

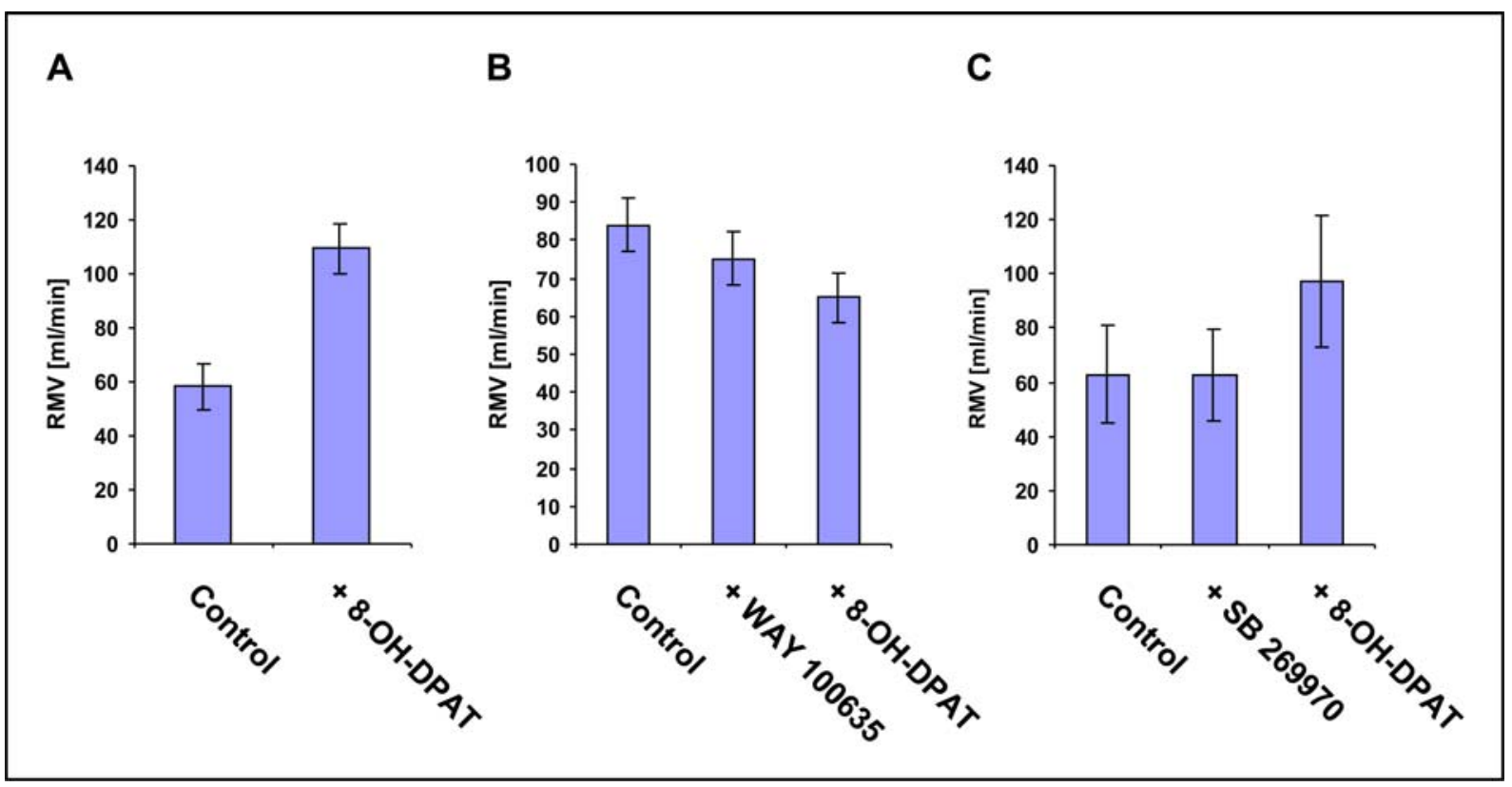

Figure 56. The histograms show in $(A)$ the significant acceleration of the respiratory activity caused by 8-OH-DPAT, in (B) the specific blockade of the 8-OH-DPAT effect by WAY 100635, and in (C) the significant stimulating effect of 8-OH-DPAT after the specific blockade of the serotonin 7 receptor isoform using SB 269970. 


\subsubsection{Compensation of the fentanyl-induced depression of the respiratory activity by 8-OH-DPAT}

Due to the excitatory effects of 8-OH-DPAT on the breathing activity, it was analysed whether 8-OH-DPAT recovers the opioid-induced depression of the respiratory activity.

The systemic application of $8-\mathrm{OH}$-DPAT $(100 \mu \mathrm{g} / \mathrm{kg})$ significantly increased the respiratory minute volume (RMV) as had previously been shown. The subsequent application of the $\mu$-opioid receptor agonist fentanyl $(10-15 \mu \mathrm{g} / \mathrm{kg}$ ) led to apnoea (RMV: $0.0 \pm 0.0 \mathrm{ml}$ in comparison with the control of $68.2 \pm 6.3 \mathrm{ml}, \mathrm{p}<0.001, \mathrm{n}=6$ ) in which the tail-flick response (TFR) was abolished. When the tail-flick latency was exceeding $300 \%$ of the baseline, the heat stimulus was immediately stopped. This was defined as a complete tail-flick response abolishment (see 2.2.6.2.).

The respiratory activity recovered within 2 - 3 min after the application of 8-OH-DPAT (RMV: $21.2 \pm 4.1 \mathrm{ml}, \mathrm{p}<0.001$ ) and returned within the next $3 \mathrm{~min}$ almost to the baseline activity (RMV: $59.7 \pm 2.5 \mathrm{ml}$ compared to the control of $68.2 \pm 6.3 \mathrm{ml}, \mathrm{p}<$ $0.001)$, whereas the TFR was still abolished. The additional application of the $\mu$ opioid receptor antagonist naloxone $(1 \mathrm{mg} / \mathrm{kg})$ further increased the RMV to control levels in which the TFR was re-established. In comparison with the control, the TFR was prolonged in 2 of 6 experiments (n. s.) (fig. 57). 
A

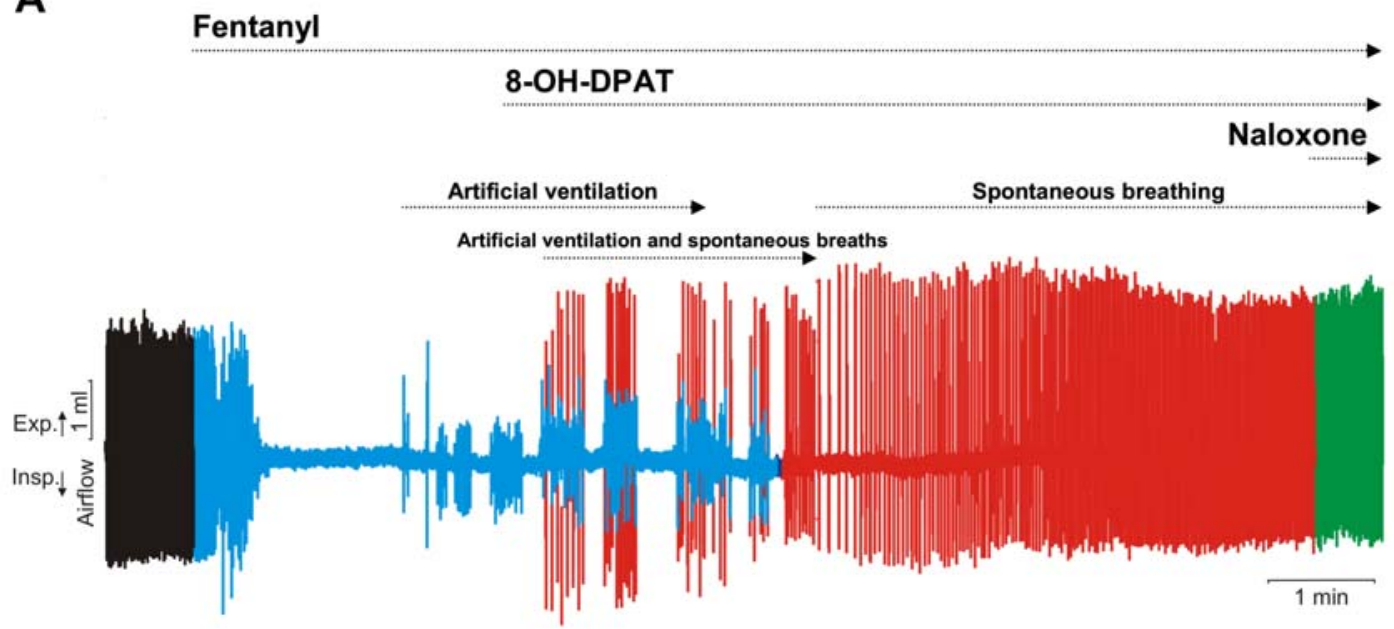

B

Control (Nembutal $60 \mathrm{mg} / \mathrm{kg}$ )

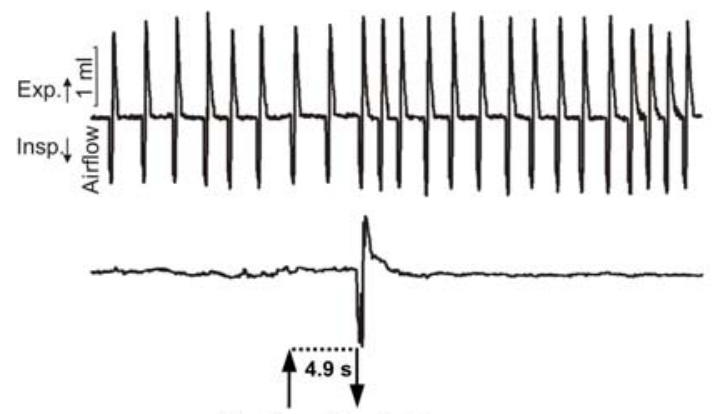

Heat on Heat off

D

+ 8-OH-DPAT $(100 \mu \mathrm{g} / \mathrm{kg})$

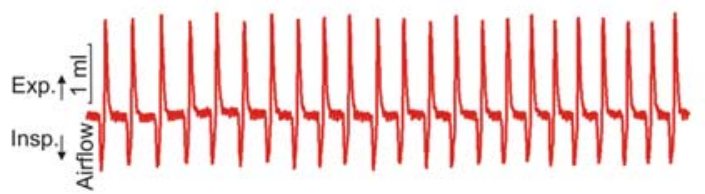

$\uparrow$ Tail flick abolished $\downarrow$

Heat on
Heat off
C + Fentanyl $(10 \mu \mathrm{g} / \mathrm{kg})$
E
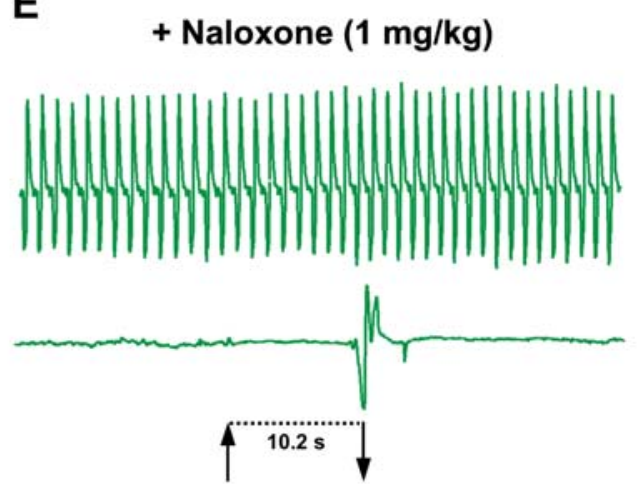

Heat on Heat off

Figure 57. Compensation of the fentanyl-induced depression of breathing by application of 8OH-DPAT without loss of the analgetic effects of fentanyl:

(A) overview of the response in one of the in-vivo experiments.

(B) shows the respiratory airflow of an anaesthetised, spontaneous-breathing in-vivo rat under pentobarbital application $(60 \mathrm{mg} / \mathrm{kg}$ ) (black trace). In the control conditions, a TFR was obtained after a short latency (4.9 s).

(C) the application of $10-15 \mu \mathrm{g} / \mathrm{kg}$ fentanyl (blue trace) induced apnoea (RMV: $0.0 \pm 0.0 \mathrm{ml}$ in comparison with the control of $68.2 \pm 6.3 \mathrm{ml}$ ). The TFR was completely abolished after the application of the $\mu$-opioid receptor agonist fentanyl. 
(D) the consecutive application of $100 \mu \mathrm{g} / \mathrm{kg}$ of 8-OH-DPAT (red trace) prevailed over the reduction of the RMV induced by fentanyl and restored a stable breathing with RMV recovering to $59.7 \pm 2.5 \mathrm{ml}$. The analgetic response remained unchanged.

(E) application of $1 \mathrm{mg} / \mathrm{kg}$ of the $\mu$-opioid receptor antagonist naloxone (green trace) re-established both the respiratory activity to the control level and the TFR which was prolonged (10.2 s) in comparison with the control (4.9 s) in 2 of 6 experiments (n. s.). Abbreviations: expiration (Exp.), inspiration (Insp.), spontaneous breathing (s), respiratory minute volume (RMV), tail-flick response (TFR).

A

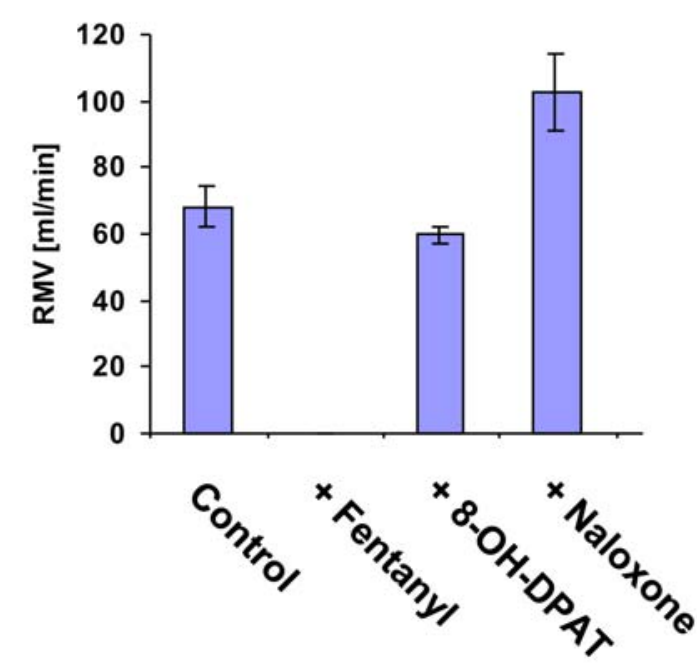

B

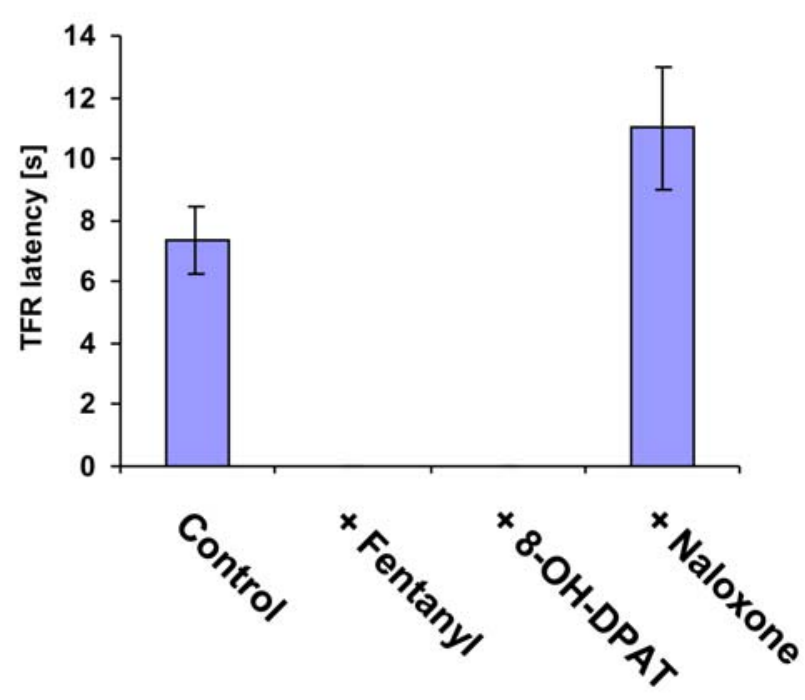

Figure 58. The histograms show in $(A)$ the significance of the recovery of the fentanyl-induced depression of the respiratory activity caused by 8-OH-DPAT and in (B) the maintenance of the fentanylinduced tail-flick abolishment under 8-OH-DPAT and its significant re-establishment after naloxone application.

Although the serotonin 7 receptor isoform $\left(5-\mathrm{HT}_{7} \mathrm{R}\right)$ was abundantly expressed in neurones of the preBötzinger complex which had been verified on RNA- and proteinlevel, the in-vivo experiments using a fully intact animal model indicated that there were no significant systemic effects on the breathing pattern due to a $5-\mathrm{HT}_{7}$ receptor activation.

On the one hand, the antagonist WAY 100635, specific for the 5- $\mathrm{HT}_{1 \mathrm{~A}}$ receptor, inhibited the 8-OH-DPAT-induced acceleration of the respiratory activity and, on the other hand, after application of the antagonist SB 2699708, specific for the $5-\mathrm{HT}_{7}$ receptor, 8-OH-DPAT still increased the respiratory activity. These experiments demonstrated that the stimulation of the respiratory activity by 8-OH-DPAT was mainly mediated through the activation of the $5-\mathrm{HT}_{1 \mathrm{~A}}$ receptor isoform.

Even though the $5-\mathrm{HT}_{1 \mathrm{~A}} \mathrm{R}$ and the $\mu$-OR decrease the $[\mathrm{CAMP}]_{\mathrm{i}}$, the opioid-induced depression of the respiratory activity was compensated by systemic application of 8$\mathrm{OH}$-DPAT, while the analgetic effects of the $\mu$-opioid receptor agonist fentanyl were not affected. The recovery of the respiratory activity by activation of the $5-H T_{1 A} R$ suggest a more complex network effect (see discussion part 4.3.). 


\subsection{Expression and function of the serotonin $2 A$ and $2 B$ receptor isoforms in the respiratory system}

The selective activation of serotonin receptors which stimulate $\left(5-\mathrm{HT}_{4(\mathrm{a})} \mathrm{R}\right)$ or inhibit $\left(5-\mathrm{HT}_{1 \mathrm{~A}} \mathrm{R}\right)$ the activity of the adenylyl cyclase $(\mathrm{AC})$ resulting in an increase or decrease of the intracellular cyclic adenosine $5^{\prime}, 3^{\prime}$-monophosphate ([cAMP] $]_{i}$ ) compensated the depression of the respiratory activity caused by selective activation of $\mu$ opioid receptors ( $\mu$-OR) as had previously been shown (see 3.2.3. and 3.4.4.). The $\mu-$ OR are negatively coupled to the $A C$ and decrease the [CAMP] $]_{\text {. }}$

The serotonin $2 \mathrm{~A}$ and $2 \mathrm{~B}$ receptor isoforms $\left(5-\mathrm{HT}_{2 \mathrm{~A}} \mathrm{R}\right.$ and $\left.5-\mathrm{HT}_{2 \mathrm{~B}} \mathrm{R}\right)$ operate on $\mathrm{a}$ different signal transduction pathway. Both receptors stimulate the phospholipase $C$ (PLC) which finally results in an activation of the protein kinase $C$ (PKC). Earlier studies demonstrated the PKC pathway-mediated modulation of the respiratory pattern [Haji et al. (1996)] and excitation of respiratory neurones by activation of 5$\mathrm{HT}_{2 \mathrm{~A}}$ receptors [Lalley et al. (1995), Onimaru et al. (1998)].

In this study, it was investigated whether the $5-\mathrm{HT}_{2 \mathrm{~B}} \mathrm{R}$ is expressed in neurones of the preBötzinger complex (PBC) and whether the 5- $\mathrm{HT}_{2 \mathrm{~A}}$ and $5-\mathrm{HT}_{2 \mathrm{~B}}$ receptors, which both operate on the same signal transduction pathway, are co-expressed. Furthermore, the potentially stimulating effects on respiratory activity and the compensation of opioid-induced depression of the respiratory activity through selective receptor activation in a fully intact animal model was tested for both receptors.

\subsubsection{Expression of the $5-\mathrm{HT}_{2 \mathrm{~A}}$ and $5-\mathrm{HT}_{2 \mathrm{~B}}$ receptors in neurones within the PBC}

To analyse the expression of the $5-\mathrm{HT}_{2 \mathrm{~A}} \mathrm{R}$ and $5-\mathrm{HT}_{2 \mathrm{~B}} \mathrm{R}$ on RNA level, the PBC was dissected from the slice preparation. The mRNA specific for the $5-\mathrm{HT}_{2 \mathrm{~A}}$ and $5-\mathrm{HT}_{2 \mathrm{~B}}$ receptors were detectable (fig. 59). As a control, 3 different development stages ( $P 1$, $P$ 10, and $P$ 25) were selected for the analysis ( $n=3$ in which the patches of both sides of each slice from 2 different animals were combined for one sample).

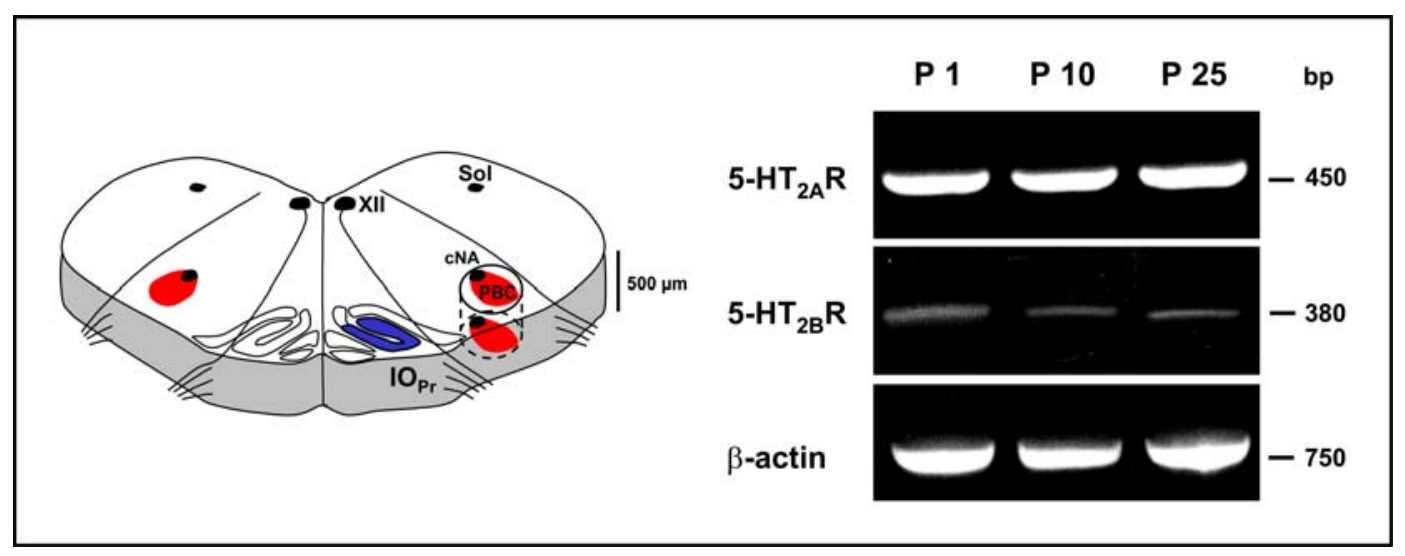

Figure 59. RT-PCR analysis of the expression of the 5- $\mathrm{HT}_{2 \mathrm{~A}}$ and $5-\mathrm{HT}_{2 \mathrm{~B}}$ receptor-specific mRNA in the PBC: the specific mRNA of both receptor isoforms were detectable in the PBC. Samples without reverse transcriptase served as negative controls. The 'housekeeping gene` $\beta$-actin was used as an internal standard. All amplification products were partially sequenced for their identification. On the left side, a schematic representation of the dissected region is shown. Abbreviations: preBötzinger complex (PBC), nucleus solitary tract (Sol), nucleus ambiguus pars compacta (cNA), hypoglossal nucleus (XII), principal nucleus of the inferior olive $\left(\mathrm{IO}_{\mathrm{Pr}}\right)$. 
The polyclonal monospecific anti-5- $\mathrm{HT}_{2 \mathrm{~B}} \mathrm{R}$ antibody from rabbit (see 3.1.1.4.3.) was used to analyse the spatial $5-\mathrm{HT}_{2 \mathrm{~B}} \mathrm{R}$ expression on protein level in neurones of the $\mathrm{PBC}$. To verify the expression of the $5-\mathrm{HT}_{2 \mathrm{~B}} \mathrm{R}$ in $\mathrm{PBC}$ neurones, double labellings of the $5-\mathrm{HT}_{2 \mathrm{~B}}$ and $\mathrm{NK}-1$ receptors were performed (fig. 60). The immunohistochemistry revealed the $5-\mathrm{HT}_{2 \mathrm{~B}} \mathrm{R}$ expression on protein level in the $\mathrm{PBC}$.

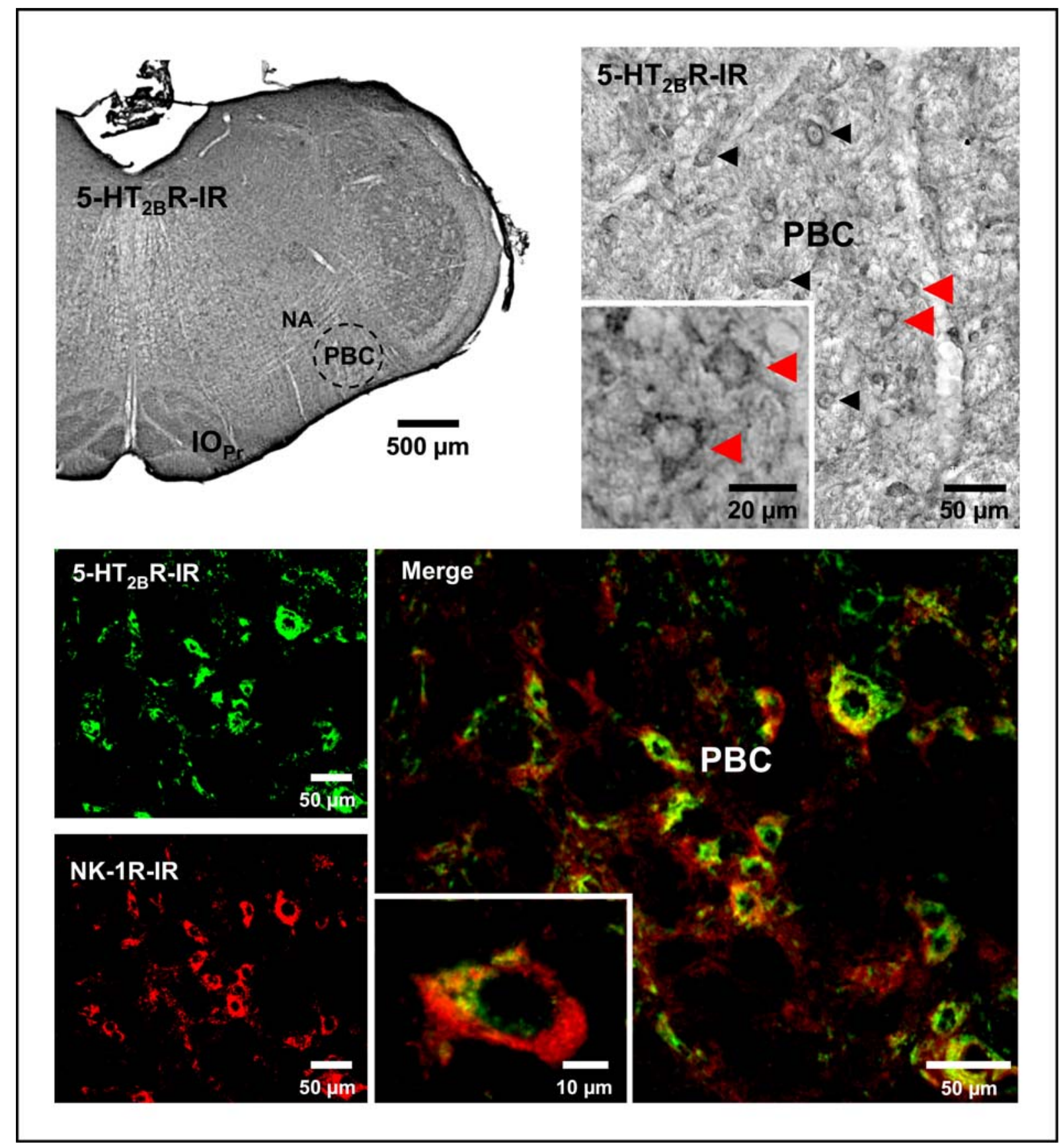

Figure 60. Expression of the 5- $\mathrm{HT}_{2 \mathrm{~B}}$ receptor isoform in neurones of the PBC: on the top: a 5$\mathrm{HT}_{2 \mathrm{~B}}$ receptor staining in neurones of the $\mathrm{PBC}$ is shown in which DAB was used as a chromogen (PAP method). The labelling indicated the expression of the 5- $\mathrm{HT}_{2 \mathrm{~B}}$ receptor isoform in the PBC which was identified by the appearance of the principal nucleus of the inferior olive (overview on the left side). At the bottom panel: the Substance P-reactive neurokinin-1 receptor (Alexa 555, red colour) which has been proposed as a potential marker for the $\mathrm{PBC}$ was used to confirm the 5- $\mathrm{HT}_{2 \mathrm{~B}}$ receptor expression in the PBC. The double labelling demonstrated the expression of the $5-\mathrm{HT}_{2 \mathrm{~B}}$ receptor isoform (Alexa 488, green colour) in PBC neurones. Abbreviations: ambigual nucleus (NA), preBötzinger complex (PBC), principal nucleus of the inferior olive $\left(\mathrm{IO}_{\mathrm{Pr}}\right)$, immunoreactivity (IR). 
Furthermore, it was investigated whether the $5-\mathrm{HT}_{2 \mathrm{~B}}$ and $5-\mathrm{HT}_{2 \mathrm{~A}}$ receptor isoforms are co-expressed. The double labelling of the $5-\mathrm{HT}_{2 \mathrm{~B}}$ and $5-\mathrm{HT}_{2 \mathrm{~A}}$ receptors showed that both receptors were strongly co-expressed in which all $5-\mathrm{HT}_{2 \mathrm{~B}} \mathrm{R}$-immunoreactive neurones within the PBC were also 5- $\mathrm{HT}_{2 \mathrm{~A}} \mathrm{R}$-positive (fig. 61).

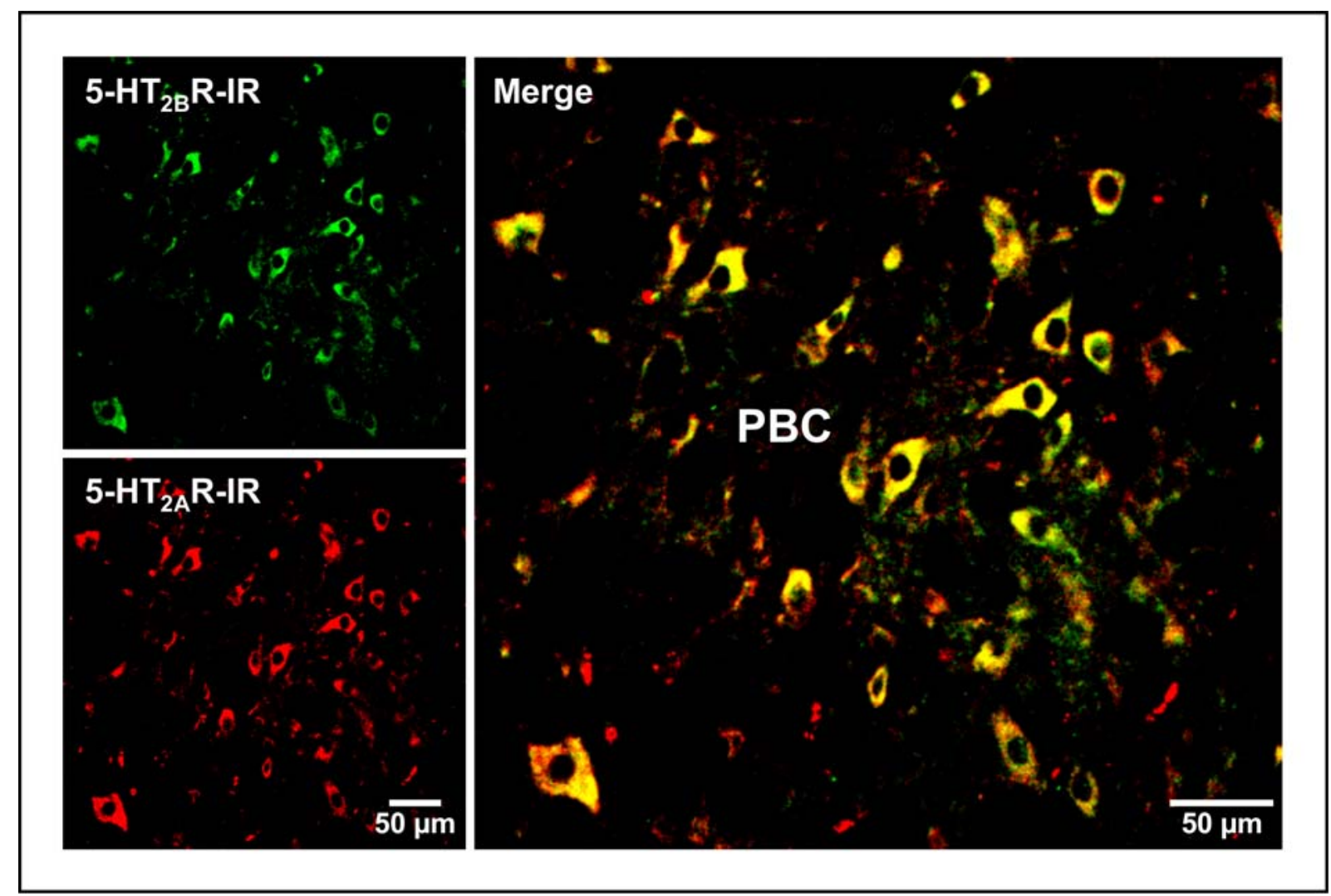

Figure 61. Double labelling of the serotonin 2A and 2B receptor isoforms: the 5-HT $2 A$ (Alexa 647 , red colour) and the $5-\mathrm{HT}_{2 \mathrm{~B}} \mathrm{R}$ (Cy2, green colour) were strongly co-expressed in neurones within the preBötzinger complex (PBC) in which all $5-\mathrm{HT}_{2 \mathrm{~B}} \mathrm{R}$-immunoreactive neurones were also $5-\mathrm{HT}_{2 \mathrm{~A}} \mathrm{R}-$ positive.

\subsubsection{In-vivo analysis of systemic effects of the $5-\mathrm{HT}_{2 \mathrm{~A}}$ and $5-\mathrm{HT}_{2 \mathrm{~A}}$ receptors on the breathing pattern}

The effects of intravenous (i. v.) application of the agonists and antagonists for the 5$\mathrm{HT}_{2 \mathrm{~A}}$ ( $\alpha$-methyl-5-HT or Ketanserin) and 5- $\mathrm{HT}_{2 \mathrm{~B}}$ (BW $723 \mathrm{C} 86$ or LY 272015) receptor isoforms on spontaneous breathing activity were investigated in anaesthetised (pentobarbital $60 \mathrm{mg} / \mathrm{kg}$ ) Sprague-Dawley rats $(200-250 \mathrm{~g}$ ) in collaboration with Dr. Dutschmann. Furthermore, it was tested whether these agonists are suitable to recover the fentanyl-induced depression of the respiratory activity, as it was previously shown for the $5-\mathrm{HT}_{4(\mathrm{a})}$ and $5-\mathrm{HT}_{1 \mathrm{~A}}$ receptor isoforms (see 3.2.4. or 3.4.4.). For the measurement of the blood pressure, the experimental set-up was augmented with an additional MacLab-linked pressure transducer which was connected to a femoral artery catheter (see 2.2.6.2.). 
The systemic application of the $5-\mathrm{HT}_{2 \mathrm{~A}}$ receptor agonist $\alpha$-methyl-5-HT $(100 \mu \mathrm{g} / \mathrm{kg})$ caused a transient respiratory depression which was indicated by a decrease in the respiratory minute volume (RMV) from $80.8 \pm 9.2 \mathrm{ml}$ to $18.4 \pm 8.4 \mathrm{ml}(p<0.01)$. The respiratory depression was accompanied by a pronounced increase in the mean arterial pressure (MAP: $110.3 \pm 10.3 \mathrm{mmHg}$ in comparison with the control of $76.7 \pm$ $3.9 \mathrm{mmHg}, \mathrm{p}<0.05)$. Two min after the injection the RMV remained suppressed $(44.4 \pm 19.7 \mathrm{ml})$, while the MAP transiently returned to baseline values $(78.3 \pm 8.3$ $\mathrm{mmHg})$. After $4 \mathrm{~min}$ the RMV recovered $(75.2 \pm 13.6 \mathrm{ml})$ and the MAP was permanently decreased in comparison with the control $(54.3 \pm 4.7 \mathrm{mmHg}, \mathrm{p}<0.05)$ resulting in a hypotonia lasting for 20 - 30 min (fig. 62A).

The injection of the $5-\mathrm{HT}_{2 \mathrm{~A}}$ receptor antagonist Ketanserin $(1 \mathrm{mg} / \mathrm{kg})$ caused a transient respiratory depression (RMV: $63.0 \pm 12.1 \mathrm{ml}$ compared to the control of $77.8 \pm 10.2 \mathrm{ml}, \mathrm{n}$. s.) which recovered quickly to baseline $(72.2 \pm 6.0 \mathrm{ml})$, while a decrease in the MAP $(68.0 \pm 11.5 \mathrm{mmHg}$ compared to the control of $83.3 \pm 7.6 \mathrm{mmHg}$ ) was observed (fig. 62B).

As a control for the transient effects, the same amount of saline was injected which had no effects.

Both the injection of the $5-\mathrm{HT}_{2 B}$ receptor agonist BW $723 \mathrm{C} 86(1 \mathrm{mg} / \mathrm{kg})$ and the antagonist LY $272015(1 \mathrm{mg} / \mathrm{kg})$ caused neither a transient nor a persistent change of the breathing pattern and the MAP.

Furthermore, it was tested whether the 5- $\mathrm{HT}$ receptor agonists for the $2 \mathrm{~A}$ and $2 \mathrm{~B}$ isoforms potentially recover the fentanyl-induced respiratory depression. However, all attempts failed and the i. v. injection of the $5-\mathrm{HT}_{2 \mathrm{~A}}$ receptor agonist $\alpha$-methyl-5-HT or the $5-\mathrm{HT}_{2 \mathrm{~B}}$ receptor agonist BW $723 \mathrm{C} 86$ had no effects.

These data suggest that selective activation of the $5-\mathrm{HT}_{2 \mathrm{~A}}$ or $5-\mathrm{HT}_{2 \mathrm{~B}}$ receptor isoforms did not have significantly longer-lasting systemic effects on breathing pattern although both receptor isoforms are expressed in neurones of the preBötzinger complex as was previously shown (see 3.5.1.). 
A
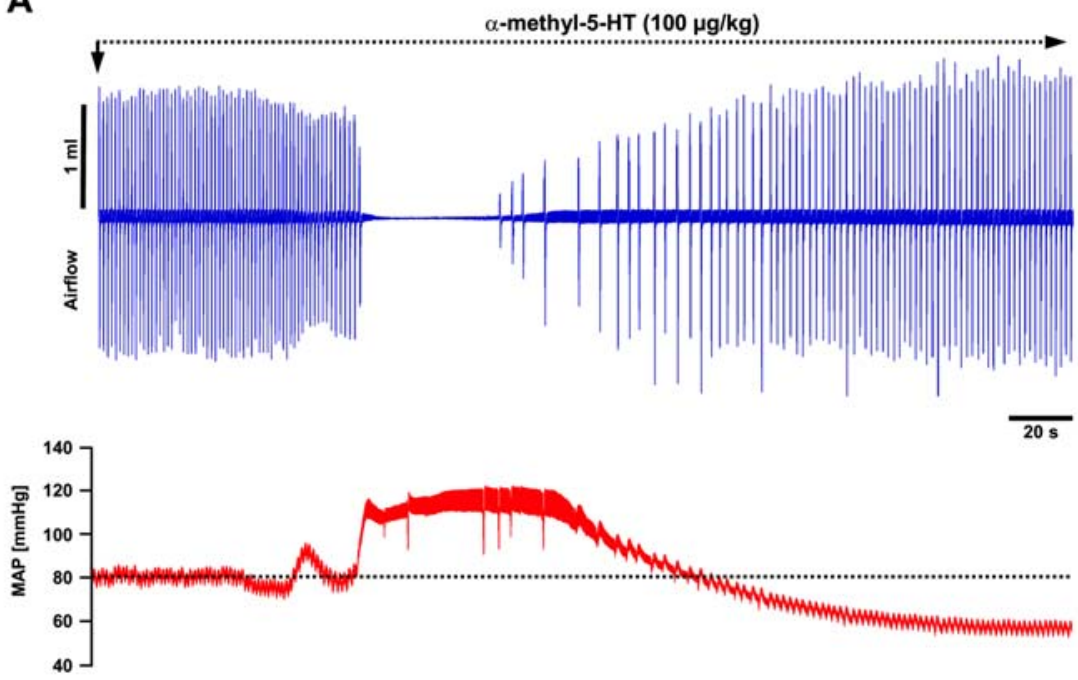

B
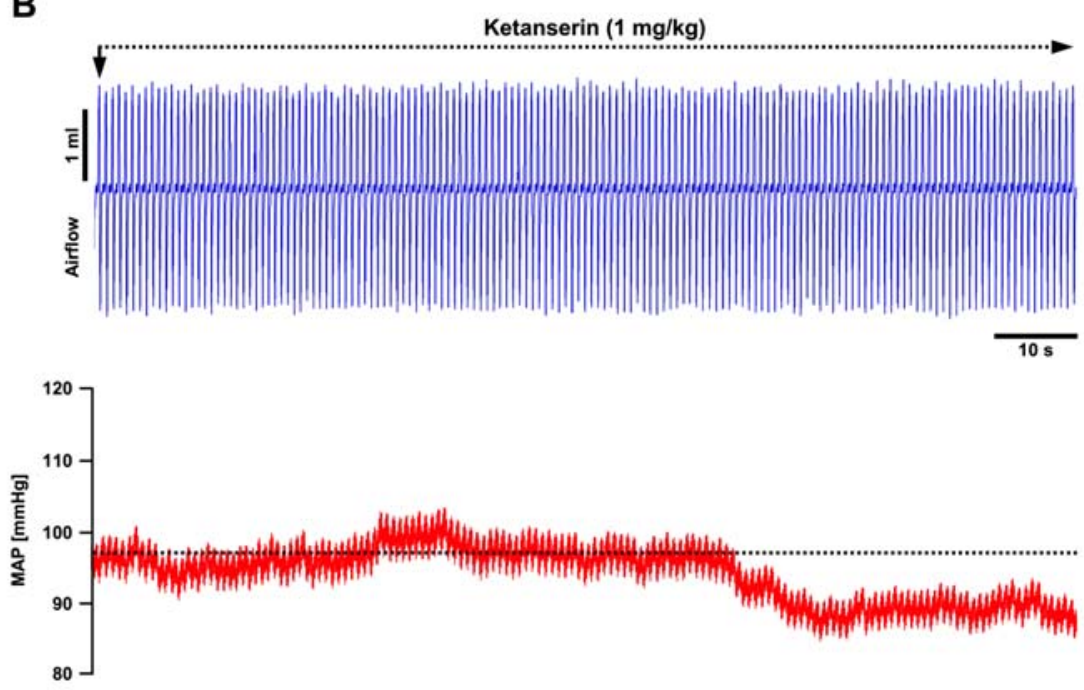

Figure 62. In-vivo analysis of systemic effects of the 5-HT $2 \mathrm{~A}$ receptor isoform on breathing pattern and mean arterial pressure:

(A) systemic application of the $5-\mathrm{HT}_{2 \mathrm{~A}} \mathrm{R}$-agonist $\alpha$-methyl-5- $\mathrm{HT}$ caused a transient respiratory depression which was accompanied by a decrease of the mean arterial pressure (MAP). The MAP was permanently decreased resulting in a hypotonia lasting for about 20 - 30 min.

(B) injection of the $5-\mathrm{HT}_{2 \mathrm{~A}} \mathrm{R}$-antagonist Ketanserin caused a decrease in the MAP, while the respiratory activity was not significantly affected. 


\subsection{Analysis of the distribution patterns of the serotonin 1A, 2A, 2B, 4(a), and 7 receptor isoforms in the ponto-medullary respiratory system}

Systemic application of the agonists for the $5-\mathrm{HT}_{4(\mathrm{a})}$ (see 3.2.4.) and $5-\mathrm{HT}_{1 \mathrm{~A}}$ (see 3.4.4.) receptor isoforms stimulated the respiratory activity and recovered the opioidinduced depression of the respiratory activity without loss of analgesia. In contrast, activation of the $5-\mathrm{HT}_{2 \mathrm{~A}}, 5-\mathrm{HT}_{2 \mathrm{~B}}$, and $5-\mathrm{HT}_{7}$ receptor isoforms did not reveal any significant longer-lasting systemic effects on breathing and failed to compensate the pharmacologically evoked depression of the respiratory activity.

Since selective manipulation of specific 5-HT receptor isoforms led to such heterogeneous results, the spatially distinct distribution of these receptors within the pontomedullary respiratory network was analysed using specific polyclonal antibodies. The immunohistochemistry was performed on $40-\mu \mathrm{m}$-thick transversal slices ranging from the cervical spinal cord to the midbrain level colliculi superiores. The distribution of the labelled cells was plotted using a neurolucida system.

The analysis revealed that all serotonin receptor (5-HTR) isoforms were expressed in the respiratory column, represented as a narrow column in the ventrolateral medulla extending from the facial nucleus to the spinal cord [Alheid et al. (2002)], which includes the medullary ventral respiratory group (VRG), the preBötzinger complex (PBC), the Bötzinger complex (BötC), and the retrofacial nucleus (RFN). The expression patterns of the receptors were also analysed for the pontine A5 cell group and the Kölliker-Fuse nucleus (KF).

The analysis of the distribution patterns (fig. 63) demonstrated a strong immunoreactivity for the $5-\mathrm{HT}_{1 \mathrm{~A}}, 5-\mathrm{HT}_{2 \mathrm{~A}}$, and $5-\mathrm{HT}_{7}$ receptor isoforms in neurones within the VRG, PBC, BötC, RFN, and the KF, whereas the $5-\mathrm{HT}_{2 \mathrm{~B}}$ and $5-\mathrm{HT}_{4(\mathrm{a})}$ receptor isoforms indicated a less dense immunoreactivity in these regions.

The 5- $\mathrm{HT}_{1 \mathrm{~A}}, 5-\mathrm{HT}_{2 \mathrm{~A}}, 5-\mathrm{HT}_{2 \mathrm{~B}}$, and $5-\mathrm{HT}_{7}$ receptor-positive cells mainly appeared as small fusiform cells with a cell diameter of about $10-20 \mu \mathrm{m}$. In contrast, the cell diameter of the $5-\mathrm{HT}_{4(\mathrm{a})} \mathrm{R}$-immunoreactive cells ranged from $20-30 \mu \mathrm{m}$. Moreover, the cells expressing the $5-\mathrm{HT}_{4(\mathrm{a})} \mathrm{R}$ showed a distinct labelling of cell processes (fig. 65). The morphology of the $5-\mathrm{HT}_{4(\mathrm{a})} \mathrm{R}$-positive cells regarding to cell size and process labelling suggests that the $5-\mathrm{HT}_{4(\mathrm{a}) \mathrm{R}} \mathrm{R}$ is possibly expressed in neurones of a different subset of cells within the respiratory system, especially within the PBC, compared to cells expressing the $5-\mathrm{HT}_{1 \mathrm{~A}}, 5-\mathrm{HT}_{2 \mathrm{~A}}, 5-\mathrm{HT}_{2 \mathrm{~B}}$, or $5-\mathrm{HT}_{7}$ receptor. 


\section{$5-\mathrm{HT}_{1 \mathrm{~A}} \mathrm{R} \quad 5-\mathrm{HT}_{4(\mathrm{a})} \mathrm{R} \quad 5-\mathrm{HT}_{7} \mathrm{R} \quad 5-\mathrm{HT}_{2 \mathrm{~A}} \mathrm{R} \quad 5-\mathrm{HT}_{2 \mathrm{~B}} \mathrm{R}$ \\ RVLM/PBC}
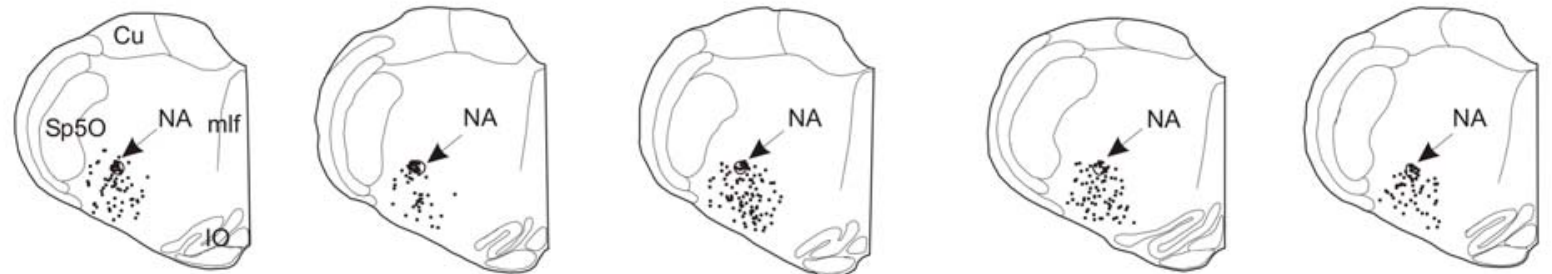

RVLM/BötC
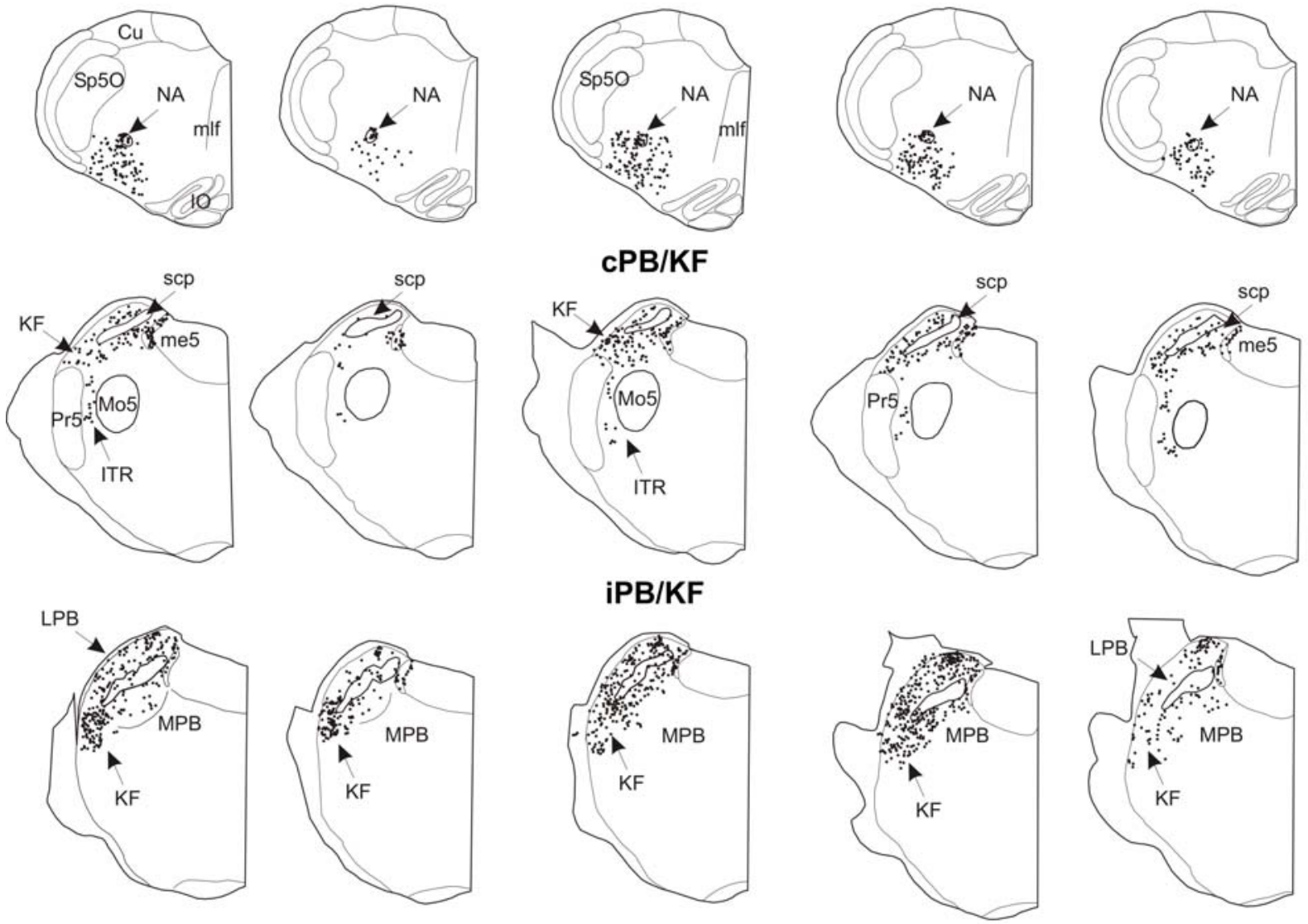

rPB/KF
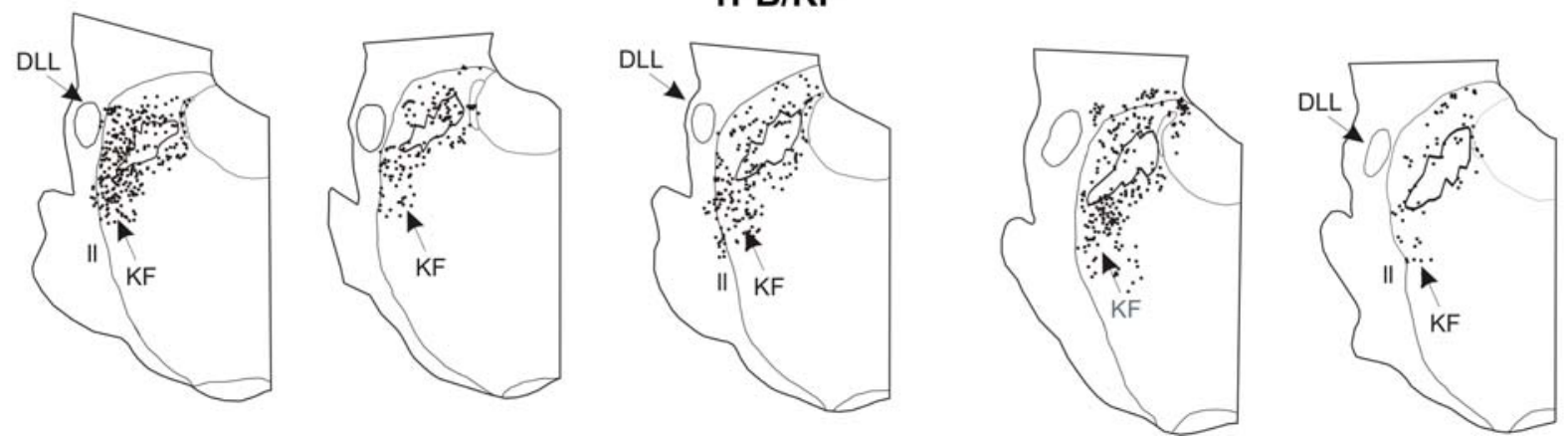

Figure 63. Expression patterns of the serotonin 1A, 4(a), 7, 2A, and 2B receptor isoforms within the ponto-medullary respiratory network: abbreviations: nucleus ambiguus (NA), preBötzinger complex (PBC), Bötzinger complex (BötC), Kölliker-Fuse nucleus (KF), oral part of the spinal trigeminal nucleus (Sp5O), inferior olive (IO), medial longitudinal fasciculus (mlf), motor trigeminal nucleus (Mo5), mesencephalic trigeminal tract (me5), principal sensory trigeminal nucleus (Pr5), superior cerebellar peduncle (scp), dorsal nucleus of the lateral lemniscus (DLL), medial parabrachial nucleus (MPB), lateral parabrachial nucleus (LPB), intermediate interstitial nucleus of the medial longitudinal fasciculus (II), cuneate nucleus (Cu), caudal, intermediate, or rostral parabrachial/Kölliker-Fuse complex (cPB/KF, iPB/KF, or $\mathrm{PPB} / \mathrm{KF}$ ), inter-trigeminal region (ITR), rostral ventro-lateral medulla (RVLM). 


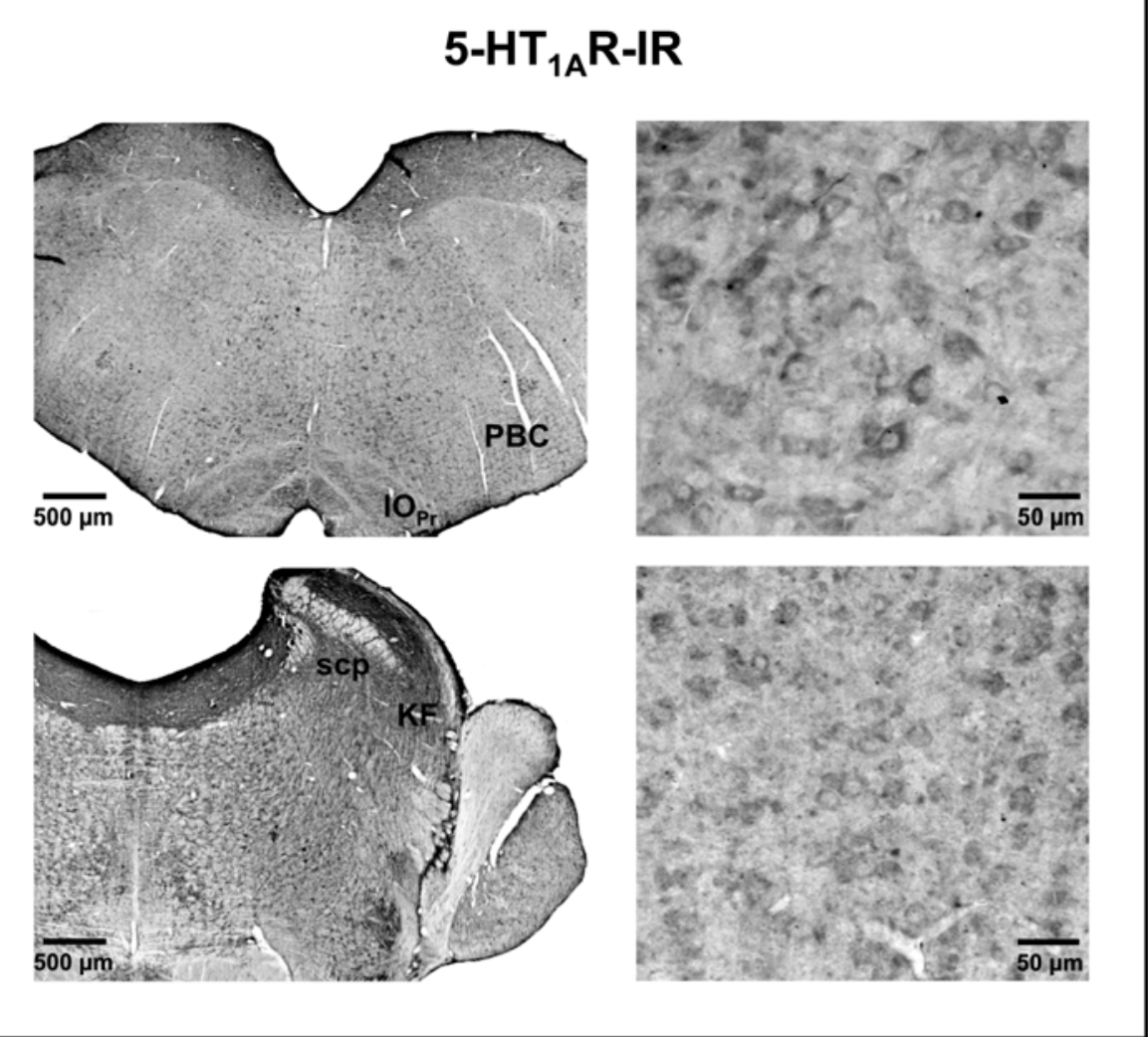

Figure 64. Expression of the $5-\mathrm{HT}_{1 \mathrm{~A}}$ receptor in the preBötzinger complex and the Kölliker-Fuse nucleus

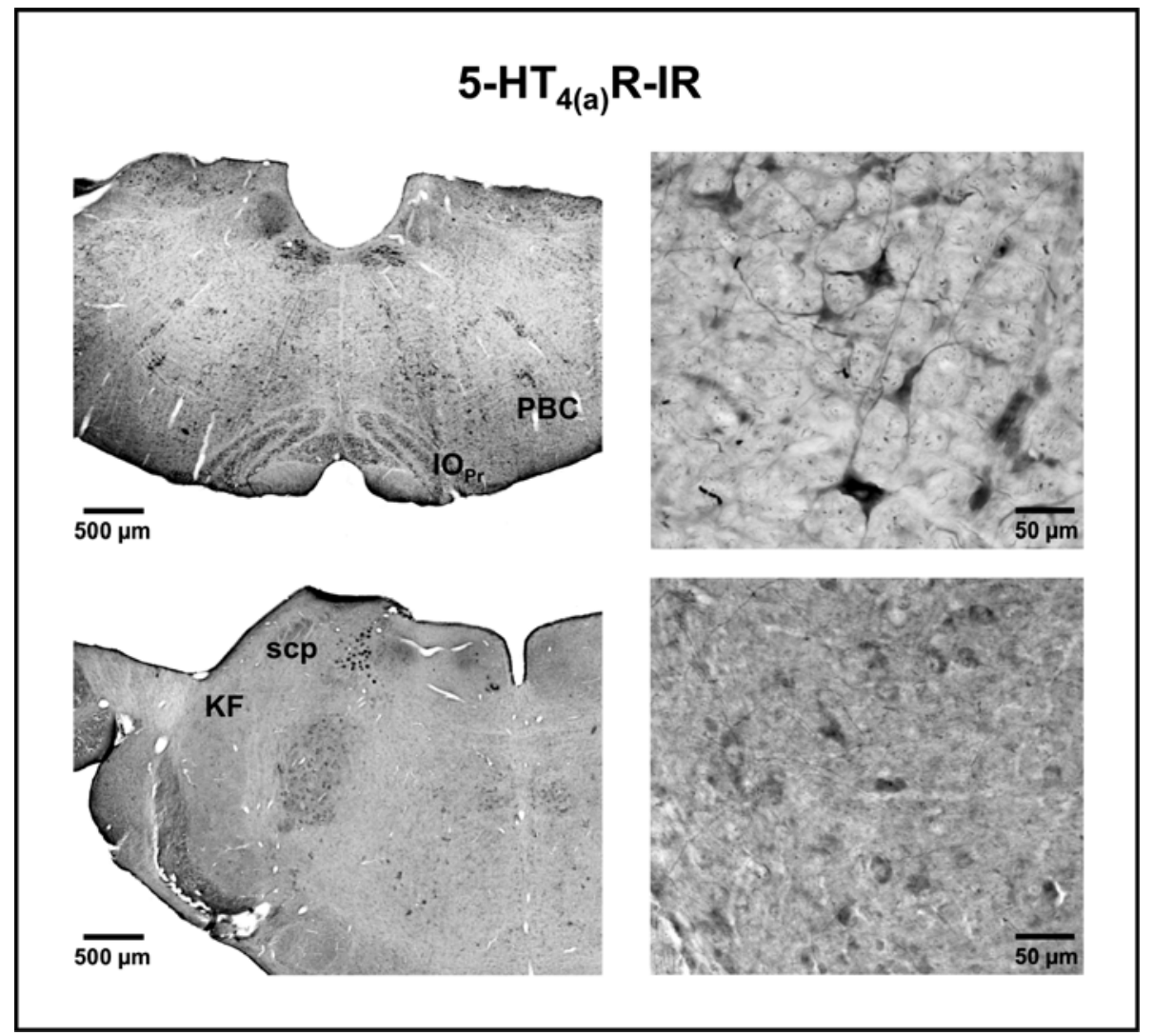

Figure 65. Expression of the $5-\mathrm{HT}_{4(\mathrm{a})}$ receptor in the preBötzinger complex and the Kölliker-Fuse nucleus 


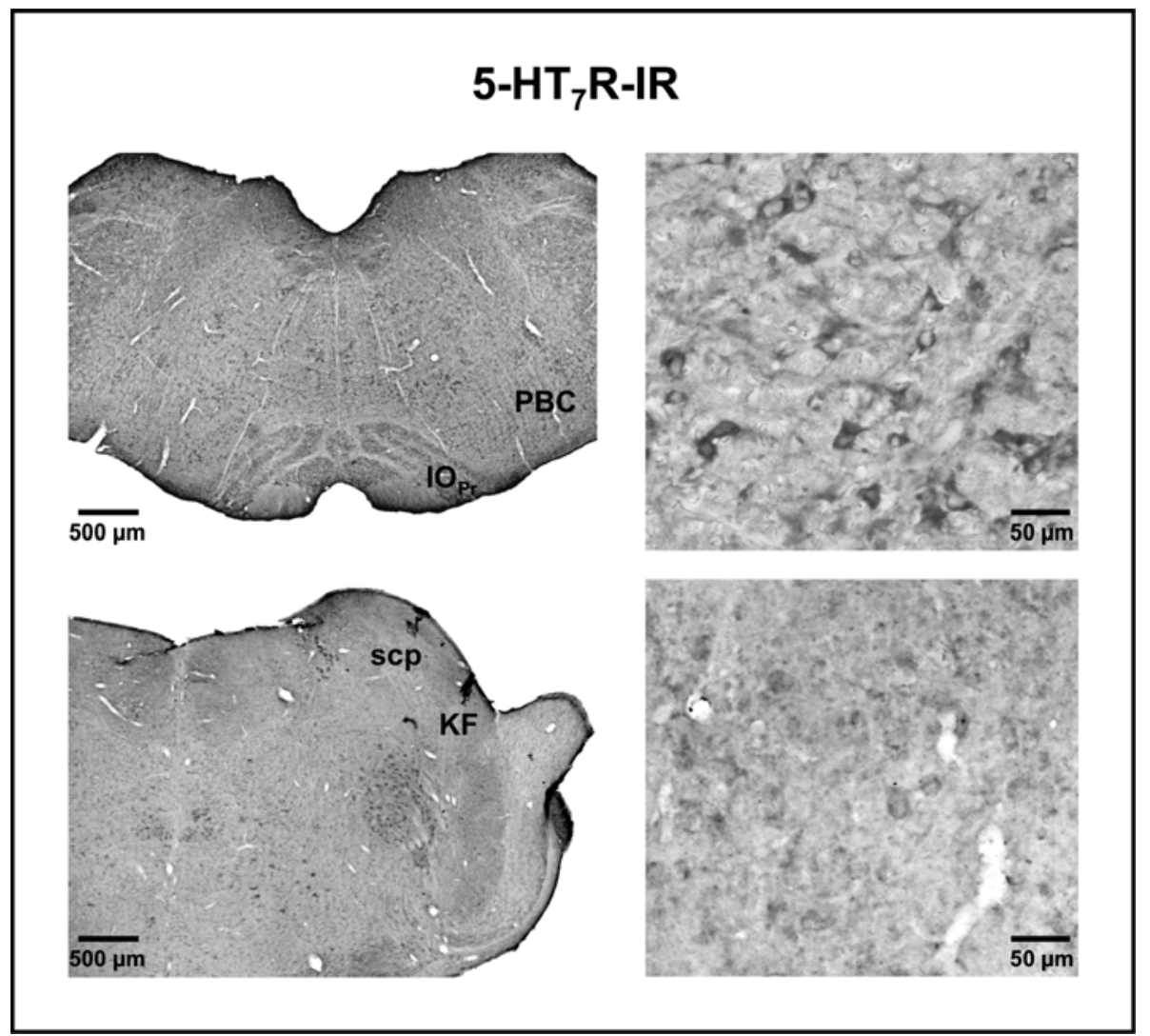

Figure 66. Expression of the $5-\mathrm{HT}_{7}$ receptor in the preBötzinger complex and the Kölliker-Fuse nucleus

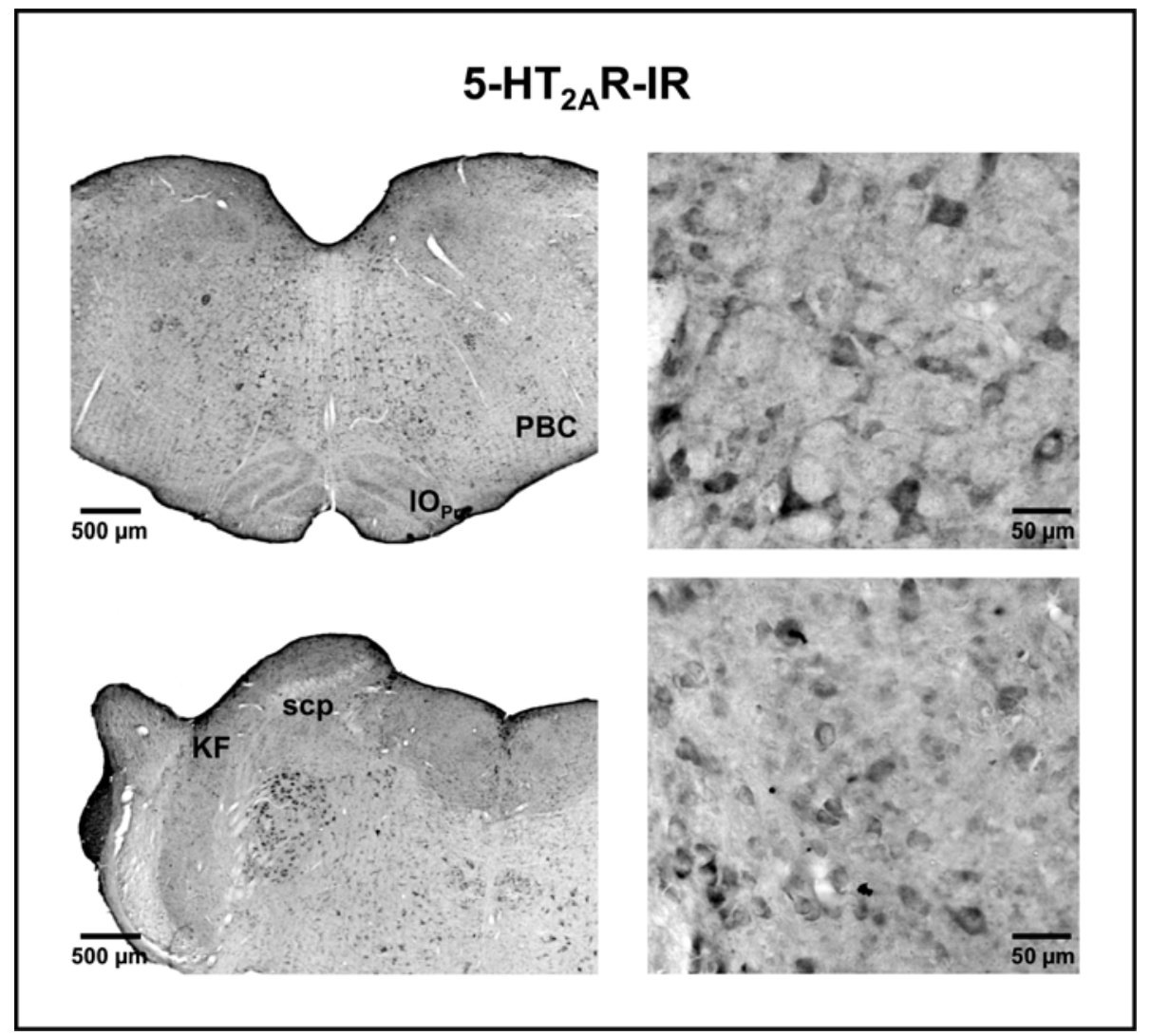

Figure 67. Expression of the $5-\mathrm{HT}_{2 \mathrm{~A}}$ receptor in the preBötzinger complex and the Kölliker-Fuse nucleus 
- Results -

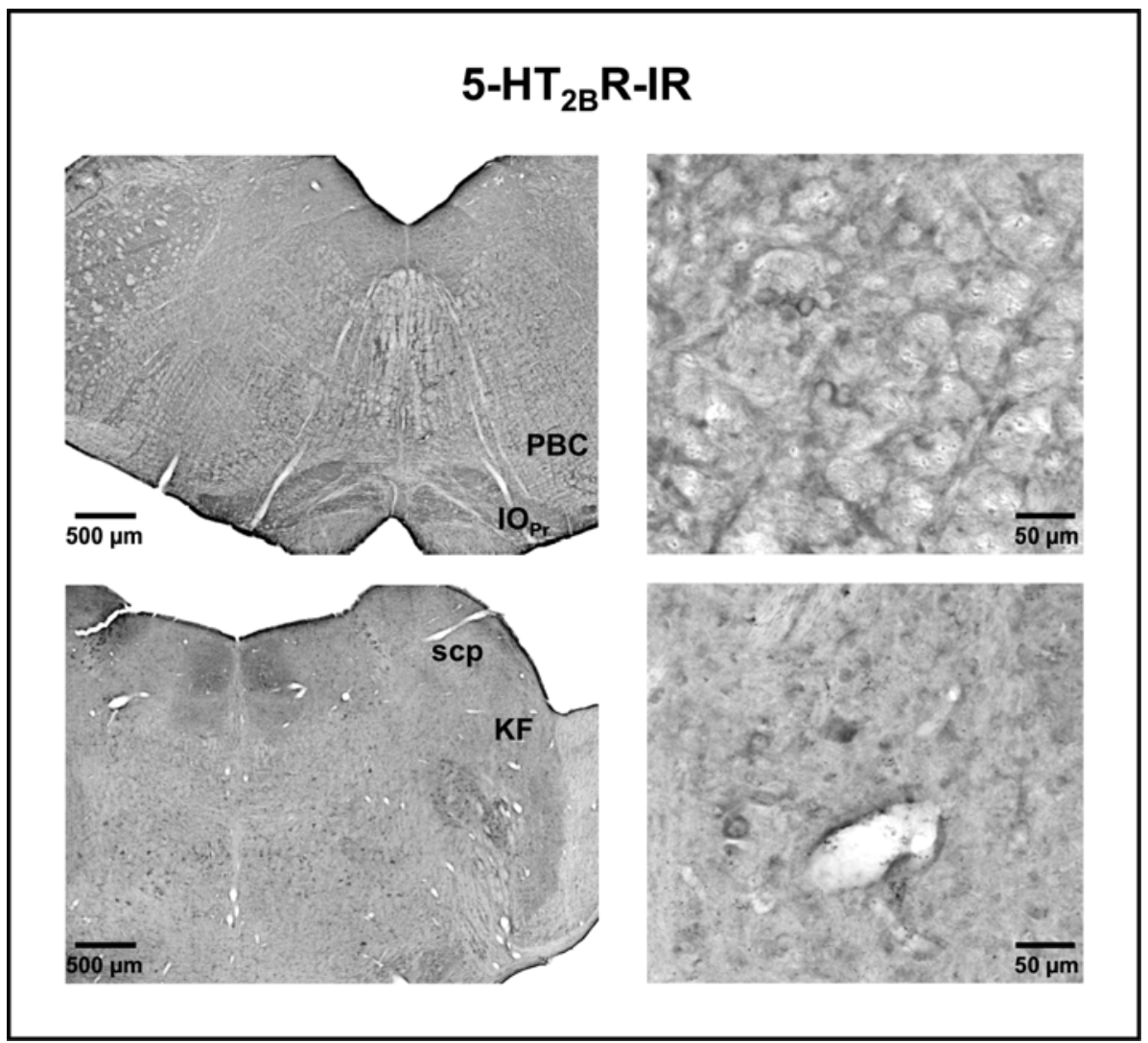

Figure 68. Expression of the $5-\mathrm{HT}_{2 \mathrm{~B}}$ receptor in the preBötzinger complex and the Kölliker-Fuse nucleus 


\section{Discussion}

\subsection{The opioid-induced depression of the respiratory activity compensated by selective activation of the serotonin 4(a) receptor isoform without loss of the analgetic effects of the opioid}

The male mutants of the recently generated knock-out mouse for the $5-\mathrm{HT}_{4}$ receptor exhibit an attenuation of stress-induced hypophagia [Compan et al. (2004)], but it is still unclear whether these $5-\mathrm{HT}_{4} \mathrm{R}$-null mice have disturbances of breathing. The expression and functional role of the $5-\mathrm{HT}_{4(\mathrm{a})} \mathrm{R}$ in the respiratory system has not been investigated precisely so far. Recent cloning of the $5-\mathrm{HT}_{4}$ receptor [Claeysen et al. (1996)] initiated the development of $5-\mathrm{HT}_{4} \mathrm{R}$-isoform-specific immunocytochemistry and pharmacology. The production of polyclonal monospecific antibodies against a synthetic peptide that corresponds to the C-terminal sequence of the $5-\mathrm{HT}_{4(\mathrm{a})} \mathrm{R}$ isoform (amino acids $\mathrm{His}^{364}$ to $\mathrm{Pro}^{380}$ ) (see 3.1.1.4.1.) allowed for specific identification of the spatial expression of $5-\mathrm{HT}_{4}$ receptors in the central nervous system, including the brainstem [Manzke et al. (2002)]. The immunohistochemistry (see 3.2.1.) and the single-cell RT-PCR analysis (see 3.2.2.) demonstrated that the 5- $\mathrm{HT}_{4(\mathrm{a})}$ and $\mu$-opioid receptors are co-expressed in inspiratory neurones. These findings suggest that the $5-\mathrm{HT}_{4(\mathrm{a})}$ and $\mu$-opioid receptor-mediated signalling pathways are co-existent in inspiratory neurones and therefore are capable of interacting in an antagonistic manner (fig. 69). The possible convergent signal transduction pathway of the 5- $\mathrm{HT}_{4(\mathrm{a})}$ and $\mu-$ opioid receptors based on the facts that $\mu$-opioid receptors operate through $\mathrm{G}_{\mathrm{i} / \mathrm{o}}$-proteins to inhibit the adenylyl cyclase (AC) resulting in a decrease of the intracellular cyclic adenosine $5^{\prime}, 3^{\prime}$-monophosphate concentration ([cAMP] $]_{i}$ [Ballanyi et al. (1997)], while 5- $\mathrm{HT}_{4(\mathrm{a})}$ receptors counteract by activating $\mathrm{G}_{\mathrm{s}}$-proteins to increase the [cAMP]i [Heine et al. (2002)].

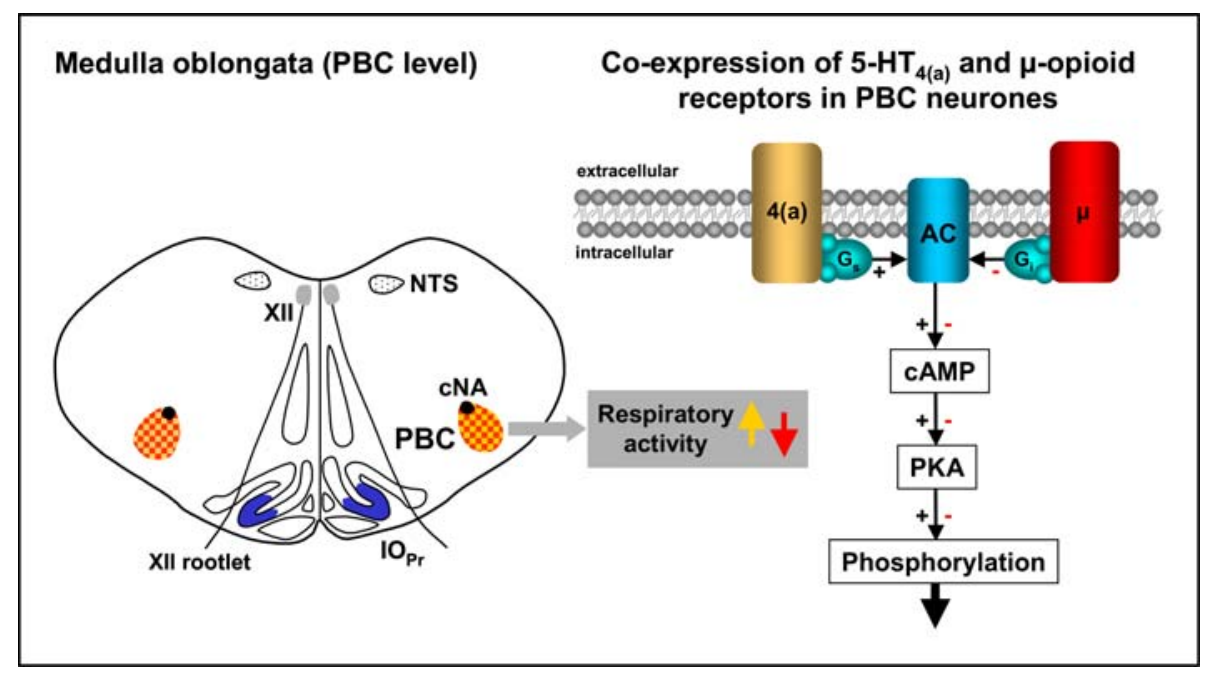

Figure 69. Convergent signal transduction pathways of the $5-\mathrm{HT}_{4(\mathrm{a})}$ and $\mu$-opioid receptors in neurones of the preBötzinger complex: abbreviations: nucleus solitary tract (NTS), nucleus ambiguus, compact part (cNA), nucleus hypoglossus (XII), principal part of the inferior olive $\left(I_{\mathrm{Pr}}\right)$, adenylyl cyclase (AC), cyclic adenosine $5^{\prime}, 3^{\prime}$-monophosphate (CAMP), protein kinase A (PKA), serotonin 4(a) receptor $[4(\mathrm{a})]$, $\mu$-opioid receptor $(\mu)$, stimulating or inhibitory hetero-trimeric guanine-nucleotide-binding protein $\left(G_{s}\right.$ or $\left.G_{i}\right)$.

The physiological significance of such potential interaction between $5-\mathrm{HT}_{4(\mathrm{a})}$ and $\mu$ opioid receptor-mediated signalling in the regulation of respiration was further explored in the perfused rat brainstem-spinal cord preparation [Manzke et al. (2003)] 
which contains the fully intact respiratory network. This experimental model retains an in-vivo-like respiratory behaviour of non-anaesthetised mature mammals. It allows for analysis of respiratory activity and regulation including nociceptive reflexes [Paton et al. (1994), Paton (1996a), Paton (1996b)]. The findings from the perfused brainstem preparation have been finally verified in a fully intact animal preparation (see 3.2.3.). The effects of the agonist BIMU-8 specific for the $5-\mathrm{HT}_{4(\mathrm{a})}$ receptor [Claeysen et al. (2003), Ponimaskin et al. (2001),] on ongoing respiratory activity were tested. The vascular application of BIMU-8 significantly increased the phrenic nerve activity in a dose dependent manner [Manzke et al. (2003)]. The experiments in the fully intact animal confirmed that application of BIMU-8 significantly increased the respiratory minute volume (RMV) in-vivo (see 3.2.3.). The antagonist GR 113808, which is specific for the $5-\mathrm{HT}_{4}$ receptor [Claeysen et al. (2003)], blocked this stimulating effect of BIMU-8 in the perfused rat brainstem-spinal cord preparation as well as in the fully intact animal. This demonstrates that the stimulatory effects are indeed due to $5-\mathrm{HT}_{4}$ receptor activation. Involvement of a $5-\mathrm{HT}_{4} / \mathrm{G}_{\mathrm{s}}$-signalling in the regulation of respiratory activity was confirmed by the findings that application of dibutyryl-cAMP, a cAMP analogue, accelerated the phrenic nerve activity, whereas the application of the adenylyl cyclase inhibitor SQ 22,536 [Haslam et al. (1978)] decreased phrenic nerve activity [Manzke et al. (2003)]. Since 5- $\mathrm{HT}_{3}$ receptors, which are transmitter-gated $\mathrm{Na}^{+} / \mathrm{K}^{+}$-channels, are not functionally expressed in respiratory neurones [Morin et al. (1990), Richter et al. (2000)], a co-activation of this receptor-isoform by BIMU-8 [Claeysen et al. (2003)] could be excluded.

Fentanyl, a synthetic opioid related to phenylpiperidines and specific for the $\mu$-opioid receptor, is widely used for anaesthesia and for the relief of acute and chronic pain, although it produces serious adverse reactions, such as hypoventilation [Ballanyi et al. (1997), Dunn and Wolfe (2000), Takeda et al. (2001)]. Furthermore, fentanyl is estimated to be 80 times as potent as morphine [Goodman and Gilman (1990)]. Due to its clinical relevance and pharmacological potency, fentanyl was selected to test the physiological consequences of $\mu$-opioid receptor activation. Application of fentanyl to the perfused rat brainstem-spinal cord preparation induced an almost complete suppression of the respiratory activity or apnoea that would have been lethal under normal conditions [Manzke et al. (2003)]. Similarly in the brainstem preparation spontaneous respiratory movements were completely blocked in the fully intact animal model. Therefore, it was tested whether the activation of the $5-\mathrm{HT}_{4}$ receptor-mediated signalling pathway is effective in overcoming the fentanyl-induced depression of respiratory activity [Ballanyi et al. (1997), Denavit-Saubie et al. (1978)]. To verify the capacity of $5-\mathrm{HT}_{4}$ receptors to recover respiratory activity, successive applications of fentanyl and of BIMU-8 were performed. The crucial result was that consecutive applications of BIMU-8 indeed re-established a stable respiratory activity in the perfused brainstem preparation [Manzke et al. (2003)]. This effect was fully reproduced in-vivo (see 3.2.3.). In the latter cases, subsequent application of BIMU-8 recovered the fentanyl-induced apnoea and restored a stable breathing.

Finally, we investigated whether or not the selective activation of the $5-\mathrm{HT}_{4}$ receptor also obliterates the nociceptive function of opioids. The C-fibre reflexes (CFRs) were tested in the brainstem-spinal cord preparation and the tail-flick response (TFR) invivo [Manzke et al. (2003)]. In the perfused brainstem preparation fentanyl induced the expected anti-nociceptive effects, as seen by the significant reduction of the CFRs. The effects obtained in in-vivo animals were even more pronounced. Here, fentanyl produced strong anti-nociceptive effects that resulted in a complete abolishment of the TFR (see 3.2.3.). The most important finding was that subsequent 
application of BIMU-8 was sufficient to re-establish a stable respiration in both test systems without any significant effects on the CFRs or the TFR. An additional application of the opioid receptor antagonist naloxone immediately re-established the TFR. The explanation of this surprising continuity of analgesia caused by fentanyl is that $5-\mathrm{HT}_{4(\mathrm{a})}$ receptors are not expressed in spinal interneurones of the dorsal horn (see 3.2.4.), while they express abundantly the $\mu$-opioid receptor. Consequently, the decrease of the $[\mathrm{cAMP}]_{\mathrm{i}}$ due to $\mu$-opioid receptor activation is not counteracted by selective activation of the $5-\mathrm{HT}_{4(\mathrm{a})}$ receptor (fig. 70).

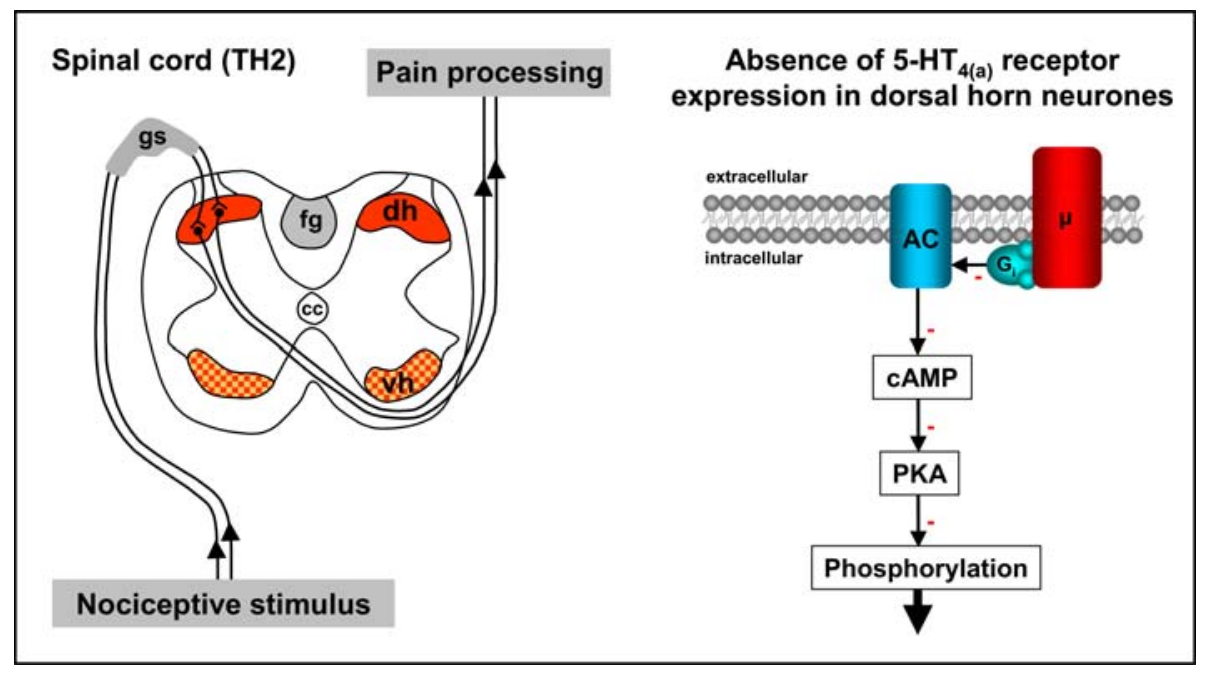

Figure 70. Absence of the $\mathbf{5}-\mathrm{HT}_{4(\mathrm{a})}$ receptors in neurones of the dorsal horn: abbreviations: ventral horn (vh), dorsal horn (dh), canalis centralis (cc), fasciculus gracilis (fg), ganglion spinale (gs), adenylyl cyclase (AC), cyclic adenosine $5^{\prime}, 3^{\prime}$-monophosphate (cAMP), protein kinase A (PKA), $\mu$ opioid receptor $(\mu)$, inhibitory hetero-trimeric guanine-nucleotide-binding protein $\left(G_{i}\right)$.

The opioid-induced respiratory depression is generally known from many clinical situations as well as from experimental studies [Ballanyi et al. (1997), Puig and Montes (1998), Yeadon and Kitchen (1989), Yeadon and Kitchen (1990)]. The opioid receptors are seven-transmembrane domain receptors from 3 gene families $(\mu, \kappa$, and $\delta$ opioid receptors) which have been identified, characterised and cloned [Akil et al. (1996), Knapp et al. (1995)]. The receptors are activated by both endogenous and exogenous ligands. The $\mu$ and $\delta$ receptors are activated by endogenous $\beta$-endorphins and enkephalins, whereas the $\kappa$ receptor is activated by dynorphins. Application of exogenous opioids, drugs like morphine or fentanyl, is associated with depression of central respiratory activity in mammals. There is evidence that opioidinduced respiratory depression is caused by direct actions on the brainstem [Flórez and Hurlé (1993)]. Furthermore, in-vivo studies have suggested that $\mu$ - and $\delta$-opioid receptors participate in opioid-induced respiratory depression, while $\kappa$-opioid receptors are not involved [Flórez and Hurlé (1993), Freye et al. (1991), Freye et al. (1992), Shook et al. (1990)], although $\kappa$ - and $\mu$-opioid receptors might have a similar distribution pattern in the brainstem [Mansour et al. (1988)]. The opioid receptor antagonist naloxone reverses respiratory depression caused by foetal asphyxia [Chernick and Craig (1982)]. Moreover, recent investigations in mice lacking the $\mu$ opioid receptor [Matthes et al. (1996), Romberg et al. (2003), Sora et al. (1997)] indicated that the anti-nociceptive effects and respiratory depression caused by morphine-6-glucuronide, a metabolite of morphine with potent analgesic properties, and morphine are linked to the same gene product that is the $\mu$-opioid receptor [Romberg et al. (2003)]. Based on radioligand binding studies, the $\mu$-opioid receptor was subdivided into $\mu-1$ and $\mu-2$ receptors [Pasternak et al. (1980), Wolozin and Pasternak 
(1981)]. In-vivo studies revealed that naloxazone selectively blocks morphine-induced anti-nociception, but it does not block morphine-induced respiratory depression [Ling et al. (1985), Ling et al. (1986)]. These results suggest that respiratory depression is mainly mediated by the $\mu-2$ receptor. However, the exact pharmacological actions of opioids on respiratory activity by activation of $\mu-, \delta$-, and $\kappa$-opioid receptors in the respiratory system remain to be elucidated. At presence, we can state that respiratory depression is predominantly caused by $\mu$-opioid receptor activation.

The $\mu$-opioid receptors ( $\mu$-OR) are known to modify spinal reflexes [Clarke et al. (2001), Herz and Millan (1990)] through both inhibition of spinal pathways at the spinal cord level and supraspinal augmentation of descending inhibitory bulbospinal pathways. The latter originate within the periaqueductal gray matter (PAG) and descend to the spinal cord [Clarke et al. (1998)]. This action of $\mu$-OR depends on a tonic release of noradrenaline, acting on $\alpha_{2}$-adrenergic receptors in neurones of the spinal cord. According to Clarke et al. (1998), spinal inhibition is most likely the predominant mechanism of opioid action when given in clinical concentrations. Since $5-\mathrm{HT}_{4(\mathrm{a})}$ receptors are not expressed in neurones of the dorsal horn, the action of $\mu-$ opioid receptors on spinal cord level is not affected (fig. 70).

Taken together, this study provides evidence that selective activation of $5-\mathrm{HT}_{4}$ receptors in neurones of the medullary respiratory centre represents a new way for the treatment of respiratory depression induced by opioids. Stimulation of $5-\mathrm{HT}_{4}$ receptors effectively counteracts fentanyl-induced respiratory depression without compromising its anti-nociceptive potency. An inspiring possibility is that application of $5-\mathrm{HT}_{4}$ receptor agonists could be used for the treatment of critical respiratory events caused by fentanyl in post-operative situations and for the treatment of pain patients against overdose of opioids [Dunn and Wolfe (2000)]. However, 5-HT 4 receptor expression has also been described in the cortex, the hippocampus, the nigrostriatal and mesolimbic systems, the gastrointestinal tract, and the heart [Bach et al. (2001), Bickmeyer et al. (2002), Eglen et al. (1995), Manzke et al. (2002), Waeber et al. (1993)]. Such wide distribution might possibly restrict systemic application. Outside the brain, messenger RNA expression specific for the $5-\mathrm{HT}_{4(\mathrm{a})}$ and $5-\mathrm{HT}_{4(\mathrm{~b})}$ receptor isoform has been described in the atrium of the heart [Bach et al. (2001)]. The treatment with $5-\mathrm{HT}_{4}$ receptor agonists might therefore cause sideeffects as described for cisapride (Propulside ${ }^{T M}$ ), a pro-kinetic agent which was used to treat patients suffering from gastroparesis, ileus, and gastrooesophageal reflux, which led in some cases to heart arrhythmia [Kaumann et al. (1996), Kii and Ito (1997)].

Nevertheless, a straight-forward therapy that is targeted on convergent intracellular signal transduction pathways by means of a receptor isoform-specific pharmacology [Richter et al. (1997)] might open novel strategies for an effective treatment in a wide spectrum of critical clinical situations. 


\subsection{Development of the serotonin 4(a) and $\mu$-opioid receptor expression in the preBötzinger complex (PBC)}

The purpose of the development study was to address the question of whether the anatomical conditions of the previously described molecular model exists during development. Furthermore, the degree of differentiation of the PBC was investigated to obtain informations about a neurotrophic function of the $5-\mathrm{HT}_{4(\mathrm{a})}$ and $\mu$-opioid receptors for the formation and/or stabilisation of the respiratory network.

In the present study the expression of the $5-\mathrm{HT}_{4(\mathrm{a})} \mathrm{R}$ was analysed on protein level using a polyclonal monospecific anti-5- $\mathrm{HT}_{4(\mathrm{a})} \mathrm{R}$ antibody (see 3.1.1.4.1.). Earlier development studies analysed the expression of the $5-\mathrm{HT}_{4} \mathrm{R}$ on RNA level using in-situhybridisation [Ullmer et al. (1996), Vilaro et al. (1996)]. However, these studies described that the $5-\mathrm{HT}_{4} \mathrm{R}$ is not expressed in the rat brainstem. To clarify this contradiction, the ventral respiratory group (VRG) containing the PBC and the ambigual nucleus (NA) was dissected from the slice preparation in a rostral-caudal extension of $500 \mu \mathrm{m}$ and analysed for $5-\mathrm{HT}_{4(\mathrm{a})} \mathrm{R}$ expression using RT-PCR (see 3.3.1.). During all development stages, an amplification product specific for the $5-\mathrm{HT}_{4(\mathrm{a})} \mathrm{R}$ was detectable. Furthermore, autoradiographic studies using the antagonist GR 113808, specific for the $5-\mathrm{HT}_{4} \mathrm{R}$ [Claeysen et al. (2003)], demonstrated the expression of the $5-\mathrm{HT}_{4} \mathrm{R}$ in embryonic motoregions within the brainstem [Jakeman et al. (1994), Waeber et al. (1994)] which was in accordance with the antibody-dependent 5$\mathrm{HT}_{4(\mathrm{a}) \mathrm{R}} \mathrm{R}$-immunoreactivity. These data additionally confirmed the $5-\mathrm{HT}_{4} \mathrm{R}$ expression in neurones within the embryonic brainstem.

The earliest development stage analysed ( $E$ 14) indicated the expression of the 5$\mathrm{HT}_{4(\mathrm{a})} \mathrm{R}$ in neurones of the spinal cord in which the receptor expression was restricted to the ventral horn. Dorsal horn neurones did not show any specific $5-\mathrm{HT}_{4(\mathrm{a})} \mathrm{R}$-immunoreactivity which maintained unchanged during later periods of development. The nucleus ambiguus (NA) and the appearance of the principal nucleus of the inferior olive (IOPr) [Alheid et al. (2002), Schwarzacher et al. (1995)] are necessary for the anatomical identification of the PBC. At the development stage $E 16$, all neurones within the ambigual nucleus, which is not formed until E 15/16 [Altman and Bayer (1995)], expressing the $5-\mathrm{HT}_{4(\mathrm{a})} \mathrm{R}$ were also $\mu$-OR-immunoreactive. The strong coexpression of both receptors was also visible in neurones within the region ventral of the NA at later periods of development and maintained unchanged. The substance P-reactive neurokinin-1 receptor has been proposed as a marker for the embryonic and neo-/postnatal PBC [Gray et al. (1999), Gray et al. (2001), Pagliardini et al. (2003)] and was therefore additionally used to ensure that the $5-\mathrm{HT}_{4(\mathrm{a})} \mathrm{R}$-positive neurones were indeed localised within the PBC. The first clear distinct NK-1Rimmunoreactivity (NK-1R-IR) was visible at $E 18$ which is in accordance with the findings of Pagliardini et al. (2003) who observed the first NK-1R-IR at E 17. The results of the development study suggest that opioid-induced depression of the respiratory activity might be compensated through selective activation of the $5-\mathrm{HT}_{4(\mathrm{a})} \mathrm{R}$ from the time when the first spontaneous respiratory activity appears (E 16) [Di Pasquale et al. (1992)]. It is assumed that opioid-induced analgesia continues due to the fact that the $5-\mathrm{HT}_{4(\mathrm{a})} \mathrm{R}$ is not expressed in dorsal horn neurones during development. 
The neuronal respiratory rhythm already initiates at embryonic development stages. Using the fetal rat brainstem-spinal cord in-vitro preparation, Di Pasquale et al. (1992) demonstrated that the fetal 'respiratory-like activity' did not occur until the development stage E 15 and appeared for the first time at the development stage E 16 in $30 \%$ of preparations with fluctuating frequency and amplitude bursts. At this development stage, the $5-\mathrm{HT}_{4(\mathrm{a})} \mathrm{R}$-immunoreactivity was restricted to the ambigual nucleus. At an age of E 18 - E 20, the fetal respiratory-like activity might be similar to the neonate [Greer et al. (1992), Smith et al. (1990)]. At that time, the 5-HT $\mathrm{H}_{\text {(a) }} \mathrm{R}$ immunoreactivity indicated its maximal ventro-lateral extension and seems to mark the anatomical extension of the PBC which was shown by double labellings of 5$\mathrm{HT}_{4(\mathrm{a})}$ and NK-1 receptors (see 3.3.2.). At the level of the PBC, the NK-1R-immunoreactivity showed the highest density and strength of neurone-labelling which corresponded with the expression pattern of the $5-\mathrm{HT}_{4(\mathrm{a})} \mathrm{R}$ (see 3.3.3.). Furthermore, the serotonergic influence on the frequency of the respiratory rhythm is at maximum at this development stage [Hilaire and Duron (1999)]. This provide evidence that the 5$\mathrm{HT}_{4(\mathrm{a})} \mathrm{R}$ is possibly involved in the formation and stabilisation of the respiratory network. According to Di Pasquale et al. (1992) and Onimaru et al. (2002), the respiratory rhythm is stable and comparable with the neonate at the development stage E 20, while the influence of serotonin on the respiratory rhythm frequency [Hilaire and Duron (1999)] and the extension of the $5-\mathrm{HT}_{4(\mathrm{a})} \mathrm{R}$ expression decrease. In later periods of development, $5-\mathrm{HT}_{4(\mathrm{a})} \mathrm{R}$-positive cells were located more ventrally from the $\mathrm{NA}$ (see 3.3.2.). It might be possible that the $5-\mathrm{HT}_{4(\mathrm{a})} \mathrm{R}$-expressing neurones originate from the NA from where they migrate in ventral direction to PBC-regions.

To obtain informations about the degree of differentiation of the PBC, the alteration of the expression pattern of the nestin protein was analysed during the development. Nestin belongs to the VI class of the intermediate filament protein family and is the predominant marker for mammalian stem and progenitor cells. This protein is expressed in the majority of mitotically active CNS and PNS progenitors [Cattaneo and McKay (1990), Lendahl (1997), Lendahl et al. (1990), Mujtaba et al. (1998)]. At the development stage of $E 16$, nestin-positive cells were not visible within the NA and its ventral circumference. In contrast, the development stages E 18 - E 20 indicated a nestin fibre- and cell-staining which was not restricted to the PBC. At this development stage, the PBC was identified on the basis of both the appearance of the principal nucleus of the inferior olive [Alheid et al. (2002), Schwarzacher et al. (1995)] and the NK-1R-immunoreactivity [Gray et al. (1999), Gray et al. (2001), Pagliardini et al. (2003)]. Double labellings of nestin and the glial fibrillary acidic protein (GFAP), which is known as a specific marker for astroglial cells [Privat et al. (1995), Shao and McCarthy (1994)], revealed that the majority of the nestin-positive cells were of the glial type. This result can be interpreted as a massive accumulation of undifferentiated glial cells due to an increase of the brain size and suggest that the PBC is mature prior to birth. This result is in accordance with the findings of Pagliardini et al. (2003) who demonstrated that the majority of the PBC cells are formed between E 12.5 and $E$ 13.5. However, in neonatal development stages ( $P 0$ - $P$ 2), nestinimmunoreactive cells of the NA expressed the 5- $\mathrm{HT}_{4(\mathrm{a})} \mathrm{R}$, whereas these co-immunoreactive cells appeared only sporadically within the ventral periphery of the NA (see 3.3.7.2.). Due to the fact that the $5-\mathrm{HT}_{4(\mathrm{a})} \mathrm{R}$ was not expressed in identified neonatal astroglial cells (see 3.3.8.), in contrast to identified respiratory neurones (see 3.3.6.), it is assumed that the nestin-positive cells expressing the $5-\mathrm{HT}_{4(\mathrm{a})} \mathrm{R}$ are of the neural type which are possibly mitotically active [Cattaneo and McKay (1990), Lendahl (1997)]. However, the function of these cells is still unclear and has to be elucidated. 
The results of the development study suggest that mature neurones are involved in the stabilisation of the respiratory network. Furthermore, mediated by a heterotrimeric $\mathrm{G}_{\alpha 13}$-protein, the $5-\mathrm{HT}_{4(\mathrm{a})} \mathrm{R}$ activates the small GTPases of the RhoA family which have a key position in the control of cell motility and morphology in response to extracellular stimuli. These proteins trigger the formation of contractile stress fibres, resulting in regulation of cell motility [Aspenstrom (1999a), Aspenstrom (1999b), Marshall (1999), Van Aelst and D'Souza-Schorey (1997)]. Activation of the 5-HT $4(\mathrm{a}) \mathrm{R}$ leads to a modification of gene-expression and to a retraction of neurites of neuroblastoma cells [Ponimaskin et al. (2002)]. Moreover, the activity of the protein kinase A can also be increased independently from the [cAMP] $]_{i}$ by an A-kinase-anchoring protein 110 (AKAP 110) ('cAMP-independent' pathway) [Niu et al. (2001)] (fig. 71).

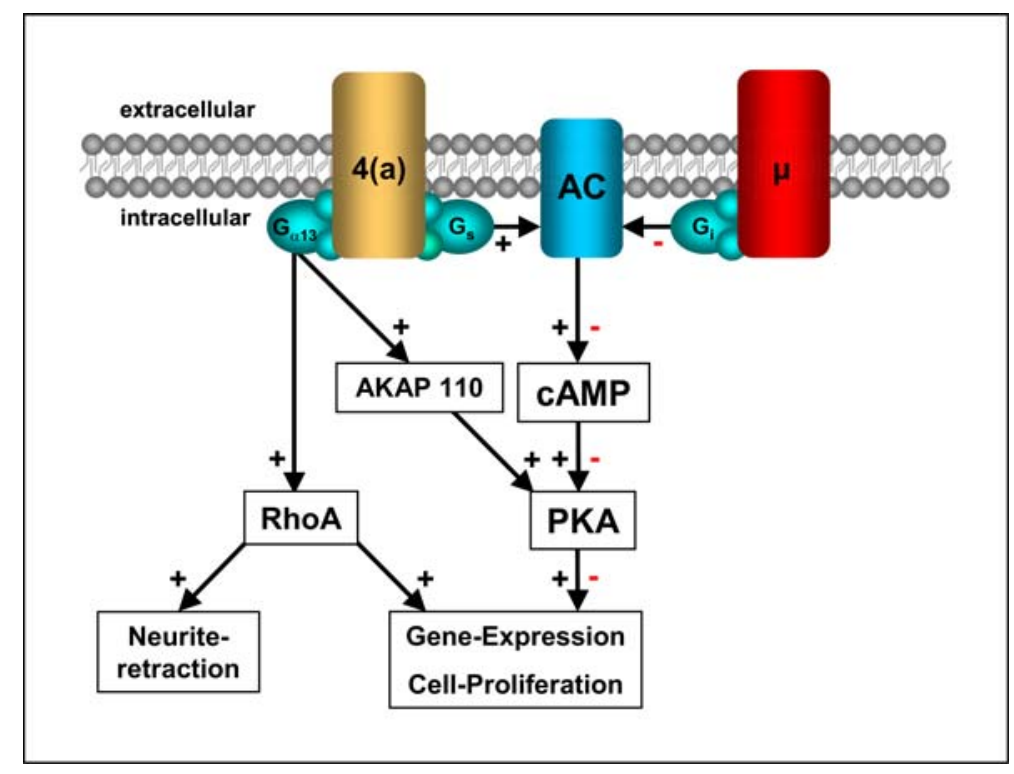

Figure 71. Signal transduction pathways of the $5-\mathrm{HT}_{4(\mathrm{a})}$ and $\mu$-opioid receptors: abbreviations: adenylyl cyclase (AC), protein kinase A (PKA), cyclic adenosine $5^{\prime}, 3^{\prime}$-monophosphate (cAMP), serotonin $4(\mathrm{a})$ receptor $[4(\mathrm{a})], \mu$-opioid receptor $(\mu)$, stimulating or inhibitory hetero-trimeric guanine-nucleotide-binding protein $\left(G_{s}\right.$ or $\left.G_{i}\right)$, hetero-trimeric guanine-nucleotide-binding protein $\alpha 13\left(G_{\alpha 13}\right)$, A-kinaseanchoring protein 110 (AKAP 110).

Serotonin is well known to function as a neurotrophic factor. The specific inhibition of the tryptophan hydroxylase (the rate limiting enzyme in the biosynthesis of serotonin) using p-chlorophenylalanine (PCPA) retarded neuronal maturation [Lauder and Krebs (1978)], reduced the rate of increase in forebrain weight [Hole (1972)], and decreased the density of granule cell dendritic spines [Haring and Yan (1993)]. A transient excess of serotonin during embryonic development stages in knock-out mice lacking the enzyme monoamino-oxidase $A$ resulted in a disrupted bamfield organisation in the primary somatosensory cortex [Cases et al. (1996)]. Furthermore, in-vitro experiments demonstrated that serotonin regulates neuritic growth and synapse formation [Chubakov et al. (1986), Haydon et al. (1987)]. In undifferentiated neuroblastoma cells, high levels of serotonin $(50 \mu \mathrm{M})$ induced a decrease, whereas low levels (50 $\mathrm{nM}$ ) induced an increase in the cytoplasmic tau protein which is a microtubule-associated protein that occurs mainly in neurones and is involved in neurite extension and maintenance [John et al. (1991)]. In adult animals, loss of serotonin results in a loss of protein and molecular markers associated with a mature neuronal phenotype. In adult rats, PCPA, given for 8 days, produced up to a $50 \%$ decrease in the number of non-monoaminergic synapses in the somatosensory cortex [Cheng et al. (1994)]. Serotonin has been implicated with the pathogenesis of 
the sudden infant death syndrome (SIDS) [Kinney et al. (2001), Ozawa and Okado (2002)] and hence probably plays a key role in a variety of cellular processes which are involved in regulating metabolism, proliferation, and morphology of neurones within the brainstem. It might be also possible that these trophic functions of serotonin are partially mediated by the $5-\mathrm{HT}_{4(\mathrm{a})} \mathrm{R}$. On the basis of the hitherto discovered signal transduction pathways of the $5-\mathrm{HT}_{4(\mathrm{a})} \mathrm{R}$, both a PKA-dependent [Lauder (1993), Niu et al. (2001)] and a PKA-independent [Ponimaskin et al. (2002)] modulation of the synapse formation and cell proliferation processes are conceivable.

In contrast to the $5-\mathrm{HT}_{4(\mathrm{a})} \mathrm{R}$, the $\mu$-opioid receptor is negatively coupled to the AC through an inhibitory G-protein. Selective activation of the $\mu$-opioid receptor results in a decrease of the [CAMP] $]_{i}$ and finally to an inhibition of the PKA (fig. 71). Due to the fact that this receptor is strongly co-expressed with the $5-\mathrm{HT}_{4(\mathrm{a})} \mathrm{R}$ in neurones within the preBötzinger complex or its precursor structure, it might be possible that the $\mu$ opioid receptor is also involved in the stabilisation and formation of the respiratory network. Babies have an increased risk to die (SIDS) when the mothers depends on opioids [Chavez et al. (1979), Ostrea et al. (1997), Rajegowda et al. (1978)]. Furthermore, SIDS is partially attributed to a defectively matured respiratory system [Kinney et al. (2001), Kinney et al. (2003)]. According to Lauder (1993), the decreased activity of the PKA can result in an increase of cell proliferation and in an inhibition of neurite outgrowth. Furthermore, cell culture experiments have been demonstrated that activation of $\mu$-opioid receptors inhibited neuronal outgrowth [Miller et al. (1999)].

Taken together, there is evidence that convergent signal transduction pathways of the $5-\mathrm{HT}_{4(\mathrm{a})}$ and $\mu$-opioid receptors possibly regulate antagonistically the formation and stabilisation of the respiratory system. 


\subsection{The opioid-induced depression of the respiratory activity compensated by 8-OH-DPAT without loss of the analgetic effects of the opioid}

The most extensively investigated serotonin receptor isoform in the respiratory system is the $5-\mathrm{HT}_{1 \mathrm{~A}} \mathrm{R}$. The $5-\mathrm{HT}_{1 \mathrm{~A}} \mathrm{R}$ is activated by $8-\mathrm{OH}-\mathrm{DPAT}$ [Middlemiss and Fozard (1983)] which has also an affinity for the 5- $\mathrm{HT}_{7} \mathrm{R}$ [Richter et al. (2003), Sprouse et al. (2004)]. Both receptors operate antagonistically on the adenylyl cyclase $(A C)$ resulting in a decrease $\left(5-\mathrm{HT}_{1 A} \mathrm{R}\right)$ or increase $\left(5-\mathrm{HT}_{7} \mathrm{R}\right)$ of the $[\mathrm{CAMP}]_{\mathrm{i}}$ [Richter et al. (1997), Richter et al. (2003)] (fig. 72). The function of 8-OH-DPAT mediated by activation of the $5-\mathrm{HT}_{1 \mathrm{~A}}$ and $5-\mathrm{HT}_{7}$ receptors in the respiratory system is not fully understood so far. Garner et al. (1989) demonstrated that buspirone, a clinically used anti-anxiety drug with high affinity for the 5-HT $1 \mathrm{~A} R$ [Taylor (1988)], stimulates respiratory activity when administered to anaesthetised cats, whereas Lalley et al. (1994a) showed that 8-OH-DPAT inhibits respiratory activity culminating in apnoea. However, it has also been shown that 8-OH-DPAT and buspirone counteract respiratory disturbances [i.e. apneustic breathing] produced by hypoxia or pentobarbital in anaesthetised cats [Lalley et al. (1994b), Wilken et al. (1997)]. Buspirone was also found to reverse apneustic breathing, which is defined as an abnormal respiratory pattern consisting of a pause at inspiration and prolonged breath holding, in a paediatric patient after surgical resection of an astrocytoma localised in pontomedullary regions [Wilken et al. (1997)]. Furthermore, microinjections of 8-OH-DPAT into the preBötzinger complex (PBC) compensate hypoxia-induced apneustic breathing in cats [Richter et al. (1999)]. Apnoea induced by the N-methyl-D-aspartate receptor antagonist dizocilpine was counteracted by 8-OH-DPAT [Sahibzada et al. (1999)], and both 8-OH-DPAT and buspirone restored breathing to normal levels in animals subjected to spinal cord injury [Teng et al. (1999)]. Recently, it has been shown that opioid-induced apnoea can be compensated by $5-\mathrm{HT}_{1 \mathrm{~A}} \mathrm{R}$ agonists in anaesthetised rats [Sahibzada et al. (2000)].

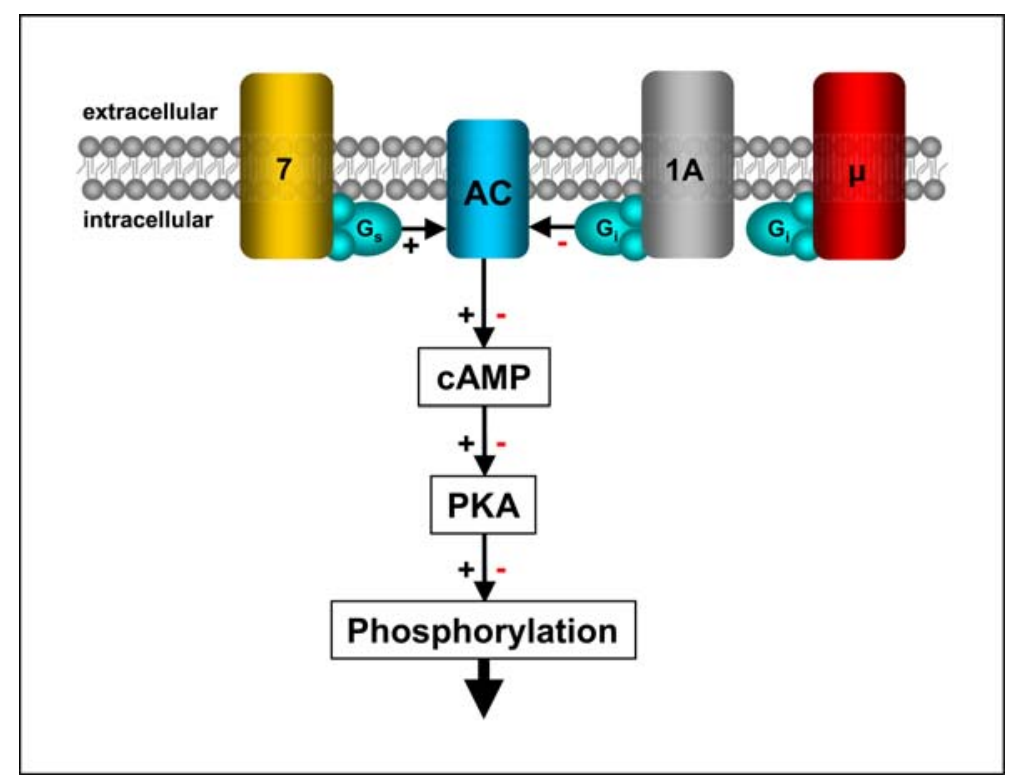

Figure 72. Signal transduction pathways of the $5-\mathrm{HT}_{1 \mathrm{~A}}, \mathbf{5}-\mathrm{HT}_{7}$, and $\mu$-opioid receptors: abbreviations: adenylyl cyclase (AC), cyclic adenosine $5^{\prime}, 3^{\prime}$-monophosphate (cAMP), protein kinase A (PKA), serotonin 7 receptor (7), serotonin $1 A$ receptor $(1 \mathrm{~A})$, $\mu$-opioid receptor $(\mu)$, stimulating or inhibitory hetero-trimeric guanine-nucleotide-binding protein $\left(\mathrm{G}_{\mathrm{s}}\right.$ or $\left.\mathrm{G}_{\mathrm{i}}\right)$.

However, no convincible molecular mechanism or functional model exists so far, which could explain the effects of $8-\mathrm{OH}-\mathrm{DPAT}$. The purpose of this study was to 
analyse whether the $5-\mathrm{HT}_{7} \mathrm{R}$ is expressed in the PBC and whether the $5-\mathrm{HT}_{7} \mathrm{R}$ is coexpressed with the $5-\mathrm{HT}_{1 \mathrm{~A}} \mathrm{R}$ and $\mu$-opioid receptor ( $\mu$-OR). Furthermore, it was investigated whether the $5-\mathrm{HT}_{7} \mathrm{R}$ is involved in the compensation of the opioid-induced depression using 8-OH-DPAT [Sahibzada et al. (2000)], and finally whether or not the analgesia caused by the opioid continues.

The immunohistochemistry (see 3.4.1.) and the single-cell RT-PCR analysis (see 3.4.2.) revealed that the $5-\mathrm{HT}_{1}, 5-\mathrm{HT}_{7}$ and $\mu$-opioid receptors are strongly coexpressed in PBC neurones. These findings suggest that the signal transduction pathways of these receptors are possibly co-existent in inspiratory neurones within the PBC (fig. 72) as was previously shown for the 5- $\mathrm{HT}_{4(\mathrm{a})}$ and $\mu$-opioid receptors [Manzke et al. (2003)]. Both the 5- $\mathrm{HT}_{1 \mathrm{~A}} \mathrm{R}$ and the $\mu$-opioid receptor ( $\mu$-OR) decrease the $[\mathrm{cAMP}]_{\mathrm{i}}$. A decrease of the $[\mathrm{CAMP}]_{\mathrm{i}}$ is associated with a decrease of the respiratory activity [Ballanyi et al. (1997)]. Due to the fact that 8-OH-DPAT do also activate the $5-\mathrm{HT}_{7} \mathrm{R}$ [Sprouse et al. (2004)] resulting in an increase of the [cAMP], stimulation of the $5-\mathrm{HT}_{7} \mathrm{R}$ might compensate the $\mu$-opioid and $5-\mathrm{HT}_{1 \mathrm{~A}}$ receptor-mediated [cAMP] i- $^{-}$ decrease to recover the respiratory activity (fig. 72).

The effects on the breathing pattern due to a systemic application of 8-OH-DPAT were analysed in anaesthetised Sprague-Dawley rats. The application of 8-OH-DPAT increased the respiratory minute volume (RMV). Subsequent injection of the $5-H T_{1 A} R$ antagonist WAY 100635 blocked these effects and the breathing activity returned to baseline levels (see 3.4.3.). The injection of WAY 100635 alone did not have a significant effect on the baseline breathing, but the subsequent injection of $8-\mathrm{OH}-$ DPAT failed to evoke a stimulating effect. In contrast, after intravenous injection of the antagonist SB 269970, specific for the 5- $\mathrm{HT}_{7} \mathrm{R}$ [Lovell et al. (2000)], systemic application of 8-OH-DPAT still increased the RMV. The in-vivo experiments using a fully intact animal indicated that there were no significant systemic effects on the breathing pattern due to $5-\mathrm{HT}_{7} \mathrm{R}$ activation concluding that stimulation of the respiratory activity by $8-\mathrm{OH}-\mathrm{DPAT}$ is predominantly mediated through activation of the 5 $\mathrm{HT}_{1 \mathrm{~A}} \mathrm{R}$.

Due to the excitatory effects of 8-OH-DPAT on the breathing activity, it was analysed whether 8-OH-DPAT recovers the opioid-induced depression of the respiratory activity [Sahibzada et al. (2000)] and whether the opioid-induced analgesia continues. Application of the $\mu$-opioid receptor agonist fentanyl led to apnoea in which the tail-flick response (TFR) was abolished. The respiratory activity recovered within 5 min after application of 8-OH-DPAT almost to the baseline activity, while the TFR was still abolished. The additional application of the opioid receptor antagonist naloxone further increased the RMV to control levels in which the TFR was reestablished and was even in two of six experiments prolonged (see 3.4.4.).

Since $5-\mathrm{HT}_{1 \mathrm{~A}}$ and $\mu$-opioid receptors decrease the $[\mathrm{cAMP}]_{i}$ and the $5-\mathrm{HT}_{7} \mathrm{R}$ did not show any significant effects on breathing pattern after systemic application of $8-\mathrm{OH}-$ DPAT, the recovery of the respiratory activity by activation of the $5-\mathrm{HT}_{1 \mathrm{~A}} \mathrm{R}$ suggests a more complex effect on the network level. 5- $\mathrm{HT}_{1 \mathrm{~A}} \mathrm{R}$ agonists, such as 8-OH-DPAT and buspirone, are known to compensate apneustic breathing [Lalley et al. (1994b), Pierrefiche et al. (1998), Wilken et al. (1997)]. It has been shown that microinjections of $\mathrm{GABA}_{\mathrm{A}}$ and glycine receptor antagonists (bicuculline or strychnine) into the bilateral PBC of anaesthetised cats result in apneustic pattern of breathing which was caused by an incomplete blockade of synaptic inhibition [Pierrefiche et al. (1998)]. This inhibition of synaptic inhibition ('disinhibition ') results in a perpetuated excitation 
of respiratory neurones (depolarisation). Activation of $5-\mathrm{HT}_{1 \mathrm{~A}} \mathrm{R}$ by application of 8$\mathrm{OH}$-DPAT leads to activation of a persistent $\mathrm{K}^{+}$-current [Lalley et al. (1994a)]. The resulting hyperpolarisation of the membrane leads to postsynaptic inhibitory effects on respiratory neurones which compensate the disinhibition-induced depolarisation. This compensation finally restores rhythmic respiratory activity [Pierrefiche et al. (1998)]. This is in accordance with studies which described depressant effects on respiratory neurones induced by activation of the 5- $\mathrm{HT}_{1 \mathrm{~A}} \mathrm{R}$ [Pierrefiche et al. (1998), Richter et al. (1996), Richter et al.(1999)].

However, the main question unsolved is how does an activation of $5-H T_{1 A} R$ overcome opioid-induced depression of the respiratory activity. Büsselberg et al. (2001) demonstrated that the blockade of glycine receptors, caused by systemic application of strychnine, the group of post-inspiratory neurones shifted their onset of discharge into the inspiratory phase. Consequently, the post-inspiratory phase failed and the rhythm changed from a three-phase cycle [inspiration $(I) \rightarrow$ post-inspiration $(p-I) \rightarrow e x-$ piration $(E)$ ] to a faster two-phased cycle $(I \rightarrow E)$. A working hypothesis which could explain the effects of 8-OH-DPAT is based on this phase-shifting phenomenon. The model implies that 5- $\mathrm{HT}_{1 \mathrm{~A}}$ receptors are variably expressed on different types of respiratory neurones particularly on early-inspiratory and post-inspiratory neurones. The activation of the $5-\mathrm{HT}_{1 \mathrm{~A}} \mathrm{R}$ would mainly inhibit the activity of the early-inspiratory and post-inspiratory neurones that their inhibitory action ceases to exist (disinhibition). This effect would enable the respiratory network to reconfigure in which the breathing pattern switches from the three-phase to the two-phase cycle. The early-inspiratory neurones shift their onset discharge into late-inspiratory neurones (fig. 73).

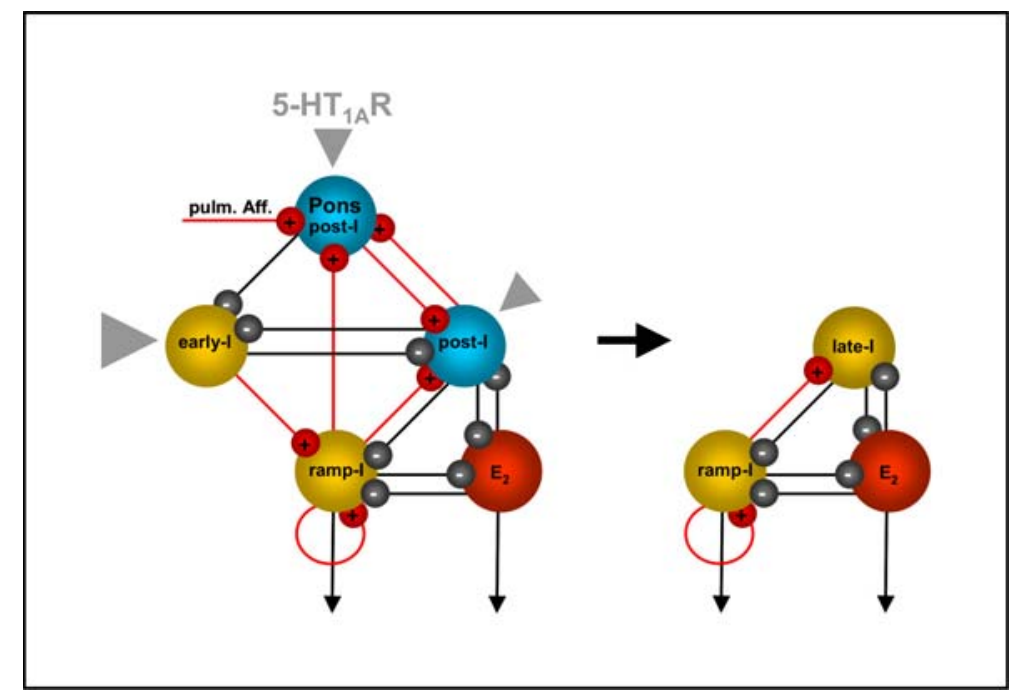

Figure 73. Phase-shifting induced by activation of 5- $\mathrm{HT}_{1 \mathrm{~A}}$ receptors: on the left side: the respiratory network consisting of early-I, post-I, ramp-I, and $E_{2}$ neurones generating a three-phase cycle based on synaptic inhibition. On the right side: the respiratory network producing two-phase cycles after inhibition of the early-I and post-I neurones caused by activation of the 5- $\mathrm{HT}_{1 \mathrm{~A}}$ receptor. Abbreviations: early-inspiratory neurones (early-I), late-inspiratory neurones (late-I), ramp-inspiratory neurones (ramp-I), post-inspiratory neurones (post-I), expiratory neurones $\left(E_{2}\right)$.

The modulatory effect on respiratory neurones is possibly caused by a $5-H_{1 A} R$ mediated modulation of phosphorylation levels of glycine receptors (GlyR) which are mainly responsible for the inhibition within the respiratory network. 5- $\mathrm{HT}_{1 \mathrm{~A}}$ receptors are negatively coupled to the adenylyl cyclase (AC). The activation of the $5-H T_{1 A} R$ results in a decrease of the [CAMP] $]_{i}$ leading to a decrease of the protein kinase $A$ (PKA) activity. The resulting decrease of the PKA-mediated phosphorylation level of GlyR 
would cause a slower deactivation of GlyR [Gentet and Clemens (2002)] which finally would enhance inhibitory postsynaptic potentials (IPSPS) stabilising the respiratory rhythm of the network without phase-shifting.

Another possibility to explain the 8-OH-DPAT effects based on interactions of the serotonin and opioid systems as discussed by Sahibzada et al. (2000). The development study (see 3.3.) provided evidences that both neurotransmitter systems are closely associated. It has been shown that blockade of the serotonin biosynthesis restored opioid-induced depression of $\mathrm{CO}_{2}$-stimulated respiration and reduced opioidinduced respiratory depression observed during ventilation with normal levels of inspired $\mathrm{CO}_{2}$ [Florez et al. (1972)]. Furthermore, activation of presynaptically localised $5-\mathrm{HT}_{1 \mathrm{~A}} \mathrm{R}$ (autoreceptors) inhibit the activity of serotonergic raphé nucleus discharge [Jacobs and Azmitia (1992), Trulson and Arasteh (1986), Veasey et al. (1995)] and probably the release of serotonin at target sites which are innervated by the raphé nuclei. Due to the fact that neurones of the raphé nuclei innervate respiratory centres [Lindsey et al. (1998)] and raphé neurones can cause depression of respiration and apnoea [Lalley et al. (1997)], selective activation of 5-HT 1 A-autoreceptors by $8-\mathrm{OH}$-DPAT possibly restores respiratory activity in this way.

The clinical importance of 8-OH-DPAT is not only reflected by its ability to recover respiratory disturbances like apneustic breathing [Lalley et al. (1994b), Pierrefiche et al. (1998), Wilken et al. (1997)] or opioid-induced respiratory depression [Sahibzada et al. (2000)], but additionally by the remarkable effect that the opioid-induced analgesia after 8-OH-DPAT application remained unaffected. In combination of 5- $\mathrm{HT}_{1 \mathrm{~A}} \mathrm{R}$ agonists with opioids, it has been demonstrated that, if $5-\mathrm{HT}_{1 \mathrm{~A}}$ receptors within the brainstem are blocked by injection of the 5- $\mathrm{HT}_{1 \mathrm{~A}} \mathrm{R}$-antagonist WAY 100635 into the fourth ventricle, the anti-nociceptive effect of fentanyl was attenuated [Clarke and Ward (2000)], whereas the action of systemic application of fentanyl was not diminished by intrathecal administration of a $5-\mathrm{HT}_{1 \mathrm{~A}} \mathrm{R}$ blocker. In contrast, systemic application of the $\alpha_{2}$-adrenoceptor-antagonist RX 821002, which also exhibits high affinity for the 5- $\mathrm{HT}_{1 \mathrm{~A}} \mathrm{R}$ [Clarke and Harris (2002)], did not affect the anti-nociceptive effect of intravenous-injected fentanyl. These data suggest that $5-\mathrm{HT}_{1 \mathrm{~A}}$ receptors are mainly involved in the bulbospinal mediation of opioid-induced anti-nociception. On the other hand, most of the clinical relevant analgetic effects of opioids are due to action on spinal cord level [Clarke et al. (1998)], and bulbospinal pathways are only involved at high opioid concentrations which do not play a predominant role in normal clinical situations. Another explanation for the continuity of opioid-induced analgesia based on possible convergent signal transduction pathways of $5-\mathrm{HT}_{1 \mathrm{~A}}, 5-\mathrm{HT}_{7}$, and $\mu-$ opioid receptors in dorsal horn neurones. Immunohistochemical analysis (see 3.4.1.) revealed that $5-\mathrm{HT}_{1 \mathrm{~A}}, 5-\mathrm{HT}_{7}$, and $\mu$-opioid receptors are co-expressed within the dorsal horn in which the expression of the $5-\mathrm{HT}_{7} \mathrm{R}$ is lower. The $5-\mathrm{HT}_{1 \mathrm{~A}}$ and $\mu$-opioid receptors possibly operate synergistically on spinal cord level to inhibit the PKA (fig. 72). Since $5-\mathrm{HT}_{7}$ receptors are lower expressed, it is assumed that the inhibitory effects of $5-\mathrm{HT}_{1 \mathrm{~A}}$ and $\mu$-opioid receptors are not essentially affected. This would be in accordance with the findings that the tail-flick latency was in some cases of the invivo experiments even prolonged after blockade of the $\mu$-opioid receptors which might be due to $5-\mathrm{HT}_{1 \mathrm{~A}} \mathrm{R}$ action (see 3.4.4.). However, conflicting data exist regarding the interaction of 5- $\mathrm{HT}_{1 \mathrm{~A}} \mathrm{R}$-agonists and opioids as far as nociception is concerned. $5-\mathrm{HT}_{1 \mathrm{~A}} \mathrm{R}$-agonists have been reported to act augmenting [Clarke and Ward (2000), Clarke et al. (1996), Clarke et al. (1998), Millan et al. (1989)] or attenuating [Galeotti et al. (1997)] on nociception, while others report no influence [Millan (1994)]. The 
exact mechanism of $5-\mathrm{HT}_{1 \mathrm{~A}}$ and $\mu$-opioid receptor interaction is still unclear and has to be elucidated.

In conclusion, activation of $5-\mathrm{HT}_{1 \mathrm{~A}}$ receptors by 8-OH-DPAT is a powerful tool to prevent opioid-induced respiratory depression without loss of analgesia. The recovery of respiratory activity seems not to result from $8-\mathrm{OH}$-DPAT-mediated effects on $\mathrm{G}_{\mathrm{s}}$ coupled $5-\mathrm{HT}_{7}$ receptors. As $5-\mathrm{HT}_{1 \mathrm{~A}}$ receptors utilise the same signalling cascade as $\mu$-opioid receptors to inhibit the adenylyl cyclase, the rescue phenomenon is hardly to explain by a simple molecular mechanism. More detailed network analyses are required to investigate if there is a specific subpopulation of inhibitory respiratory interneurones that inhibited by 8-OH-DPAT potentially leading to a disinhibition and/or reconfiguration of the neuronal circuits which control breathing.

\subsection{Expression and function of the serotonin $2 A$ and $2 B$ receptor isoforms in the respiratory system}

Serotonin 2 receptors $\left(5-\mathrm{HT}_{2} \mathrm{R}\right)$ are positively coupled to phospholipase C (PLC) through a hetero-trimeric guanine-nucleotide-binding protein $q(\mathrm{Gq})$ which causes intracellular release of diacylglycerol (DAG) and inositol 1, 4, 5-triphosphate $\left(\mathrm{IP}_{3}\right)$, and subsequently an increase of intracellular calcium $\left(\left[\mathrm{Ca}^{2+}\right]_{i}\right)$, and an activation of the protein kinase C (PKC) [Barnes and Sharp (1999), Egan et al. (1998), Martin and Humphrey (1994), Rauser et al. (2001)] (fig. 74).

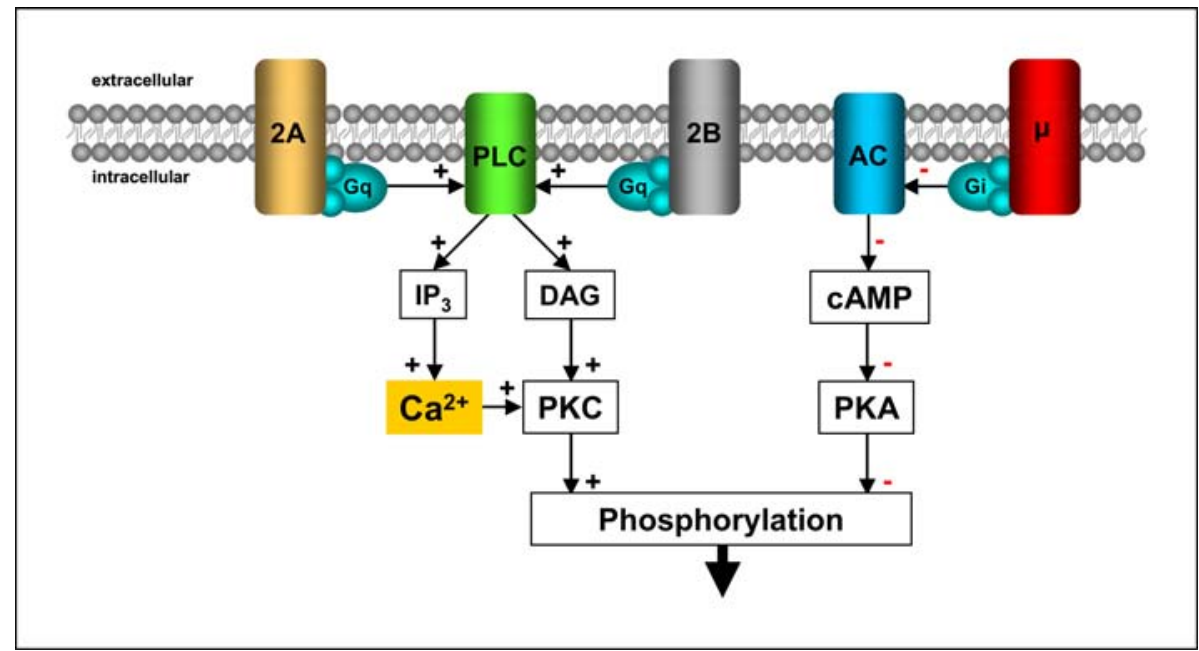

Figure 74. Signal transduction pathways of the 5- $\mathrm{HT}_{2 \mathrm{~A}}, \mathbf{5 -}-\mathrm{HT} \mathrm{T}_{2 \mathrm{~B}}$, and $\mu$-opioid receptors: abbreviations: serotonin $2 \mathrm{~A}$ receptor $(2 \mathrm{~A})$, serotonin $2 \mathrm{~B}$ receptor $(2 \mathrm{~B})$, phospholipase $\mathrm{C}$ (PLC), inositol 1, 4, 5triphosphate $\left(\mathrm{IP}_{3}\right)$, diacylglycerol (DAG), protein kinase $\mathrm{C}(\mathrm{PKC})$, hetero-trimeric guanine-nucleotidebinding protein $q(G q), \mu$-opioid receptor $(\mu)$, adenylyl cyclase $(A C)$, cyclic adenosine $5^{\prime}, 3^{\prime}$-monophosphate (CAMP), protein kinase A (PKA), inhibitory hetero-trimeric guanine-nucleotide-binding protein $(\mathrm{Gi})$.

It has been shown that exogenous applications of agonists specific for the $5-\mathrm{HT}_{2 \mathrm{~A}} \mathrm{R}$ exert an excitatory effect on respiratory activity both in in-vitro [Onimaru et al. (1998)] and in anaesthetised cats [Lalley et al. (1995)]. Excitatory effects mediated by activation of $5-\mathrm{HT}_{2 \mathrm{~A}} \mathrm{R}$ have also been demonstrated in various regions of the central nervous system such as cortex [Araneda and Andrade (1991), Marek and Aghajanian (1996)]. On cellular level, ionophoretical application of $5-\mathrm{HT}_{2 \mathrm{~A}} \mathrm{R}$-agonists like $\alpha$-methyl-5-HT depolarises membrane potential and increases action potential frequency in respiratory neurones [Lalley et al. (1995)]. Bath-application of $5-\mathrm{HT}_{2 \mathrm{~A}} \mathrm{R}$-agonists in 
the perfused brainstem-spinal cord preparation results in an increase of respiratory activity [Onimaru et al. (1998)] as well as in the rhythmic slice-preparation [Al-Zubaidy et al. (1996)]. Since inhibition of the PKC depresses neuronal activity [Haji et al. (1996), Richter et al. (1997)], pharmacological blockade of $5-\mathrm{HT}_{2 \mathrm{~A}} \mathrm{R}$ results in a decrease of respiratory activity.

$5-\mathrm{HT}_{2 \mathrm{~B}}$ receptors possibly operate on the same signal transduction pathway as 5$\mathrm{HT}_{2 \mathrm{~A}}$ receptors (fig. 74) suggesting that, if the $5-\mathrm{HT}_{2 \mathrm{~B}} \mathrm{R}$ is expressed in neurones of the respiratory system, its activation would also stimulate the respiratory activity. However, the expression and function of the $5-\mathrm{HT}_{2 \mathrm{~B}} \mathrm{R}$ in the respiratory system has not been investigated so far. The purpose of this study was therefore to address the question of whether the $5-\mathrm{HT}_{2 \mathrm{~B}} \mathrm{R}$ is expressed in the respiratory system and whether the $5-\mathrm{HT}_{2 \mathrm{~B}} \mathrm{R}$ is co-expressed with the $5-\mathrm{HT}_{2 \mathrm{~A}} \mathrm{R}$. Furthermore, it was tested whether the predicted excitatory action of both receptors can be utilised to treat opioid-induced respiratory depression.

RT-PCR analysis and immunohistochemistry (see 3.5.1.) indicated that the $5-\mathrm{HT}_{2 \mathrm{~B}} \mathrm{R}$ is expressed in the preBötzinger complex (PBC) and is also strongly co-expressed with the $5-\mathrm{HT}_{2 \mathrm{~A}} \mathrm{R}$. However, physiological experiments using an anaesthetised fully intact animal preparation (see 3.5.2.) did not reveal any systemically-evoked longerlasting excitatory effects neither for the $5-\mathrm{HT}_{2 \mathrm{~A}} \mathrm{R}$ nor for the $5-\mathrm{HT}_{2 \mathrm{~B}} \mathrm{R}$. Furthermore, all attempts to recover opioid-induced respiratory depression by selective activation of both receptors failed.

Recently, it has been demonstrated that activation of $5-\mathrm{HT}_{2 \mathrm{~A}}$ and $5-\mathrm{HT}_{2 \mathrm{C}}$ receptors using the agonist DOI [1-(2,5-dimethoxy-4-iodophenyl)-2-aminopropane] even caused mainly depressant respiratory effects in conscious newborn and adult rats [Cayetanot et al. (2001), Cayetanot et al. (2002)].

These findings are contrary to the previously described excitatory effects of the 5$\mathrm{HT}_{2 \mathrm{~A}} \mathrm{R}$ [Lalley et al. (1995), Onimaru et al. (1998)].

Taken together, there are three different actions of $5-\mathrm{HT}_{2}$ receptors on respiratory activity described so far:

(i) excitatory effects in the slice-preparation [Al-Zubaidy et al. (1996)], in the perfused brainstem-spinal cord preparation [Onimaru et al. (1998)], and on single-cell level in-vivo [Lalley et al. (1995)],

(ii) no longer-lasting effects in anaesthetised rats (see 3.5.2.), and

(iii) depressive effects in conscious rats [Cayetanot et al. (2002)].

These contradictory findings are possibly caused by differences in species, experimental approach, anaesthetic regimen, or drug dosage. At presence, the action of 5$\mathrm{HT}_{2 \mathrm{~A}}$ and $5-\mathrm{HT}_{2 \mathrm{~B}}$ receptors within the neuronal respiratory network remains unclear. Excitatory effects of the 5- $\mathrm{HT}_{2 \mathrm{~A}} \mathrm{R}$ observed on single-cell level [Lalley et al. (1995)] probably not reflect its action within the network. More detailed analyses of the expression and function of $5-\mathrm{HT}_{2 \mathrm{~A}}$ and $5-\mathrm{HT}_{2 \mathrm{~B}}$ receptors in different subpopulations of respiratory neurones (inspiratory, post-inspiratory, and expiratory) are required to hypothesise an appropriate functional model. 


\section{Literature}

Abbott C, Povey S: 'Somatic Cell Hybrids'. IRL Press, Oxford 1995

Akil H, Liebeskind JC (1975): Monoaminergic mechanisms of stimulation-produced analgesia. Brain Res $\underline{94}, 279$ - 296

Akil H, Mayer DJ (1972): Antagonism of stimulation-produced analgesia by p-CPA, a serotonin synthesis inhibitor. Brain Res $\underline{44}, 692$ - 697

Akil H, Meng F, Mansour A, Thompson R, Xie GX, Watson S (1996): Cloning and characterization of multiple opioid receptors. NIDA Res Monogr $\underline{161}, 127$ - 140

Alheid GF, Gray PA, Jiang MC, Feldman JL, McCrimmon DR (2002): Parvalbumin in respiratory neurons of the ventrolateral medulla of the adult rat. J Neurocytol $\underline{31}$, $693-717$

Altman J, Bayer SA: 'Atlas of prenatal rat brain development '. CRC Press, Ann Arbor 1995

Al-Zubaidy ZA, Erickson RL, Greer JJ (1996): Serotonergic and noradrenergic effects on respiratory neural discharge in the medullary slice preparation of neonatal rats. Pflugers Arch 431, 942 - 949

Andrade R, Nicoll RA (1987): Pharmacologically distinct actions of serotonin on single pyramidal neurones of the rat hippocampus recorded in vitro. J Physiol $\underline{394}$, $99-124$

Araneda R, Andrade R (1991): 5-Hydroxytryptamine 2 and 5-hydroxytryptamine 1A receptors mediate opposing responses on membrane excitability in rat association cortex. Neuroscience $\underline{40}, 399$ - 412

Arnon R: Immunochemistry of enzymes. In 'The Antigens'. Academic Press, New York 1973, 88 - 159

Artigas F, Romero L, de Montigny C, Blier P (1996): Acceleration of the effect of selected antidepressant drugs in major depression by $5-\mathrm{HT} 1 \mathrm{~A}$ antagonists. Trends Neurosci $\underline{19}, 378$ - 383

Aspenstrom P (1999a): Effectors for the Rho GTPases. Curr Opin Cell Biol 11, 95 102

Aspenstrom P (1999b): The Rho GTPases have multiple effects on the actin cytoskeleton. Exp Cell Res $\underline{246}, 20$ - 25

Bach T, Syversveen T, Kvingedal AM, Krobert KA, Brattelid T, Kaumann AJ, Levy FO (2001): 5-HT4(a) and 5-HT4(b) receptors have nearly identical pharmacology and are both expressed in human atrium and ventricle. Naunyn Schmiedebergs Arch Pharmacol $\underline{363}, 146-160$ 
Baker LP, Nielsen MD, Impey S, Metcalf MA, Poser SW, Chan G, Obrietan K, Hamblin MW, Storm DR (1998): Stimulation of type 1 and type $8 \mathrm{Ca2+/calmodulin-}$ sensitive adenylyl cyclases by the Gs-coupled 5-hydroxytryptamine subtype 5-HT7A receptor. J Biol Chem 273, 17469 - 17476

Ballanyi K, Lalley PM, Hoch B, Richter DW (1997): cAMP-dependent reversal of opioid- and prostaglandin-mediated depression of the isolated respiratory network in newborn rats. J Physiol $\underline{504}, 127$ - 134

Bard JA, Zgombick J, Adham N, Vaysse P, Branchek TA, Weinshank RL (1993): Cloning of a novel human serotonin receptor (5-HT7) positively linked to adenylate cyclase. J Biol Chem 268, 23422 - 23426

Barnes NM, Sharp T (1999): A review of central 5-HT receptors and their function. Neuropharmacology $\underline{38}, 1083$ - 1152

Batteiger B, Newhall WJ, Jones RB (1982): The use of Tween 20 as a blocking agent in the immunological detection of proteins transferred to nitrocellulose membranes. $\mathrm{J}$ Immunol Methods $\underline{55}, 297$ - 307

Beisiegel U (1986): Protein blotting. Electrophoresis $\underline{7}, 1$ - 18

Bender E, Pindon A, van Oers I, Zhang YB, Gommeren W, Verhasselt P, Jurzak M, Leysen J, Luyten W (2000): Structure of the human serotonin 5-HT4 receptor gene and cloning of a novel 5-HT4 splice variant. J Neurochem $\underline{74}, 478$ - 489

Bianchi AL, Denavit-Saubie M, Champagnat J (1995): Central control of breathing in mammals: neuronal circuitry, membrane properties, and neurotransmitters. Physiol Rev $\underline{75}, 1$ - 45

Bickmeyer U, Heine M, Manzke T, Richter DW (2002): Differential modulation of I(h) by 5 -HT receptors in mouse CA1 hippocampal neurons. Eur J Neurosci 16, 209 - 218

Blondel O, Gastineau M, Dahmoune Y, Langlois M, Fischmeister R (1998): Cloning, expression, and pharmacology of four human 5-hydroxytryptamine 4 receptor isoforms produced by alternative splicing in the carboxyl terminus. J Neurochem $\underline{70}$, $2252-2261$

Bockaert J, Sebben M, Dumuis A (1990): Pharmacological characterization of 5hydroxytryptamine 4 (5-HT4) receptors positively coupled to adenylate cyclase in adult guinea pig hippocampal membranes: effect of substituted benzamide derivatives. Mol Pharmacol 37, 408 - 411

Borman RA, Burleigh DE (1993): Evidence for the involvement of a 5-HT4 receptor in the secretory response of human small intestine to 5- $\mathrm{HT}$. Br J Pharmacol 110, 927 928

Borman RA, Burleigh DE (1996): Human colonic mucosa possesses a mixed population of 5-HT receptors. Eur J Pharmacol 309, 271 - 274 
Budhoo MR, Harris RP, Kellum JM (1996): 5-Hydroxytryptamine-induced Cltransport is mediated by $5-\mathrm{HT} 3$ and $5-\mathrm{HT} 4$ receptors in the rat distal colon. Eur $\mathrm{J}$ Pharmacol 298, 137 - 144

Büsselberg D, Bischoff AM, Paton JF, Richter DW (2001): Reorganisation of respiratory network activity after loss of glycinergic inhibition. Pflügers Arch $\underline{441}$, $444-449$

Büsselberg D, Bischoff AM, Richter DW (2003): A combined blockade of glycine and calcium-dependent potassium channels abolishes the respiratory rhythm. Neuroscience $\underline{122}, 831$ - 41

Bonham AC (1995): Neurotransmitters in the CNS control of breathing. Respir Physiol 101, 219 - 230

Burnette WN (1981): Western blotting: Electrophoretic transfer of proteins from sodium dodecyl sulfate-polyacrylamide gels to unmodified nitrocellulose and radiographic detection with antibody radioiodinated protein A. Anal Biochem 112, 195 203

Butera RJ, Rinzel J, Smith JC (1999): Models of respiratory rhythm generation in the pre-Bötzinger complex. II. Populations of coupled pacemaker neurons. J Neurophysiol $\underline{82}, 398-415$

Cardenas CG, Del Mar LP, Cooper BY, Scroggs RS (1997): 5-HT4 receptors couple positively to tetrodotoxin-insensitive sodium channels in a subpopulation of capsaicin-sensitive rat sensory neurons. J Neurosci 17, 7181 - 7189

Cases O, Vitalis T, Seif I, De Maeyer E, Sotelo C, Gaspar P (1996): Lack of barrels in the somatosensory cortex of monoamine oxidase A-deficient mice: role of a serotonin excess during the critical period. Neuron 16, 297 - 307

Cattaneo E, McKay R (1990): Proliferation and differentiation of neuronal stem cells regulated by nerve growth factor. Nature $\underline{347}, 762$ - 765

Cayetanot F, Gros F, Larnicol N (2001): 5-HT(2A/2C) receptor-mediated hypopnea in the newborn rat: relationship to Fos immunoreactivity. Pediatr Res $\underline{50}, 596$ - 603

Cayetanot F, Gros F, Larnicol N (2002): Postnatal changes in the respiratory response of the conscious rat to serotonin $2 \mathrm{~A} / 2 \mathrm{C}$ receptor activation are reflected in the developmental pattern of fos expression in the brainstem. Brain Res $\underline{942,} 51$ - 57

Ceci A, Baschirotto A, Borsini F (1994): The inhibitory effect of 8-OH-DPAT on the firing activity of dorsal raphe serotoninergic neurons in rats is attenuated by lesion of the frontal cortex. Neuropharmacology $\underline{33}, 709$ - 713

Chavez CJ, Ostrea EM Jr, Stryker JC, Smialek Z (1979): Sudden infant death syndrome among infants of drug-dependent mothers. J Pediatr $\underline{95}, 407$ - 409

Cheng L, Hamaguchi K, Ogawa M, Hamada S, Okado N (1994): PCPA reduces both monoaminergic afferents and nonmonoaminergic synapses in the cerebral cortex. Neurosci Res 19, 111 - 115 
Chernick V, Craig RJ (1982): Naloxone reverses neonatal depression caused by fetal asphyxia. Science 216, 1252 - 1253

Chubakov AR, Gromova EA, Konovalov GV, Sarkisova EF, Chumasov El (1986): The effects of serotonin on the morpho-functional development of rat cerebral neocortex in tissue culture. Brain Res $\underline{369}, 285$ - 297

Claeysen S, Sebben M, Journot L, Bockaert J, Dumuis A (1996): Cloning, expression and pharmacology of the mouse 5-HT(4L) receptor. FEBS Lett $\underline{398}, 19$ - 25

Claeysen S, Joubert L, Sebben M, Bockaert J, Dumuis A (2003): A single mutation in the 5-HT4 receptor (5-HT4-R D100(3.32)A) generates a Gs-coupled receptor activated exclusively by synthetic ligands (RASSL). J Biol Chem 278, 699 - 702

Clarke RW, Ward RE (2000): The role of 5-HT(1A)-receptors in fentanyl-induced bulbospinal inhibition of a spinal withdrawal reflex in the rabbit. Pain 85, 239 - 245

Clarke RW, Harris J (2002): RX 821002 as a tool for physiological investigation of alpha(2)-adrenoceptors. CNS Drug Rev $\underline{8}, 177$ - 192

Clarke RW, Harris J, Houghton AK (1996): Spinal 5-HT-receptors and tonic modulation of transmission through a withdrawal reflex pathway in the decerebrated rabbit. Br J Pharmacol 119, 1167 - 1176

Clarke RW, Parry-Baggott C, Houghton AK, Ogilvie J (1998): The involvement of bulbospinal pathways in fentanyl-induced inhibition of spinal withdrawal reflexes in the decerebrated rabbit. Pain $\underline{78}, 197$ - 207

Clarke RW, Bhandari RN, Leggett J (2001): Opioid and GABA receptors involved in mediation and modulation of tonic and stimulus-evoked inhibition of a spinal reflex in the decerebrated and spinalized rabbit. Neuropharmacology 411, 311 - 320

Coller Ha, Coller BS (1983): Statistical analysis of repetitive subcloning by the limiting dilution technique with a view toward ensuring hybridoma monoclonality. Hybridoma 2, $91-96$

Compan V, Daszuta A, Salin P, Sebben M, Bockaert J, Dumuis A (1996): Lesion study of the distribution of serotonin 5-HT4 receptors in rat basal ganglia and hippocampus. Eur J Neurosci $\underline{8}, 2591$ - 2598

Compan V, Zhou M, Grailhe R, Gazzara RA, Martin R, et al. (2004): Attenuated response to stress and novelty and hypersensitivity to seizures in 5-HT4 receptor knock-out mice. J Neurosci $\underline{24}, 412$ - 419

Connelly CA, Dobbins EG, Feldman JL (1992): Pre-Botzinger complex in cats: respiratory neuronal discharge patterns. Brain Res $\underline{590}, 337$ - 340

Cornea-Hebert V, Riad M, Wu C, Singh SK, Descarries L (1999): Cellular and subcellular distribution of the serotonin 5-HT2A receptor in the central nervous system of adult rat. J Comp Neurol $\underline{409}, 187$ - 209 
Crumpton MJ: Protein antigens: The molecular basis of antigenicity and immunogenicity. In 'The Antigens`. Academic Press, New York 1974, 1 - 78

Dahlström A, Fuxe K (1964): Localization of monoamines in the lower brain stem. Experientia 15, 398 - 399

Deisenhofer J (1981); Crystallographic refinement and atomic models of a human Fc fragment and its complex with fragment B of protein A from Staphylococcus aureus at 2.9- and 2.8-A resolution. Biochemistry 20, $2361-2370$

Denavit-Saubie M, Champagnat J, Ziegelgansberger W (1978): Effects of opiates and methionine-enkephalin on pontine and bulbar respiratory neurones of the cat. Brain Res $\underline{155}, 55$ - 67

Di Pasquale E, Morin D, Monteau R, Hilaire G (1992): Serotonergic modulation of the respiratory rhythm generator at birth: an in vitro study in the rat. Neurosci Lett $\underline{143}$, $91-95$

Dumuis A, Bouhelal R, Sebben M, Cory R, Bockaert J (1988): A nonclassical 5hydroxytryptamine receptor positively coupled with adenylate cyclase in the central nervous system. Mol Pharmacol $\underline{34}, 880$ - 887

Duncan MJ, Short J, Wheeler DL (1999): Comparison of the effects of aging on 5HT7 and 5-HT1A receptors in discrete regions of the circadian timing system in hamsters. Brain Res $\underline{829}, 39$ - 45

Dunn EB, Wolfe JJ (2000): Finding an optimal dose: considerations in accurate opioid dispensing. Vet Hum Toxicol $\underline{42}, 36$ - 38

Duxon MS, Flanigan TP, Reavley AC, Baxter GS, Blackburn TP, Fone KCF (1997): Evidence for the expression of the 5 -HT2B receptor protein in the rat central nervous system. Neuroscience $\underline{76}, 323-329$

Egan C, Herrick-Davis K, Teitler M (1998): Creation of a constitutively activated state of the 5-HT2A receptor by site-directed mutagenesis: revelation of inverse agonist activity of antagonists. Ann N Y Acad Sci $\underline{861}, 136$ - 139

Eglen RM, Wong EH, Dumuis A, Bockaert J (1995): Central 5-HT4 receptors. Trends Pharmacol Sci 16, 391 - 398

Feldman JL, Windhorst U, Anders K, Richter DW (1992): Synaptic interaction between medullary respiratory neurones during apneusis induced by NMDA-receptor blockade in cat. J Physiol $\underline{450}, 303$ - 323

Feldman JL, Smith JC, Liu G (1991): Respiratory pattern generation in mammals: in vitro en bloc analyses. Curr Opin Neurobiol 1, 590 - 594

Feldman JL, Mitchell GS, Nattie EE (2003): Breathing: rhythmicity, plasticity, chemosensitivity. Annu Rev Neurosci 26, 239 - 266 
Flórez J, Hurlé MA: Opioids in respiration and vomiting. In 'Handbook of experimental pharmacology`, Opioids II. Springer-Verlag, New York 1993, 263 - 292

Florez J, Delgado G, Armijo JA (1972): Adrenergic and serotonergic mechanisms in morphine-induced respiratory depression. Psychopharmacologia 24, 258 - 274

Freye E, Latasch L, Portoghese PS (1992): The delta receptor is involved in sufentanil-induced respiratory depression--opioid subreceptors mediate different effects. Eur J Anaesthesiol $\underline{9}, 457$ - 462

Freye E, Schnitzler M, Schenk G (1991): Opioid-induced respiratory depression and analgesia may be mediated by different subreceptors. Pharm Res $\underline{8}, 196$ - 199

Galeotti N, Ghelardini C, Bartolini A (1997): 5-HT1A agonists induce central cholineergic antinociception. Pharmacol Biochem Behav 57, 835 - 841

Garner SJ, Eldridge FL, Wagner PG, Dowell RT (1989): Buspirone, an anxiolytic drug that stimulates respiration. Am Rev Respir Dis $\underline{139}, 946$ - 950

Garratt JC, Crespi F, Mason R, Marsden CA (1991): Effects of idazoxan on dorsal raphe 5-hydroxytryptamine neuronal function. Eur J Pharmacol $\underline{193}, 87$ - 93

Gennis RB: 'Biomembranes. Molecular structure and function` (Springer advanced texts in chemistry). Springer-Verlag, New York 1989

Gershoni JM, Palade GE (1983): Protein blotting: Principles and applications. Anal Biochem 131, 1 - 15

Geurts FJ, De Schutter E, Timmermans JP (2002): Localization of 5-HT2A, 5-HT3, 5HT5A and 5-HT7 receptor-like immunoreactivity in the rat cerebellum. J Chem Neuroanat $\underline{24}, 65-74$

Goding JW: 'Monoclonal antibodies: principles and practice`. Academic Press, New York 1996

Goodman LS, Gilman A: 'The pharmacological basis of therapeutics'. Pergamon Press, New York 1990

Grass D, Pawlowski PG, Hirrlinger J, Papadopoulos N, Richter DW, Kirchhoff F, Hülsmann S (2004): Diversity of functional astroglial properties in the respiratory network. J Neurosci 24, 1358 - 1365

Gray PA, Rekling JC, Bocchiaro CM, Feldman JL (1999): Modulation of respiratory frequency by peptidergic input to rhythmogenic neurons in the preBötzinger complex. Science 286, 1566 - 1568

Gray PA, Janczewski WA, Mellen N, McCrimmon DR, Feldman JL (2001): Normal breathing requires preBötzinger complex neurokinin-1 receptor-expressing neurons. Nat Neurosci $\underline{4}, 927-930$

Greer JJ, Smith JC, Feldman JL (1992): Respiratory and locomotor patterns generated in the fetal rat brain stem-spinal cord in vitro. J Neurophysiol $\underline{67}, 996$ - 999 
Guyenet PG, Wang H (2001): Pre-Bötzinger neurons with preinspiratory discharges "in vivo" express NK1 receptors in the rat. J Neurophysiol 흐, 438 - 46

Guyenet PG, Sevigny CP, Weston MC, Stornetta RL (2002): Neurokinin-1 receptorexpressing cells of the ventral respiratory group are functionally heterogeneous and predominantly glutamatergic. J Neurosci $\underline{22}, 3806$ - 3816

Haji A, Pierrefiche O, Lalley PM, Richter DW (1996): Protein kinase C pathways modulate respiratory pattern generation in the cat. J Physiol $\underline{494}, 297$ - 306

Haji A, Takeda R, Okazaki M (2000): Neuropharmacology of control of respiratory rhythm and pattern in mature mammals. Pharmacol Ther $\underline{86}, 277$ - 304

Hajós M, Richards CD, Szekely AD, Sharp T (1998): An electrophysiological and neuroanatomical study of the medial prefrontal cortical projection to the midbrain raphe nuclei in the rat. Neuroscience $\underline{87}, 95$ - 108

Hajós M, Hajós-Korcsok E, Sharp T (1999): Role of the medial prefrontal cortex in 5$\mathrm{HT} 1 \mathrm{~A}$ receptor-induced inhibition of $5-\mathrm{HT}$ neuronal activity in the rat. Br $\mathrm{J}$ Pharmacol $\underline{126}, 1741-1750$

Hamon M: 'Serotonergic Neurons and 5-HT Receptors in the CNS'. Springer-Verlag, Berlin 1997

Haslam RJ, Davidson MM, Desjardins JV (1978): Inhibition of adenylate cyclase by adenosine analogues in preparations of broken and intact human platelets. Evidence for the unidirectional control of platelet function by cyclic AMP. Biochem J $\underline{176}, 83-$ 95

Harboe N, Inglid A: Immunization, isolation of immunoglobulins, estimation of antibody titre: In 'A Manual Quantitative Immunoelectrophoresis'. Blackwell Scientific Publications, London 1973, 161 - 164

Haring JH, Yan W (1993): Effects of neonatal serotonin depletion on the development of rat dentate granule cells. Soc Neurosci Abstr 19, 673

Harlow E, Lane D: 'Antibodies: A laboratory manual'. Cold Spring Harbor Press, New York 1988

Haydon PG, McCobb DP, Kater SB (1987): The regulation of neurite outgrowth, growth cone motility, and electrical synaptogenesis by serotonin. J Neurobiol $\underline{18}$, $197-215$

Hedlund PB, Danielson PE, Thomas EA, Slanina K, Carson MJ, Sutcliffe JG (2003): No hypothermic response to serotonin in $5-\mathrm{HT} 7$ receptor knockout mice. Proc Natl Acad Sci 100, 1375 - 1380

Heidmann DE, Metcalf MA, Kohen R, Hamblin MW (1997): Four 5hydroxytryptamine7 (5-HT7) receptor isoforms in human and rat produced by alternative splicing: species differences due to altered intron-exon organization. $\mathrm{J}$ Neurochem $\underline{68}, 1372$ - 1381 
Heidmann DE, Szot P, Kohen R, Hamblin MW (1998): Function and distribution of three rat 5-hydroxytryptamine7 (5-HT7) receptor isoforms produced by alternative splicing. Neuropharmacology $\underline{37}, 1621$ - 1632

Heine M, Ponimaskin E, Bickmeyer U, Richter DW (2002): 5-HT-receptor-induced changes of the intracellular cAMP level monitored by a hyperpolarization-activated cation channel. Pflugers Arch $\underline{443}, 418$ - 426

Herz A, Millan MJ (1990): Opioids and opioid receptors mediating antinociception at various levels of the neuraxis. Physiol Bohemoslov 39, 395 - 401

Hilaire G, Duron B (1999): Maturation of the mammalian respiratory system. Physiol Rev $\underline{79}, 325-360$

Hilaire G, Morin D, Lajard AM, Monteau R (1993): Changes in serotonin metabolism may elicit obstructive apnoea in the newborn rat. J Physiol $\underline{466}, 367$ - 381

Hole K (1972): The effects of cyproheptadine, methysergide, BC 105 and reserpine on brain 5-hydroxytryptamine and brain growth. Eur J Pharmacol $\underline{19}, 156$ - 159

Howard GC, Bethell DR: 'Basic methods in antibody production and characterization`. CRC Press 2001

Hoyer D, Clarke DE, Fozard JR, Hartig PR, Martin GR, Mylecharane EJ, Saxena PR, Humphrey PP (1994): International Union of Pharmacology classification of receptors for 5-hydroxytryptamine (Serotonin). Pharmacol Rev 46, 157 - 203

Hoyer D, Hannon JP, Martin GR (2002): Molecular, pharmacological and functional diversity of 5-HT receptors. Pharmacol Biochem Behav $\underline{71}, 533$ - 554

Hurley PT, McMahon RA, Fanning P, O’Boyle KM, Rogers M, Martin F (1998): Functional coupling of a recombinant human 5-HT5A receptor to G-proteins in HEK293 cells. Br J Pharmacol 124, 1238 - 1244

Jacobs BL, Azmitia EC (1992): Structure and function of the brain serotonin system. Physiol Rev $\underline{72}, 165$ - 229

Jakeman LB, To ZP, Eglen RM, Wong EH, Bonhaus DW (1994): Quantitative autoradiography of 5-HT4 receptors in brains of three species using two structurally distinct radioligands, [3H]GR113808 and [3H]BIMU-1. Neuropharmacology $\underline{33}$, 1027 - 1038

Jasper JR, Kosaka A, To ZP, Chang DJ, Eglen RM (1997): Cloning, expression and pharmacology of a truncated splice variant of the human 5-HT7 receptor (h5-HT7b). Br J Pharmacol 122, 126 - 132

John NJ, Lew GM, Goya L, Timiras PS (1991): Effects of serotonin on tyrosine hydroxylase and tau protein in a human neuroblastoma cell line. Adv Exp Med Biol $\underline{296}, 69-80$ 
Kaumann AJ, Lynham JA, Brown AM (1996): Comparison of the densities of 5-HT4 receptors, beta 1- and beta 2-adrenoceptors in human atrium: functional implications. Naunyn Schmiedebergs Arch Pharmacol 353, 592 - 595

Kearney JF, Radbruch A, Liesegang B, Rajewsky K (1979): A new mouse myeloma cell line that has lost immunoglobulin expression but permits the construction of antibody-secreting hybrid cell lines. J Immunol 123, 1548 - 1550

Kennett GA, Bright F, Trail B, Baxter GS, Blackburn TP (1996): Effects of the 5-HT2B receptor agonist, BW 723C86, on three rat models of anxiety. $\mathrm{Br} \mathrm{J}$ Pharmacol $\underline{117}$, 1443 - 1448

Kinney HC, Filiano JJ, White WF (2001): Medullary serotonergic network deficiency in the sudden infant death syndrome: review of a 15-year study of a single dataset. $\mathrm{J}$ Neuropathol Exp Neurol $\underline{60}, 228$ - 247

Kinney HC, Randall LL, Sleeper LA, Willinger M, Belliveau RA, et al. (2003): Serotonergic brainstem abnormalities in Northern Plains Indians with the sudden infant death syndrome. J Neuropathol Exp Neurol $\underline{62}, 1178$ - 1191

Kii Y, Ito T (1997): Effects of 5-HT4-receptor agonists, cisapride, mosapride citrate, and zacopride, on cardiac action potentials in guinea pig isolated papillary muscles. $\mathrm{J}$ Cardiovasc Pharmacol 29, 670 - 675

Knapp RJ, Malatynska E, Collins N, Fang L, Wang JY, et al. (1995): Molecular biology and pharmacology of cloned opioid receptors. FASEB J $\underline{9}, 516$ - 525

Kobilka BK, Frielle T, Collins S, Yang-Feng T, Kobilka TS, Francke U, Lefkowitz RJ, Caron MG (1987): An intronless gene encoding a potential member of the family of receptors coupled to guanine nucleotide regulatory proteins. Nature $\underline{329}, 75$ - 79

Köhler G, Milstein C (1975): Continuous cultures of fused cells secreting antibody of predefined specificity. Nature 256, 495 - 497

Koshiya N, Smith JC (1999): Neuronal pacemaker for breathing visualized in vitro. Nature $\underline{400}, 360$ - 363

Koyama S, Matsumoto N, Murakami N, Kubo C, Nabekura J, Akaike N (2002): Role of presynaptic 5-HT1A and 5-HT3 receptors in modulation of synaptic GABA transmission in dissociated rat basolateral amygdala neurons. Life Sci $\underline{72}$, 375 - 387

Kroeze WK, Kristiansen K, Roth BL (2002): Molecular biology of serotonin receptors structure and function at the molecular level. Curr Top Med Chem 2, 507 - 528

Kronvall G, Messner RP, Williams RC (1970a): Immunochemical studies on the interaction between staphylococcal protein A and gamma-G globulin. J Immunol $\underline{105}$, $1353-1359$

Kronvall G, Grey HM, Williams RC (1970b): Protein A reactivity with mouse immunoglobulins. Structural relationship between some mouse and human immunoglobulins. J Immunol 105, 1116 - 1123 
Kubin L, Davies RO, Pack Al (1998): Control of Upper Airway Motoneurons During REM Sleep. News Physiol Sci 13, 91 - 97

Kyhse-Andersen (1984): Electroblotting of multiple gels: a simple apparatus without tank for rapid transfer of proteins from polyacrylamid to nitrocellulose. J Biochem Biophys Methods 10, 203 - 209

Kyte J, Doolittle RF (1982): A simple method for displaying the hydropathic character of a protein. J Mol Biol 157, 105 - 132

Laemmli UK (1970): Cleavage of structural proteins during the assembly of the head of bacteriophage T4. Nature 227, 680 - 685

Laemmli UK, Favre M (1973): Maturation of the head of bacteriophage T 4. J Mol Biol $\underline{80}, 575-599$

Lalley PM, Bischoff AM, Richter DW (1994a): 5-HT-1A receptor-mediated modulation of medullary expiratory neurones in the cat. J Physiol $\underline{476}, 117-30$

Lalley PM, Bischoff AM, Richter DW (1994b): Serotonin 1A-receptor activation suppresses respiratory apneusis in the cat. Neurosci Lett $\underline{172}, 59$ - 62

Lalley PM, Bischoff AM, Schwarzacher SW, Richter DW (1995): 5-HT2 receptorcontrolled modulation of medullary respiratory neurones in the cat. J Physiol $\underline{487}$, $653-661$

Launay JM, Herve P, Peoc'h K, Tournois C, Callebert J, et al. (2002): Function of the serotonin 5 -hydroxytryptamine $2 \mathrm{~B}$ receptor in pulmonary hypertension. Nat Med $\underline{8}$, $1129-1135$

Layne E: Spectrophotometric and turbidimetric methods for measuring proteins: In 'Guide to protein purification' (Methods Enzymol 182). Academic Press, San Diego 1990, $447-454$

Langlois M, Fischmeister R (2003): 5-HT4 receptor ligands: applications and new prospects. J Med Chem $\underline{46}, 319$ - 344

Lauder JM (1993): Neurotransmitters as growth regulatory signals: role of receptors and second messengers. Trends Neurosci $\underline{16}, 233$ - 240

Lauder JM, Krebs H (1978): Serotonin as a differentiation signal in early neurogenesis. Dev Neurosci $\underline{1}, 15$ - 30

Laver WG, Air GM, Webster RG, Smith-Gill SJ (1990): Epitopes on protein antigens: misconceptions and realities. Cell $\underline{61}, 553$ - 556

Lendahl $U$ (1997): Gene regulation in the formation of the central nervous system. Acta Paediatr Suppl $\underline{422}, 8$ - 11

Lendahl U, Zimmerman LB, McKay RD (1990): CNS stem cells express a new class of intermediate filament protein. Cell $\underline{60}, 585$ - 595 
Lerner RA (1984): Antibodies of predetermined specificity in biology and medicine. Adv Immunol 36, 1 - 44

Lezoualc'h F, Robert SJ (2003): The serotonin 5-HT4 receptor and the amyloid precursor protein processing. Exp Gerontol $\underline{38}, 159$ - 166

Li YW, Guyenet PG (1997): Effect of substance P on C1 and other bulbospinal cells of the RVLM in neonatal rats. Am J Physiol 273, 805 - 813

Lichtman AH, Smith FL, Martin BR (1993): Evidence that the antinociceptive tail-flick response is produced independently from changes in either tail-skin temperature or core temperature. Pain $\underline{55}, 283$ - 295

Lindsay AD, Feldman JL (1993): Modulation of respiratory activity of neonatal rat phrenic motoneurones by serotonin. J Physiol $\underline{461}, 213$ - 233

Lindsey BG, Arata A, Morris KF, Hernandez YM, Shannon R (1998): Medullary raphe neurones and baroreceptor modulation of the respiratory motor pattern in the cat. $\mathrm{J}$ Physiol $\underline{512}, 863-882$

Ling GS, Spiegel K, Lockhart SH, Pasternak GW (1985): Separation of opioid analgesia from respiratory depression: evidence for different receptor mechanisms. J Pharmacol Exp Ther 232, 149 - 155

Ling GS, Simantov R, Clark JA, Pasternak GW (1986): Naloxonazine actions in vivo. Eur J Pharmacol $\underline{129}, 33$ - 38

Lovell PJ, Bromidge SM, Dabbs S, Duckworth DM, Forbes IT, et al. (2000): A novel, potent, and selective 5-HT(7) antagonist: (R)-3-(2-(2-(4-methylpiperidin-1-yl)ethyl) pyrrolidine-1-sulfonyl) phen ol (SB-269970). J Med Chem $\underline{43}, 342$ - 345

Lovenberg TW, Baron BM, de Lecea L, Miller JD, Prosser RA, et al. (1993): A novel adenylyl cyclase-activating serotonin receptor (5-HT7) implicated in the regulation of mammalian circadian rhythms. Neuron 11, 449 - 458

Lowry OH, Rosebrough NJ, Farr AL, Randall RJ (1951): Protein measurement with the folin phenol reagent. J Biol Chem 193, 265 - 275

Lugaresi E, Cirignotta F, Mondini S, Montagna P, Zucconi M (1985): Sleep-related respiratory disorders. Ital J Neurol Sci $\underline{6}, 389$ - 399

Mansour A, Khachaturian H, Lewis ME, Akil H, Watson SJ (1988): Anatomy of CNS opioid receptors. Trends Neurosci 11, 308 - 314

Manzke T, Schwarzacher S, Bickmeyer U, Richter DW (2002): Distribution of 5-HT4a and 5-HT7 receptors in rodent brain. FENS Forum Abstr. 1, 77 (abstr. 022.9)

Manzke T, Guenther U, Ponimaskin EG, Haller M, Dutschmann M, Schwarzacher S, Richter DW (2003): 5-HT4(a) receptors avert opioid-induced breathing depression without loss of analgesia. Science $\underline{301}, 226$ - 229 
Marek GJ, Aghajanian GK (1996): LSD and the phenethylamine hallucinogen DOI are potent partial agonists at 5-HT2A receptors on interneurons in rat piriform cortex. J Pharmacol Exp Ther 278, 1373 - 1382

Marshall CJ (1999): Small GTPases and cell cycle regulation. Biochem Soc Trans $\underline{27}, 363-370$

Martin GR, Humphrey PP (1994): Receptors for 5-hydroxytryptamine: current perspectives on classification and nomenclature. Neuropharmacology $\underline{33}, 261$ - 273

Matthes HW, Maldonado R, Simonin F, Valverde O, Slowe S, et al. (1996): Loss of morphine-induced analgesia, reward effect and withdrawal symptoms in mice lacking the mu-opioid-receptor gene. Nature $\underline{383}, 819$ - 823

McAllister-Williams RH, Kelly JS (1995): The modulation of calcium channel currents recorded from adult rat dorsal raphe neurones by 5-HT1A receptor or direct G-protein activation. Neuropharmacology $\underline{34}, 1491$ - 1506

Messam CA, Hou J, Major EO (2000): Coexpression of nestin in neural and glial cells in the developing human CNS defined by a human-specific anti-nestin antibody. Exp Neurol 161, $585-596$

Middlemiss DN, Fozard JR (1983): 8-Hydroxy-2-(di-n-propylamino)-tetralin discriminates between subtypes of the 5-HT1 recognition site. Eur J Pharmacol 90, 151 - 153

Millan MJ (1994): Serotonin and pain: evidence that activation of 5-HT1A receptors does not elicit antinociception against noxious thermal, mechanical and chemical stimuli in mice. Pain $\underline{58}, 45$ - 61

Millan MJ, Bervoets K, Colpaert FC (1989): Apparent hyperalgesic action of the 5HT1A agonist, 8-OH-DPAT, in the rat reflects induction of spontaneous tail-flicks. Neurosci Lett $\underline{107}, 227$ - 232

Miller JH, Azmitia EC (1999): Growth inhibitory effects of a mu opioid on cultured cholinergic neurons from fetal rat ventral forebrain, brainstem, and spinal cord. Brain Res Dev Brain Res 114, 69 - 77

Minsky M (1988): Memoir on Inventing the Confocal Scanning Microscope. Scanning $\underline{10}, 128-138$

Morin D, Hennequin S, Monteau R, Hilaire G (1990): Serotonergic influences on central respiratory activity: an in vitro study in the newborn rat. Brain Res $\underline{535}, 281$ 287

Mujtaba T, Mayer-Proschel M, Rao MS (1998): A common neural progenitor for the CNS and PNS. Dev Biol 200, 1 - 15

Mullis KB, Faloona FA (1987): Specific synthesis of DNA in vitro via a polymerasecatalyzed chain reaction. Methods Enzymol 155, 335 - 350 
Mullis K, Faloona F, Scharf S, Horn G, Erlich H (1986): Specific enzymatic amplification of DNA in vitro: the polymerase chain reaction. Cold Spring Harb Symp Quant Biol 토, 263 - 273

Narita N, Narita M, Takashima S, Nakayama M, Nagai T, Okado N (2001): Serotonin transporter gene variation is a risk factor for sudden infant death syndrome in the Japanese population. Pediatrics 107, 690 - 692

Nebigil CG, Choi DS, Dierich A, Hickel P, Le Meur M, Messaddeq N, Launay JM, Maroteaux L (2000): Serotonin 2B receptor is required for heart development. Proc Natl Acad Sci 97, 9508 - 9513

Nebigil CG, Hickel P, Messaddeq N, Vonesch JL, Douchet MP, Monassier L, Gyorgy $\mathrm{K}$, Matz R, et al. (2001): Ablation of serotonin 5-HT(2B) receptors in mice leads to abnormal cardiac structure and function. Circulation $\underline{103}, 2973$ - 2979

Neugebauer JM: Detergents: An overview: In 'Guide to protein purification` (Methods Enzymol 182). Academic Press, San Diego 1990, 239 - 253

Niu J, Vaiskunaite R, Suzuki N, Kozasa T, Carr DW, Dulin N, Voyno-Yasenetskaya TA (2001): Interaction of heterotrimeric G13 protein with an A-kinase-anchoring protein 110 (AKAP110) mediates CAMP-independent PKA activation. Curr Biol $\underline{11}$, $1686-1690$

Norum JH, Hart K, Levy FO (2003): Ras-dependent ERK activation by the human G(s)-coupled serotonin receptors 5-HT4(b) and 5-HT7(a). J Biol Chem 278, 3098 3104

Onimaru H, Shamoto A, Homma I (1998): Modulation of respiratory rhythm by 5-HT in the brainstem-spinal cord preparation from newborn rat. Pflugers Arch $\underline{435}, 485$ 494

Onimaru H, Homma I (2002): Development of the rat respiratory neuron network during the late fetal period. Neurosci Res 42, 209 - 218

Onimaru H, Homma I (2003): A novel functional neuron group for respiratory rhythm generation in the ventral medulla. J Neurosci $\underline{23}, 1478$ - 1486

Ostrea EM Jr, Ostrea AR, Simpson PM (1997): Mortality within the first 2 years in infants exposed to cocaine, opiate, or cannabinoid during gestation. Pediatrics $\underline{100}$, $79-83$

Ozawa Y, Okado N (2002): Alteration of serotonergic receptors in the brain stems of human patients with respiratory disorders. Neuropediatrics $\underline{33}, 142$ - 149

Page IH (1952): The vascular action of natural serotonin, 5- and 7-hydroxytryptamine and tryptamine. J Pharmacol Exp Ther $\underline{105}$, 58 - 73

Pagliardini S, Ren J, Greer JJ (2003): Ontogeny of the pre-Botzinger complex in perinatal rats. J Neurosci $\underline{23}, 9575$ - 9584 
Palacios JM, Waeber C, Hoyer D, Mengod G (1990): Distribution of serotonin receptors. Ann N Y Acad Sci $\underline{600}, 36$ - 52

Parks CL, Robinson PS, Sibille E, Shenk T, Toth M (1998): Increased anxiety of mice lacking the serotonin1A receptor. Proc Natl Acad Sci $\underline{95}, 10734$ - 10739

Pasternak GW, Childers SR, Snyder SH (1980): Opiate analgesia: evidence for mediation by a subpopulation of opiate receptors. Science 208, 514 - 516

Paton JF, Ramirez JM, Richter DW (1994): Functionally intact in vitro preparation generating respiratory activity in neonatal and mature mammals. Pflugers Arch $\underline{428}$, $250-260$

Paton JF (1996a): The ventral medullary respiratory network of the mature mouse studied in a working heart-brainstem preparation. J Physiol 493, 819 - 831

Paton JF (1996b): A working heart-brainstem preparation of the mouse. J Neurosci Methods $\underline{65}, 63-68$

Paxinos G, Watson C: 'The rat brain in stereotaxic coordinates'. Academic Press, 1986

Peters JH, Baumgarten H: 'Monoclonal Antibodies`. Springer-Verlag, New York 1992

Peterson GL (1977): A simplification of the protein assay method of Lowry, et al. which is more generally applicable. Anal Biochem $\underline{83}, 346-356$

Pilowsky PM, Feldman JL (2001): Identifying neurons in the preBötzinger complex that generate respiratory rhythm: visualizing the ghost in the machine. $\mathrm{J}$ Comp Neurol $\underline{434}, 125-7$

Pierrefiche O, Schwarzacher SW, Bischoff AM, Richter DW (1998): Blockade of synaptic inhibition within the pre-Bötzinger complex in the cat suppresses respiratory rhythm generation in vivo. J Physiol $\underline{509}, 245$ - 254

Pindon A, van Hecke G, van Gompel P, Lesage AS, Leysen JE, Jurzak M (2002): Differences in signal transduction of two 5-HT4 receptor splice variants: compound specificity and dual coupling with Galphas- and Galphai/o-proteins. Mol Pharmacol $\underline{61}, 85-96$

Ponimaskin EG, Schmidt MF, Heine M, Bickmeyer U, Richter DW (2001): 5Hydroxytryptamine 4(a) receptor expressed in Sf9 cells is palmitoylated in an agonistdependent manner. Biochem J 353, 627 - 634

Ponimaskin EG, Profirovic J, Vaiskunaite R, Richter DW, Voyno-Yasenetskaya TA (2002): 5-Hydroxytryptamine 4(a) receptor is coupled to the Galpha subunit of heterotrimeric G13 protein. J Biol Chem 277, 20812 - 20819

Privat A, Gimenez-Ribota M, Ridet JL: 'Morphology of astrocytes`. Oxford University Press 1995, 3 - 22 
Puig MM, Montes A (1998): Opioids: From Receptors to Clinical Application. Current Pain and Headache Reports 2 2, $234-241$

Quigley EM (2000): Pharmacotherapy of gastroparesis. Expert Opin Pharmacother $\underline{1}$, $881-887$

Raffael A (1988): Grundlagen der analytischen Durchflußzytometrie. Labor-Medizin 11, $89-97$

Rajegowda BK, Kandall SR, Falciglia H (1978): Sudden unexpected death in infants of narcotic-dependent mothers. Early Hum Dev 2, 219 - 225

Rauser L, Savage JE, Meltzer HY, Roth BL (2001): Inverse agonist actions of typical and atypical antipsychotic drugs at the human 5-hydroxytryptamine(2C) receptor. J Pharmacol Exp Ther 299, 83 - 89

Raymond JR, Mukhin YV, Gettys TW, Garnovskaya MN (1999): The recombinant 5HT1A receptor: $\mathrm{G}$ protein coupling and signalling pathways. $\mathrm{Br} \mathrm{J}$ Pharmacol $\underline{127}$, $1751-1764$

Rekling JC, Feldman JL (1998): PreBotzinger complex and pacemaker neurons: hypothesized site and kernel for respiratory rhythm generation. Annu Rev Physiol $\underline{60}$, $385-405$

Reynolds GP, Mason SL, Meldrum A, De Keczer S, Parnes H, Eglen RM, Wong EH (1995): 5-Hydroxytryptamine (5-HT)4 receptors in post mortem human brain tissue: distribution, pharmacology and effects of neurodegenerative diseases. $\mathrm{Br} \mathrm{J}$ Pharmacol 114, 993 - 998

Richter DW (1982): Generation and maintenance of the respiratory rhythm. J Exp Biol $\underline{100}, 93-107$

Richter DW: 'Neural Regulation of Respiration: Rhythmogenesis and Afferent Control'. Springer-Verlag, New York 1996

Richter DW, Spyer KM (2001): Studying rhythmogenesis of breathing: comparison of in vivo and in vitro models. Trends Neurosci $\underline{24}, 464-472$

Richter DW, Ballanyi K, Schwarzacher S (1992): Mechanisms of respiratory rhythm generation. Curr Opin Neurobiol 2, 788 - 793

Richter DW, Pierrefiche O, Lalley PM, Polder HR (1996): Voltage-clamp analysis of neurons within deep layers of the brain. J Neurosci Methods $\underline{67}, 121$ - 123

Richter DW, Lalley PM, Pierrefiche O, Haji A, Bischoff AM, Wilken B, Hanefeld F (1997): Intracellular signal pathways controlling respiratory neurons. Respir Physiol $\underline{110}, 113-123$

Richter DW, Schmidt-Garcon P, Pierrefiche O, Bischoff AM, Lalley PM (1999): Neurotransmitters and neuromodulators controlling the hypoxic respiratory response in anaesthetized cats. J Physiol $\underline{514}, 567$ - 578 
Richter DW, Mironov SL, Büsselberg D, Lalley PM, Bischoff AM, Wilken B (2000): Respiratory Rhythm Generation: Plasticity of a Neuronal Network. Neuroscientist $\underline{6}$, $181-198$

Richter DW, Manzke T, Wilken B, Ponimaskin E (2003): Serotonin receptors: guardians of stable breathing. Trends Mol Med $\underline{9}, 542$ - 548

Ringertz NR, Savage RE: 'Cell Hybrids`. Academic Press, New York 1976

Romberg R, Sarton E, Teppema L, Matthes HW, Kieffer BL, Dahan A (2003): Comparison of morphine-6-glucuronide and morphine on respiratory depressant and antinoci-ceptive responses in wild type and mu-opioid receptor deficient mice. $\mathrm{Br} \mathrm{J}$ Anaesth $\underline{91}, 862$ - 870

Ruat M, Traiffort E, Leurs R, Tardivel-Lacombe J, Diaz J, Arrang JM, Schwartz JC (1993): Molecular cloning, characterization, and localization of a high-affinity serotonin receptor (5-HT7) activating cAMP formation. Proc Natl Acad Sci $\underline{90}, 8547$ 8551

Saito H, Nishimura M, Shibuya E, Tsujino I, Miyamoto K, Kawakami Y (2002): Tissue hypoxia in sleep apnea syndrome assessed by uric acid and adenosine. Chest $\underline{122}$, 1686 - 1694

Sahibzada N, Ferreira M, Wasserman AM, Dretchen KL, Gillis RA (1999): 5-HT1A receptor activation reverses apnea induced by NMDA receptor blockade in the rat. Neurosci Abstr $\underline{25}, 378.2$.

Sahibzada N, Ferreira M, Wasserman AM, Taveira-DaSilva AM, Gillis RA (2000): Reversal of morphine-induced apnea in the anesthetized rat by drugs that activate 5hydroxytryptamine(1A) receptors. J Pharmacol Exp Ther 292, 704 - 713

Salinovich O, Montelaro RC (1986): Reversible staining and peptide mapping of proteins transferred to nitrocellulose after separation by sodium dodecylsulfatepolyacrylamide gel electrophoresis. Anal Biochem 156, 341 - 347

Scopes RK: 'Protein purification: Principles and practice`. Springer-Verlag, New York 1982

Sela M (1969): Antigenicity: some molecular aspects. Science $\underline{\underline{166}}, 1365$ - 1374

Shao Y, McCarthy KD (1994): Plasticity of astrocytes. Glia 11, 147 - 155

Shen Y, Monsma FJ, Metcalf MA, Jose PA, Hamblin MW, Sibley DR (1993): Molecular cloning and expression of a 5-hydroxytryptamine7 serotonin receptor subtype. J Biol Chem 268, 18200 - 18204

Shook JE, Watkins WD, Camporesi EM (1990): Differential roles of opioid receptors in respiration, respiratory disease, and opiate-induced respiratory depression. Am Rev Respir Dis 142, 895 - 909 
Smith JC, Greer JJ, Liu GS, Feldman JL (1990): Neural mechanisms generating respiratory pattern in mammalian brain stem-spinal cord in vitro. I. Spatiotemporal patterns of motor and medullary neuron activity. J Neurophysiol $\underline{64}, 1149$ - 1169

Smith JC, Ellenberger HH, Ballanyi K, Richter DW, Feldman JL (1991): Pre-Bötzinger complex: a brainstem region that may generate respiratory rhythm in mammals. Science 254, 726 - 729

Smith JC, Butera RJ, Koshiya N, Del Negro C, Wilson CG, Johnson SM (2000): Respiratory rhythm generation in neonatal and adult mammals: the hybrid pacemaker-network model. Respir Physiol 122, 131 - 47

Schwarzacher SW, Smith JC, Richter DW (1995): Pre-Bötzinger complex in the cat. J Neurophysiol $\underline{73}, 1452$ - 1461

Solomon IC, Edelman NH, Neubauer JA (1999): Patterns of phrenic motor output evoked by chemical stimulation of neurons located in the pre-Botzinger complex in vivo. J Neurophysiol $\underline{81}, 1150$ - 1161

Sora I, Takahashi N, Funada M, Ujike H, Revay RS, et al. (1997): Opiate receptor knockout mice define mu receptor roles in endogenous nociceptive responses and morphine-induced analgesia. Proc Natl Acad Sci 94, 1544 - 1549

Sprouse J, Reynolds L, Li X, Braselton J, Schmidt A (2004): 8-OH-DPAT as a 5-HT7 agonist: phase shifts of the circadian biological clock through increases in cAMP production. Neuropharmacology $\underline{46}, 52$ - 62

Takeda S, Eriksson LI, Yamamoto Y, Joensen H, Onimaru H, Lindahl SG (2001): Opioid action on respiratory neuron activity of the isolated respiratory network in newborn rats. Anesthesiology $\underline{95}, 740$ - 749

Taylor DP (1988): Buspirone, a new approach to the treatment of anxiety. FASEB J 2, $2445-2452$

Teng YD, Bingaman M, Taveira-DaSilva AM, Pace PP, Gillis RA, Wrathall JR (1999): Treatment with 5-HT1A receptor agonists reverses respiratory abnormalities in spinal cord injured rats. Neurosci Abstr $\underline{25}, 538.8$.

Thomas EA, Crayatt BF, Sutcliffe JG (1999): The endogenous lipid oleamide activates serotonin $5-\mathrm{HT} 7$ neurons in mouse thalamus and hypothalamus. J Neurochem $\underline{72}, 2370-2378$

Tijssen P: 'Practice and theory of enzyme immunoassays' (Laboratory techniques in biochemistry and molecular biology, Vol. 15). Elsevier, Amsterdam 1985

Tork I (1990): Anatomy of the serotonergic system. Ann N Y Acad Sci $\underline{600}, 9$ - 34

Tovey ER, Baldo BA (1989): Protein binding to nitrocellulose, nylon and PVDF membranes in immunoassays and electroblotting. J Biochem Biophys Methods $\underline{19}$, $169-183$ 
Towbin H, Gordon J (1984): Immunoblotting and dot immunobinding. Current status and out-look. J Immunol Methods $\underline{72}, 313$ - 340

Towbin H, Staehelin T, Gordon J (1979): Electrophoretic transfer of proteins from poly-acrylamide gels to nitrocellulose sheets: Procedure and some applications. Proc Natl Acad Sci $\underline{76}, 4350$ - 4354

Trulson ME, Arasteh K (1986): Buspirone decreases the activity of 5-hydroxytryptamine-containing dorsal raphe neurons in-vitro. J Pharm Pharmacol $\underline{38}, 380$ 382

Twarog BM, Page IH (1953): Serotonin content of some mammalian tissues and urine and a method for its determination. Am J Physiol 175, 157 - 161

Ullmer C, Engels P, Abdel'Al S, Lubbert H (1996): Distribution of 5-HT4 receptor mRNA in the rat brain. Naunyn Schmiedebergs Arch Pharmacol 354, 210 - 212

Van Aelst L, D'Souza-Schorey C (1997): Rho GTPases and signaling networks. Genes Dev 11, 2295 - 2322

Vanhoenacker P, Haegeman G, Leysen JE (2000): 5-HT7 receptors: current knowledge and future prospects. Trends Pharmacol Sci $\underline{21}, 70$ - 77

Varga V, Szekely AD, Csillag A, Sharp T, Hajós M (2001): Evidence for a role of GABA interneurones in the cortical modulation of midbrain 5-hydroxytryptamine neurones. Neuroscience 106, 783 - 792

Veasey SC, Fornal CA, Metzler CW, Jacobs BL (1995): Response of serotonergic caudal raphe neurons in relation to specific motor activities in freely moving cats. J Neurosci 15, 5346 - 5359

Verge D, Calas A (2000): Serotoninergic neurons and serotonin receptors: gains from cytochemical approaches. J Chem Neuroanat 18, 41 - 56

Vilaro MT, Cortes R, Gerald C, Branchek TA, Palacios JM, Mengod G (1996): Localization of 5-HT4 receptor mRNA in rat brain by in situ hybridization histochemistry. Brain Res Mol Brain Res $\underline{43}, 356$ - 360

Vizuete ML, Venero JL, Traiffort E, Vargas C, Machado A, Cano J (1997): Expression of $5-\mathrm{HT} 7$ receptor mRNA in rat brain during postnatal development. Neurosci Lett $\underline{227}, 53-56$

Waeber C, Sebben M, Grossman C, Javoy-Agid F, Bockaert J, Dumuis A (1993): [3H]-GR113808 labels 5-HT4 receptors in the human and guinea-pig brain. Neuroreport $\underline{4}, 1239-1242$

Waeber C, Sebben M, Nieoullon A, Bockaert J, Dumuis A (1994): Regional distribution and ontogeny of 5-HT4 binding sites in rodent brain. Neuropharmacology 33, $527-541$ 
Walter G, Scheidtmann KH, Carbone A, Laudano AP, Doolittle RF (1980): Antibodies specific for the carboxy- and amino-terminal regions of simian virus 40 large tumor antigen. Proc Natl Acad Sci 77, 5197 - 5200

Wang H, Stornetta RL, Rosin DL, Guyenet PG (2001): Neurokinin-1 receptorimmunoreactive neurons of the ventral respiratory group in the rat. $\mathrm{J}$ Comp Neurol 434, $128-46$

Weber K, Osborn M (1969): The reliability of molecular weight determinations by dodecyl sulfate-polyacrylamide gel electrophoresis. J Biol Chem 244, 4406 - 4412

Wilken B, Lalley P, Bischoff AM, Christen HJ, Behnke J, Hanefeld F, Richter DW (1997): Treatment of apneustic respiratory disturbance with a serotonin-receptor agonist. J Pediatr $\underline{130}, 89$ - 94

Williams DA, Thorn BE (1984): Opiate withdrawal behavior after focal brain stimulation. Pharmacol Biochem Behav 21, 699 - 703

Wolozin BL, Pasternak GW (1981): Classification of multiple morphine and enkephalin binding sites in the central nervous system. Proc Natl Acad Sci $\underline{78}, 6181$ 6185

Wright IK, Garratt JC, Marsden CA (1990): Effects of a selective 5-HT2 agonist, DOI, on 5-HT neuronal firing in the dorsal raphe nucleus and 5-HT release and metabolism in the frontal cortex. Br J Pharmacol $\underline{99}, 221$ - 222

Yaksh TL, Wilson PR (1979): Spinal serotonin terminal system mediates antinociception. J Pharmacol Exp Ther 208, 446 - 453

Yanisch-Perron C, Vieira J, Messing J (1985): Improved M13 phage cloning vectors and host strains: nucleotide sequences of the M13mp18 and pUC19 vectors. Gene $\underline{33}, 103-119$

Yeadon M, Kitchen I (1989): Opioids and respiration. Prog Neurobiol 33, 1 - 16

Yeadon M, Kitchen I (1990): Multiple opioid receptors mediate the respiratory depressant effects of fentanyl-like drugs in the rat. Gen Pharmacol 21, 655 - 664

Zgombick JM, Beck SG, Mahle CD, Craddock-Royal B, Maayani S (1989): Pertussis toxin-sensitive guanine nucleotide-binding protein(S) couple adenosine A1 and 5hydroxytryptamine1A receptors to the same effector systems in rat hippocampus: biochemical and electrophysiological studies. Mol Pharmacol 35, 484 - 494 


\section{Curriculum Vitae}

Address

Dept. of Neuro- and Sensory Physiology

University of Göttingen

Humboldtallee 23

37073 Göttingen

\section{Personal Data}

Date of Birth: 18. April 1964

Degree: Dr. med.
Phone: (0551) 395925

E-mail Address: tmanzke@gwdg.de

\section{Education}

$\begin{array}{ll}\text { Abitur } & 1988 \\ \text { Study } & 1988-1989 \\ & 1989-1996 \\ & 1996 \\ & 1994-1996 \\ & 2001-2004 \\ & 2002-2004\end{array}$

Walther-Lehmkuhl High School, Neumünster Philosophy, Univ. of Göttingen Human medicine, Univ. of Göttingen State examination at the Univ. of Göttingen Dissertation at the Univ. of Göttingen PhD student, Neuroscience, ENI, Göttingen Wissenschaftlicher Mitarbeiter/PostDoc; Dept. of Neurophysiology, Univ. of Göttingen

Teaching activity

$2001-2004$

2003
Neurophysiology courses for MD students in Göttingen (Praktikum, Seminar, Einführung)

Neurophysiology courses for Master students of the ENI

\section{Publications}

Manzke T, Günther U, Ponimaskin EG, Haller M, Dutschmann M, Schwarzacher S, Richter DW (2003): 5-HT4(a) Receptors avert opioid-induced breathing depression without loss of analgesia. Science $\underline{301}, 226$ - 229

Bickmeyer U, Heine M, Manzke T, Richter DW (2002): Differential modulation of $I_{h}$ by 5-HT receptors in mouse CA1 hippocampal neurons. Europ J Neurosci 16, 209 - 218

Richter DW, Manzke T, Wilken B, Ponimaskin E (2003): Serotonin receptors: guardians for stable breathing. Trends Mol Med $\underline{9}, 542$ - 548 
Manzke T, Preusse S, Hülsmann S, Rickmann M, Richter DW: Development of the serotonin $4(\mathrm{a})$ and $\mu$-opioid receptors in rodent preBötzinger complex. Submitted

Manzke T, Schlaf G, Demberg T, Richter DW: Hamster-mouse hetero-hybridoma producing specific anti-serotonin 7 receptor antibodies. Submitted

Günther U, Manzke T, Dutschmann M, Kettler D, Richter DW: 8-OH-DPAT prevents opioid-induced depression of respiratory activity without loss of analgesia. Submitted

\section{Lecture}

Conference lecture at the IXth Oxford conference on modelling and control of breathing: 'Serotonin 4(a) receptor is expressed in the Pre-Bötzinger complex of rat and defeats opioid-induced depression of respiratory activity without loss of analgesia'. Paris 2003, S29

\section{Acknowledgments}

The present thesis was carried out at the Department of Neuro- and Sensory Physiology in the Institute of Physiology of the University of Göttingen, Germany, under the supervision of Prof. Dr. Richter.

A special thank goes to Prof. Richter for the help and support he provided and for the freedom he offered me in my work.

I would also like to thank my colleagues and collaborators Dr. Schlaf, Dr. Demberg (Dept. of Immunology), Stefan Preusse (Dept. of Neuroanatomy), Dr. Günther (Dept. of Anaesthesiology), PD Dr. Quondamatteo (Dept. of Anatomy), PD Dr. Dutschmann, Dr. Hülsmann, PD Dr. Ponimaskin, Dr. Haller, Dr. Hess, and last but not least my little son Julian for his great emotional support. 